\title{
Schoolverlaters tussen onderwijs en arbeidsmarkt 2007
}

Citation for published version (APA):

Huijgen, T. G., Meng, C. M., \& Coenen, J. B. (2008). Schoolverlaters tussen onderwijs en arbeidsmarkt 2007. Researchcentrum voor Onderwijs en Arbeidsmarkt, Faculteit der Economische Wetenschappen. ROA Reports No. 3 https://doi.org/10.26481/umarep.2008003

Document status and date:

Published: 01/01/2008

DOI:

10.26481/umarep.2008003

Document Version:

Publisher's PDF, also known as Version of record

\section{Please check the document version of this publication:}

- A submitted manuscript is the version of the article upon submission and before peer-review. There can be important differences between the submitted version and the official published version of record.

People interested in the research are advised to contact the author for the final version of the publication, or visit the DOI to the publisher's website.

- The final author version and the galley proof are versions of the publication after peer review.

- The final published version features the final layout of the paper including the volume, issue and page numbers.

Link to publication

\footnotetext{
General rights rights.

- You may freely distribute the URL identifying the publication in the public portal. please follow below link for the End User Agreement:

www.umlib.nl/taverne-license

Take down policy

If you believe that this document breaches copyright please contact us at:

repository@maastrichtuniversity.nl

providing details and we will investigate your claim.
}

Copyright and moral rights for the publications made accessible in the public portal are retained by the authors and/or other copyright owners and it is a condition of accessing publications that users recognise and abide by the legal requirements associated with these

- Users may download and print one copy of any publication from the public portal for the purpose of private study or research.

- You may not further distribute the material or use it for any profit-making activity or commercial gain

If the publication is distributed under the terms of Article $25 \mathrm{fa}$ of the Dutch Copyright Act, indicated by the "Taverne" license above, 


\section{Schoolverlaters tussen onderwijs en arbeidsmarkt 2007}

ROA-R-2008/3

Researchcentrum voor Onderwijs en Arbeidsmarkt

Faculteit der Economische Wetenschappen en Bedrijfskunde

Universiteit Maastricht

Maastricht, september 2008 
Niets uit deze uitgave mag worden verveelvoudigd en/of openbaar gemaakt door middel van druk, fotokopie, microfilm, of op welke wijze ook, zonder voorafgaande schriftelijke toestemming van de directeur van het Researchcentrum voor Onderwijs en Arbeidsmarkt. In geval van overname van het datamateriaal moet telkens duidelijk als bron worden vermeld: "Researchcentrum voor Onderwijs en Arbeidsmarkt" of "ROA". Van publicaties waarin gebruik wordt gemaakt van gegevens uit dit rapport ontvangen wij gaarne een exemplaar.

Hoewel de grootst mogelijke zorg is besteed aan de inhoud van dit rapport, kan het ROA in generlei opzicht verantwoordelijkheid op zich nemen voor eventuele onvolledigheden of onjuistheden.

ISBN: 978-90-532I-465-7 


\section{Inhoud}

Bladzijde

Voorwoord I

Samenvatting

Summary IX

I Kwaliteit van gediplomeerde schoolverlaters: Een heuristisch kader I

2 Kwalificatie 5

3 Selectie II

4 Kwalificerende vervolgtrajecten 2I

$5 \quad$ Intrede op de arbeidsmarkt 33

6 Samenvattende totaalscores 53

7 Regionale mobiliteit 59

Bijlage $1:$ Enkele centrale begrippen $\quad 65$

Bijlage 2: Kwaliteitsaspecten 69

Bijlage 3 : Kernindicatoren 1996-2007 73

Statistische Bijlage

$\begin{array}{ll}\text { Tabellen naar opleidingssector } & 77\end{array}$ 


\section{Voorwoord}

Wat is de kwaliteit van de gediplomeerde schoolverlaters en wat gaan ze na hun opleiding doen? Hoe is de aansluiting met het vervolgonderwijs? Als ze naar de arbeidsmarkt gaan, hoe snel krijgen ze dan werk? En sluit dat werk dan ook aan op de gevolgde opleiding? Hoe tevreden zijn werkende schoolverlaters met hun functie en hoe schatten zij hun carrièreperspectieven in?

Sinds 199I voert het Researchcentrum voor Onderwijs en Arbeidsmarkt (ROA) van de Universiteit Maastricht in samenwerking met DESAN Research Solutions ${ }^{\mathrm{T}}$ enkele grootschalige onderzoeken uit onder recente schoolverlaters en pas afgestudeerden waarmee op dit soort vragen een antwoord kan worden gegeven. Het voorliggende rapport Schoolverlaters tussen onderwijs en arbeidsmarkt 2007 gaat in op de kwaliteit en de bestemming van gediplomeerde schoolverlaters en afgestudeerden van het school- of studiejaar 2005/2006. De resultaten die worden gepresenteerd zijn gebaseerd op het onderzoek dat eind 2007/begin 2008 over de volle breedte van het Nederlandse onderwijsstelsel is uitgevoerd en hebben betrekking op de situatie van schoolverlaters en afgestudeerden ongeveer anderhalf jaar na het voltooien van de opleiding. In totaal zijn circa I05.000 schoolverlaters en afgestudeerden benaderd. De totale respons bedroeg $36 \%{ }^{2}$ De verzamelde gegevens vormen samen het door het ROA ontwikkelde SchoolverlatersInformatieSysteem (SIS). Dit informatiesysteem is gebaseerd op een viertal grootschalige enquêtes die volgens een geïntegreerd model worden uitgevoerd.

Allereerst betreft het de VO-Monitor. Deze enquête is gericht op schoolverlaters van het algemeen voortgezet onderwijs (HAVO, VWO) en het voorbereidend beroepsonderwijs (VMBO). Vervolgens de BVE-Monitor, een enquête onder schoolverlaters van de beroepsopleidende (BOL) en beroepsbegeleidende leerweg (BBL) van het secundair beroepsonderwijs. Tot slot de HBO-Monitor en WO-Monitor. Dit zijn volledig vergelijkbare enquêtes gericht op afgestudeerden van het hoger beroepsonderwijs (HBO) en het wetenschappelijk onderwijs (WO). Ze worden uitgevoerd onder auspiciën van respectievelijk de HBO-raad en de Vereniging van Samenwerkende Nederlandse Universiteiten (VSNU).

De vier schoolverlatersonderzoeken hebben ieder een tweeledige doelstelling. In de eerste plaats fungeren ze als instrument voor kwaliteitszorg voor onderwijsinstellingen. Deelnemende onderwijsinstellingen ontvangen daartoe een uniek en vertrouwelijk instellingsrapport met de resultaten van hun 'eigen' schoolverlaters of afgestudeerden. In de desbetreffende rapporten worden deze resultaten direct vergeleken met het landelijke beeld voor de onderscheiden opleidingen. Deze instellingsrapporten worden gebruikt als instrument om de eigen opleiding te evalueren, bijvoorbeeld in het kader van een visitatie. Ook worden de

I. Het ROA heeft de algehele projectleiding en is specifiek verantwoordelijk voor de instrumentontwikkeling en de wetenschappelijke analyse en rapportage. DESAN Research Solutions is verantwoordelijk voor de dataverzameling en -verwerking, alsmede voor de specifieke rapporten voor de deelnemende onderwijsinstellingen.

2. Over de dataverzameling en -verwerking zal later dit jaar nog een apart werkdocument bij het ROA verschijnen. 
gegevens gebruikt om (aankomende) studenten voor te lichten over de verwachte beroepsperspectieven. De tweede doelstelling van de vier schoolverlatersonderzoeken betreft het genereren van een statistisch betrouwbare, landelijk representatieve databron over de transitie van school naar werk of vervolgonderwijs. Door het grootschalige karakter van de onderzoeken, en de goede onderlinge afstemming, vormen de huidige schoolverlatersonderzoeken VOMonitor, BVE-Monitor, HBO-Monitor en WO-Monitor de belangrijkste en meest gedetailleerde informatiebron over de bestemming van schoolverlaters in Nederland. ${ }^{3}$

Dit rapport richt zich vooral op degenen die zich in beleidsmatige zin bezig houden met de doorstroom van gediplomeerde schoolverlaters binnen het onderwijssysteem enerzijds en de arbeidsmarktpositie van gediplomeerde schoolverlaters anderzijds. Daarbij wordt met name gedacht aan de landelijke en regionale overheid, sociale partners, Centra voor Werk en Inkomen (CWI) en het (georganiseerde) onderwijsveld. De gegevens in dit rapport geven een beeld van de recente ontwikkelingen in het doorstroomgedrag en de arbeidsmarktpositie van gediplomeerde schoolverlaters.

Het rapport Schoolverlaters tussen onderwijs en arbeidsmarkt 2007 kent dit jaar een vernieuwde en tweedelige opzet:

Het voorliggende rapport toont de gegevens van de gediplomeerde schoolverlaters en afgestudeerden. Het omvat zowel de rapportage kwaliteit van de gediplomeerde schoolverlaters als de statistische bijlage, waarin de belangrijkste resultaten in tabelvorm zijn samengebracht.

In het najaar van 2008 verschijnt een tweede rapportage. In deze rapportage wordt uitgebreid ingegaan op de ongediplomeerde schoolverlaters van het VMBO, het AVO en het MBO. In deze rapportage staan we stil bij vragen zoals "wie zijn de ongediplomeerde schoolverlaters?”, "waarom zijn ze gestopt met hun opleiding?", "gestopt, wat nu?” en "wat zijn hun kansen op de arbeidsmarkt?".

Naast deze twee rapportages verschijnt nog een aantal afzonderlijke rapporten over de arbeidsmarktpositie van hoger opgeleiden. In de eerste plaats betreft dit de rapportage $D e$ arbeidsmarktpositie van afgestudeerden van het hoger beroepsonderwijs, HBO-Monitor 2007, die wordt uitgegeven door de HBO-raad. Hoewel de belangrijkste informatie van de afgestudeerden van het $\mathrm{HBO}$ ook in het voorliggende rapport is opgenomen, wordt voor meer gedetailleerde informatie verwezen naar dit afzonderlijke rapport. Hetzelfde geldt voor de tweejaarlijkse rapportage van de WO-Monitor, De arbeidsmarktpositie van afgestudeerden van de Nederlandse universiteiten, die door de VSNU zal worden uitgebracht. Hierin wordt verslag gedaan van de resultaten van meting 2006 en meting 2007.

De projectleiding van Schoolverlaters tussen onderwijs en arbeidsmarkt 2007 berust bij dr. C.M. Meng en Prof. dr. R.K.W. van der Velden. Het rapport is geschreven door drs. T.G. Huijgen, dr. C.M. Meng en drs. J.B. Coenen. De Statistische Bijlage is samengesteld door P.J.E.G van der Kolk en E.M.H.P. Soudant. De eindredactie is in handen van dr. C.M. Meng. Secretariële ondersteuning is verleend door M.H.J. Beenkens, J.M. Lebens

3. Voor meer informatie over de schoolverlatersonderzoeken wordt verwezen naar de websites www.vomonitor.nl, www.bvemonitor.nl, www.hbomonitor.nl en www.womonitor.nl. 
en M.M.J.L. Boere. Voornoemde personen zijn allen werkzaam bij het ROA. Aan SIS, waarop dit rapport is gebaseerd, werken verder mee dr. J.P. Allen, drs. G.W.M. Ramaekers (beiden werkzaam bij het ROA), drs. M.C.M.Th. van Alphen, drs. J.M.R. van Dongen en drs. B.M. Kinket (allen werkzaam bij DESAN Research Solutions). Bij het onderzoek onder schoolverlaters van de agrarische opleidingen is samengewerkt met IVA te Tilburg en KBA te Nijmegen. We bedanken dr. P.R. den Boer, dr. D.J.J.M. Nijman (beide thans werkzaam bij IVA), drs. A.K. Jager (thans werkzaam bij Kenniscentrum Beroepsonderwijs Arbeidsmarkt) voor de plezierige samenwerking. Een speciaal dankwoord is gericht aan ing. P. Dijkstra, N. Nijdam en drs. J.D. de Vries (allen werkzaam bij de Informatie Beheer Groep te Groningen) voor de medewerking bij het uitzetten van de steekproeven onder zowel de gediplomeerde als de ongediplomeerde schoolverlaters van het VMBO, het MBO en het AVO.

Een speciaal woord van dank wordt gericht aan de vertegenwoordigers van de financiers die in de klankbordgroep zitting hebben: drs. J.H. Donk en drs. R. Jongsma (beiden werkzaam bij het Ministerie van Sociale Zaken en Werkgelegenheid), ir. J.M.H.M. van Geffen en drs. U. Teunis (beiden werkzaam bij het Ministerie van Landbouw, Natuur en Voedselkwaliteit), drs. M. Hesseling, J.A. de Hoog, drs. P.M.C. Thoolen, drs. R.H.A. Tjoa, dr. L.H.J. van de Venne en drs. M. Warmerdam (allen werkzaam bij het Ministerie van Onderwijs, Cultuur en Wetenschap).

Maastricht, september 2008

Prof. dr. T.A. Dohmen

directeur 


\section{Samenvatting}

Het voorliggende rapport presenteert de resultaten van het onderzoek dat eind 2007/begin 2008 over bijna de volle breedte van het Nederlandse onderwijsstelsel heeft plaatsgevonden. In totaal zijn I05.000 gediplomeerde schoolverlaters en afgestudeerden van het schooljaar $2005 / 2006$ benaderd. De totale respons bedroeg $36 \%$.

De resultaten hebben betrekking op de situatie van schoolverlaters van VMBO, MBO-BOL, MBO-BBL, HAVO, VWO, en van afgestudeerden van $\mathrm{HBO}$ en WO ongeveer anderhalf jaar na het voltooien van de opleiding. In dit rapport worden uitsluitend gegevens gepresenteerd van gediplomeerde schoolverlaters en afgestudeerden van voltijdopleidingen.

\section{Kwaliteit van gediplomeerde schoolverlaters in 2007}

De kwaliteit van de gediplomeerde schoolverlaters en afgestudeerden is aan de hand van een vijftal aspecten gemeten, namelijk kwalificatie (de vraag of men voldoende competenties heeft verworven tijdens de opleiding), selectie (de vraag of de opleiding voldoende streng en betrouwbaar selecteert), allocatie (de aansluiting naar de vervolgbestemming), externe rendement (de opbrengsten) en tevredenheid achteraf. Bij de allocatie, het externe rendement en de tevredenheid achteraf is verder een onderscheid gemaakt tussen de antwoorden van schoolverlaters die zich op de arbeidsmarkt aanbieden en de antwoorden van schoolverlaters die verder gaan leren.

\section{Kwalificatie (hoe goed is men voorbereid op de arbeidsmarkt of het vervolgonderwijs?)}

Met betrekking tot de breedte van de gevolgde opleiding vindt $6 \%$ van alle schoolverlaters dat de opleiding te smal is. Een iets grotere groep, $9 \%$, vindt de opleiding juist te breed. Met name in het hoger onderwijs is men relatief vaak van mening dat de opleiding te breed is. Wat betreft de diepgang van de opleiding is een iets grotere groep, namelijk $15 \%$, van mening dat de opleiding meer diepgang had mogen hebben. Onder de $\mathrm{HBO}$ afgestudeerden is zelfs bijna een kwart van de afgestudeerden deze mening toegedaan. Van de gediplomeerde VMBO respondenten vindt II\% dat hun VMBO opleiding te weinig diepgang had.

Vier van de tien gediplomeerden vindt dat de opleiding een goede basis biedt om te starten op de arbeidsmarkt. Dit percentage stijgt naarmate het onderwijsniveau hoger wordt (van $24 \%$ voor het $\mathrm{VMBO}$ tot $60 \%$ voor het WO). Een meer langere termijn doelstelling van het onderwijs heeft betrekking op de vraag of de opleiding een goede basis vormt voor het verder ontwikkelen van kennis en vaardigheden. Hier is $58 \%$ van de respondenten het mee eens. Het meest tevreden zijn de afgestudeerden van het WO (83\%). 


\section{Selectie (hoe streng wordt er in de opleiding beoordeeld?)}

De bevraagde schoolverlaters zijn nogal kritisch wat betreft de selectie binnen de gevolgde opleiding. Zo is, evenals verleden jaar, $17 \%$ van alle schoolverlaters van mening dat de genoten opleiding te gemakkelijk was. Onder de schoolverlaters van het MBO-BOL niveau 4 is dit zelfs $26 \%$. Daarnaast heeft slechts $19 \%$ de docenten als streng ervaren, terwijl $40 \%$ van de schoolverlaters van mening is dat de docenten niet streng waren in de beoordeling van de studenten. Met uitzondering van de afgestudeerden van het WO vond verder minder dan $50 \%$ dat de opleiding uitdagend was qua niveau. Zo geeft van de afgestudeerden van het $\mathrm{HBO} 32 \%$ aan dat de opleiding uitdagend was, terwijl $37 \%$ het hiermee (helemaal) niet eens is. De opleidingen in de $\mathrm{HBO}$ sector onderwijs worden zelfs door minder dan één op de vier afgestudeerden als uitdagend gezien. In het MBO zijn het vooral de opleidingen op niveau I en 2 die door de schoolverlaters als uitdagend worden gezien.

Niet alleen worden de opleidingen zelden als uitdagend ervaren, maar ook de examens lijken niet pittig te zijn. Nog niet eens 30\% vindt dat de examens pittig waren, terwijl $36 \%$ de examens (helemaal) niet als pittig heeft ervaren. Tot slot is minder dan 50\% van de schoolverlaters van mening dat in de opleiding voldoende op inzicht werd getoetst. Opvallend is dat ook in het WO nog niet de helft $(48 \%)$ deze mening is toegedaan. Positieve uitschieter wat betreft het toetsen op inzicht is de WO sector natuurwetenschappen. Hier is 63\% van mening dat voldoende op inzicht werd getoetst.

\section{Allocatie (waar komt men terecht?)}

Bijna negen van de tien schoolverlaters van het voortgezet onderwijs stroomt door naar een vervolgopleiding. Van de BOL respondenten gaat een kleine $42 \%$ verder met een andere studie. De respondenten van de BBL en het hoger onderwijs zijn duidelijk meer gericht op de arbeidsmarkt. ${ }^{4}$

Van de verder lerende schoolverlaters gaat bijna 60\% verder met een studie die wat betreft richting in het verlengde ligt van de gevolgde opleiding. De BBL-ers kiezen het vaakst voor een vervolgstudie in dezelfde onderwijssector. Bijna driekwart van de verder lerende uitstroom vindt de aansluiting tussen de gevolgde en de vervolgopleiding redelijk tot goed. Met name de VMBO-ers zijn hierover te spreken.

Van de werkende gediplomeerden heeft iets meer dan driekwart een baan op minimaal het eigen opleidingsniveau. Binnen het $\mathrm{MBO}$ is er wel een verschil tussen de korte en lange opleidingen, hoe lager het onderwijsniveau, hoe minder vaak men op minimaal het eigen niveau werkzaam is. Bijna zeven van de tien gediplomeerde schoolverlaters heeft een baan in eigen of verwante richting. Met name $\mathrm{HBO}$ afgestudeerden hebben relatief vaak een baan binnen het eigen beroependomein.

4. De cijfers met betrekking tot 'verder leren' wijken vooral bij de schoolverlaters van de opleidingen op MBO niveau I,2 en 3 nogal af van de cijfers zoals gepresenteerd in de publicatie 'Kerncijfers 2003-2007' van het Ministerie van Onderwijs. De reden hiervoor is dat de respons onder de schoolverlaters die binnen het MBO doorstromen naar een hoger opleidingsniveau duidelijk lager ligt dan de respons onder de schoolverlaters die zich op de arbeidsmarkt aanbieden. De cijfers in Tabel S.I dienen met betrekking tot de indicator 'verder leren' daarom gelezen te worden als \% respondenten. 
$63 \%$ van de schoolverlaters geeft aan dat de kennis en vaardigheden in voldoende tot sterke mate benut worden terwijl één op de tien werkenden het gevoel heeft dat zijn of haar kennis en vaardigheden tekort schieten voor de functie die ze hebben. Zo'n driekwart is tevreden over de aansluiting tussen de gevolgde opleiding en de huidige functie, $68 \%$ geeft daarnaast aan tevreden te zijn met deze functie.

Tabel S.1

Enkele kernindicatoren per onderwijssoort

\begin{tabular}{|c|c|c|c|c|c|c|c|}
\hline & \multirow{2}{*}{$\begin{array}{c}\text { Verder leren } \\
\%\end{array}$} & Werkloosheid & \multirow{2}{*}{$\begin{array}{c}\text { Flexibele } \\
\text { aanstelling } \\
\%\end{array}$} & \multirow{2}{*}{$\begin{array}{c}\text { Bruto uurloon } \\
€\end{array}$} & \multirow{2}{*}{$\begin{array}{c}\text { Minimaal } \\
\text { eigen niveau } \\
\%\end{array}$} & \multirow{2}{*}{$\begin{array}{c}\text { Eigen/verwante } \\
\text { richting } \\
\%\end{array}$} & \multirow{2}{*}{$\begin{array}{c}\text { Zelfde opleiding } \\
\text { \% }\end{array}$} \\
\hline & & $\%$ & & & & & \\
\hline AV0 & 88 & 19 & 65 & 6,40 & $x$ & $x$ & 96 \\
\hline VMBO & 89 & 6 & 56 & 4,85 & 60 & 48 & 84 \\
\hline BOL 1 & 23 & 10 & 72 & 7,85 & 60 & 37 & 61 \\
\hline BOL 2 & 32 & 8 & 46 & 7,60 & 64 & 50 & 64 \\
\hline $\mathrm{BOL} 3$ & 27 & 4 & 44 & 9,45 & 79 & 73 & 75 \\
\hline BOL 4 & 55 & 3 & 40 & 10,10 & 84 & 76 & 80 \\
\hline BBL 1 & 10 & 5 & 16 & 9,00 & 46 & 52 & 61 \\
\hline BBL 2 & 19 & 3 & 27 & 9,80 & 64 & 65 & 74 \\
\hline BBL 3 & 13 & 0 & 18 & 11,40 & 68 & 79 & 81 \\
\hline BBL 4 & 15 & 2 & 14 & 12,65 & 87 & 84 & 80 \\
\hline HBO & 35 & 3 & 39 & 13,10 & 85 & 82 & 80 \\
\hline wo & 32 & 3 & 46 & 15,60 & 64 & 74 & 83 \\
\hline Totaal & 58 & 4 & 40 & 10,70 & 75 & 69 & 83 \\
\hline$x$ & & $=$ & vra & niet opgeno & & & \\
\hline Verder & & . & & $\begin{array}{l}\text { Dondenten o } \\
\text { ervolg opleic }\end{array}$ & $\begin{array}{l}\text { in aansluiti } \\
\text { g (incl. dual }\end{array}$ & $\begin{array}{l}\text { op de gevolg } \\
\text { pleidingen) is }\end{array}$ & $\begin{array}{l}\text { de opleiding } \\
\text { gaan volgen. }\end{array}$ \\
\hline Werklc & heid & $=$ & $\begin{array}{l}\text { wer } \\
\text { arb }\end{array}$ & $\begin{array}{l}\text { oekenden al } \\
\text { Ismarkt aank }\end{array}$ & $\begin{array}{l}\text { van de sch } \\
\text { den. }\end{array}$ & olverlaters die & zich op de \\
\hline Flexib & anstelling & $=$ & $\begin{array}{l}\% \text { V } \\
\text { uitz }\end{array}$ & $\begin{array}{l}\text { de werkeno } \\
\text { dkracht, opr }\end{array}$ & $\begin{array}{l}\text { choolverlat } \\
\text { pkracht e.d }\end{array}$ & $\begin{array}{l}\text { met een aan } \\
\text { f een tijdelijke }\end{array}$ & $\begin{array}{l}\text { stelling als } \\
\text { aanstelling. }\end{array}$ \\
\hline Bruto & oon & $=$ & $\begin{array}{l}\text { Bru } \\
\text { exc }\end{array}$ & $\begin{array}{l}\text { uurloon in d } \\
\text { ief inkomen }\end{array}$ & $\begin{array}{l}\text { oofdfuncti } \\
\text { overwerk. }\end{array}$ & $\begin{array}{l}\text { clusief toesla } \\
\text { rloon afgeror }\end{array}$ & $\begin{array}{l}\text { gen maar } \\
\text { d op } 5 \text { cent. }\end{array}$ \\
\hline Minim & eigen niveau & $=$ & $\begin{array}{l}\text { \% v } \\
\text { gev } \\
\text { onc }\end{array}$ & $\begin{array}{l}\text { de werkend } \\
\text { voor deze fu } \\
\text { wijsniveau e }\end{array}$ & $\begin{array}{l}\text { choolverlat } \\
\text { ie minimaa }\end{array}$ & $\begin{array}{l}\text { en dat aangeef } \\
\text { en diploma va }\end{array}$ & $\begin{array}{l}\text { dat de werk- } \\
\text { n het gevolgde }\end{array}$ \\
\hline Eigen/ & wante richting & 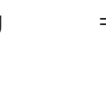 & $\begin{array}{l}\text { \% v } \\
\text { gev } \\
\text { opl }\end{array}$ & $\begin{array}{l}\text { de werkend } \\
\text { voor deze fu } \\
\text { lingsrichting }\end{array}$ & $\begin{array}{l}\text { choolverlat } \\
\text { tie een dipl } \\
\text { een verwar }\end{array}$ & $\begin{array}{l}\text { dat aangeef } \\
\text { ha van de gev } \\
\text { opleidingsric }\end{array}$ & $\begin{array}{l}\text { dat de werk- } \\
\text { olgde } \\
\text { hting eist. }\end{array}$ \\
\hline Zelfde & eiding & $=$ & $\begin{array}{l}\% v \\
\text { dez }\end{array}$ & $\begin{array}{l}\text { de schoolve } \\
\text { de opleiding }\end{array}$ & $\begin{array}{l}\text { ters dat aar } \\
\text { onieuw te } z\end{array}$ & $\begin{array}{l}\text { eft, achteraf } \\
\text { en kiezen. }\end{array}$ & ezien, \\
\hline
\end{tabular}

\section{Externe rendement (wat levert het op?)}

Van de schoolverlaters richt zo'n 56\% zich na het behalen van het diploma op de arbeidsmarkt. De gemiddelde werkloosheid bedraagt $4 \%$, en $7 \%$ van de gediplomeerden is direct na het behalen van het diploma vier maanden of langer werkloos. Deze intredewerkloosheid is het hoogst onder afgestudeerden van het hoger onderwijs. Vier van de tien werkende school- 
verlaters hebben een flexibele aanstelling, een even grote groep heeft een deeltijdaanstelling. Iets meer dan de helft vindt dat de functie waarin ze werkzaam zijn veel tot zeer veel carrièremogelijkheden biedt.

Van alle verder lerende gediplomeerden stopt zo'n II\% voortijdig met de vervolgopleiding. Ongeveer 7-\% punt hiervan bestaat uit studiewisselaars, de andere 4\%-punt kiest een ander traject, bijvoorbeeld de arbeidsmarkt. Studenten die voor een HBO opleiding kiezen als vervolgstudie houden er het vaakst mee op.

\section{Tevredenheid achteraf}

Van alle werkzame respondenten zou $78 \%$ de gevolgde opleiding opnieuw gaan volgen. Van de verder lerende respondenten is dit $87 \%$. De minste spijt is er bij de $\mathrm{HBO}$ en WO afgestudeerden. Binnen het MBO hebben de schoolverlaters van de langere, niveau 3 en 4 opleidingen minder spijt dan hun studiegenoten van de kortere MBO trajecten.

\section{Regionale mobiliteit}

Uit de schoolverlatersdata blijkt dat zowel het $\mathrm{MBO}$ als het $\mathrm{HBO}$ een belangrijke leverancier van nieuwe arbeidskrachten voor met name de regionale arbeidsmarkt is. De grote meerderheid van de jongeren die een $\mathrm{MBO}$ of $\mathrm{HBO}$ opleiding gaan volgen doen dit in dezelfde provincie als waar ze op hun $15 / \mathrm{I} 6 \mathrm{e}$ woonden en blijven daarna ook in dezelfde provincie wonen en werken. Slechts een klein percentage verhuist om elders een opleiding te gaan volgen. Wel blijft van hen een meerderheid daarna in dezelfde provincie wonen en werken als waar ze de opleiding gevolgd hebben. 


\section{Summary}

This report contains the main results of a survey which was conducted in late 2007 and early 2008 across almost the full range of the Dutch education system. A total of 105,000 secondary and tertiary education school-leavers who graduated in the school year 2005/2006 were approached. The overall response rate was $36 \%$.

The report describes the situation of graduates of pre-vocational secondary professional education (in Dutch voorbereidend middelbaar beroepsonderwijs or VMBO), senior secondary vocational education (both vocational training (in Dutch beroepsopleidende leerweg or BOL) and block or day-release training (in Dutch beroepsbegeleidende leerweg or BBL)), general secondary education (in Dutch algemeen voortgezet onderwijs (AVO); this includes both senior general secondary education (in Dutch hoger algemeen voortgezet onderwijs or HAVO) and pre-university education (in Dutch voorbereidend wetenschappelijk onderwijs or VWO)), higher professional education (in Dutch hoger beroepsonderwijs or $\mathrm{HBO}$ ) and university education (in Dutch wetenschappelijk onderwijs or WO). The graduates were approached approximately a year and a half after completing education. This report only contains results pertaining to graduates of full-time secondary and tertiary education programs.

\section{Quality of graduates in 2007}

The quality of the secondary and tertiary education graduates has been assessed on five main dimensions, namely qualification (whether one has acquired sufficient knowledge and skills during education), selection (whether the degree or diploma is a reliable indicator of one's quality), allocation (whether one ends up in the right job or further education), returns to education (whether one is rewarded for one's investment) and satisfaction. For allocation, returns to education and satisfaction, a further distinction is drawn between school leavers who entered the labour market and school leavers who proceeded to further education.

\section{Qualification (how well did the program prepare graduates for work or further education?)}

$6 \%$ of all school leavers reported that they felt that their program was too narrow in its focus, while a slightly larger group, $9 \%$, found their program too broad. Higher education graduates were particularly likely to report that their education was too broad. $15 \%$ of all school leavers would have preferred more depth in their program. This applied to almost a quarter of HBO graduates, compared to II\% of VMBO graduates.

Four out of ten graduates felt that their program offered a good basis to start in the labour market. This percentage increases with educational level, from $24 \%$ for VMBO graduates to $60 \%$ for university graduates. Looking more at the longer term, $58 \%$ of graduates reported that their program formed a good basis for further developing knowledge and skills. University graduates were most satisfied in this respect $(83 \%)$. 


\section{Selection (how strict is the assessment in the program?)}

School leavers are rather critical in terms of the strictness of selection in their program. $17 \%$ of all school leavers reported that that they found their program too easy. This applied most to MBO-BOL school leavers at level 4 (26\%). Only $19 \%$ reported that their teachers were strict in assigning grades, while $40 \%$ reported that the teachers were hardly strict at all. Less than $50 \%$ of graduates (with the exception of university graduates) experienced the program as challenging. $32 \%$ of $\mathrm{HBO}$ graduates found their program challenging, while $37 \%$ found their program hardly challenging at all. Less than one in four graduates of $\mathrm{HBO}$ teacher training found their program challenging. Of the $\mathrm{MBO}$ programs, those at levels I and 2 were most likely to be experienced as challenging.

Not only did graduates rarely experience their programs as challenging, but they rarely found their examinations difficult. Less than $30 \%$ regarded their examinations as very difficult, and $36 \%$ did not find them difficult at all. Less than $50 \%$ of graduates reported that insight was sufficiently tested in their program. This even applies to almost half $(48 \%)$ of the university graduates. The natural sciences formed an exception to this rule: $63 \%$ of university graduates in this sector reported that their insight was sufficiently tested in their program.

\section{Allocation (where do graduates end up?)}

Almost nine out of ten general secondary school leavers continues on to further education, and almost $42 \%$ of BOL graduates carry on with further studies. BBL and higher education are clearly more targeted towards the labour market. ${ }^{5}$

Of the graduates who continue on to further education, almost $60 \%$ choose a field directly related to that of the program from which they graduated. BBL graduates most often choose a program in the same educational sector. Almost three-quarters of those who continue on to further education report a satisfactory or good match between the program they graduated from and the subsequent program. VMBO graduates are particularly satisfied with this match.

Slightly more than three quarters of graduates who enter the labour market after graduation find work requiring at least their own level of education. Within MBO there is a clear contrast between short and long programs in this respect: the lower the level, the less likely one is to find work requiring at least that level. Almost seven out of ten graduates has found a job requiring their own or a related field. This applies particularly to $\mathrm{HBO}$ graduates.

$63 \%$ of graduates report that their knowledge and skills are utilized to a sufficient or high extent, while one in ten working graduates report that their knowledge and skills are not up to the standard for the job they have. Around three-quarters of the working graduates are

5. The figures concerning 'further education' differ substantially from those presented in the Ministry of Education's publication 'Kerncijfers 2003-2007', especially for graduates of MBO levels I,2 en 3. The reason for this is that the response rate among $\mathrm{MBO}$ graduates who continue on to a higher level of education is significantly lower than that among MBO graduates who enter the labour market. The figures in Table S.I should therefore be read as the percentage of respondents proceeding to further education. 
satisfied with the match between their education and their work, and $68 \%$ are satisfied with their job.

\section{Table S.1}

Selected key indicators per type of education

\begin{tabular}{|c|c|c|c|c|c|c|c|}
\hline & $\begin{array}{l}\text { Further } \\
\text { education }\end{array}$ & Unemployment & Flexible contract & $\begin{array}{l}\text { Gross hourly } \\
\text { wage }\end{array}$ & $\begin{array}{l}\text { At least own } \\
\text { level }\end{array}$ & $\begin{array}{l}\text { Own or } \\
\text { related field }\end{array}$ & $\begin{array}{l}\text { Same } \\
\text { program }\end{array}$ \\
\hline & $\%$ & $\%$ & $\%$ & $€$ & $\%$ & $\%$ & $\%$ \\
\hline AVO & 88 & 19 & 65 & 6.40 & $x$ & $x$ & 96 \\
\hline VMBO & 89 & 6 & 56 & 4.85 & 60 & 48 & 84 \\
\hline BOL 1 & 23 & 10 & 72 & 7.85 & 60 & 37 & 61 \\
\hline BOL 2 & 32 & 8 & 46 & 7.60 & 64 & 50 & 64 \\
\hline BOL 3 & 27 & 4 & 44 & 9.45 & 79 & 73 & 75 \\
\hline BOL 4 & 55 & 3 & 40 & 10.10 & 84 & 76 & 80 \\
\hline BBL 1 & 10 & 5 & 16 & 9.00 & 46 & 52 & 61 \\
\hline BBL 2 & 19 & 3 & 27 & 9.80 & 64 & 65 & 74 \\
\hline BBL 3 & 13 & 0 & 18 & 11.40 & 68 & 79 & 81 \\
\hline BBL 4 & 15 & 2 & 14 & 12.65 & 87 & 84 & 80 \\
\hline $\mathrm{HBO}$ & 35 & 3 & 39 & 13.10 & 85 & 82 & 80 \\
\hline wo & 32 & 3 & 46 & 15.60 & 64 & 74 & 83 \\
\hline Totaal & 58 & 4 & 40 & 10.70 & 75 & 69 & 83 \\
\hline$x$ & & \multicolumn{6}{|c|}{$=$ question not included. } \\
\hline \multicolumn{2}{|c|}{ Further education } & \multicolumn{6}{|c|}{$\begin{array}{l}=\% \text { respondent who have continued on to further education after graduation } \\
\text { (incl. dual programs). }\end{array}$} \\
\hline \multicolumn{2}{|c|}{ Unemployment } & \multicolumn{6}{|c|}{$\begin{array}{l}=\% \text { of graduates who entered the labour market who were looking for work at the } \\
\text { moment of the survey. }\end{array}$} \\
\hline \multicolumn{2}{|c|}{ Flexible contract } & \multicolumn{6}{|c|}{$\begin{array}{l}=\% \text { of working graduates who are working via a temporary employment agency } \\
\text { or who have a temporary contract. }\end{array}$} \\
\hline \multicolumn{2}{|c|}{ Gross hourly wage } & \multicolumn{6}{|c|}{$\begin{array}{l}=\text { Gross hourly wage in the main job, including bonuses but excluding income from } \\
\text { overtime. Hourly wage rounded to nearest } 5 \text { cents. }\end{array}$} \\
\hline \multicolumn{2}{|c|}{ At least own level } & \multicolumn{6}{|c|}{$\begin{aligned}= & \% \text { of working graduates who reported that the employer required their own or a } \\
& \text { higher level of education for the job. }\end{aligned}$} \\
\hline \multicolumn{2}{|c|}{ Own/related field } & \multicolumn{6}{|c|}{$\begin{array}{l}=\% \text { of working graduates who reported that the employer required their own or a } \\
\text { related field for the job. }\end{array}$} \\
\hline \multicolumn{2}{|c|}{ Same program } & \multicolumn{6}{|c|}{$\begin{array}{l}=\% \text { of graduates who reported that, if they were free to choose again, they would } \\
\text { choose the same program. }\end{array}$} \\
\hline
\end{tabular}

\section{Returns to education (what is the investment worth?)}

Around $56 \%$ of school leavers enter the labour market after graduation. The average unemployment among school leavers amounts to $4 \%$, and $7 \%$ of graduates are unemployed for four months or longer after graduation. The job search duration is longest among higher education graduates. Four out of ten working graduates have flexible contracts, and about the same proportion work part-time. Slightly more than half report that their job offers good career prospects. 
II\% of the graduates who continued to further education have dropped out within the first one to two years, without obtaining a degree or diploma. Most of these - approximately 7 percentage points - consist of people who have switched to a different program. The remaining 4 percentage points leave education for another destination, for example the labour market. Graduates who continue on to further education in HBO are most likely to drop out prematurely.

\section{Satisfaction}

Looking back, $78 \%$ of graduates who entered the labour market report that they would choose the same program if they could choose again. For those who continued to further education this proportion is $87 \%$. $\mathrm{HBO}$ and university graduates are least likely to regret their study choice. Within MBO graduates of the longer programs (levels 3 and 4) are more often satisfied with their chosen program the graduates of the the shorter $\mathrm{MBO}$ programs.

\section{Regional mobility}

The data clearly show that both $\mathrm{MBO}$ and $\mathrm{HBO}$ are important suppliers of new workers, especially for the regional labour market. A large majority of young people who follow an $\mathrm{MBO}$ or $\mathrm{HBO}$ program do so in the province where they lived at age 16 and remain living and working in the same province after graduation. Only a small proportion enroll at an educational institute in a different province. Of those who do move, a majority remain living and working in that province after graduation. 


\section{Kwaliteit van gediplomeerde schoolverlaters: Een heuristisch kader}

In deze rapportage wordt ingegaan op de kwaliteit van de gediplomeerde schoolverlaters. ${ }^{6}$ Dit gebeurt aan de hand van enkele indicatoren die behoren bij het heuristisch kader dat gebruikt wordt om de kwaliteit van (het gerealiseerde niveau van) onderwijs te beoordelen. Deze kwaliteit kan vanuit twee invalshoeken beoordeeld worden: op basis van doeltreffendheid en op basis van doelmatigheid (Onderwijsraad, 1999; zie ook Ramaekers \& Van der Velden, 2006).7 Doeltreffendheid zegt iets over de mate waarin het onderwijs de haar toegeschreven functies vervult. Deze functies kunnen op verschillende gebieden liggen. In de schoolverlatersonderzoeken en in dit rapport beperken we ons echter tot de doeltreffendheid met betrekking tot de doorstroom naar het vervolgonderwijs en de doorstroom naar de arbeidsmarkt. Doelmatigheid wordt gedefinieerd als de mate van kostenefficiëntie waarmee het onderwijs de functies vervult die zijn omschreven.

Voor de beoordeling van de doeltreffendheid van het onderwijs wordt gekeken naar een drietal verschillende functies te weten: de kwalificatiefunctie, de selectiefunctie en de allocatiefunctie (Peschar \& Wesselingh, 200I). ${ }^{8}$

\section{Kwalificatiefunctie}

Bij de kwalificatiefunctie van het onderwijs gaat het om de vraag in hoeverre het onderwijs erin geslaagd is de schoolverlaters afdoende toe te rusten met de competenties die relevant zijn voor de doorstroming naar een vervolgopleiding of de arbeidsmarkt. Daarbij gaat het niet enkel om de startbekwaamheid van de schoolverlaters (de korte termijn doelstelling van het onderwijs), maar ook om de mate waarin de opleiding een voldoende basis heeft geboden voor de verdere ontwikkeling van 'novice' tot 'expert' (ontwikkelpotentieel) en voor de mate waarin de opleiding heeft bijgedragen aan de algehele 'employability' van de schoolverlater (de lange termijn doelstelling).

6. Gediplomeerde schoolverlaters worden in deze rapportage gedefinieerd als schoolverlaters die in het schooljaar $2005 / 2006$ hun diploma behaald hebben. Hierbij speelt het geen rol of dit diploma het predicaat "startkwalificatie" in de zin van een diploma op minimaal MBO niveau 2 heeft of niet.

7. Onderwijsraad (1999), Schoolkwaliteit in beeld, Den Haag: Onderwijsraad.

Ramaekers, G \& Velden, R. van der (2006), The proof of the pudding is in the eating: hoe onderzoek onder afgestudeerden gebruikt kan worden voor de accreditatie van opleidingen, Tijdschrift voor Hoger Onderwijs, 24/I, pp. 2-I2.

8. Peschar, J. \& A. Wesselingh (200I), Onderwijssociologie, Groningen: Wolters-Noordhoff. 


\section{Selectiefunctie}

De betrouwbaarheid waarmee het onderwijs studenten beoordeelt op de aanwezige competenties en op grond hiervan een eindniveau certificeert is van groot belang. De legitimering van de kwalificatiefunctie van het onderwijs is namelijk voor een groot deel gelegen in deze betrouwbaarheid. Om een indicatie van de selectie in het onderwijs te krijgen, is aan de schoolverlaters een aantal stellingen voorgelegd. Zo zijn ze gevraagd hun oordeel te geven met betrekking tot (I) de moeilijkheidsgraad van de opleiding, (2) de beoordeling van de scholieren/studenten door de leraren, (3) de mate waarin de opleiding uitdagend was qua niveau, (4) de zwaarte van de examens en (5) het toetsen op inzicht. De antwoorden op deze stellingen geven een beeld van het oordeel van de schoolverlaters met betrekking tot de selectie in het onderwijs.

\section{Allocatiefunctie}

De allocatiefunctie van het onderwijs richt zich enerzijds op de vraag of het onderwijs de afgestudeerden voldoende heeft voorgelicht over de mogelijkheden in het vervolgonderwijs en de arbeidsmarkt na het verlaten van de studie (de ondersteuning bij de transitie van opleiding naar vervolgstudie en/of de arbeidsmarkt). Anderzijds richt de allocatiefunctie zich op de vraag in hoeverre de gekozen vervolgstudie, dan wel de gevonden baan, aansluit bij de gevolgde opleiding.

Behalve naar de doeltreffendheid van de genoemde drie functies kan ook naar de doelmatigheid worden gekeken. Vanuit deze tweede invalshoek gaat het bij de kwalificatiefunctie om het leerrendement (de verhouding van groei in kennis en de instructiekosten). Vanwege het vrijwel ontbreken van empirische gegevens met betrekking tot dit aspect zal dit leerrendement in deze rapportage echter buiten beschouwing worden gelaten. Ook wordt niet nader ingegaan op de doelmatigheid van de selectiefunctie, het interne rendement, omdat onderwijsinstellingen zelf hier al systematisch gegevens over verzamelen. Wel wordt gekeken naar de doelmatigheid van de derde functie, de allocatiefunctie. Het gaat hierbij om het externe rendement.

\section{Externe rendement}

Het externe rendement van onderwijs kan worden gedefinieerd als de verhouding tussen kosten en opbrengsten die door individuen en de overheid gerealiseerd worden. Dit rendement is met name van belang bij de vaststelling van de macrodoelmatigheid van opleidingen. In dit rapport beperken we ons tot het externe rendement op individueel niveau. We meten daarbij de (korte termijn) opbrengsten van opleidingen op de arbeidsmarkt aan de hand van een drietal indicatoren: (I) het werkloosheidspercentage I I/2 jaar na het verlaten van de opleiding, (2) het bruto uurloon I I/2 jaar na het verlaten van de opleiding en (3) de carrièremogelijkheden van de gevonden baan. Wat het externe rendement betreft voor schoolverlaters die naar een vervolgopleiding doorstromen, kijken we (I) naar het percentage van hen dat in de eerste anderhalf jaar alweer gestopt of van studie gewisseld is en (2) naar het percentage van hen dat bevorderd is naar het tweede/ leer- of studiejaar. 


\section{Tevredenheid achteraf}

Met name voor onderwijsinstellingen is het van belang te weten in welke mate de gediplomeerde uitstroom achteraf weer voor dezelfde opleiding en dezelfde school zou kiezen. Afgestudeerden wordt derhalve altijd de vraag voorgelegd of ze achteraf gezien opnieuw dezelfde opleiding zouden kiezen. Hoewel formeel geen onderdeel van de beoordeling van de doeltreffendheid van het onderwijs, geeft deze zogenaamde spijtvraag een indicatie van de tevredenheid van de schoolverlater over de gevolgde opleiding.

In dit rapport wordt met name op al deze aspecten ingegaan. Daarnaast, wordt bij de regionale mobiliteit van de schoolverlaters en afgestudeerden stilgestaan. We analyseren onder andere in hoeverre schoolverlaters voor hun studie naar een andere provincie verhuizen, in hoeverre ze na het behalen van het diploma weer terugkeren en waar ze werken.

Het rapport is als volgt opgebouwd. In hoofdstuk 2 wordt op basis van een aantal indicatoren de kwalificatiefunctie van het onderwijs in kaart gebracht. In hoofdstuk 3 staat de selectiefunctie centraal. In hoofdstuk 4 wordt nader ingegaan op schoolverlaters die een kwalificerend vervolgtraject volgen. Hierbij wordt achtereenvolgens op de aspecten allocatie, rendement en tevredenheid achteraf ingegaan. In hoofdstuk 5 staan we stil bij de schoolverlaters die zich na het behalen van het diploma op de arbeidsmarkt aangeboden hebben. Ook hier komen weer de aspecten allocatie, rendement en tevredenheid achteraf aan de orde. In hoofdstuk 6 geven we een samenvattend beeld wat betreft de kwaliteit van de schoolverlaters. Hierbij wordt voor elke onderscheiden opleidingssector voor zover mogelijk voor de verschillende kwaliteitsaspecten een totaalscore gepresenteerd. Ten slotte wordt in hoofdstuk 7 de regionale mobiliteit van de schoolverlaters in kaart gebracht.

In de figuren in dit hoofdstuk worden de niveau I opleidingen van het MBO niet naar sector gespecificeerd. Dit vanwege de vaak te geringe aantallen per opleidingssector op dit niveau. Voor alle figuren geldt verder dat cijfers slechts gepresenteerd worden indien zij op de antwoorden van een voldoende aantal respondenten gebaseerd zijn. 


\section{Kwalificatie}

Voor een goede doorstroming naar het vervolgonderwijs of de arbeidsmarkt is voor een schoolverlater het beschikken over voldoende competenties van groot belang. De kwalificatiefunctie van onderwijs gaat in op de vraag in hoeverre schoolverlaters tijdens hun opleiding de voor deze doorstroom relevante competenties hebben opgedaan. Voor schoolverlaters die naar de arbeidsmarkt doorstromen, is hierbij niet alleen de vraag relevant of de opleiding hen startbekwaam heeft gemaakt (de korte termijn doelstelling van het onderwijs), maar ook of de opleiding een goede basis is voor de verdere ontwikkeling van 'novice' tot 'expert' (ontwikkelpotentieel) en voor de algehele 'employability' van de schoolverlaters (de lange termijn doelstelling).

Om een beeld te krijgen in hoeverre het onderwijs de schoolverlaters voldoende heeft voorbereid op een vervolgstudie of een intrede op de arbeidsmarkt, is hen gevraagd de afgeronde opleiding te beoordelen op een viertal aspecten: (I) de breedte van de opleiding (te smal <--> te breed), (2) de diepgang van de opleiding (te weinig diepgang <--> te veel diepgang), (3) de mate waarin de opleiding een goede basis biedt om te starten op de arbeidsmarkt en (4) de mate waarin de opleiding een goede basis biedt om kennis en vaardigheden verder te ontwikkelen. Daarbij geeft item (3) een inschatting van het oordeel van de schoolverlaters over een korte termijn doelstelling van het onderwijs en item (4) over een lange termijn doelstelling.

Figuur 2.I laat per onderwijssoort het percentage van de schoolverlaters zien dat hun gevolgde opleiding te smal of te breed vindt. Over alle onderwijssoorten geeft $6 \%$ van de schoolverlaters aan de gevolgde opleiding te smal te vinden. Een iets grotere groep (Iо\%) vindt de opleiding juist te breed. Met name in het hoger onderwijs is men relatief vaak van mening dat de opleiding te breed is. In het $\mathrm{HBO}$ is bijna één op de vijf afgestudeerden deze mening toegedaan, in de sector $\mathrm{HBO}$ economie is dit zelfs één op de vier afgestudeerden. Van de schoolverlaters uit zowel de BOL als de BBL vindt $8 \%$ de opleiding te breed, binnen de BBL zijn er wel grotere verschillen tussen de sectoren dan in de BOL. Zo vindt $24 \%$ van de schoolverlaters met een BBL niveau 4 gezondheidszorg opleiding de opleiding te breed, van de technisch opgeleiden op ditzelfde niveau is slechts $\mathrm{I} \%$ van de BBL-ers deze mening toegedaan. De BBL uitstroom vindt iets minder vaak dan de BOL uitstroom dat de opleiding te smal is, $6 \%$ versus $9 \%$. Voor de BOL geldt dat met name de schoolverlaters van de sector landbouw vinden dat hun opleiding te smal is. 
Figuur 2.1

Oordeel gediplomeerde schoolverlaters: Breedte van opleiding

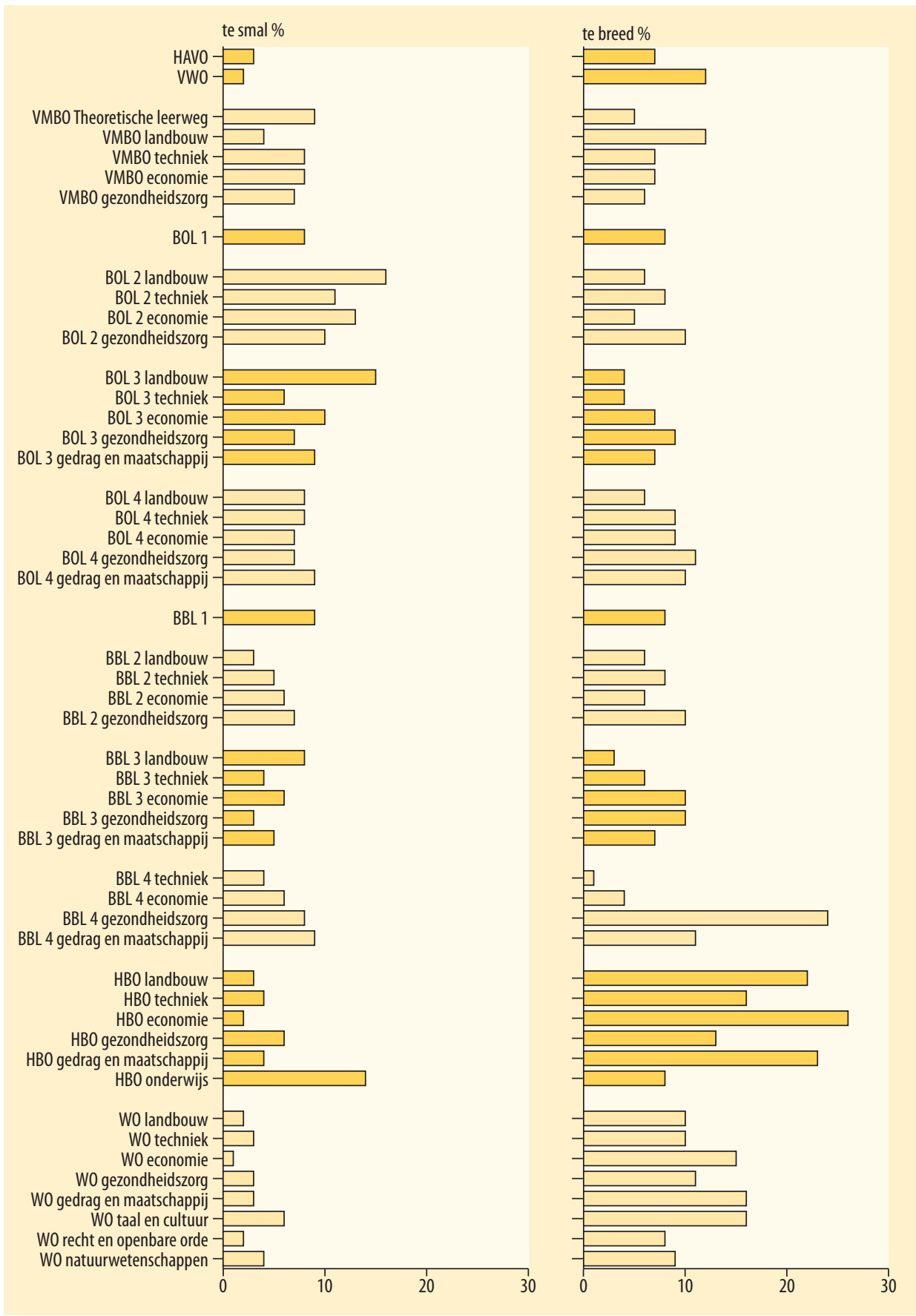

Zie ook Tabel A3.1 in de statistische bijlage. 
Figuur $\mathbf{2 . 2}$

Oordeel gediplomeerde schoolverlaters: Diepgang van opleiding

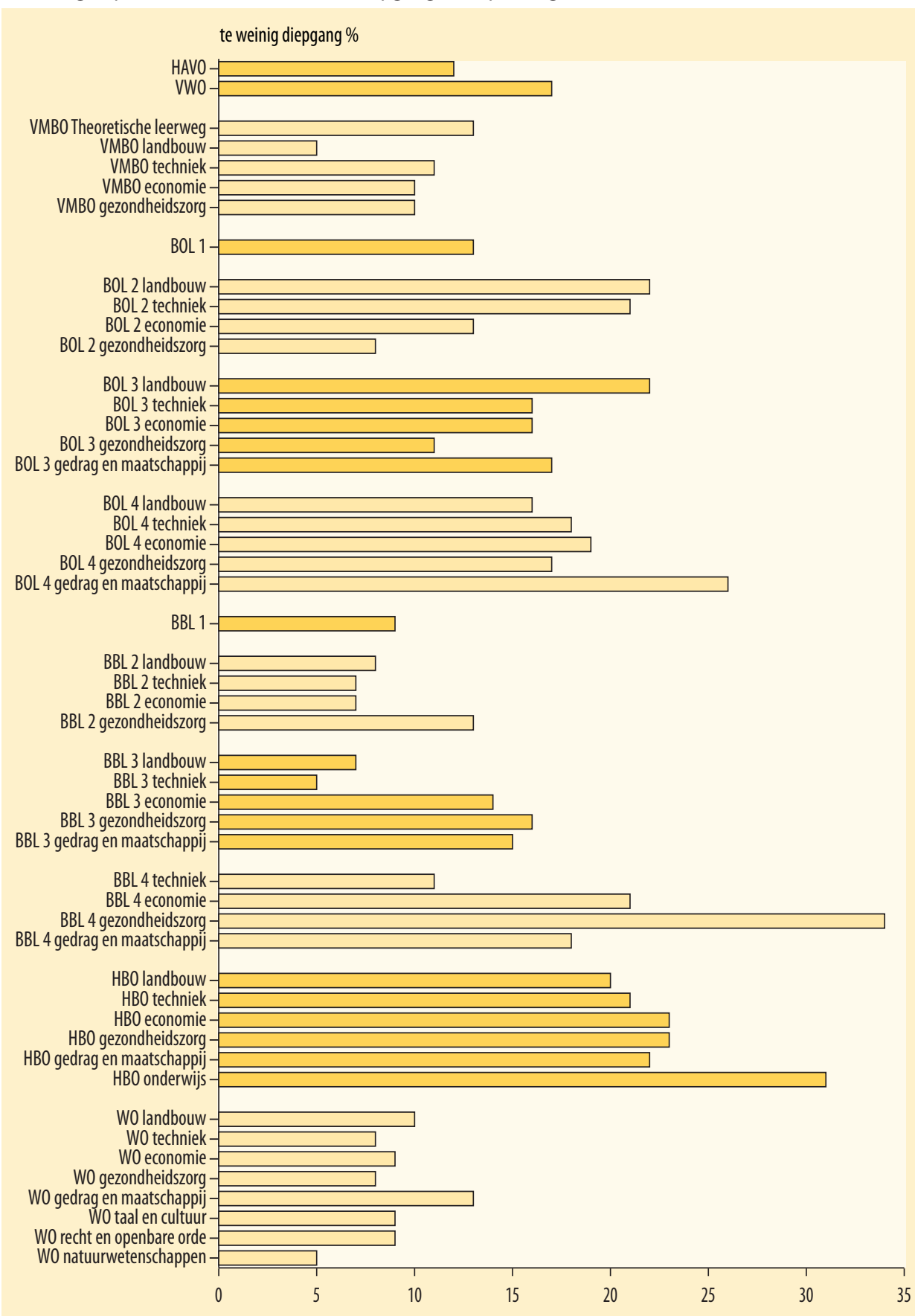

Zie ook Tabel A3.2 in de statistische bijlage. 
Een tweede belangrijke kwaliteitsindicator binnen de kwalificatiefunctie heeft betrekking op de diepgang van de opleiding. De schoolverlaters is dan ook gevraagd om behalve op breedte hun opleiding ook te waarderen op diepgang. In figuur 2.2 staan hiervan de resultaten. Gemiddeld vindt I4\% dat de gevolgde opleiding wat meer diepgang had mogen hebben. Met name de $\mathrm{HBO}$ afgestudeerden, bijna een kwart, zijn deze mening toegedaan. De uitstroom uit de lerarenopleidingen scoort het hoogst met $31 \%$. De BBL schoolverlaters zijn minder ontevreden met de diepgang van hun studie dan hun studiegenoten met een BOL achtergrond ( $12 \%$ respectievelijk $17 \%$ ). Opvallend binnen de BBL is wel dat de ontevredenheid over de diepgang op BBL niveau 4 groot is, behalve voor de sector techniek. Dit is vergelijkbaar met hun oordeel over de breedte van de opleiding. Binnen de BOL zijn de schoolverlaters uit de sectoren niveau 2 landbouw (22\%), niveau 2 techniek (2I\%), niveau 3 landbouw (22\%) en niveau 4 gedrag en maatschappij $(26 \%)$ ook relatief vaak ontevreden over de diepgang van hun gevolgde opleiding.

In tegenstelling tot verleden meetjaar is de vraag met betrekking tot diepgang van de opleiding ook voorgelegd aan de VMBO schoolverlaters. Van hen vindt II\% dat de opleiding te weinig diepgang heeft (en slechts $4 \%$ dat er te veel diepgang is). Dit ligt iets lager dan het landelijk gemiddelde. Met uitzondering van de VMBO landbouw sector zijn de onderlinge verschillen tussen de verschillende $\mathrm{VMBO}$ sectoren klein. Vanwege het meer algemene karakter van de VMBO-tl en de VMBO-gl is men hier het vaakst van mening dat de opleiding te weinig diepgang heeft. ${ }^{9}$

Een van de doelstellingen van het onderwijs is het voor de arbeidsmarkt startbekwaam maken van leerlingen. Figuur 2.3 geeft een indicatie van in hoeverre men hierin geslaagd is. Gemiddeld vindt $44 \%$ van de totale gediplomeerde uitstroom dat de opleiding een goede basis was om te starten op de arbeidsmarkt. Dit percentage stijgt naarmate het onderwijsniveau hoger wordt, van $24 \%$ voor het VMBO naar $60 \%$ voor het WO. Over de gehele linie is men iets tevredener over dit aspect dan het afgelopen meetjaar. Dat dit percentage voor het VMBO het laagst ligt is logisch aangezien een $\mathrm{VMBO}$ diploma niet gezien wordt als een startkwalificatie en als zodanig ook niet bedoeld is om de arbeidsmarkt mee te betreden. Alhoewel de niveau I opleidingen in het MBO dit ook niet zijn scoren ze wat dit aspect betreft toch iets hoger dan het $\mathrm{VMBO}$. Behalve op niveau I vinden de BBL schoolverlaters op alle niveaus iets vaker dan de BOL schoolverlaters dat de opleiding een goede start biedt hetgeen mogelijk veroorzaakt wordt door het leer/werk karakter van de beroepsbegeleidende leerweg. Opvallend is verder de hoge score van de BBL niveau 3 gezondheidszorg opleidingen, drie van de vier gediplomeerde uitstromers vindt de opleiding een goede basis voor de arbeidsmarktintrede.

9. Cijfers voor de verschillende leerwegen in het VMBO worden met uitzondering van de cijfers voor de theoretische leerweg niet in de figuren gepresenteerd. Ze zijn wel in de tabellen in de statistische bijlage aan het eind van dit rapport opgenomen. 


\section{Figuur 2.3}

Oordeel gediplomeerde schoolverlaters: Opleiding biedt goede basis om te starten op arbeidsmarkt en om kennis en vaardigheden verder te ontwikkelen

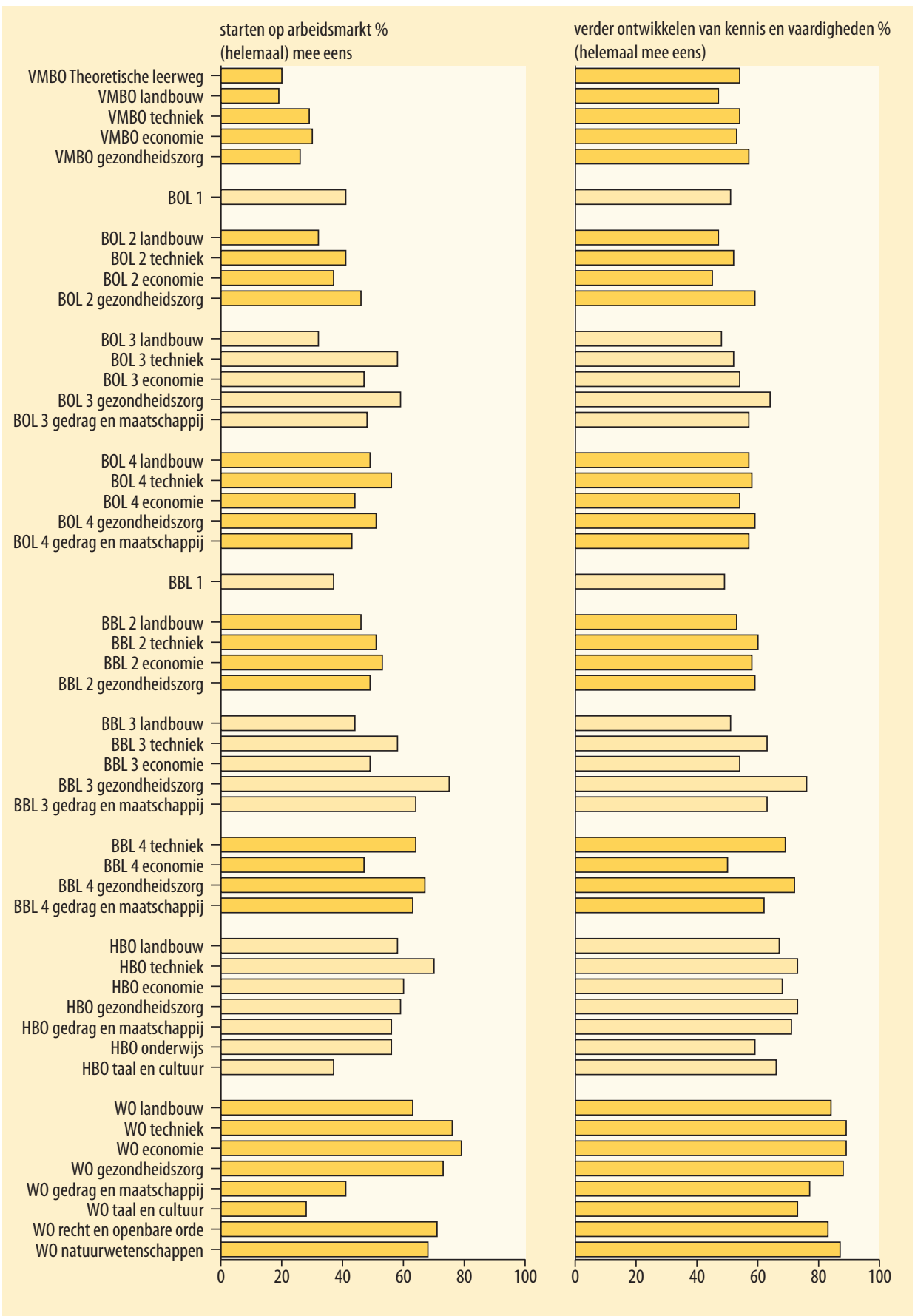

Zie ook Tabel A3.3 en Tabel A3.4 in de statistische bijlage. 
Een succesvolle arbeidsmarktintrede zegt iets over de korte termijn doelstelling van het onderwijs. Op langere termijn is het van belang in welke mate de genoten opleiding een goede basis is om kennis en vaardigheden verder te blijven ontwikkelen. Uit het tweede deel van figuur 2.3 blijkt dat over het gehele onderwijsveld 6I\% van de schoolverlaters vindt dat de gevolgde opleiding een goede basis vormt om kennis en vaardigheden verder te ontwikkelen (meetjaar 2006: 60\%). WO afgestudeerden scoren met $83 \%$ het hoogst, voor zowel de BOL-als de $\mathrm{VMBO}$ uitstroom geldt dit in $54 \%$ van de gevallen. Onder de BBL schoolverlaters is dit iets vaker het geval $(6 \mathrm{I} \%)$. Binnen het VMBO zijn er tussen de sectoren onderling relatief kleine verschillen, dit geldt eveneens voor het $\mathrm{HBO}$ en het WO. BBL-ers met een economische opleiding op niveau I vinden het minst vaak dat hun opleiding een goede basis gelegd heeft voor verdere ontwikkeling. Voor zowel BOL als BBL niveaus 3 en 4 geldt dat schoolverlaters met een gezondheidszorg opleidingsachtergrond hun verder ontwikkelmogelijkheden hoog inschatten ten opzichte van de andere sectoren van dezelfde onderwijssoort. 


\section{Selectie}

Zoals eerder is vermeld, is de betrouwbaarheid waarmee het onderwijs op competenties selecteert van wezenlijk belang. Over deze betrouwbaarheid van de selectie zijn maar weinig directe gegevens beschikbaar. De in dit hoofdstuk gepresenteerde indicatoren kunnen gezien worden als indicaties voor de betrouwbaarheid van de selectie. Om een beeld van de selectie binnen het onderwijs te geven, is aan de schoolverlaters gevraagd om over de volgende vijf aspecten hun oordeel te geven (I) de moeilijkheidsgraad van de opleiding, (2) de strengheid van de docenten bij het beoordelen van cursisten/studenten, (3) de mate waarin de opleiding uitdagend was qua niveau, (4) de mate waarin de examens als pittig werden ervaren (5) de mate waarin op inzicht werd getoetst.

Figuur 3.4 geeft het percentage schoolverlaters weer dat vindt dat de opleiding te makkelijk was. Evenals verleden meetjaar vindt gemiddeld $17 \%$ van alle schoolverlaters dat de opleiding te makkelijk was, slechts $4 \%$ vindt de opleiding te moeilijk. Van alle onderwijssoorten vinden met name de BOL schoolverlaters (22\%) en de HBO afgestudeerden (21\%) dat de opleiding wel wat moeilijker had mogen zijn. Van de afgestudeerden van de HBO sector onderwijs vindt zelfs $28 \%$ dat de opleiding te makkelijk was. In vergelijking met het $\mathrm{HBO}$ liggen de percentages in het WO relatief laag. Tussen de $7 \%$ (WO-sectoren techniek en natuurwetenschappen) en de $13 \%$ (WO sector gedrag en maatschappij) van de WO afgestudeerden vindt dat de opleiding te makkelijk was. Binnen het VMBO zijn het met name (één op de vijf) de gediplomeerde schoolverlaters van de theoretische leerweg die de moeilijkheidsgraad te laag vinden. Voor zowel BOL als BBL geldt dat relatief veel schoolverlaters met een opleiding uit de sector gedrag en maatschappij de genoten opleiding te makkelijk vinden. Dit geldt voor zowel de niveau 3 als de niveau 4 opleidingen. Wel moet er hier op geattendeerd worden dat het antwoorden van gediplomeerde schoolverlaters betreft, en dat cursisten die de opleiding niet gehaald hebben buiten beschouwing zijn gelaten. $\mathrm{Zij}$ zullen ongetwijfeld een ander oordeel vellen over de moeilijkheidsgraad van de opleiding. 


\section{Figuur 3.4}

Oordeel gediplomeerde schoolverlaters: Moeilijkheidsgraad van opleiding

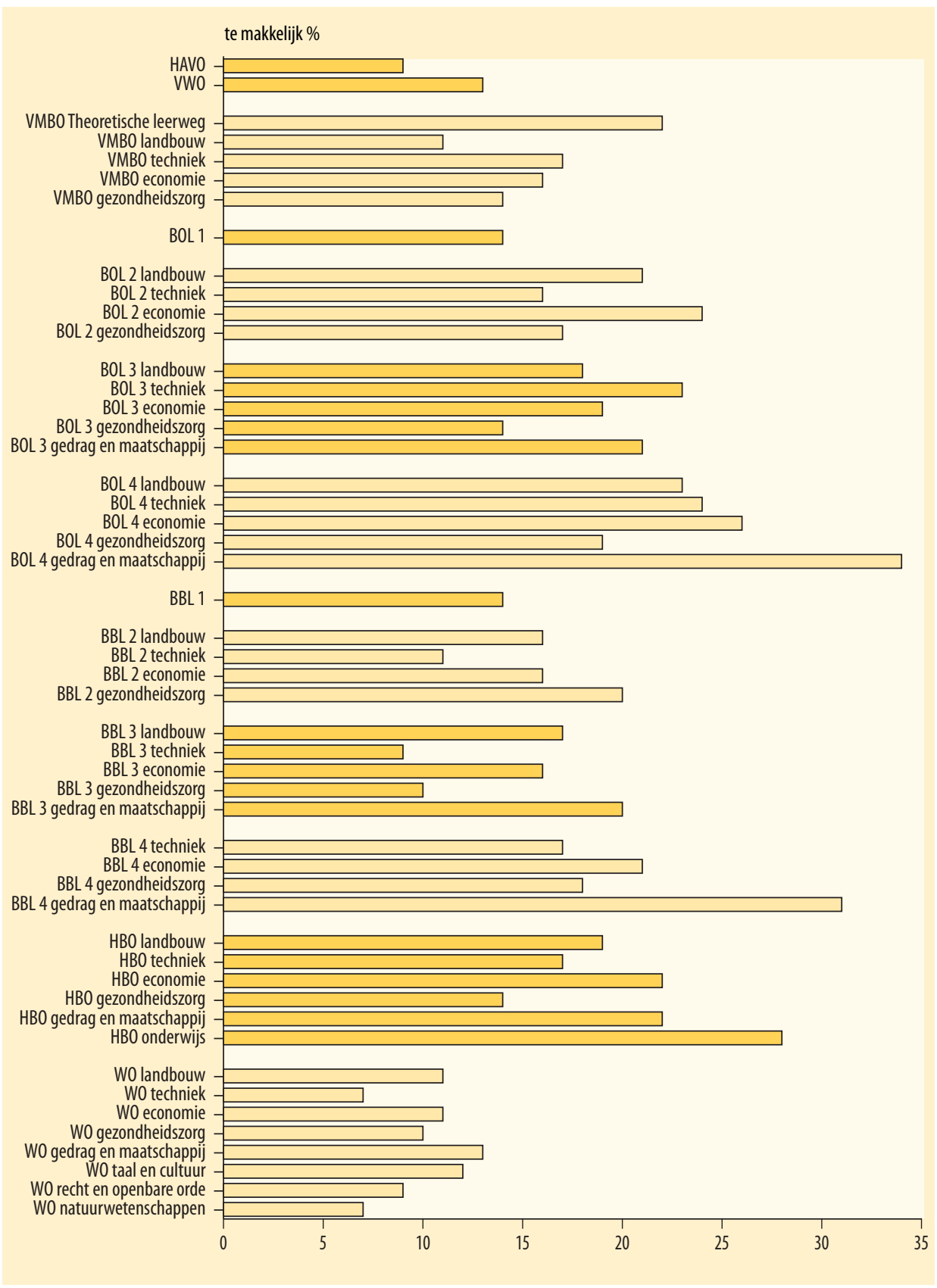

\section{Zie ook Tabel A4.1 in de statistische bijlage.}

Het tweede aspect wat betreft de betrouwbaarheid van het selectieproces van het onderwijs is de beoordeling van de studenten door docenten. Aan de schoolverlaters is de volgende stel- 
ling voorgelegd: 'de docenten waren streng in de beoordeling van studenten'. Figuur 3.5 laat het percentage zien dat het met deze stelling (helemaal) eens is. ${ }^{10}$

\section{Figuur 3.5}

Oordeel gediplomeerde schoolverlaters: Docenten waren streng in beoordeling van cursisten/studenten

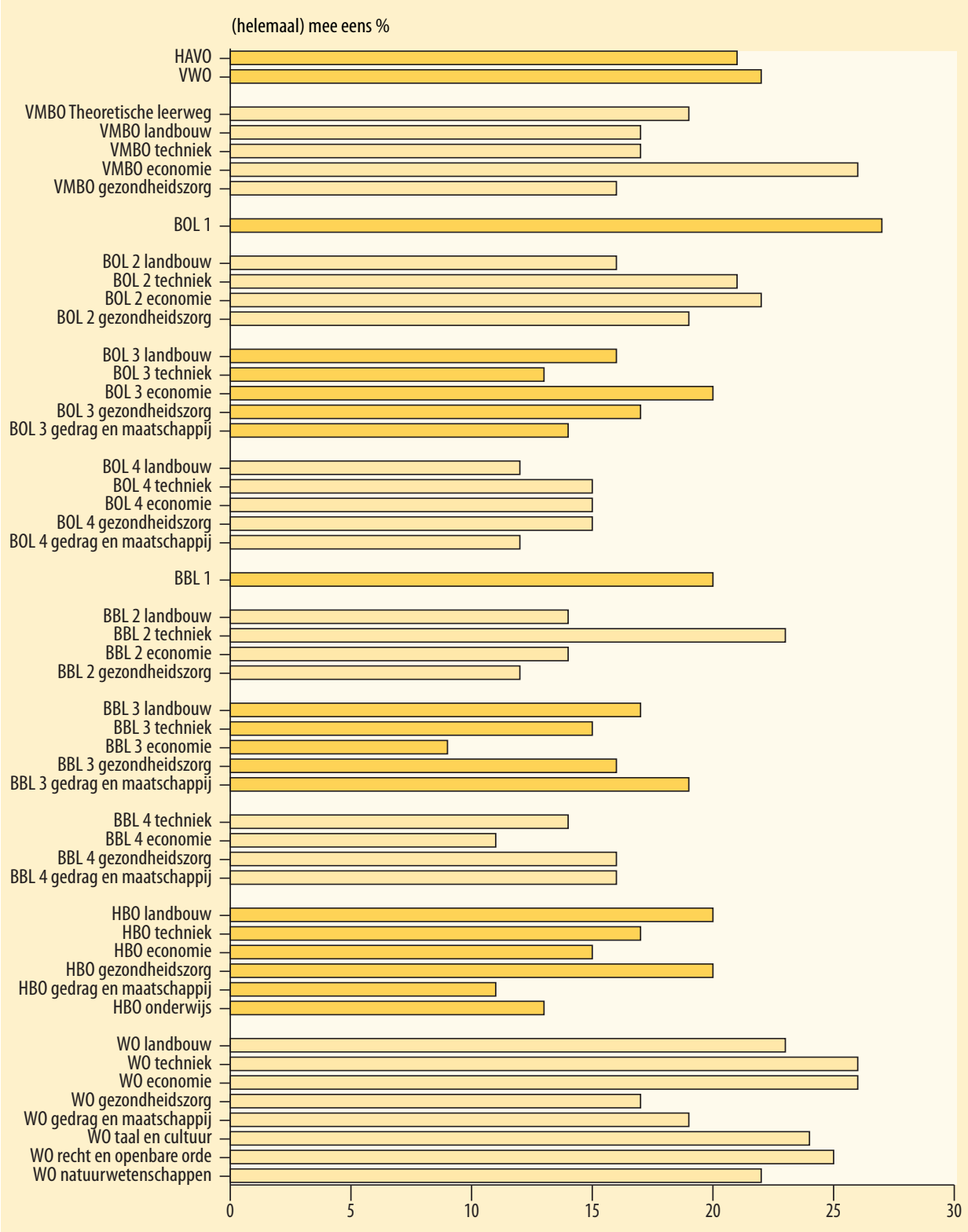

Zie ook Tabel A4.2 in de statistische bijlage.

Io. Tabel A4.2 van de statistische bijlage laat ook het percentage zien dat het (helemaal) oneens is met deze stelling. 


\section{Figuur 3.6}

Oordeel gediplomeerde schoolverlaters: Opleiding heeft uitdagend niveau

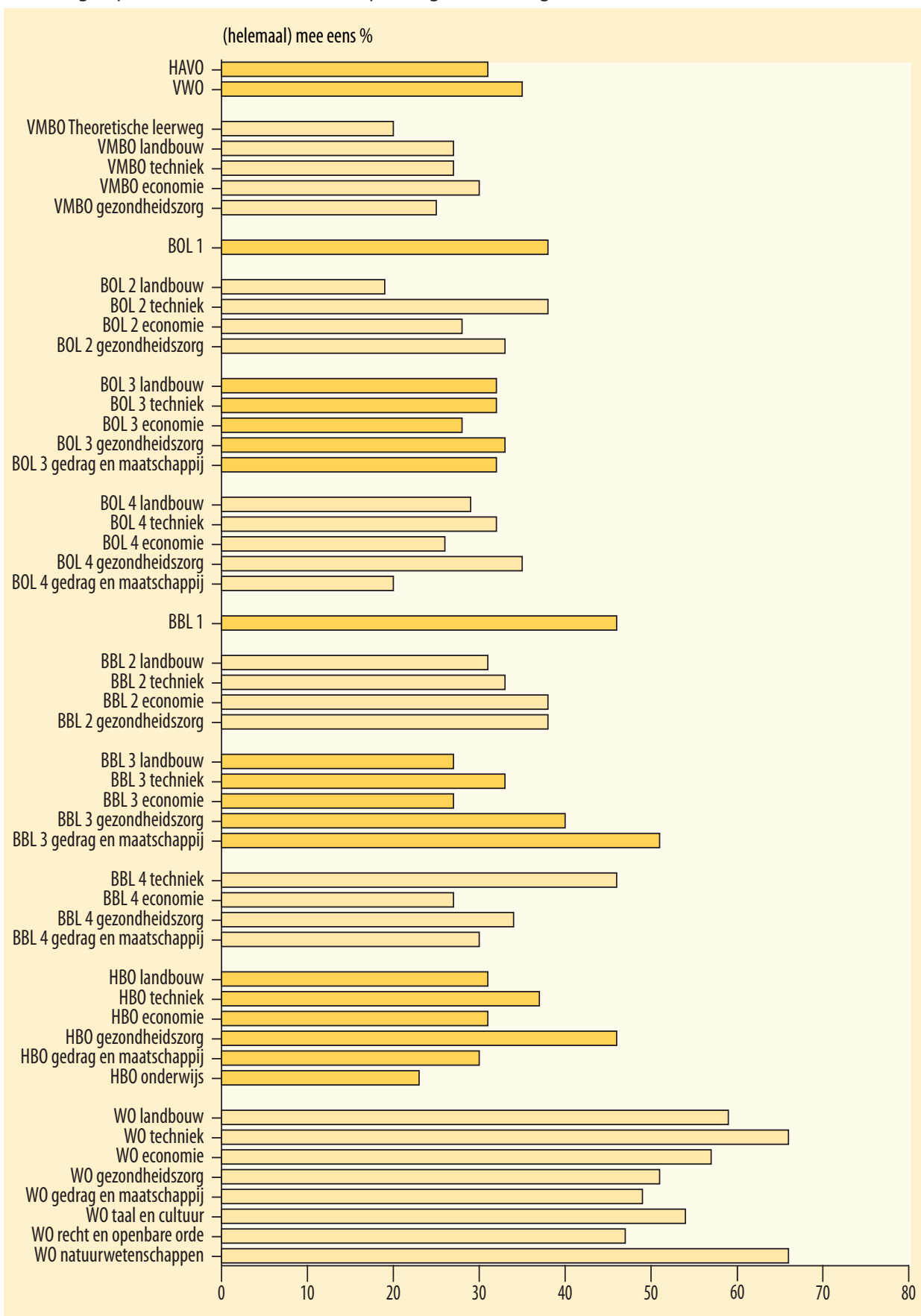

Zie ook Tabel A4.3 in de statistische bijlage. 
Van de gediplomeerde schoolverlaters is slechts $19 \%$ het eens met deze stelling. Tegelijkertijd is $40 \%$ het (helemaal) niet eens met deze stelling. Dit is vergelijkbaar met de cijfers van het afgelopen meetjaar. De gemiddelden van de verschillende onderwijssoorten liggen niet ver uit elkaar. Tussen de $16 \%$ (MBO-BBL) en $22 \%$ (WO) van de schoolverlaters vindt dat de docenten de studenten streng beoordeelden. Aan de andere kant vindt tussen de 35\% (AVO) en $46 \%$ (HBO) (helemaal) niet dat de docenten streng beoordeelden. Op VMBO niveau zijn het met name de schoolverlaters met een economische opleiding die vinden dat de docenten streng waren in hun beoordeling van de leerlingen. Maar ook hier is 'slechts' $26 \%$ het (zeer) met de stelling eens. Bij zowel de $\mathrm{BOL}$ als de $\mathrm{BBL}$ is er een verschil tussen de lagere niveau opleidingen (niveau I en 2) en de hogere niveau opleidingen (niveau 3 en 4). Hoe lager het niveau van de gevolgde opleiding is, hoe vaker men vindt dat de docenten streng waren in hun beoordeling. Bij de BOL ligt het percentage van niveau I (27\%) bijna twee keer zo hoog als dat van niveau 4 (I4\%). Tegelijkertijd varieert het percentage dat het met de stelling (helemaal) niet eens is nauwelijks tussen de onderscheiden MBO-BOL niveaus. Dit komt overeen met de bevindingen voor deze onderwijsniveaus met betrekking tot de moeilijkheidsgraad van de opleiding. Onder de afgestudeerden van het $\mathrm{HBO}$ vindt 'slechts' $15 \%$ dat de docenten de studenten streng beoordeelden. $46 \%$ is het met deze stelling (helemaal) niet eens. Onder de afgestudeerden van de $\mathrm{HBO}$ sector onderwijs en de sector gedrag en maatschappij is zelfs een op de twee het (helemaal) niet eens met de stelling. Docenten in het WO worden in het algemeen als iets strenger ervaren dan de docenten in het HBO. 22\% van de WO afgestudeerden is het met de stelling eens, variërend van $17 \%$ (sector Gezondheidszorg) tot $26 \%$ (sectoren techniek en economie). Aan de andere kant is niet minder dan $40 \%$ van de afgestudeerden van mening dat de docenten niet streng beoordeelden. Vooral de afgestudeerden van de sector gezondheidszorg (48\%) zijn het met de stelling niet eens.

Een andere indicator voor de betrouwbaarheid van de selectie betreft de mate waarin de oud leerlingen hun gevolgde opleiding uitdagend qua niveau vonden. De stelling die hen is voorgelegd luidt: 'de opleiding was uitdagend qua niveau'. Van alle schoolverlaters is 'slechts' $32 \%$ het met deze stelling eens. Een vergelijkbaar percentage $(35 \%)$ is het met deze stelling helemaal niet eens. De WO afgestudeerden scoren met een gemiddelde van $55 \%$ beduidend hoger dan de andere onderwijsniveaus. Afgestudeerden uit de WO sector techniek en de sector natuurwetenschappen vinden zelfs in $66 \%$ van de gevallen dat hun studie uitdagend qua niveau was. HBO-ers vinden in $32 \%$ van de gevallen dat de opleiding uitdagend was. Een iets groter percentage van de $\mathrm{HBO}$-ers $(37 \%)$ is het met de stelling niet eens. Een uitschieter in negatieve zin zijn de lerarenopleidingen: slechts $23 \%$ van deze afgestudeerden vindt de opleiding uitdagend qua niveau, terwijl $47 \%$ dit (helemaal) niet vindt. De BBL-ers zijn iets vaker tevreden over het niveau dan hun collega studiegenoten met een BOL opleiding (36\% versus $30 \%$ is het eens met de stelling). BBL schoolverlaters uit de sector gedrag en maatschappij met een niveau 3 diploma op zak vinden zelfs vaak dat de opleiding uitdagend was. Van hen vindt $51 \%$ dat de opleiding uitdagend was terwijl 'slechts' $14 \%$ dit niet vindt. Ook de BOL niveau I schoolverlaters zijn redelijk tevreden. De overige BOL niveaus zijn vergelijkbaar met het landelijke cijfer. Ook de verschillen tussen de sectoren onderling zijn relatief klein. Qua niveau zijn de VMBO opleidingen het minst uitdagend (gemiddeld vindt $24 \%$ de opleiding uitdagend terwijl $40 \%$ dit niet vindt). Van de VMBO-tl uitstroom vindt zelfs maar één op de vijf gediplomeerden de opleiding goed wat deze indicator betreft. 
Figuur 3.7

Oordeel gediplomeerde schoolverlaters: Examens/opdrachten waren zeer pittig

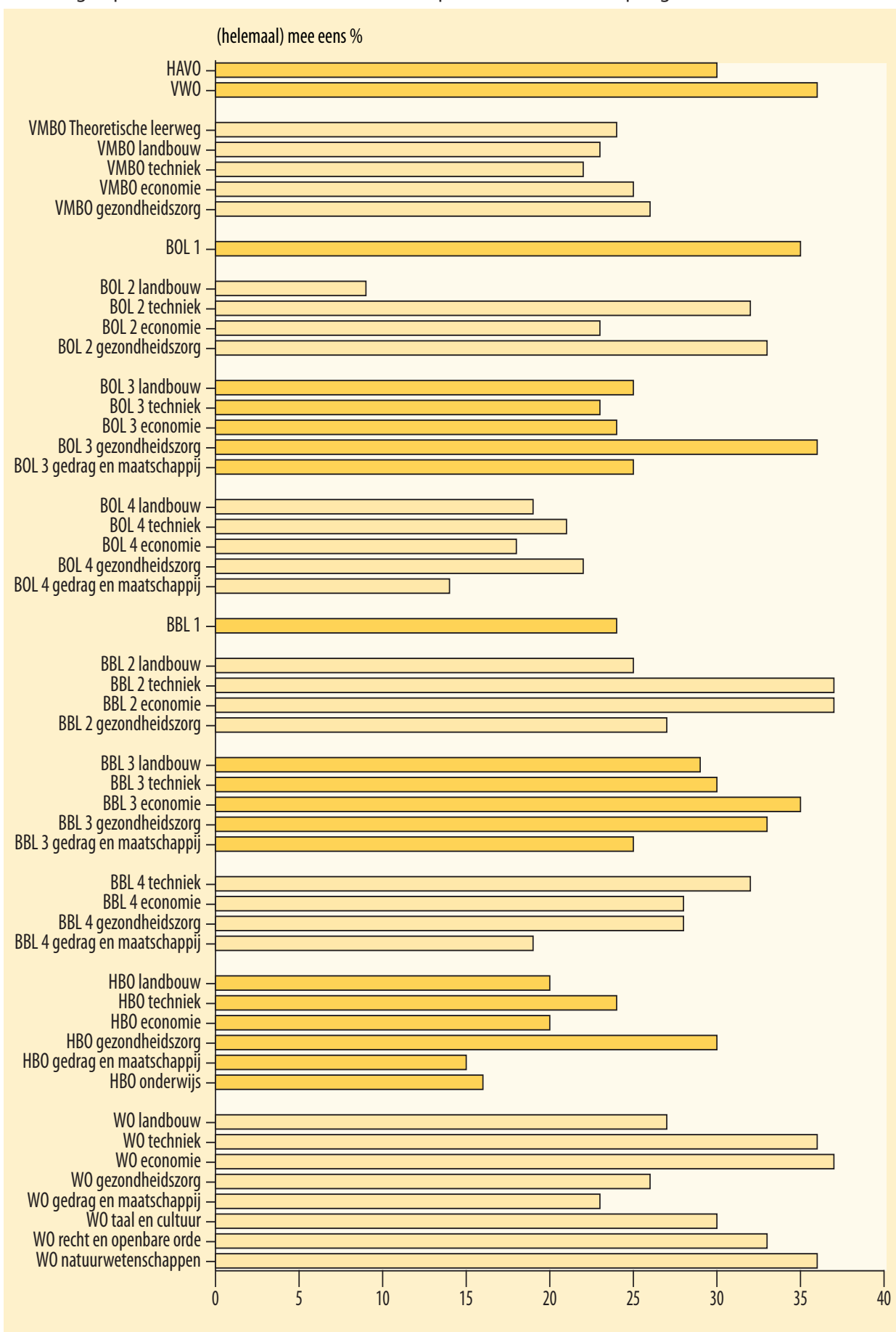

Zie ook Tabel A4.4 in de statistische bijlage. 
Vervolgens is aan de schoolverlaters de stelling 'de tentamens/opdrachten waren over het algemeen zeer pittig' voorgelegd. In figuur 3.7 zijn de resultaten met betrekking tot deze stelling per onderwijssoort weergegeven. ${ }^{\text {II }}$ Van alle schoolverlaters is $27 \%$ het met deze stelling (helemaal) eens en $36 \%$ (helemaal) oneens. Van de HAVO en VWO geslaagden vindt $32 \%$ de examens pittig (het jaar daarvoor was dit nog maar 27\%). Tegelijkertijd vindt $29 \%$ dat de examens (helemaal) niet pittig waren. De uitstroom van de BBL had gemiddeld meer moeite met de examens dan de uitstroom van de BOL. Behalve voor de niveau I opleidingen geven de BBL schoolverlaters iets vaker aan de examens pittig te hebben gevonden dan hun studiegenoten van de vergelijkbare BOL niveaus. Opvallend is verder de zeer lage score van de BOL niveau 2 gediplomeerden uit de sector landbouw. Hier geeft slechts één van de tien respondenten aan het met de stelling (helemaal) eens te zijn. De BOL niveau 3 schoolverlaters met een opleiding in de sector gezondheidszorg scoren daarentegen relatief hoog op dit onderdeel (36\% is het eens). Evenals verleden meetjaar lijkt het er op dat binnen de BOL als geheel de examens van de opleidingen op het hoogste niveau het minst pittig werden gevonden. $Z_{o}$ is I $8 \%$ van de schoolverlaters van het MBO-BOL niveau 4 het eens met de stelling, terwijl bijna een op de twee $(46 \%)$ het niet eens is met de stelling. Binnen het HBO lijkt het er op dat de examens in het algemeen niet als pittig ervaren worden. Slechts $20 \%$ is het namelijk eens met de stelling, terwijl $4 \mathrm{I} \%$ het niet eens is met de stelling. De examens in de sector onderwijs en de sector gedrag en maatschappij worden door zelfs nog een kleiner percentage als pittig ervaren. Zo vind $15 \%$ van de afgestudeerden van de $\mathrm{HBO}$ sector gedrag en maatschappij dat de examens pittig waren. $47 \%$ van de afgestudeerden uit deze sector is het hier (helemaal) niet mee eens. Voor de sector onderwijs zijn de cijfers respectievelijk I6\% en 50\%.

Binnen het WO vindt gemiddeld $30 \%$ dat de tentamens pittig waren, en $32 \%$ is het hier (helemaal) niet mee eens. Met name in de sectoren economie, techniek en natuurwetenschappen worden de examens lastig gevonden.

De laatste indicator voor de betrouwbaarheid van de selectie gaat over de vraag in hoeverre men vindt dat er in de opleiding voldoende getoetst is op inzicht (zie figuur 3.8). In totaal zijn vier van de tien afgestudeerden het (helemaal) eens met de stelling dat er tijdens de opleiding voldoende is getoetst op inzicht. Aan de andere kant is één op de vier schoolverlaters het hier niet mee eens (zie tabel A4.5). Afgestudeerden van het WO zijn het het vaakst met de stelling eens $(48 \%)$, maar ook onder deze groep schoolverlaters is nog bijna één op de vier het hiermee (helemaal) niet eens. In de sector WO-natuurwetenschappen is zelfs $63 \%$ het met de stelling eens en 'slechts' I $4 \%$ oneens. De HBO afgestudeerden zijn het het minst vaak met deze stelling eens. Zo is 'slechts' een op de drie HBO-afgestudeerden van mening dat er tijdens de opleiding voldoende op inzicht is getoetst. Dit is niet alleen minder vaak dan de WO afgestudeerden maar ook minder vaak dan de $\mathrm{VMBO}$ schoolverlaters. In deze laatste groep is $40 \%$ het met de stelling eens en $22 \%$ niet. De schoolverlaters van de theoretische leerweg scoren binnen het $\mathrm{VMBO}$ het laagst op dit onderdeel, ook lager dan hun jaargenoten met een HAVO of VWO diploma. Binnen de BOL zijn het de schoolverlaters van niveau 4 die met $31 \%$ het minst vaak vinden dat er voldoende op inzicht getoetst werd. Over alle BOL niveaus is het met name in de opleidingssector landbouw waar wat minder op inzicht getoetst lijkt te worden. Opvallend is verder dat zowel binnen de BOL als de BBL de niveau I opleidingen de hoogste score halen op dit onderdeel, en de niveau 4 opleidingen de laagste. Gemiddeld

II. De cijfers voor de schoolverlaters die het niet eens zijn met deze stelling, vindt $\mathrm{u}$ in tabel $\mathrm{A}_{4.4}$ van de statistische bijlage. 
genomen zijn de BBL-ers vaker van mening dat er voldoende op inzicht getoetst werd dan hun studiegenoten met een BOL achtergrond.

\section{Figuur 3.8}

Oordeel gediplomeerde schoolverlaters: Voldoende getoetst op inzicht

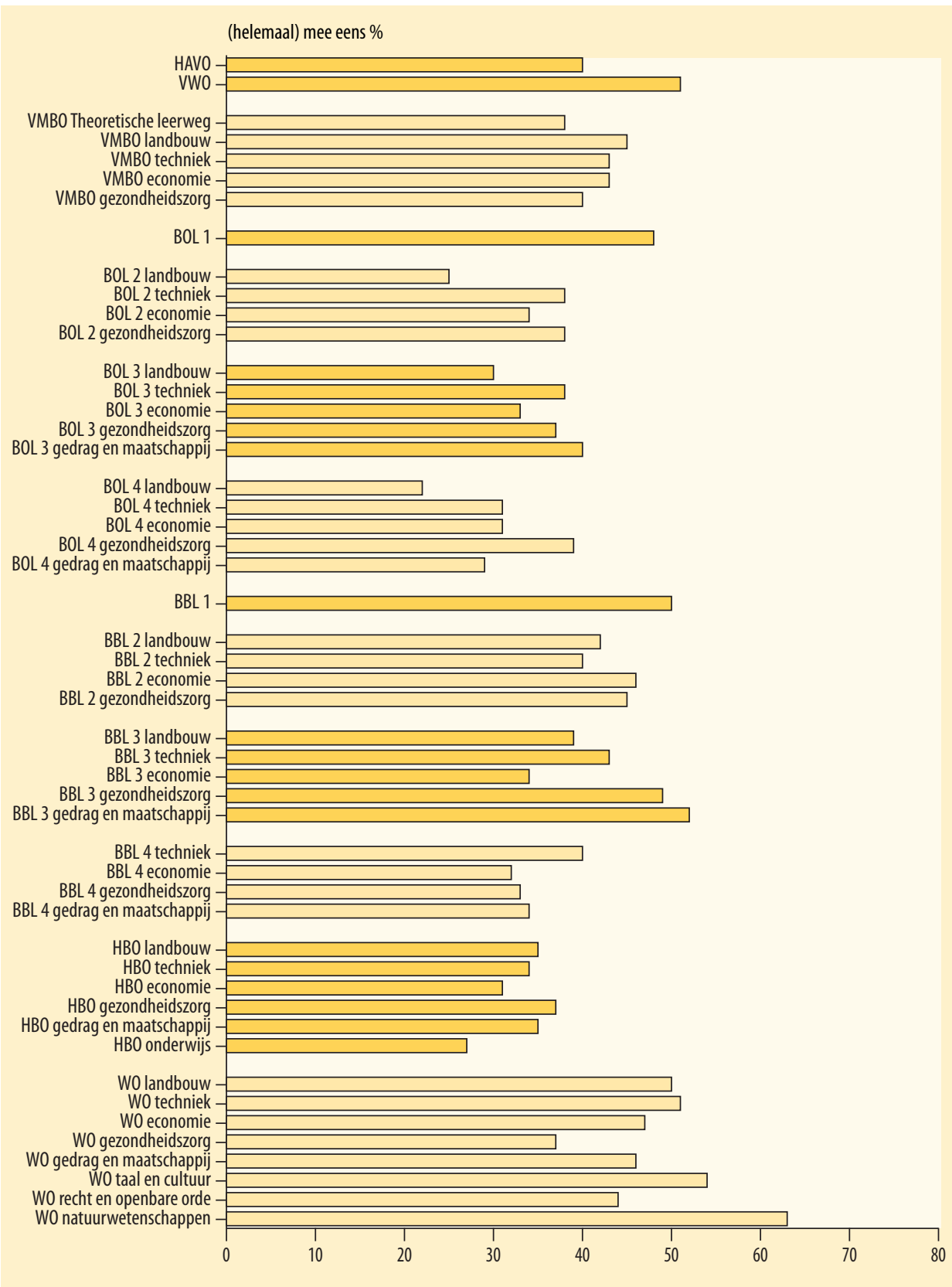

Zie ook Tabel A4.5 in de statistische bijlage. 
Samenvattend kan vastgesteld worden dat schoolverlaters wat betreft de 'selectie' nogal kritisch naar de afgeronde opleiding kijken. Volgens de schoolverlaters zijn de opleidingen redelijk makkelijk, worden de scholieren/studenten door hun docenten niet streng beoordeeld, zijn de opleidingen (met uitzondering van de universitaire opleidingen) niet echt uitdagend en zijn de examens niet echt pittig. 


\section{Kwalificerende vervolgtrajecten}

$\mathrm{Na}$ het behalen van het diploma staan schoolverlaters voor een belangrijke keuze. Men kan toetreden tot de arbeidsmarkt of kiezen voor een vervolgtraject in het onderwijs. Om de allocatiefunctie in kaart te brengen worden deze twee groepen apart behandeld. In dit hoofdstuk gaat het om de uitstroom die kiest voor een vervolgstudie. Onder verder lerende schoolverlaters verstaan we hierbij zowel degenen die de studie vervolgen in een volledige dagopleiding als degenen die werken en leren combineren ( $M B O-B B L$ of $H B O-D u a a l)$. Aanvullende scholing in de vorm van cursussen, bedrijfsopleidingen en dergelijke blijft hier buiten beschouwing.

Vanwege de geringe doorstroom vanuit de BBL naar het vervolgonderwijs zullen de cijfers van de BBL in dit hoofdstuk in de figuur niet nader naar sector gespecificeerd worden. In het volgende hoofdstuk gaat het om de uitstroom die kiest voor de arbeidsmarkt en zullen de individuele BBL sectoren wel weer getoond worden.

Allocatie

De grootte van de uitstroom naar het vervolgonderwijs hangt uiteraard voor een groot deel samen met het niveau van het behaalde diploma. De gediplomeerde uitstroom uit het VO kiest voor het merendeel voor een vervolgstudie. De uitstroom uit het $\mathrm{MBO}$ kiest voor ongeveer de helft een vervolgstudie en de afgestudeerden uit het hoger onderwijs gaan vrijwel allemaal op zoek naar een baan.

Om zicht te krijgen op de doorstroom tussen de diverse onderwijssoorten wordt allereerst bekeken in welk soort onderwijs men verder gaat leren (figuur 4.9 en 4.IO). Daarna bespreken we enkele aspecten van de aansluiting tussen de gevolgde opleiding en de vervolgopleiding. Hierbij kijken we naar de doorstroom naar verwante beroepsopleidingen (figuur 4.II) en de tevredenheid van verder lerende schoolverlaters over de aansluiting tussen de afgesloten opleiding en de vervolgopleiding (4.I2).

Een overzicht van de kwalificerende vervolgtrajecten van de respondenten staat in figuur 4.9. De figuur vermeldt het procentuele aandeel per onderwijssoort dat sinds het afstuderen naar een bepaald kwalificerend vervolgtraject is gegaan evenals het percentage dat niet voor een kwalificerend vervolgtraject heeft gekozen. Vanwege de overzichtelijkheid zijn in figuur 4.9 alleen vervolgtrajecten met een aandeel van ten minste $5 \%$ opgenomen. Daarnaast zijn de BOL en BBL niveaus samengevoegd. 
Het merendeel van de respondenten van het VO blijft voor het onderwijs behouden en stroomt door naar een vervolgstudie. Van de HAVO-ers gaat $80 \%$ naar het $\mathrm{HBO}$, I2\% gaat niet verder studeren en de overige $8 \%$ gaat een andere dan een $\mathrm{HBO}$ studie doen. Ook I $_{2} \%$ van de VWO-ers kiest voor een ander vervolgtraject dan het onderwijs. 69\% gaat een universitaire studie volgen en $19 \%$ kiest voor het hoger beroepsonderwijs. Ondanks dat een VMBO diploma geen startkwalificatie is gaat II\% niet verder leren. Degenen die dat wel doen gaan voor het merendeel (68\%) naar de BOL variant van het $\mathrm{MBO}$, slechts II\% kiest voor het duale $\mathrm{MBO}$ traject.

Van de BOL-ers stopt 58\% met studeren, $29 \%$ gaat verder met een HBO studie en $8 \%$ blijft binnen dezelfde onderwijssoort. De arbeidsmarkt is duidelijke een belangrijke factor voor de BBL-ers, slechts $15 \%$ van de respondenten gaat verder met een andere opleiding en kiest daarbij vooral weer voor een duaal traject in het $\mathrm{MBO}$. $2 \mathrm{I} \%$ van de afgestudeerden van het $\mathrm{HBO}$ gaat verder met een WO studie. Een klein deel blijft binnen het $\mathrm{HBO}$ onderwijs maar het overgrote deel stopt met volgen van regulier onderwijs (65\%). Een vergelijkbaar deel van de WO-ers verlaat het onderwijs alhoewel toch nog $32 \%$ kiest voor een vervolgstudie.

\section{Figuur 4.9}

Kwalificerende vervolgtrajecten na het verlaten van de opleiding (\% respondenten)

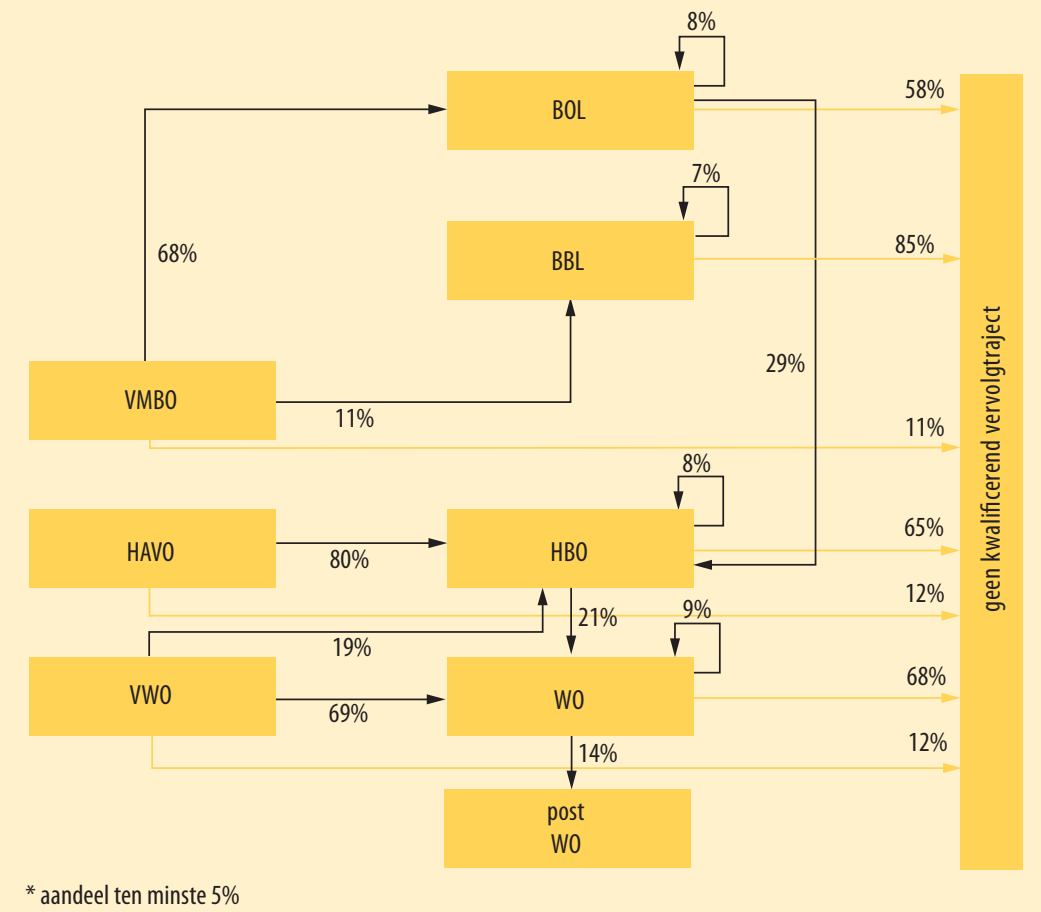

Zie ook Tabel A5.2 in de statistische bijlage. 
In het geval van de gediplomeerde schoolverlaters van het VMBO speelt niet alleen de vraag of zij voor een kwalificerend vervolgtraject hebben gekozen een belangrijke rol, maar, indien dit vervolgtraject in het $\mathrm{MBO}$ plaatsvindt, voor welk niveau zij gekozen hebben. Figuur 4.Io laat voor de $\mathrm{VMBO}$-schoolverlaters die voor het $\mathrm{MBO}$ hebben gekozen het percentage zien dat in een bepaald $\mathrm{MBO}$-niveau instroomt. In tegenstelling tot de andere figuren in dit hoofdstuk onderscheiden we daarbij niet de opleidingssectoren in het VMBO maar de leerwegen.

De gediplomeerden van de basisberoepsgerichte leerweg gaan het minst vaak verder met een vervolgstudie, $26 \%$ verlaat het onderwijs. Degenen die wel verder studeren doen dit voor het merendeel $(37 \%)$ in een BOL niveau 2 opleiding, I6\% kiest voor hetzelfde niveau maar doet dit in de duale variant. In absolute aantallen is de gemengde leerweg de kleinste leerweg, van dit traject gaat echter het overgrote deel verder met een andere opleiding. Zo'n $64 \%$ van de totale uitstroom gaat verder met een BOL niveau 4 opleiding, I $8 \%$ met een BOL niveau 3 opleiding. Zowel van de kaderberoepsgerichte leerweg als de theoretische leerweg gaan bijna negen van de tien gediplomeerden verder met een andere opleiding. Vanuit de kaderberoepsgerichte leerweg stroomt men met name door naar BOL niveau 3 (24\%) en BOL niveau 4 $(38 \%)$. Hier vindt ook het grootste deel van de theoretische leerweg zijn vervolgstudie. Meer dan de helft van de gediplomeerde uitstroom $(56 \%)$ gaat naar een BOL niveau 4 opleiding, zo'n II\% naar BOL niveau 3.

\section{Figuur 4.10}

Kwalificerende MBO-vervolgtrajecten na het verlaten van de VMBO-opleiding (\% respondenten)

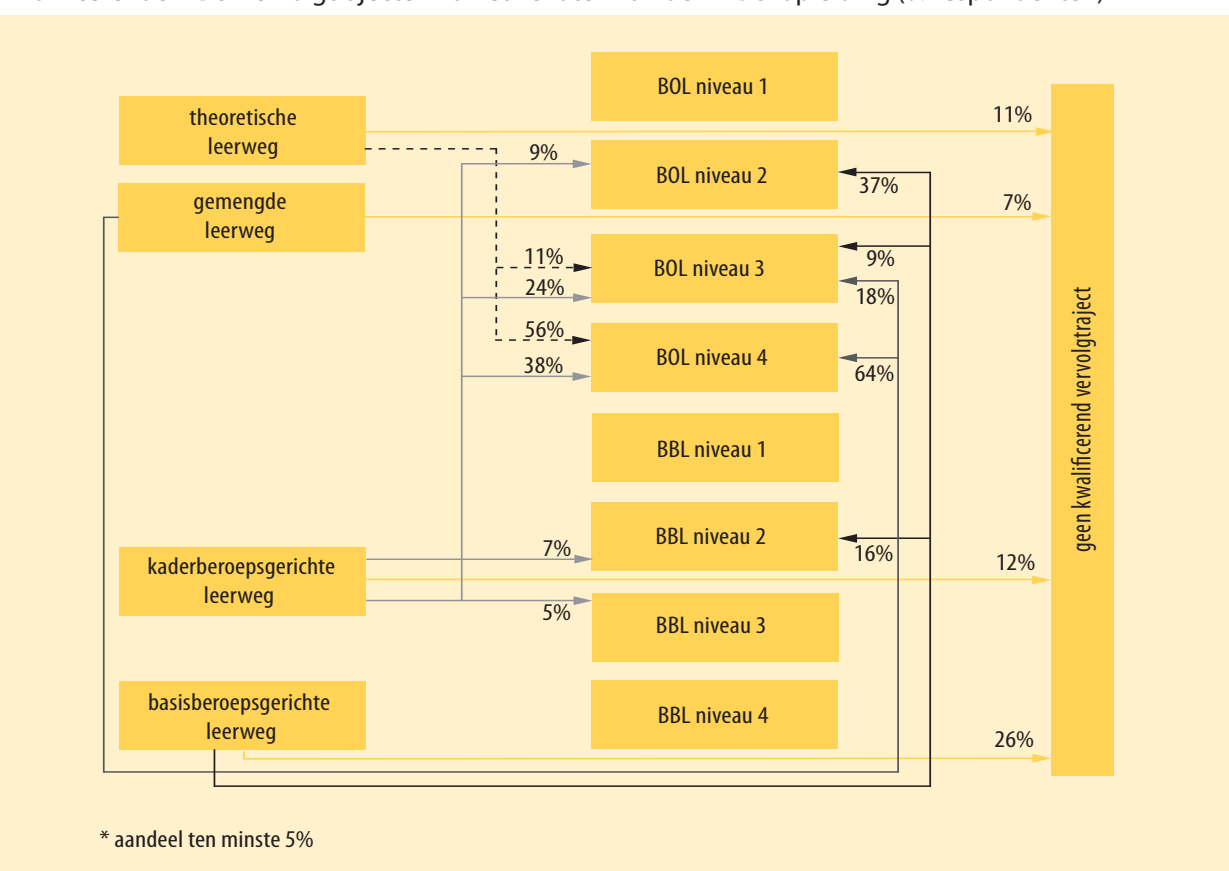

Zie ook Tabel A5.2 in de statistische bijlage. 
Het is voor onderwijssectoren van belang om te weten wat de doorstroom naar vervolgstudies is en hoe deze is opgebouwd. Daarnaast is het echter ook belangrijk om inzicht te hebben in hoe groot de doorstroom binnen de eigen sector is. Met andere woorden, welk deel van de verder lerende schoolverlaters kiest voor een vervolgstudie binnen dezelfde opleidingsrichting? Door de opleidingsrichting te vergelijken met de richting van de gekozen vervolgopleiding kan worden bepaald welk percentage van de verder lerende schoolverlaters voor dezelfde richting gekozen heeft. De resultaten hiervan staan in figuur 4.II. Voor de algemene richtingen binnen het voortgezet onderwijs, het HAVO, het VWO, en de VMBO theoretische leerweg zijn deze cijfers niet relevant. Voor het WO geldt dat het vervolgonderwijs dikwijls een niet regulier karakter heeft waardoor de onderwijsrichting vaak niet eenduidig vast te stellen is.

\section{Figuur 4.11}

Doorstroom naar verwante opleidingen per opleidingssector in het beroepsonderwijs

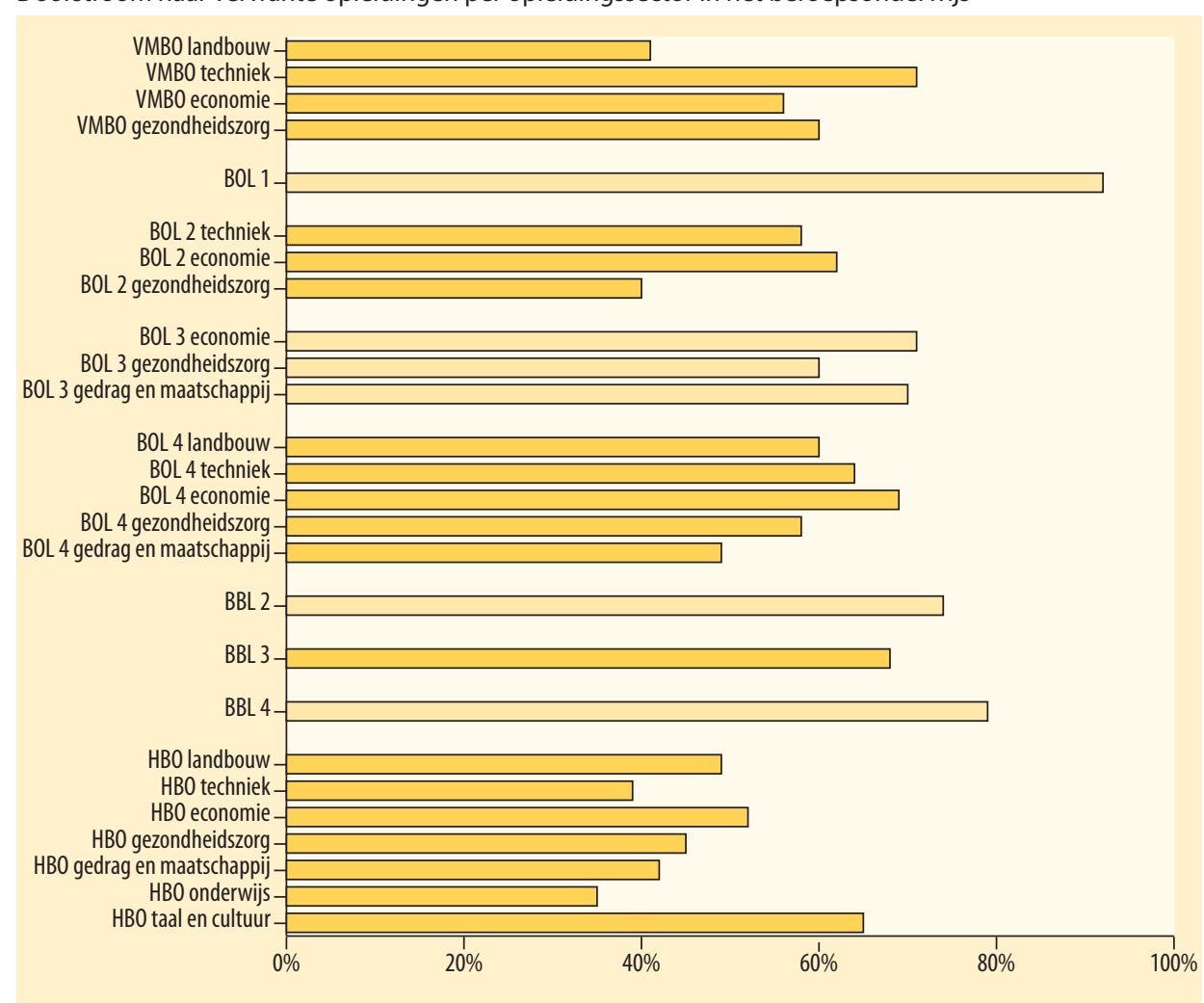

In totaal gaan bijna zes van de tien verder lerende schoolverlaters een studie volgen die wat betreft richting in het verlengde ligt van hun afgesloten opleiding. Dit gebeurt het vaakst onder de gediplomeerde uitstroom van de BBL, 73\% kiest voor een verwante vervolgstudie. In vergelijking met de andere onderwijssoorten kiezen de $\mathrm{HBO}$ afgestudeerden het vaakst voor een vervolgstudie in een andere richting, alhoewel ook hier nog steeds $46 \%$ een vervolgopleiding in dezelfde richting is gaan volgen. Van de verder lerende schoolverlaters met een BOL niveau I diploma gaat bijna iedereen (92\%) naar een vervolgstudie met een verwante 
richting. Van alle onderwijsniveaus is dit het hoogste percentage. Binnen de BOL zijn het in het algemeen met name de uitstromers met een economische opleiding die een vervolgopleiding in dezelfde richting volgen. De gediplomeerde BBL-ers gaan iets vaker dan hun studiegenoten van de BOL naar een verwante vervolgopleiding. Van de niveau 4 BBL gediplomeerden geldt dit voor bijna acht van de tien personen.

\section{Figuur 4.12}

Percentage van de verder lerende schoolverlaters dat de aansluiting tussen de gevolgde opleiding en de vervolgopleiding voldoende of goed vindt

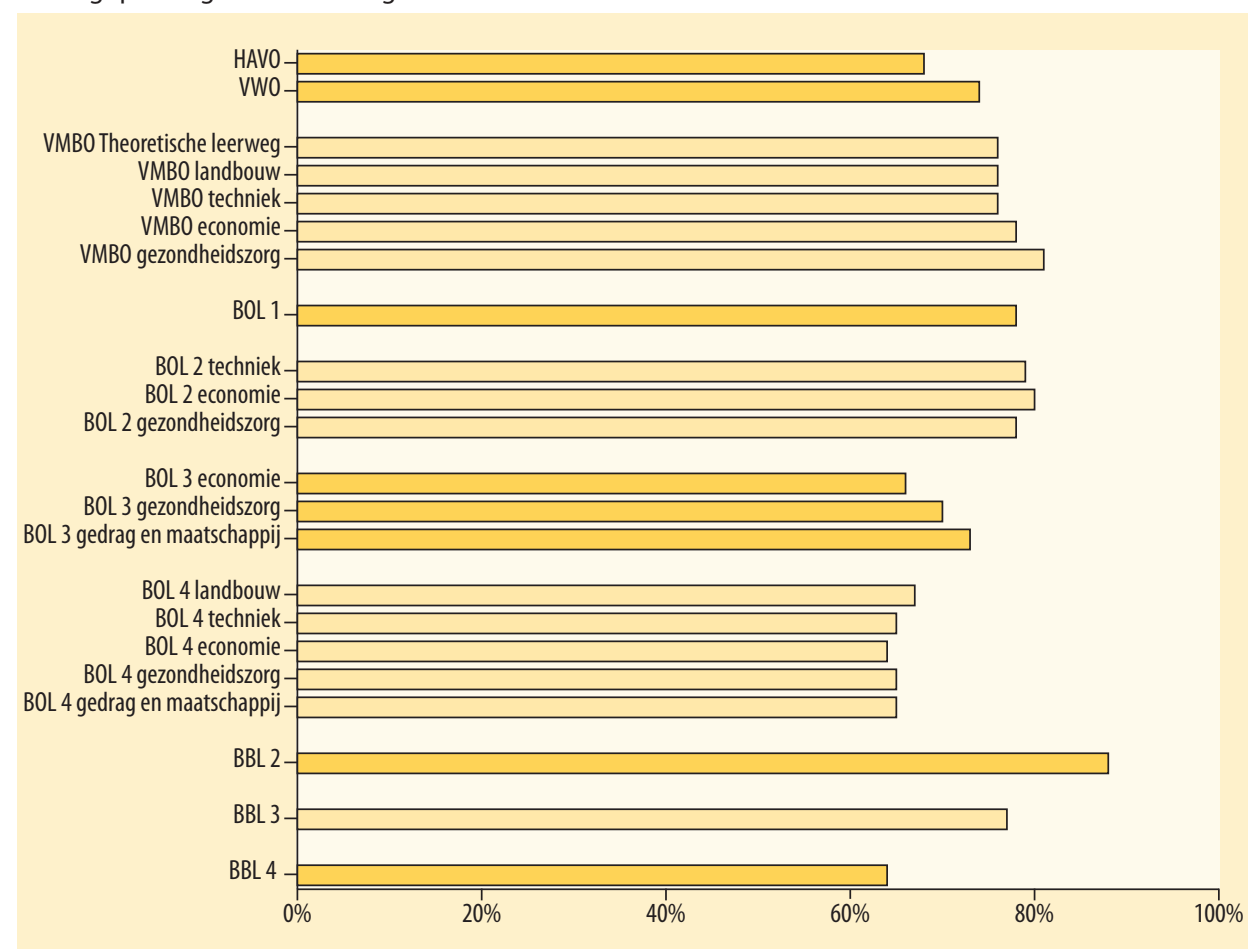

Zie ook Tabel A5.5 in de statistische bijlage.

Doorstromen naar een vervolgopleiding in dezelfde onderwijssector betekent niet automatisch dat de aansluiting tussen de gevolgde en de vervolgopleiding goed is. Zo hoeft de aansluiting tussen twee opleidingen uit verschillende onderwijssectoren ook niet per definitie slecht te zijn. De schoolverlaters is daarom gevraagd, ongeacht of ze een vervolgstudie in verwante richting zijn gaan doen, wat ze vinden van de aansluiting tussen hun gevolgde en vervolgstudie. In figuur 4.I2 staan de percentages van de verder lerende schoolverlaters die de aansluiting tussen de afgeronde en de vervolgopleiding (alleen volledige dagopleiding) goed of voldoende vinden. Vanwege de relatief geringe doorstroom vanuit het hoger onderwijs naar het reguliere vervolgonderwijs is de desbetreffende vraag niet aan $\mathrm{HBO}$ en WO afgestudeerden voorgelegd en zijn er voor het hoger onderwijs dan ook geen gegevens met betrekking tot dit onderdeel beschikbaar.

Bijna driekwart (74\%) van alle schoolverlaters die een vervolgopleiding zijn gaan volgen, vindt de aansluiting tussen de gevolgde opleiding en deze vervolgstudie redelijk tot goed. Onder 
de schoolverlaters die doorstromen binnen dezelfde opleidingssector is dit iets hoger, terwijl het bij de schoolverlaters die voor een andere opleidingssector kiezen anzienlijk lager is. Met $78 \%$ scoort de $\mathrm{VMBO}$ als onderwijssoort iets boven het landelijke gemiddelde, vooral de sector VMBO gezondheidszorg $(8 \mathrm{I} \%)$ doet het goed. Opvallend is verder dat er slechts zeer geringe verschillen zijn tussen de verschillende VMBO sectoren onderling. Zowel voor de BOL (69\%) als de $\mathrm{BBL}(8 \mathrm{I} \%)$ geldt dat met name de verder lerende uitstroom van de niveau 2 opleidingen tevreden is met de aansluiting met het vervolgonderwijs. De gediplomeerden van de niveau 4 opleidingen zijn binnen beide onderwijssoorten, BOL en BBL, het minst vaak tevreden.

\section{Rendement}

Een van de functies van het onderwijs is het voorbereiden van leerlingen op een eventueel vervolgtraject in het onderwijs. Om het rendement hiervan te meten, kijken we naar het percentage dat de vervolgopleiding op het moment van de enquête (ongeveer anderhalf jaar na het behalen van het diploma) weer heeft verlaten of van studie is gewisseld. Daarnaast bespreken we het percentage dat in de vervolgopleiding is bevorderd naar het tweede leerjaar/ studiejaar. Een relatief grote uitval kan duiden op een gebrekkige aansluiting. Deze gebrekkige aansluiting kan meerdere oorzaken hebben: het curriculum van een of beide opleidingen is niet passend, een gebrekkige studiekeuzevoorlichting, de aantrekkingskracht van de arbeidsmarkt. Het ongediplomeerd verlaten van de vervolgstudie wil niet altijd zeggen dat men het onderwijstraject definitief verlaten heeft. In figuur 4.13 is daarom, naast het aandeel verder lerende schoolverlaters die de vervolgopleiding voortijdig verlaten hebben, ook aangegeven welk deel van deze voortijdige schoolverlaters van studie gewisseld is.

Gemiddeld heeft II\% van de personen die doorstromen naar een vervolgopleiding, deze na anderhalf jaar weer ongediplomeerd verlaten. Zo'n 7\%-punt bestaat uit zogenaamde studiewisselaars, schoolverlaters die niet tevreden waren met hun eerste vervolgstudie en van studie gewisseld zijn. 4\%-punt bestaat uit echte uitval. De verschillen tussen de verscheidene onderwijssoorten zijn groot. Het algemene beeld is dat zowel het percentage voortijdig schoolverlaters als het percentage studiewisselaars daalt naarmate het onderwijsniveau stijgt. Ter vergelijking, onder de verder lerende HAVO en VWO schoolverlaters is de voortijdige uitval I $4 \%$ waarvan zo'n II\%-punt wisselaars zijn. Onder de verder lerende WO afgestudeerden is de uitval bijna $5 \%$ waarvan slechts een verwaarloosbaar deel wisselaar is. De gediplomeerden van het $\mathrm{VMBO}$ en de MBO niveau I opleidingen beschikken niet over een startkwalificatie en kunnen zich dus beter richten op een succesvol vervolg in het onderwijs. Van de verder lerende VMBO-ers houdt bijna II\% in de eerste I8 maanden van de vervolgstudie er mee op. Gelukkig zijn 7\%-punt hiervan personen die daarna weer met een andere studie beginnen. De cijfers voor de verder lerende BOL niveau I schoolverlaters zijn iets minder positief: het lijkt er op dat II\%-punt van de I4,4\% uitvallers bestaat uit personen die (vooralsnog) niet aan een andere studie begonnen zijn. BBL-ers houden iets minder vaak voortijdig met de vervolgstudie op dan de schoolverlaters met een BOL achtergrond. Opvallend is verder dat binnen de meeste BOL en BBL niveaus de schoolverlaters uit de sector gezondheidszorg het minst vaak ophouden met hun vervolgstudie. In het HBO zijn het met name (Iо,3\%) de technici die stoppen met de vervolgopleiding, slechts I\%-punt van hen blijkt studiewisselaar te zijn. Uit de figuur blijkt verder dat slechts weinige afgestudeerde WO-ers direct met een nieuwe vervolgstudie beginnen nadat ze de initiële vervolgstudie hebben afgebroken. Interessant is verder dat er geen duidelijke verschillen zijn tussen schoolverlaters die doorstromen binnen 
dezelfde opleidingssector en schoolverlaters die voor een andere opleidingssector kiezen. Met andere woorden, de iets gebrekige aansluiting indien men voor een andere opleidingssector kiest, resulteert niet in een hogere kans op uitval.

Aan de verder lerende schoolverlaters die nog bezig zijn met hun vervolgopleiding is daarnaast gevraagd of zij bevorderd zijn naar het tweede leerjaar/studiejaar (cijfers zijn niet beschikbaar voor het hoger onderwijs). Gemiddeld krijgt van deze groep slechts één op de tien eerstejaars geen toegang tot de volgende fase van de vervolgstudie. Het VMBO doet het iets beter dan het landelijk gemiddelde, de BOL en de BBL liggen er iets onder. Binnen het VMBO zijn de verschillen tussen de onderlinge sectoren klein. Binnen de BOL halen de verder lerende schoolverlaters van de niveaus I en 2 het minst vaak het tweede leerjaar van de vervolgopleiding, zo'n $74 \%$ stroomt door naar het tweede jaar. De niveau 3 opleidingen uit de BOL sector gezondheidszorg sluiten het slechts aan op de vervolgstudies wat betreft het aspect doorstroom naar tweede leerjaar: slechts zes van de tien van hen zijn tot het moment van de enquête bevorderd. Binnen de BOL hebben de niveau 4 techniek opleidingen met $89 \%$ het hoogste percentage. De BBL niveau 3 en 4 opleidingen doen het gemiddeld genomen vergelijkbaar met de BOL niveaus, schoolverlaters van BBL niveau 2 hebben gemiddeld iets meer succes in hun eerste jaar van de vervolgstudie dan hun collega's met een BOL variant vooropleiding.

Nadat figuur 4.I3 heeft laten zien welk percentage van de verder lerende schoolverlaters bevorderd, of alweer gestopt, of van studie gewisseld is, geeft figuur 4.I4 een indicatie welke vervolgstudies de grootste slaagkans en uitval kennen. In tegenstelling tot alle andere figuren zijn de cijfers in figuur 4.I4 niet gepresenteerd naar de sector van de afgesloten opleiding maar naar die van de vervolgopleiding. Voor de individuele onderwijssectoren is het van belang een zo laag mogelijke uitval te hebben. Op macroniveau is het echter van even groot belang hoe groot het percentage echte uitvallers is. Als er in een bepaalde sector een hoge initiële uitval is brengt dit kosten met zich mee. Deze hoge uitval kan bijvoorbeeld veroorzaakt worden door gebrekkige studievoorlichting of een minder goede aansluiting tussen de gevolgde en de vervolgopleiding. Voor het gehele onderwijsveld, en voor de individuele schoolverlaters zelf, gaat het echter met name om de vraag welk deel van deze uitvallers echt uit het reguliere onderwijs stapt en welk deel van studie wisselt. Omdat de uitstroom vanuit het basisonderwijs niet gemeten wordt zijn de cijfers voor de vervolgopleidingen in het voortgezet onderwijs en de niveau I opleidingen in het MBO niet representatief, deze zijn dan ook niet in figuur 4.I4 opgenomen.

Binnen de BOL ligt de uitval voor alle niveaus rond de $11 \%$. Dit is vergelijkbaar met de meting in 2006. Op BOL niveau 2 bestaat deze $\mathrm{II} \%$ voor $6 \%$-punt uit studiewisselaars, op BOL niveau 3 voor $7 \%$-punt en op BOL niveau 4 voor $8 \%$-punt. Vooral voor de echte uitval op BOL niveau 2 van ongeveer $5 \%$ is dit een probleem want deze schoolverlaters beschikken niet over een startkwalificatie. Op BOL niveau 2 is de laagste echte uitval in de sector landbouw, leerlingen van de sector techniek stoppen op dit niveau het vaakst met het volgen van regulier onderwijs. Ook op BOL niveau 3 zijn het de schoolverlaters die een technische studie gekozen hebben die het vaakst uitvallen zonder een ander studie te gaan volgen. In de sectoren gezondheidszorg en gedrag en maatschappij is de uitval het laagst. Evenals op niveau 2 zijn de verschillen tussen de sectoren onderling binnen niveau 4 niet erg groot. Ook hier kennen de sectoren gezondheidszorg en gedrag en maatschappij de laagste uitvalpercentages voor zover het schoolverlaters betreft die niet van studie wisselen. 


\section{Figuur 4.13}

Percentage van de verder lerende schoolverlaters dat bevorderd is naar het tweede leerjaar/studiejaar, percentage dat de vervolgopleiding voortijdig heeft verlaten (uitvallers) en het percentage dat een andere opleiding is gaan volgen (studiewisselaars)

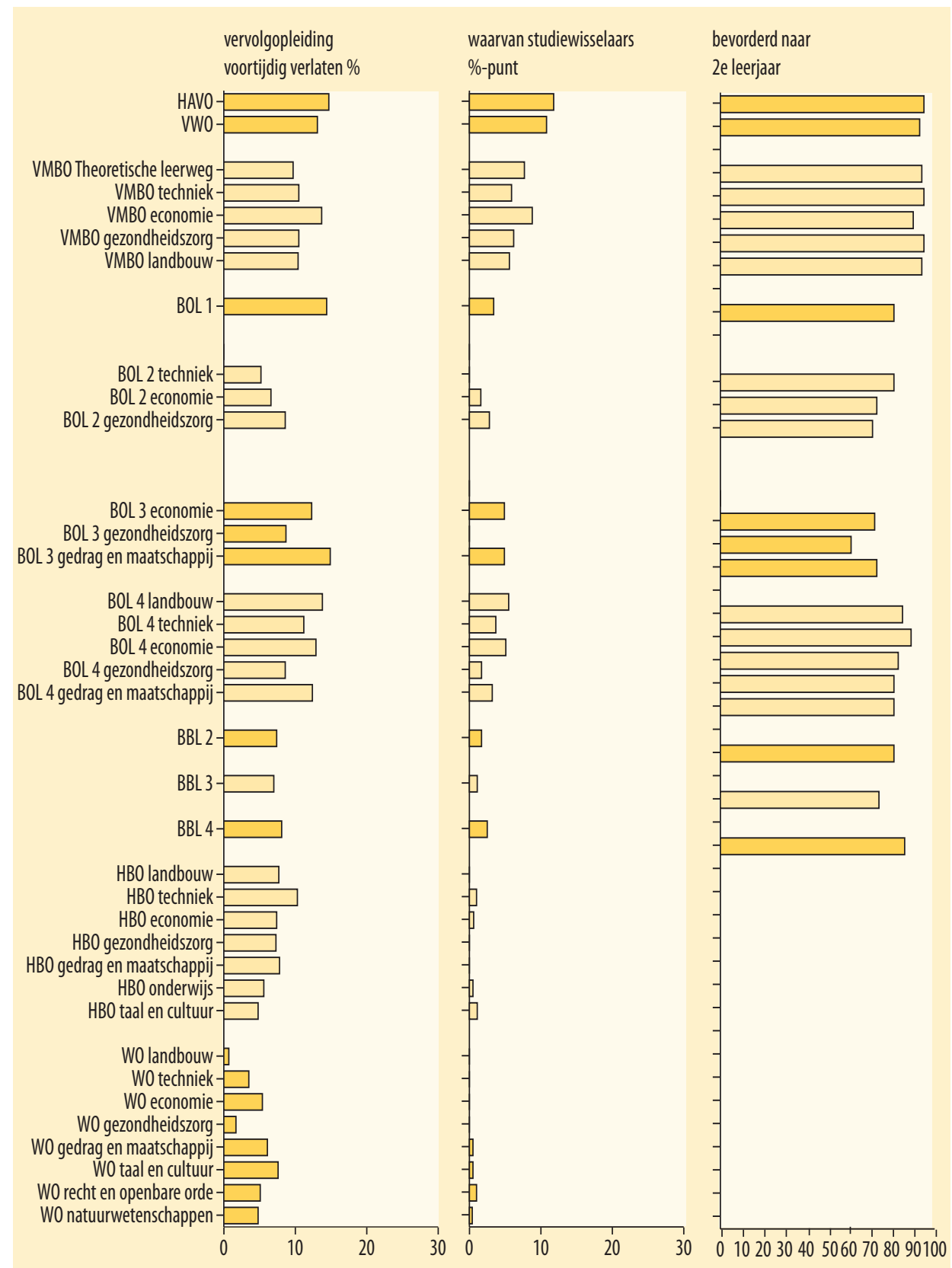

Zie ook Tabel A6.1 in de statistische bijlage. 


\section{Figuur 4.14}

Percentage van de verder lerende schoolverlaters dat bevorderd is naar het tweede leerjaar/studiejaar, percentage dat de vervolgopleiding voortijdig heeft verlaten (uitvallers) en het percentage dat een andere opleiding is gaan volgen (studiewisselaars) naar sector vervolgopleiding

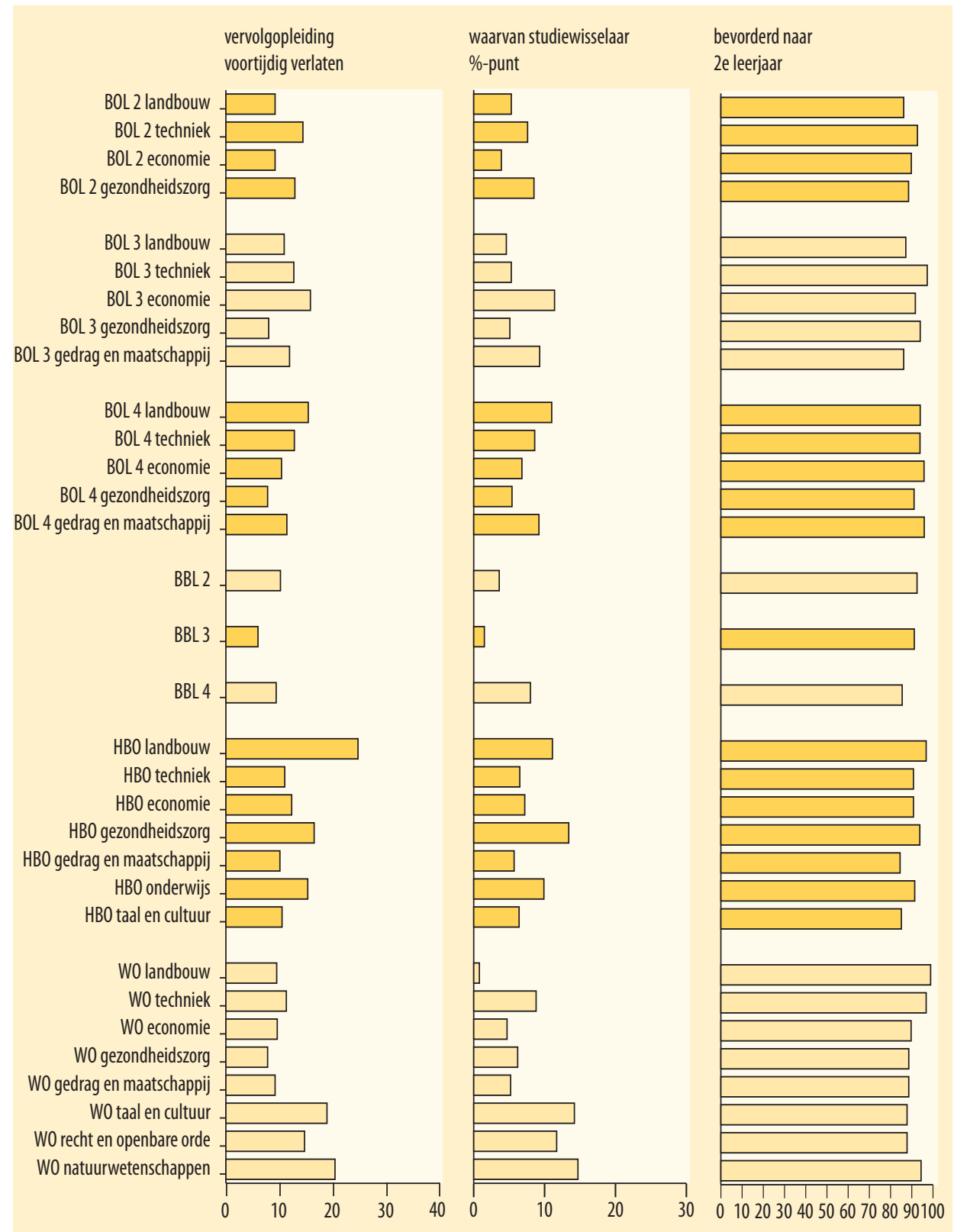

Met een totale uitval van $6 \%$ doen de opleidingen van de BBL niveau 3 het iets beter dan de opleidingen van de BBL niveaus 2 en 4 . Het percentage werkelijke uitval is op niveau 4 echter het laagst (I\%) doordat op de andere niveaus het percentage studiewisselaars relatief laag is. 
Ten opzichte van de andere onderwijsniveaus ligt de uitval binnen het $\mathrm{HBO}$ relatief hoog. De $\mathrm{HBO}$ sector landbouw kent met bijna 25\% een bijzonder hoge uitval. Zo'n II\%-punt hiervan zijn studiewisselaars. De sector gezondheidszorg kent weliswaar ook een hoog percentage ( $16 \%)$ uitvallers, maar vrijwel al deze leerlingen kiezen voor een andere studie. Het gemiddeld uitvalpercentage in het WO ligt op II\%. Hier zijn het met name de sectoren taal en cultuur, natuurwetenschappen en recht en openbare orde waarvan veel studenten gedurende de eerste I8 maanden van de studie er mee stoppen. De percentages studiewisselaars liggen in deze sectoren ook relatief hoog.

\section{Tevredenheid achteraf}

In figuur 4.15 is het percentage verder lerende schoolverlaters weergegeven dat de afgesloten opleiding, achteraf bezien, opnieuw zou volgen. Bij deze analyse wordt alleen gekeken naar schoolverlaters van het $\mathrm{MBO}$, en het hoger onderwijs. Deze schoolverlaters hebben gekozen voor een vervolgstudie maar hadden, met uitzondering van schoolverlaters van $\mathrm{BOL} / \mathrm{BBL}$ niveau I, met hun al behaalde kwalificatie, ook de arbeidsmarkt kunnen betreden.

\section{Figuur 4.15}

Percentage verder lerende schoolverlaters dat de afgesloten opleiding achteraf bezien opnieuw zou volgen

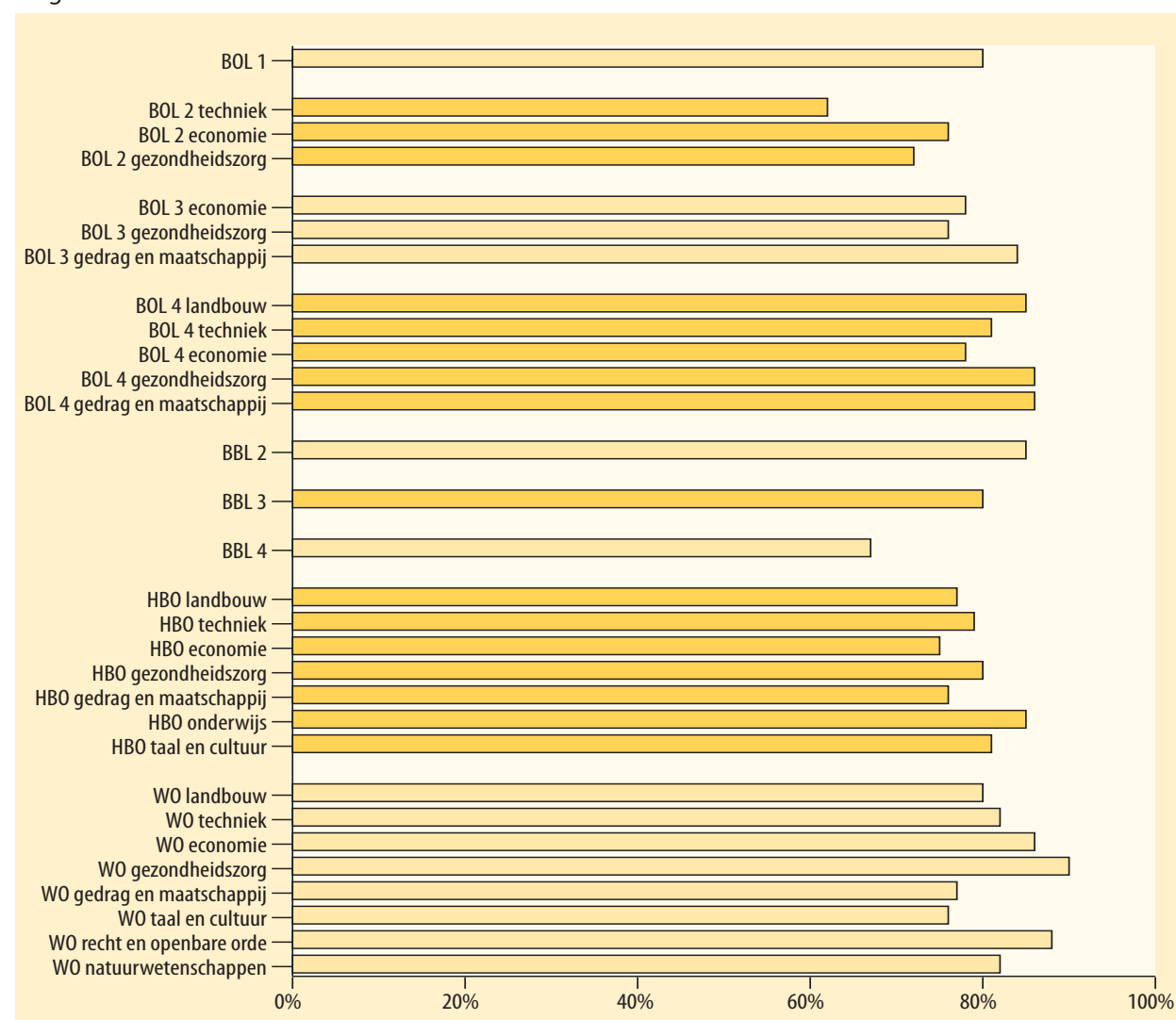

Zie ook Tabel A7.1 in de statistische bijlage. 
Er is weinig verschil tussen de afgestudeerden van het $\mathrm{MBO}$, het $\mathrm{HBO}$ en het WO wat betreft het aandeel verder lerende schoolverlaters dat de afgesloten opleiding opnieuw zou kiezen: ongeveer $80 \%$ van de verder lerende schoolverlaters zou dit doen. De resultaten zijn vergelijkbaar met die van verleden jaar. Binnen de BOL zouden de schoolverlaters van de niveau 2 opleidingen het minst vaak kiezen voor de afgesloten opleiding, drie van de tien van hen zouden een andere of geen opleiding zijn gaan volgen als ze opnieuw voor de keuze zouden staan. Met name de schoolverlaters uit de niveau 2 techniek opleidingen hadden liever anders gekozen (38\%). De verder lerende schoolverlaters van de niveau 3 en 4 opleidingen zijn duidelijk meer tevreden. In het MBO-BBL zijn het vooral de 'verder lerende' schoolverlaters van het niveau 4 die liever iets anders hadden gekozen. In het $\mathrm{HBO}$ kiezen de afgestudeerden van de economische opleidingen het vaakst $(25 \%)$ voor een andere opleiding als ze een tweede kans zouden hebben gekregen, de gediplomeerde leraren hebben het minst spijt van hun destijds gemaakte studiekeuze. In het WO scoren de sectoren gezondheidszorg (90\% zelfde studie) en recht en openbare orde ( $88 \%$ zelfde studie) het hoogst, verder lerende afgestudeerden van de sector taal en cultuur zouden het vaakst voor iets anders gekozen hebben. 


\section{Intrede op de arbeidsmarkt}

In het vorige hoofdstuk hebben de verder lerende schoolverlaters centraal gestaan. Het onderwijs wordt geacht leerlingen kennis en vaardigheden bij te brengen zodat ze met voldoende competenties de arbeidsmarkt kunnen betreden. Om inzicht te krijgen in het rendement van het onderwijs met betrekking tot dit aspect wordt in dit hoofdstuk gekeken naar dat deel van de gediplomeerde schoolverlaters dat na het verlaten van de opleiding zijn intrede doet op de arbeidsmarkt. Dit wordt gedaan voor de gediplomeerde schoolverlaters die op het moment van ondervraging (ongeveer anderhalf jaar na het behalen van het diploma) tot de beroepsbevolking worden gerekend, en die tevens aangeven dat hun maatschappelijke positie niet scholier of student is. Deze laatste voorwaarde is van belang omdat anders grote groepen studenten met bijbaantjes in de analyses terecht komen. Schoolverlaters die in het MBO$\mathrm{BBL}$ instromen en schoolverlaters die in het $\mathrm{MBO}-\mathrm{BBL}$ doorstromen naar een hoger niveau worden wel tot de beroepsbevolking gerekend.

Hierbij is een belangrijke kanttekening op zijn plaats. Schoolverlaters die slagen voor het $\mathrm{VMBO}$ examen en schoolverlaters die slagen voor een BOL of BBL niveau I examen hebben weliswaar een diploma behaald, en zijn dus formeel gediplomeerden. Echter, indien zij op dit moment voor de arbeidsmarkt kiezen, en dit niet in het kader van een opleiding binnen het $\mathrm{MBO}-\mathrm{BBL}$ doen, vallen ze volgens de gangbare definitie ${ }^{\mathrm{r} 2}$ onder de zogenaamde voortijdige schoolverlaters (VSV). Omdat ze niet beschikken over een startkwalificatie worden ze niet geacht de arbeidsmarkt te betreden. Omdat echter een niet onbelangrijk deel wel doorstroomt naar de arbeidsmarkt worden ze in de komende analyses wel meegenomen. De schoolverlaters van de HAVO en de VWO worden in dit hoofdstuk niet behandeld. Dit omdat slechts een klein deel van hen doorstroomt naar de arbeidsmarkt en omdat een deel van de indicatoren niet voor deze onderwijstypen beschikbaar is. Deze indicatoren zijn niet altijd beschikbaar omdat het accent in de HAVO/VWO vragenlijst op de doorstroom naar het vervolgonderwijs ligt en niet alle arbeidsmarktvragen gesteld zijn.

\section{Allocatie}

Een succesvolle intrede op de arbeidsmarkt wordt niet alleen bepaald door de werkzekerheid. Het soort werk dat men heeft en de inhoud van de functie bepalen in hoeverre schoolverlaters de mogelijkheid hebben om hun kennis en vaardigheden te benutten. Daarnaast bepalen de

I2. Volgens de officieel gehanteerde definitie worden voortijdige schoolverlaters gezien als jongeren tussen de I2 en 23 jaar die zonder startkwalificatie (een diploma op minimaal $\mathrm{HAVO}$ - of $\mathrm{MBO}_{2}$-niveau) ten minste een maand zonder geldige reden hebben verzuimd om onderwijs te volgen en/of niet meer bij een onderwijsinstelling als deelnemer staan ingeschreven. 
inhoud en het niveau van het werk de financiële vergoeding die hier tegenover staat. Niet alleen de werkzekerheid maar ook de kwaliteit van werk heeft invloed op een succesvolle overgang van onderwijs naar arbeidsmarkt. Ondanks dat het bij gediplomeerde schoolverlaters en afgestudeerden vaak om startfuncties gaat, mag men ervan uitgaan dat de kwaliteit van het werk toeneemt naarmate de gevonden baan beter aansluit op de gevolgde opleiding voor wat betreft richting en vooral niveau. Figuur 5.I6 laat zien hoe goed de betaalde werkzaamheden van schoolverlaters aansluiten bij hun afgeronde opleiding voor zover het (I) het opleidingsniveau en (2) de opleidingsrichting betreft.

Van alle schoolverlaters heeft iets meer dan driekwart een baan op minimaal het eigen (onderwijs-) niveau. Dit is vergelijkbaar met het cijfer van afgelopen jaren. Afgestudeerden van het $\mathrm{HBO}$ en de gediplomeerde schoolverlaters van het VMBO werken het vaakst (beide in $85 \%$ van de gevallen) in een functie die minimaal gelijk is aan hun eigen niveau. Voor de uitstroom van het $\mathrm{HBO}$ is dit goed te noemen, voor de werkende VMBO-ers wordt dit met name veroorzaakt door het lage onderwijsniveau. Er zijn met andere woorden weinig banen waar geen enkele kwalificatie voor vereist is. Hierdoor zijn voor alle VMBO sectoren de percentages vrijwel gelijk. Binnen de BOL is er een duidelijk onderscheid tussen de lagere en de hogere opleidingsniveaus. Hoe lager het onderwijsniveau, hoe minder vaak men op minimaal het eigen niveau werkzaam is. Op BOL niveau 3 en 4 zijn het met name de schoolverlaters van de sector gedrag en maatschappij die op eigen niveau werkzaam zijn. Wat verder op valt is dat op BOL niveau 2 vier van de tien werkenden met een economisch gerichte opleiding een baan hebben onder hun niveau.

Ook voor de werkende uitstroom uit de BBL geldt dat ze vaker op minstens hun eigen niveau werken naarmate het opleidingsniveau hoger is. Binnen BBL niveau I heeft $46 \%$ een functie op niveau, van de gediplomeerden van niveau 4 is dit maar liefst $87 \%$. Binnen de HBO sectoren zijn het de afgestudeerden van de lerarenopleidingen en de afgestudeerden met een technische opleiding die het vaakst een functie hebben op (minimaal) eigen niveau. Omdat lerarenopleidingen per definitie voor één specifiek (HBO-) beroep opleiden en er al enige jaren sprake is van een lerarentekort is dit percentage te verwachten voor de sector onderwijs. De krapte op de arbeidsmarkt voor technici wordt door het hoge percentage voor deze sector bevestigd. Zowel in het $\mathrm{HBO}$ als in het WO scoren de afgestudeerden van de sector gedrag en maatschappij relatief laag als het gaat om het hebben van een functie op minimaal eigen niveau. Binnen het WO scoren daarnaast de taal en cultuur afgestudeerden uitzonderlijk laag.

Naast het niveau van de functie is ook de richting van de gevonden baan van belang voor de kwaliteit van het werk. Om inzicht hierin te krijgen is gekeken naar de door de werkgever vereiste opleidingsrichting. De voor de functie vereiste opleidingsrichting zegt iets over de mate waarin de gediplomeerde werkzaamheden heeft die binnen het beroependomein vallen waarvoor hij of zij is opgeleid. Van dit 'eigen' beroependomein is sprake wanneer voor de functie de eigen opleidingsrichting of een daaraan verwante opleidingsrichting vereist werd. 


\section{Figuur 5.16}

Percentage werkzame schoolverlaters met een baan op minimaal eigen niveau en percentage schoolverlaters met een baan in eigen/verwante richting, per opleidingssector

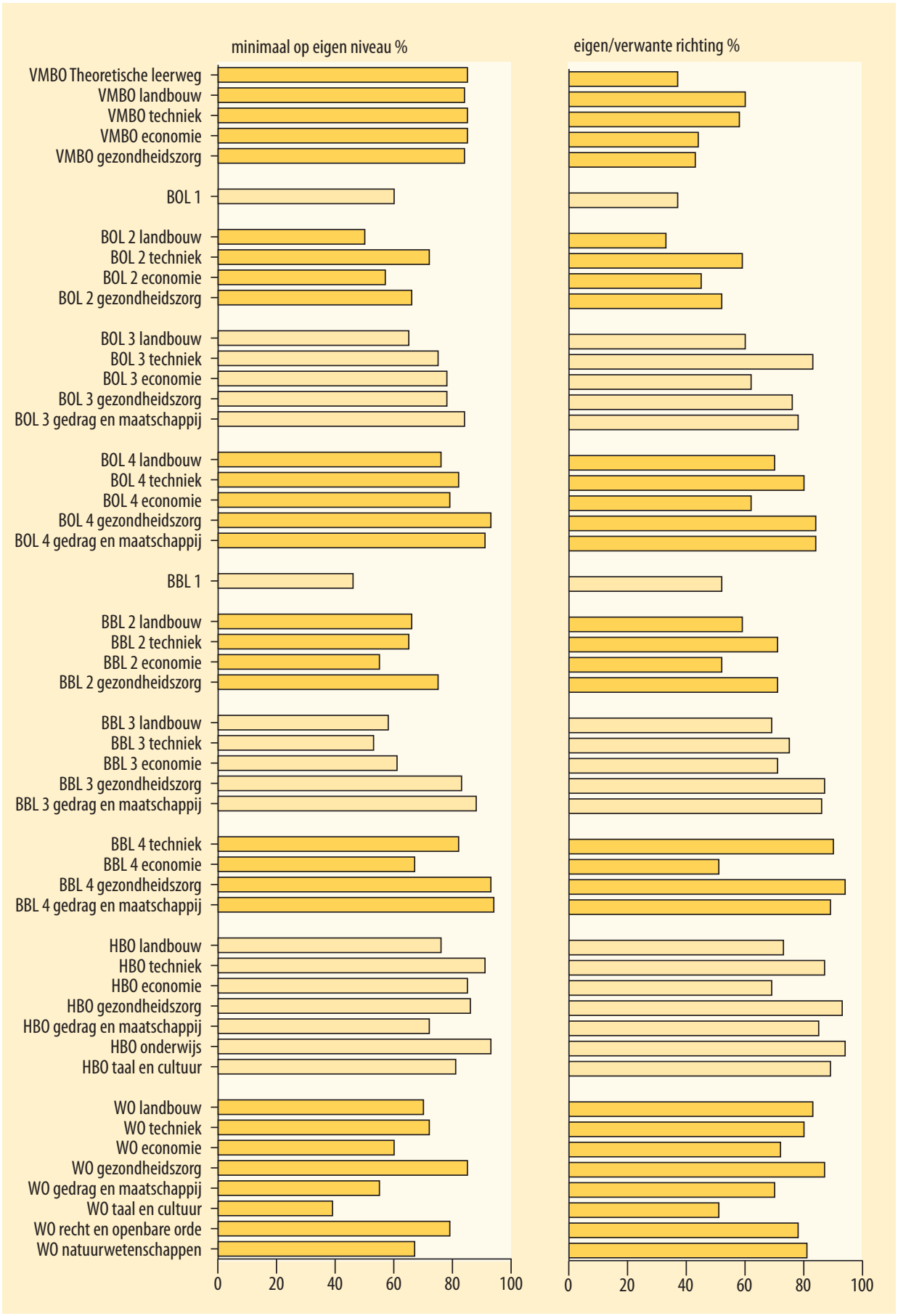

Zie ook Tabel A8.4 en Tabel A8.5 in de statistische bijlage. 
Werk vinden binnen het eigen beroependomein betekent dat de opgedane kennis en vaardigheden in de regel beter benut kunnen worden. Voor de onderwijsinstellingen is het eveneens van belang dat afgestudeerden terecht komen in beroepen waarvoor men ze heeft opgeleid. Dit laatste zal zeker gelden voor de meer beroepsgerichte opleidingen in bijvoorbeeld de sector gezondheidszorg.

De percentages werkende schoolverlaters die in hun eigen of verwante opleidingsrichting werk hebben gevonden staan ook in figuur 5.I6. Gemiddeld heeft 69\% van alle werkende schoolverlaters een baan in eigen of verwante richting. Dat is $5 \%$-punt minder dan afgelopen meetjaar. Met name HBO afgestudeerden hebben vaak $(82 \%)$ werk binnen hun eigen beroependomein. De VMBO-ers en de BOL en BBL niveau I schoolverlaters hebben duidelijk moeite om werk binnen hun eigen richting te vinden. Ook met een BOL niveau 2 opleiding lukt het slechts de helft van de gediplomeerden om een op richting aansluitende baan te vinden. Zowel op BOL niveau 3 als 4 heeft de uitstroom uit de sectoren landbouw en economie het minst vaak passend werk gevonden wat richting betreft. Ook binnen de verschillende BBL niveaus zijn het met name de werkende schoolverlaters met een economische dan wel landbouw achtergrond die het meest buiten de eigen opleidingsrichting werken. Het zelfde doet zich voor onder de afgestudeerden van het $\mathrm{HBO}$ en het WO, de economen scoren ook hier relatief slecht als het gaat om aansluiting tussen gevolgde opleiding en de functie wat richting betreft. De aansluiting is goed voor de HBO sector onderwijs, en de $\mathrm{HBO}$ en WO sector gezondheidszorg hetgeen niet verwonderlijk is omdat er binnen deze sectoren veel beroepsspecifieke opleidingen gegeven worden.

Ten slotte kan opgemerkt worden dat er een duidelijke relatie is tussen het werken op minimaal eigen niveau en het werken binnen het eigen beroependomein. Zo geeft $84 \%$ van de schoolverlaters die werk in hun eigen beroependomein hebben gevonden aan dat het om werk op minimaal eigen niveau gaat. Onder de groep schoolverlaters die buiten het eigen beroependomein werkzaam is, geeft 'slechts' $56 \%$ aan werk op minimaal eigen niveau te hebben. Afgestudeerden van een technische opleiding binnen het $\mathrm{HBO}$ en het WO hebben de beste kans om ook buiten het eigen domein op eigen niveau werkzaam te zijn. In beide gevallen werken ongeveer twee op de drie afgestudeerde technici die buiten het eigen beroependomein werken op minimaal eigen niveau. Dit resultaat spoort met eerder onderzoek onder afgestudeerden van technische opleidingen dat laat zien dat technici aan het eind van hun studie een relatief hoog niveau van academische competenties ${ }^{13}$ (bijvoorbeeld 'leervermogen') bezitten. Het relatief hoge niveau van hun academische competenties maakt hen aantrekkelijk voor werk buiten het eigen beroependomein. Dit wordt nog versterkt door het feit dat hun technische vakkennis relatief vaak te gebruiken is buiten het eigen beroependomein.

Een meer directe indicatie van de waarde van de opleiding als voorbereiding op de arbeidsmarkt kan worden verkregen door te kijken naar de mate waarin de werkende gediplomeerden in staat zijn om hun opgedane kennis en vaardigheden te benutten, en de mate waarin hun kennis en vaardigheden tekort schieten bij de uitoefening van hun werkzaamheden. Enkele cijfers hierover staan in figuur 5.17.

I3. Zie bijvoorbeeld Heijke, H., Meng, C., De competenties van bètatechniek afgestudeerden en hun positie op de arbeidsmarkt, Technotopics 2006, Platform Bètatechniek. 


\section{Figuur 5.17}

Percentage werkzame schoolverlaters dat aangeeft dat in de huidige functie de opgedane kennis en vaardigheden worden benut en percentage werkende schoolverlaters dat aangeeft dat in de huidige baan de opgedane kennis en vaardigheden tekort schieten

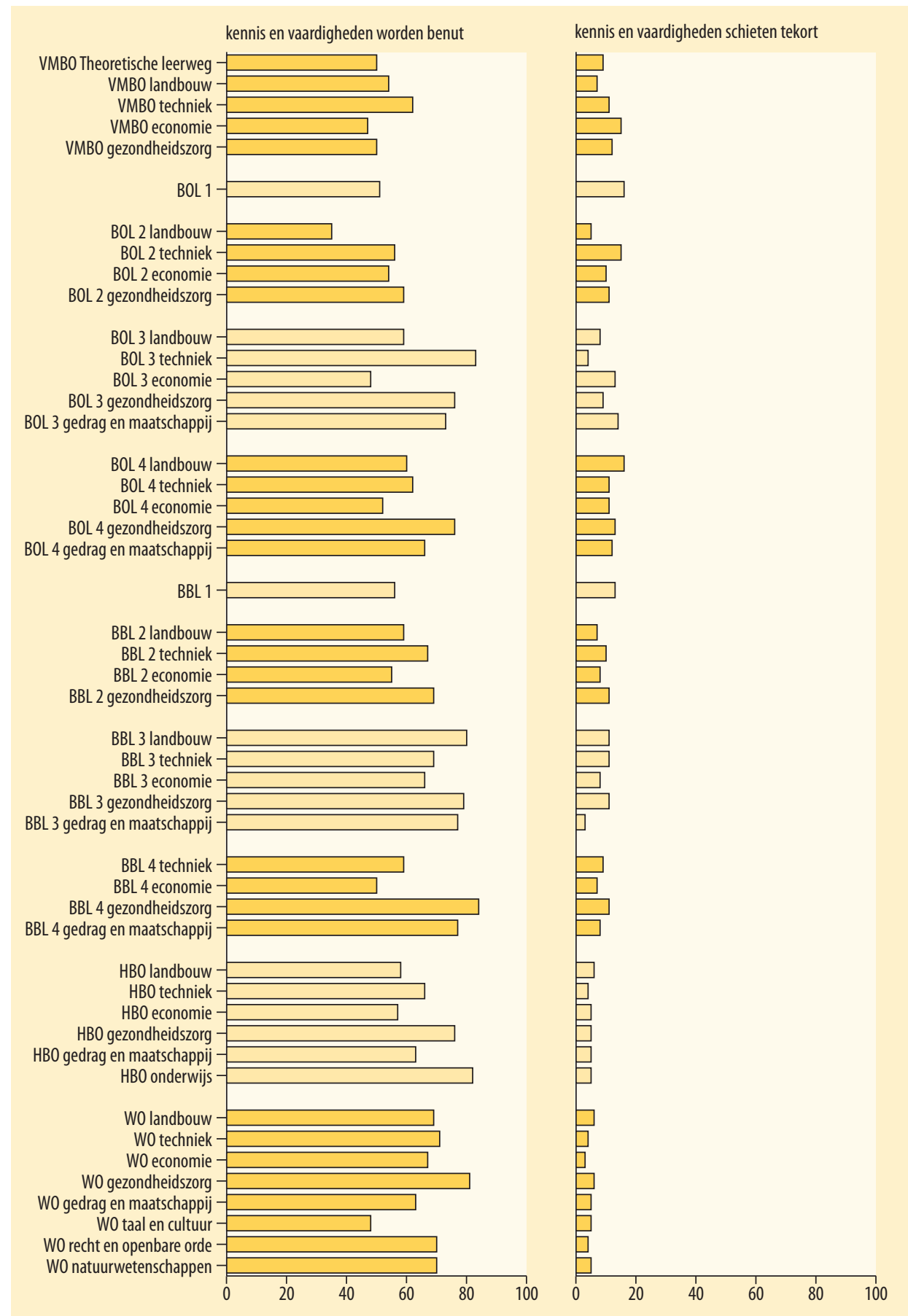

Zie ook Tabel A8.6 en Tabel A8.7 in de statistische bijlage. 
Van de werkende schoolverlaters geeft $63 \%$ aan dat hun kennis en vaardigheden in voldoende tot sterke mate benut worden. ${ }^{\text {I4 }}$ Onder de VMBO uitstroom is dit de helft. Voor de werkende BBL gediplomeerden geldt dit het vaakst, alhoewel het hoger onderwijs vrijwel eenzelfde score op dit onderdeel heeft. Binnen de verscheidene BOL niveaus geven de werkenden met een niveau 3 achtergrond dit het vaakst aan. Met een BOL niveau I opleiding wordt er relatief gezien het minst gebruik gemaakt van de kennis en vaardigheden van de schoolverlater hetgeen overeenkomt met de bevindingen over hun functieniveau. Een blik op de onderlinge niveauverschillen in de BBL levert eenzelfde beeld op. Opvallend is verder dat zowel bij de werkende schoolverlaters van de BOL als de BBL de gezondheidszorg gediplomeerden het meest tevreden zijn over de benutting van hun kennis en vaardigheden in hun functie.

Ook in het hoger onderwijs hebben de afgestudeerden uit de sector gezondheidszorg van zowel het $\mathrm{HBO}$, als het $\mathrm{WO}$ functies waarbij hun kennis en vaardigheden goed benut worden. Dit geldt eveneens voor de $\mathrm{HBO}$ sector onderwijs. Wat betreft genoemde benutting zijn de werkende HBO-economen en WO-taal en cultuur iets minder goed terecht gekomen. Vooral de WO-ers van de sector taal en cultuur scoren op dit onderdeel relatief laag.

Bijna één op de tien werkende gediplomeerden vindt dat zijn of haar kennis en vaardigheden voor de huidige werkzaamheden tekort schieten. Hierbij is er geen verschil tussen de schoolverlaters die binnen het eigen domein werken en degenen die buiten het eigen beroependomein werken. In het hoger onderwijs is dit $5 \%$, in de overige onderwijssectoren liggen de percentages rond de II\%. Terwijl VMBO-ers formeel nog niet geschikt zijn voor de arbeidsmarkt vindt ook hier maar II\% dat ze niet over de benodigde kennis en vaardigheden beschikken. Zowel binnen de BOL als de BBL vinden de schoolverlaters van het laagste niveau, niveau I, het vaakst dat ze niet over voldoende kennis en vaardigheden beschikken. Over de gehele linie zijn in het MBO de schoolverlaters van de sector gezondheidszorg relatief het meest ontevreden over hun competenties in het werk. De percentages tussen zowel de niveaus als de onderliggende sectoren liggen over het algemeen echter dicht bij elkaar. Dit laatste geldt zeker voor het $\mathrm{HBO}$ en het WO waar de verschillen tussen de sectoren minimaal zijn.

De geënquêteerden is daarnaast gevraagd aan te geven of ze de aansluiting tussen de gevolgde opleiding en de huidige functie goed, voldoende, matig of slecht vinden. De resultaten hiervan staan in figuur 5.18 vermeld. Het per opleidingssector gepresenteerde cijfer geeft aan welk deel van de betaald werkzame gediplomeerde schoolverlaters deze aansluiting goed of voldoende vindt. Zowel onder de $\mathrm{HBO}$ - als de WO-afgestudeerden vindt $78 \%$ dat de aansluiting tussen de gevolgde opleiding en de huidige functie goed of voldoende is. Vanuit de BBL vindt zelfs $83 \%$ dit. Onder de VMBO schoolverlaters en de BOL schoolverlaters is dit percentage iets lager (70\% respectievelijk $75 \%)$.

I4. Onder de schoolverlaters die binnen het eigen domein werken is dit zelfs $71 \%$. 
Figuur 5.18

Percentage werkzame schoolverlaters dat de aansluiting tussen opleiding en werk als goed of voldoende beoordeelt

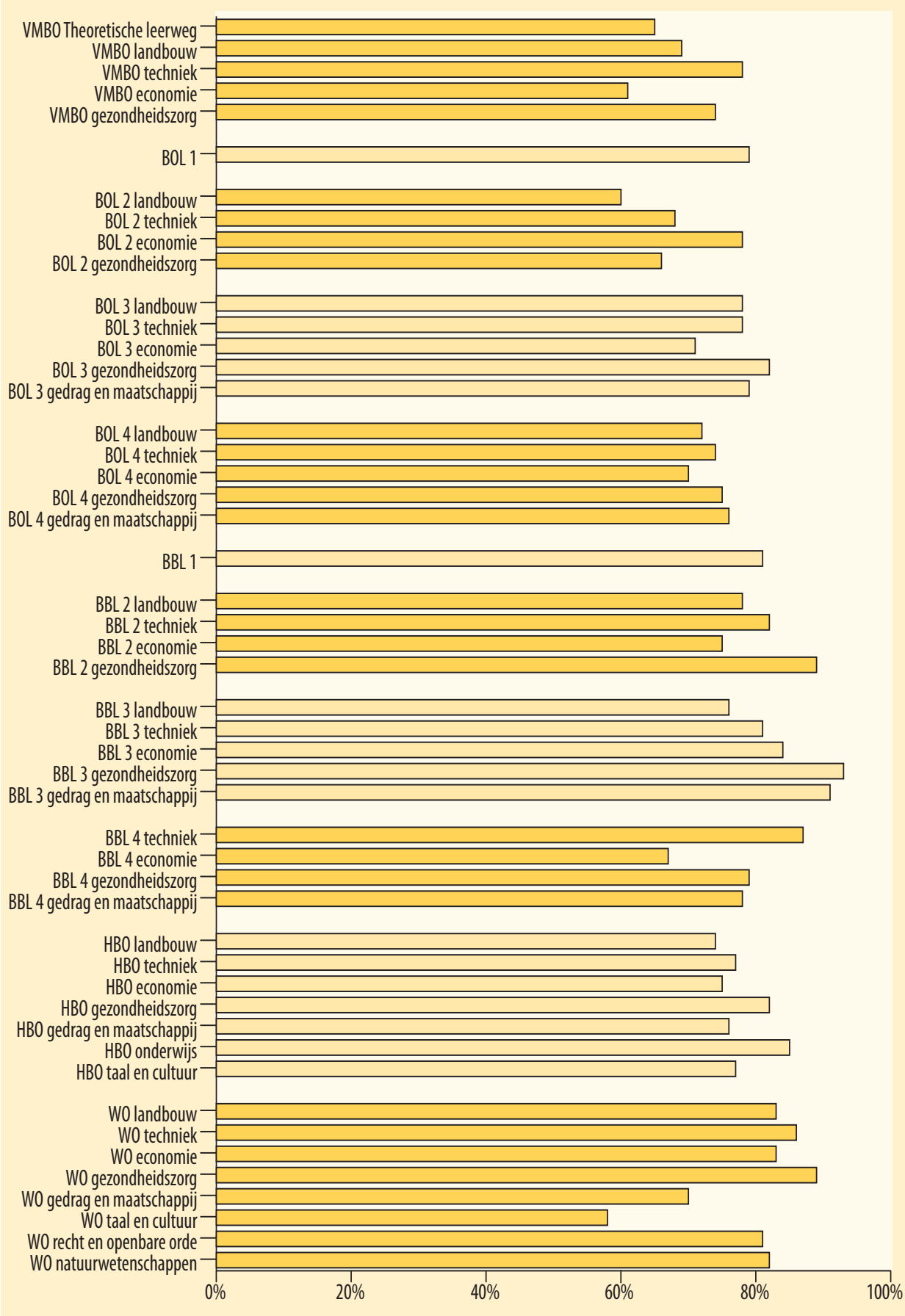

Zie ook Tabel A8.8 in de statistische bijlage. 


\section{Figuur 5.19}

Percentage werkzame schoolverlaters dat tevreden is met huidige functie

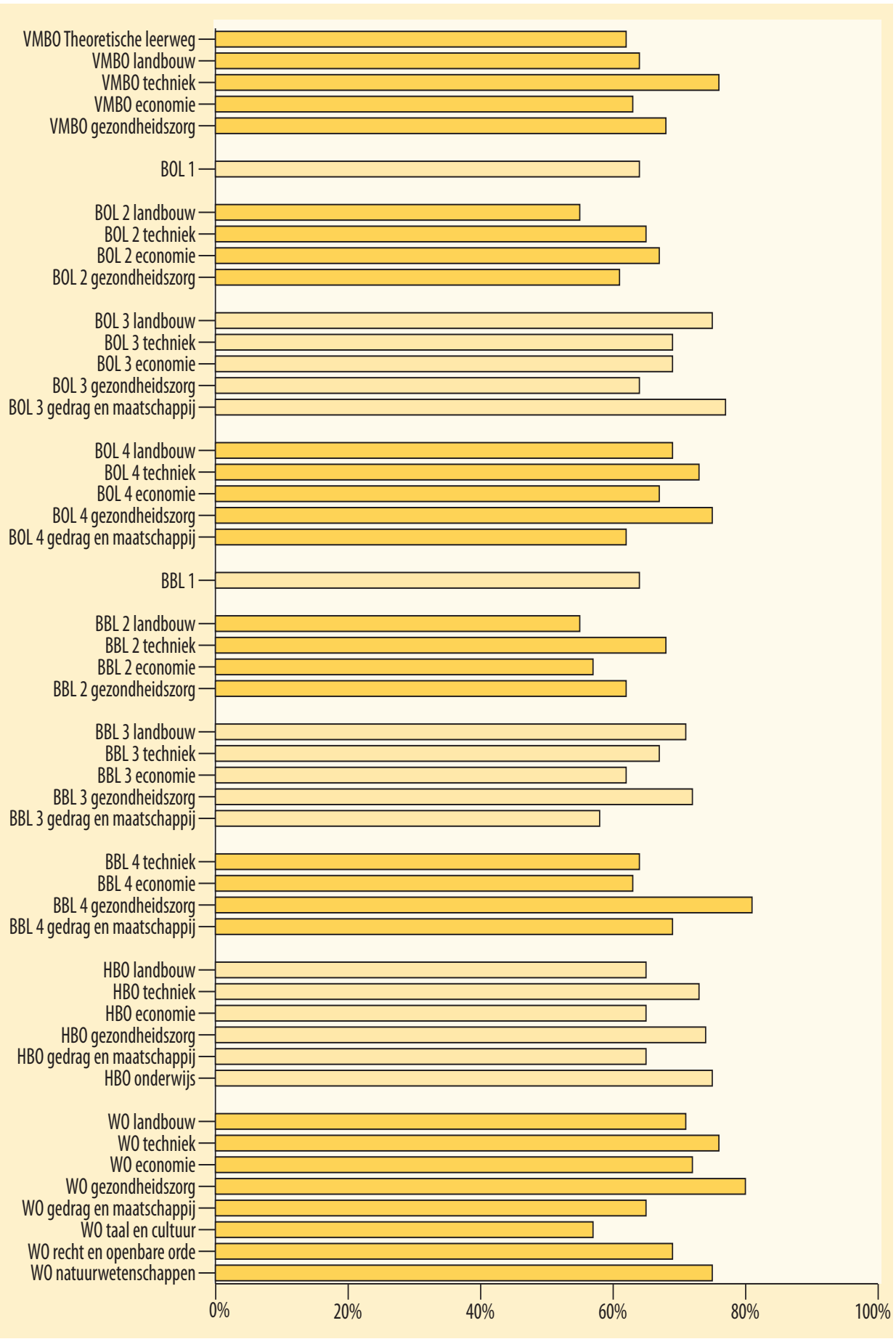

Zie ook Tabel A8.9 in de statistische bijlage. 
De werkende BOL schoolverlaters met een opleiding uit de sector gezondheidszorg van BOL niveau 3 en 4 zijn relatief tevreden over de aansluiting met hun functie, op niveau 2 zijn ze juist relatief ontevreden. Op dit niveau zijn het de schoolverlaters van de sector economie die de aansluiting goed vinden terwijl respondenten met een economische opleiding van niveau 3 of 4 weer juist van mening zijn dat de aansluiting vaak matig tot slecht is. De BBL schoolverlaters zijn meer tevreden over de aansluiting met hun functie hetgeen wellicht te maken heeft met het duale karakter van dit type onderwijs. In het algemeen geldt dat voor dit type onderwijs de schoolverlaters met een zorgopleiding iets vaker tevreden zijn met de studie tussen werk en aansluiting dan de andere BBL-ers.

Op HBO niveau zijn het de afgestudeerden van de sectoren onderwijs en gezondheidszorg die het vaakst van mening zijn dat de aansluiting goed of voldoende is. Op WO niveau springt met name de sector taal en cultuur er op dit aspect negatief uit.

Niet verrassend vinden we dat schoolverlaters die werken in het eigen beroependomein, vaker met de aansluiting opleiding-werk tevreden zijn. Zo is maar liefst $83 \%$ van de schoolverlaters die in het eigen beroependomein werken en 'slechts' $63 \%$ van de schoolverlaters die buiten het eigen beroependomein werken tevreden met de aansluiting.

Om inzicht te krijgen in de allocatiefunctie van het onderwijs worden ten slotte in figuur 5.19 enkele cijfers getoond over de tevredenheid van de werkzame schoolverlaters met hun functie. Gemiddeld is $68 \%$ van de schoolverlaters (zeer) tevreden met de huidige functie hetgeen iets minder is (3\%punt) dan afgelopen jaar. De WO afgestudeerden zijn het meest te spreken over hun baan, $70 \%$ is tevreden met zijn of haar functie. De werkenden met een BBL achtergrond zijn iets minder vaak tevreden, maar ook hier geeft gemiddeld nog $66 \%$ aan dit wel te zijn. Gemiddeld verschilt de tevredenheid slechts marginaal tussen de schoolverlaters van de verschillende opleidingsniveaus.

Van de VMBO-ers zijn het met name de technici die er in positieve zin uitspringen, $76 \%$ geeft aan tevreden te zijn. Zowel binnen de BOL als de BBL valt het op dat de landbouwopleidingen op niveau 2 een lage score hebben en op niveau 3 weer een juist relatief hoge score. Op BOL niveau 3 zijn het de schoolverlaters met een opleiding uit de gedrag en maatschappij richting die het meest te spreken zijn over hun baan, op BOL niveau 4 doen de sectoren techniek en gezondheidszorg het iets beter dan de andere opleidingssectoren. In het BBL onderwijs zijn op alle niveaus de werkenden met een economisch gerichte opleiding relatief vaak ontevreden over hun functie.

In het hoger onderwijs zijn de sectorverschillen het grootst in het WO. Van de taal en cultuur afgestudeerden vindt slechts $57 \%$ dat ze voldoende tevreden zijn over hun baan terwijl hun mede WO afgestudeerden met een gezondheidszorg achtergrond in acht van de tien gevallen tevreden zijn. Deze cijfers kunnen voor een groot deel verklaard worden door het feit dat de taal en cultuur afgestudeerden vaak in een functie werken die wat betreft niveau en richting niet aansluit op hun gevolgde opleiding.

\section{Externe rendement}

Om inzicht te krijgen in het externe rendement van het onderwijs met betrekking tot de arbeidsmarkt wordt een aantal arbeidsmarktindicatoren voor de verschillende onderwijsniveaus naast elkaar gezet. Figuur 5.20 laat eerst per opleidingssector zien welk deel van de gediplomeerde schoolverlaters zich aanbiedt op de arbeidsmarkt. Gediplomeerde schoolverlaters 
die een vervolgopleiding in het MBO-BBL volgen worden hierbij ook tot de groep anbieders geteld. Tevens toont de figuur het percentage van deze aanbieders dat ongeveer anderhalf jaar na het behalen van het diploma werkloos is.

\section{Figuur 5.20}

Percentage gediplomeerde schoolverlaters dat zich aanbiedt op de arbeidsmarkt en werkloosheidspercentage onder gediplomeerde schoolverlaters

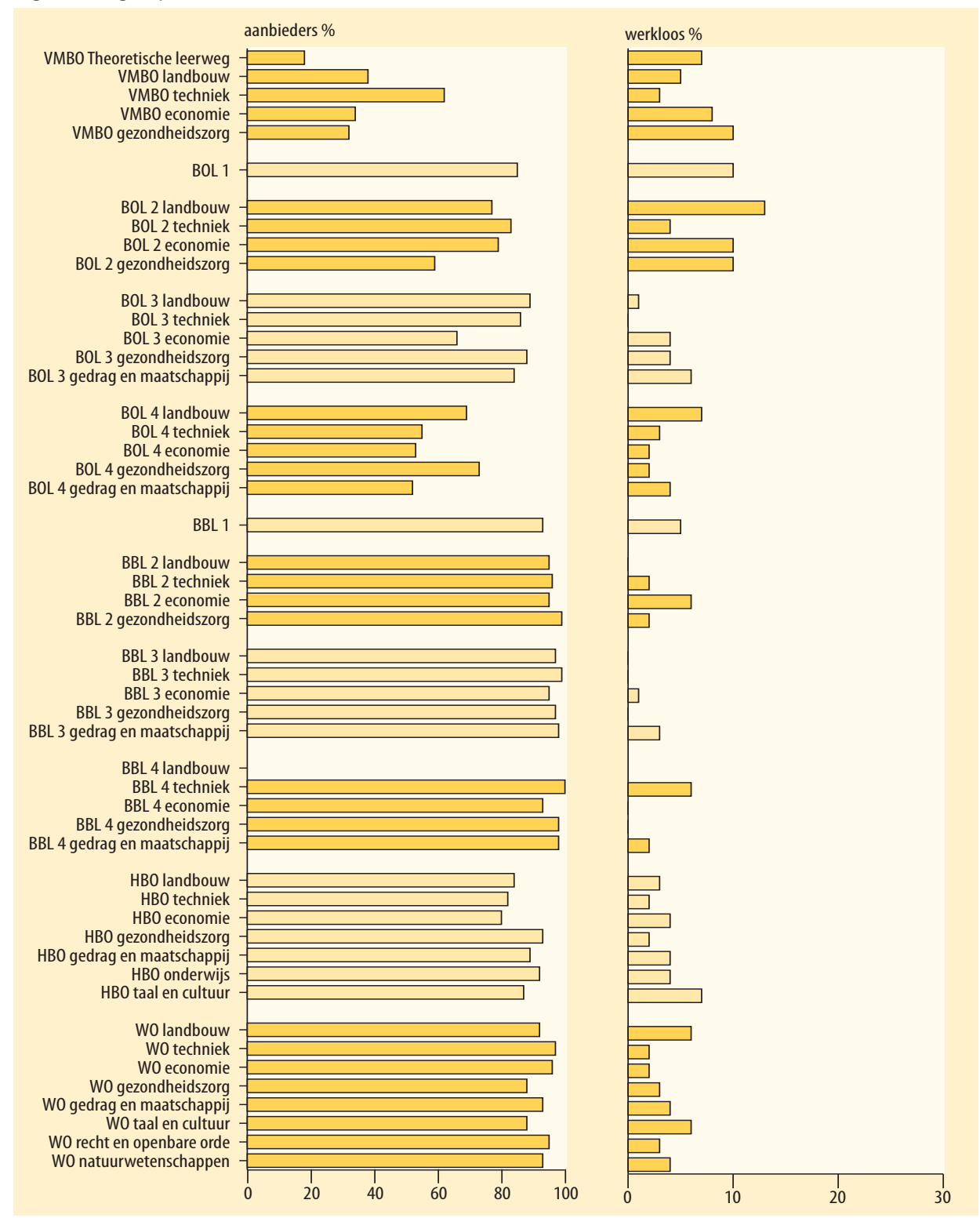

Zie ook Tabel A9.1 in de statistische bijlage.

Iets meer dan de helft $(56 \%)$ van de gediplomeerde schoolverlaters richt zich na het behalen van het diploma op de arbeidsmarkt. Uiteraard zijn de verschillen tussen de onderwijstypes groot: zo 
biedt 93\% van de afgestudeerde WO-ers zich aan terwijl dit 31\% van de VMBO-ers doet. Overigens volgt een groot deel van deze groep VMBO-ers een opleiding in het kader van het MBO-BBL (zo'n $20 \%$ ), terwijl slechts IO\% zich op de arbeidsmarkt buiten het MBO-BBL aanbiedt. Gezien het feit dat een VMBO diploma feitelijk geen startkwalificatie is, is IO\% toch nog redelijk hoog te noemen. Van de BBL uitstroom gaat vrijwel iedereen naar de arbeidsmarkt (of stroomt binnen het MBOBBL door). Hoewel gemiddeld $67 \%$ van de gediplomeerde BOL respondenten zich aanbiedt zijn de verschillen tussen de niveaus en de onderwijssectoren redelijk groot binnen de BOL. Zo biedt bijna 90\% van de BOL niveau 3 landbouw gediplomeerden zich aan terwijl van bijvoorbeeld, de gedrag en maatschappij niveau 4 uitstroom slechts $52 \%$ de arbeidsmarkt heeft betreden. In het $\mathrm{HBO}$ en het WO zijn de verschillen tussen de sectoren iets minder groot.

De goede economische situatie in Nederland weerspiegelt zich in de werkloosheidscijfers onder de gediplomeerde schoolverlaters. Ten opzichte van het vorig meetjaar is de gemiddelde werkloosheid onder alle zich aanbiedende schoolverlaters (met uitzondering van die van het $\mathrm{VMBO}$ ) gedaald, en wel van $6 \%$ naar $4 \%$. De werkloosheid is het hoogst onder de VMBO schoolverlaters (6\%) en het laagst onder de BBL uitstroom (2\%). Op VMBO niveau hebben de gediplomeerden van de sector gezondheidszorg moeite met het vinden van een baan, IO\% van hen is werkloos. De VMBO technici vergaat het een stuk beter op de arbeidsmarkt, van hen is slechts $3 \%$ werkloos op enquêtemoment. Binnen de BOL zijn er redelijk grote verschillen tussen de onderwijsniveaus. Van de BOL niveau I opleidingen is gemiddeld één op de tien schoolverlaters nog werkzoekend. Onder de niveau 4 gediplomeerden is de werkloosheid slechts $3 \%$. Wel valt op dat de hoogconjunctuur op alle BOL niveaus een positieve uitwerking heeft gehad t.a.v. het werkloosheidspercentage. Ten opzichte van vorig meetjaar is de werkloosheid bij de schoolverlaters van BOL niveau I gedaald van $22 \%$ naar $\mathrm{IO} \%$, bij BOL niveau 2 van II\% naar $8 \%$, bij BOL niveau 3 van $7 \%$ naar $4 \%$, en bij BOL niveau 4 van $6 \%$ naar $3 \%$. Binnen ieder afzonderlijk BOL niveau zijn het met name de technici die het minst moeite hebben met vinden van een baan. Binnen de andere onderwijssoorten is de werkloosheid laag en zijn de verschillen klein tussen de onderliggende sectoren. Zowel binnen het $\mathrm{HBO}$ als het WO lijken de afgestudeerden van de sector taal en cultuur het minst te profiteren van de krapte op de arbeidsmarkt.

Zoals uit figuur 5.20 blijkt heeft op het moment van enquêteren een groot deel van de schoolverlaters een betaalde baan. Waarschijnlijk hebben ze echter niet allemaal deze baan meteen na afstuderen gekregen of hebben ze meerdere banen gehad met tussenliggende perioden van werkloosheid. Figuur 5.2I geeft daarom een tweede indicatie van het rendement van een opleiding: de duur van de werkloosheid voordat men de eerste baan vond. Meer in detail laat figuur 5.2I het percentage van de schoolverlaters zien die minimaal vier maanden werkloos waren voordat zij de eerste baan vonden.

Gemiddeld is 7\% (meting 2006: IO\%) van de gediplomeerde schoolverlaters direct na het behalen van het diploma vier maanden of langer werkloos. Ook hiermee is de verbeterde conjunctuur zichtbaar. Deze intredewerkloosheid is het hoogst onder de opgeleiden van het HBO $(8 \%)$ en het WO (13\%). Deze hogere intredewerkloosheid ten opzichte van de andere onderwijsniveaus wordt deels verklaard door het vereiste functieniveau. Voor het annemen van een $\mathrm{HBO}$ of WO functie zal gemiddeld genomen langer worden nagedacht dan over het aannemen van een functie op een lager niveau. Voor de afgestudeerde gaat het hierbij niet alleen om deze eerste baan maar moet er ook een initiële carrierestap gezet worden die gevolgen kan hebben voor latere banen en mogelijkheden. 


\section{Figuur 5.21}

Percentage gediplomeerde schoolverlaters dat voorafgaand aan de eerste baan minimaal 4 maanden werkloos was

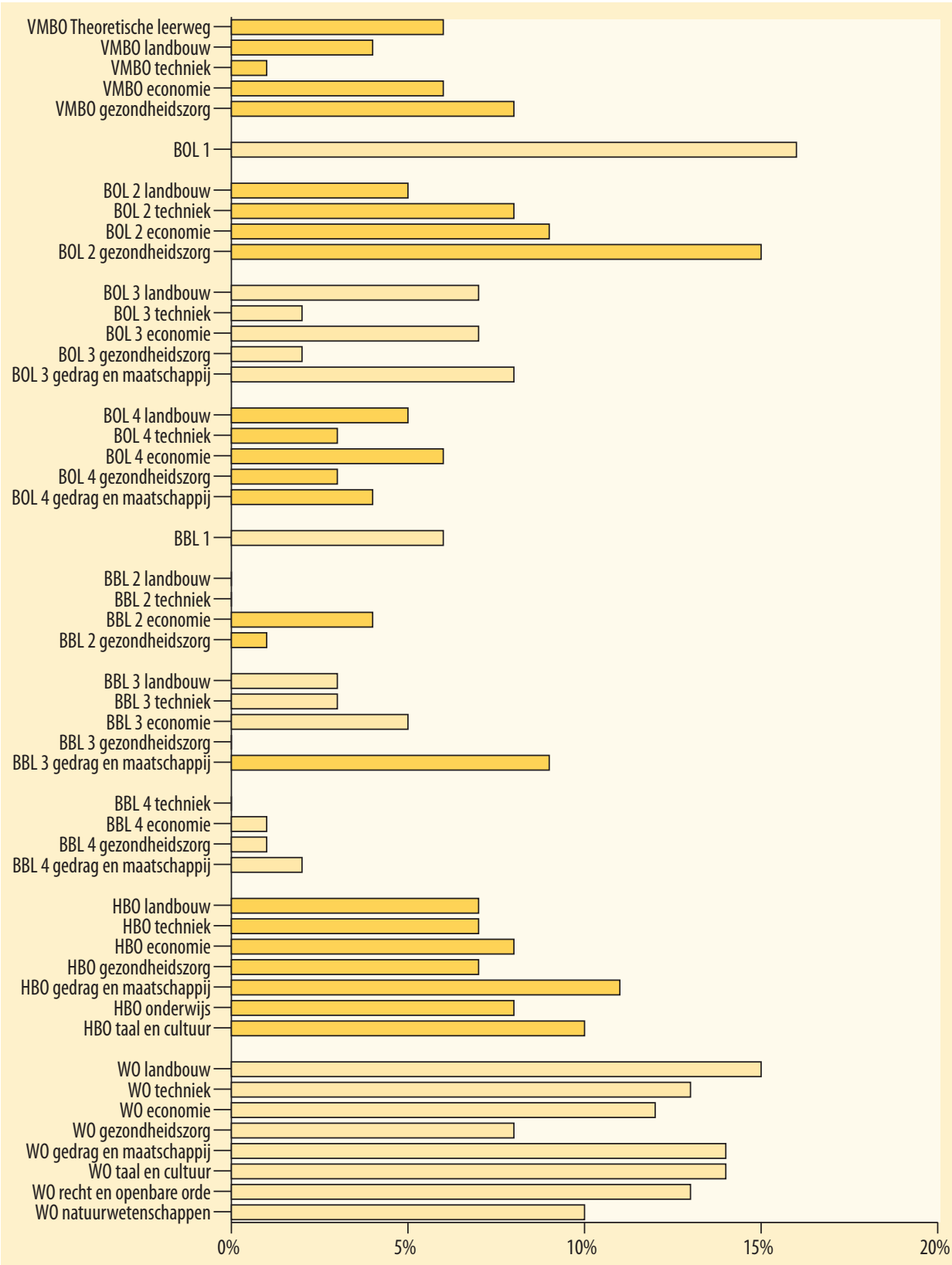

Zie ook Tabel A9.2 in de statistische bijlage.

Daarnaast kan het al dan niet aannemen van een functie betekenen dat men bijvoorbeeld moet verhuizen, iets wat op $\mathrm{MBO}$ en VMBO niveau minder vaak zal voorkomen (zie ook hoofdstuk 
7). Van de gediplomeerde VMBO uitstroom moest $5 \% 4$ maanden of langer wachten op een baan. Onder de werkzoekende gediplomeerden van het duale MBO traject was dit zelfs maar $2 \%$.

Binnen het $\mathrm{VMBO}$ waren de gediplomeerden van de sector gezondheidszorg iets langer op zoek naar de eerste baan dan de overige VMBO-sectoren. De uitstroom van de korte BOL opleidingen is direct na het afstuderen duidelijk langer werkloos geweest dan hun studiegenoten van de langere BOL opleidingen. Met name werkzoekenden met een niveau 2 gezondheidszorgopleiding hebben vaak 4 maanden of langer moeten zoeken naar hun eerste baan. Wellicht ook door het duale karakter van de BBL is slechts een klein deel langer dan drie maanden werkloos geweest vlak na het behalen van het diploma. Behalve voor de gedrag en maatschappij opleidingen van niveau 3 zijn de percentages over het algemeen laag in deze onderwijssoort. In het $\mathrm{HBO}$ is de zoekduur voor de verschillende sectoren ongeveer gelijk. Onder de WO afgestudeerden zijn het de opleidingssectoren gezondheidszorg en natuurwetenschappen waar men het minst vaak langer dan drie maanden werkloos is geweest alvorens in de eerste baan werd begonnen.

Het externe rendement van het onderwijs met betrekking tot de arbeidsmarkt wordt niet alleen bepaald door de vraag of men werk heeft maar ook door de vraag in hoeverre er sprake is van werkzekerheid. Om hier enig zicht op te krijgen staan in figuur 5.22 enkele cijfers over het hebben van een flexibele aanstelling en het hebben van een deeltijdaanstelling. Onder een flexibele aanstelling wordt verstaan een aanstelling als uitzendkracht, oproepkracht e.d. of een tijdelijke aanstelling. Van een deeltijdaanstelling is sprake wanneer iemand een aanstelling van 32 of minder uur per week heeft.

Van alle schoolverlaters heeft vier van de tien een flexibele aanstelling. De werkende VMBOers hebben met $56 \%$ de minste werkzekerheid, met name de schoolverlaters van de economische richting hebben vaak een flexibele aanstelling. In het $\mathrm{MBO}$ is er bij de BOL, behalve niveau I, weinig verschil tussen de onderliggende niveaus. De technici van BOL niveau 4 en de landbouw schoolverlaters van niveau 3 hebben een hoge werkzekerheid. 'Slechts' respectievelijk $34 \%$ en $32 \%$ heeft een flexibele aanstelling.

In de BBL is de werkzekerheid het hoogst, slechts één op de vijf gediplomeerden heeft een flexibele aanstelling. De BBL-ers van niveau 2 hebben binnen de BBL het vaakst een flexibele aanstelling. Deze hoge werkzekerheid heeft waarschijnlijk te maken met het duale karakter van de opleidingen. Vaak vloeit vanuit de leerplek een baan voort of was men al aan het werk voordat er met de opleiding gestart werd. De technici van het $\mathrm{HBO}$ hebben ten opzichte van hun $\mathrm{HBO}$ studiegenoten de hoogste werkzekerheid, slechts $30 \%$ heeft geen vaste aanstelling. Ook de WO economen hebben veel werkzekerheid, een kwart van hen heeft een flexibele aanstelling. De in bijlage 3 gepresenteerde cijfers voor de jaren 1996-2007 laten overigens voor alle onderwijsniveaus over de jaren heen een duidelijke stijging van het aantal flexibele aanstellingen zien. Had bijvoorbeeld in de jaren 1996 tot 2002 ongeveer een op de tien afgestudeerden van het WO een flexibele aanstelling, nu is dit rond de een op de twee. Vergelijkbare ontwikkelingen zijn ook voor de afgestudeerden van het $\mathrm{HBO}$ en het $\mathrm{MBO}$ zichtbaar. Met het einde van de sterke economische groei in de eerste jaren van het nieuwe millennium lijkt ook hier een einde aan het tijdperk van 'vaste contract' voor net afgestudeerden gekomen te zijn. 


\section{Figuur 5.22}

Percentage werkzame schoolverlaters met een flexibele aanstelling en percentage werkzame schoolverlaters met een deeltijdaanstelling

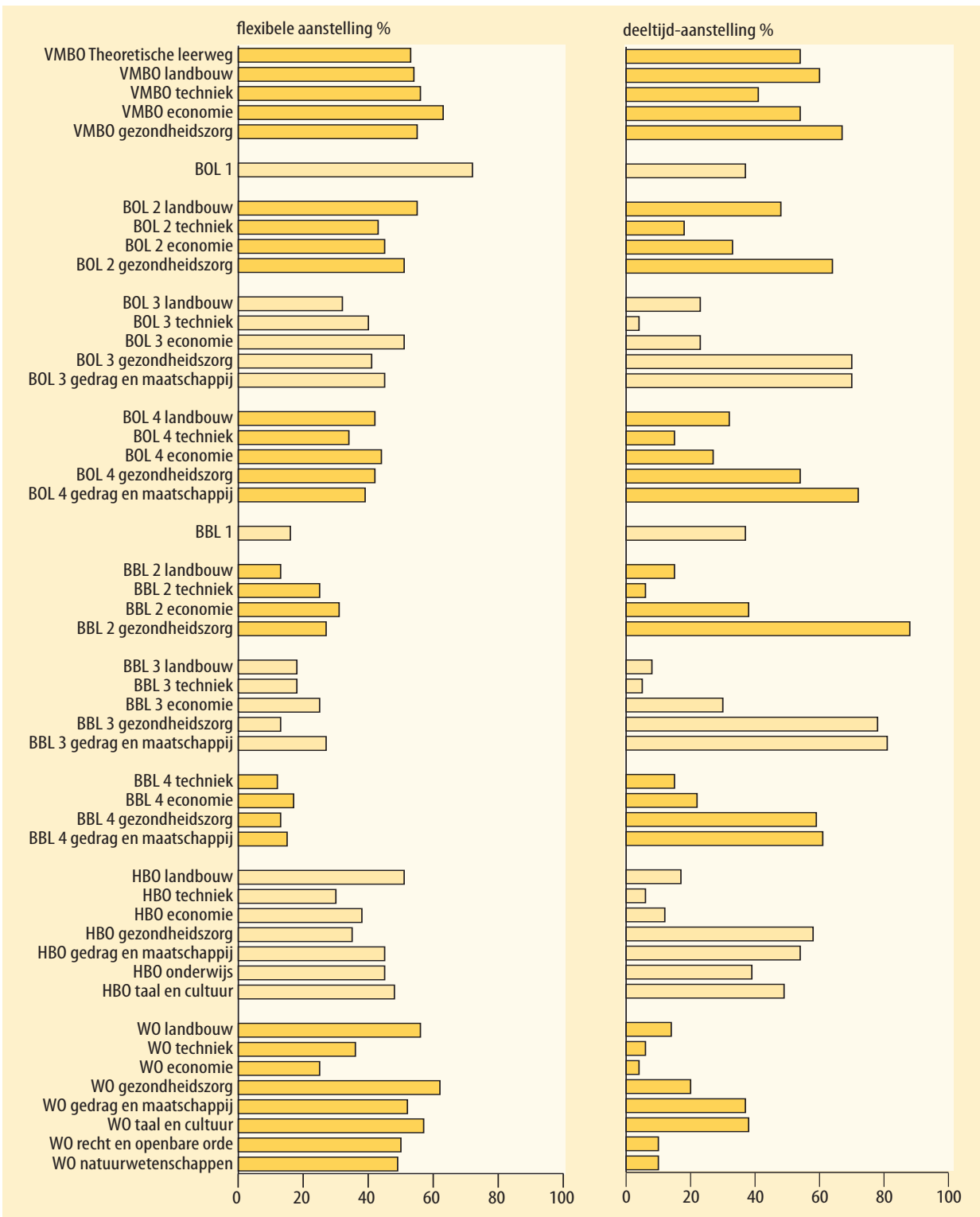

Zie ook Tabel A9.5 en Tabel A9.7 in de statistische bijlage.

In het tweede deel van figuur 5.22 staan de percentages werkenden met een deeltijdaanstelling. Bijna vier van de tien schoolverlaters hebben een deeltijdaanstelling. Onder de vrouwelijke schoolverlaters is dit overigens aanzienlijk hoger, namelijk $53 \%$. Hoe hoger het genoten onderwijsniveau, hoe lager het percentage werkenden met een deeltijd baan. Onder de $\mathrm{VMBO}$-ers is dit $53 \%^{15}$, onder de $\mathrm{WO}$ afgestudeerden slechts $20 \%$. Tussen de onderliggende

I5. Het relatief hoge percentage onder de schoolverlaters van het $\mathrm{VMBO}$ is deels te verklaren door instroom in het MBO-BBL. 
VMBO sectoren zijn er grote verschillen. Zo werkt $67 \%$ van de schoolverlaters uit de sector gezondheidszorg niet full-time, onder de technische VMBO-ers is dit slechts $41 \%$. Gemiddeld werken $40 \%$ van de BOL schoolverlaters in een deeltijd baan. Wat opvalt is dat op alle niveaus de technici relatief vaak een full-time baan hebben. De uitstroom van de sectoren gedrag en maatschappij en gezondheidszorg werkt daarentegen weer vaak in een deeltijdbaan. Een vergelijkbaar beeld als bij de BOL doet zich voor onder de werkende schoolverlaters van de BBL. Ook voor het $\mathrm{HBO}$ geldt dat de afgestudeerde technici bijna altijd full-time werken (94\%). $\mathrm{HBO}$-ers met een gezondheidszorg opleiding werken daarentegen vaak in deeltijd functies $(58 \%)$. In het WO springen met name de sectoren taal en cultuur en gedrag en maatschappij er uit als het gaat om het aandeel werkenden in deeltijd banen.

Een derde indicator voor de kwaliteit van het werk is de beloning. Overal zijn de nominale startsalarissen ten opzichte van het vorig meetjaar rond de 3\% gestegen. Reëel heeft hiermee nauwelijks verandering ten opzichte van het vorig meetjaar plaatsgevonden. In figuur 5.23 staan per opleidingssector de gemiddelde bruto uurlonen vermeld. Het gemiddelde uurloon stijgt naarmate het behaalde opleidingsniveau hoger is. De VMBO schoolverlaters verdienen gemiddeld $€ 4,83$ per uur. Ondanks dat de BOL en BBL niveau I werkenden geen startkwalificatie hebben, verdienen ze toch nog $€ 7,85$ respectievelijk $€ 9$,००. Als kanttekening moet hier opgemerkt worden dat vooral in de groep werkende schoolverlaters van BBL niveau I een relatief grote groep 'oudere' werknemers zit die in de loop van hun carrière alsnog een MBO-niveau I diploma behalen. ${ }^{16}$ Dat is aanzienlijk meer dan de VMBO-ers met een baan. Binnen BOL niveau 2 zijn het de schoolverlaters met een landbouwachtergrond die ten opzichte van studiegenoten uit de andere sectoren relatief weinig verdienen namelijk $€ 6$,Io. Ook op BOL niveau 3 en 4 is het uurloon van de onderwijssector landbouw het laagst. Op niveau 3 verdienen de technici het meest, op niveau 4 de mensen met een gezondheidszorg opleiding.

Op BBL niveau verdient men meer dan de studiegenoten van de BOL. Dit wordt veroorzaakt door het duale karakter van het onderwijs en het feit dat de gemiddelde werkende BBL schoolverlater zo'n 7,5 jaar ouder is dan de (werkende) BOL schoolverlater. Op alle BBL niveaus geldt dat het hoogste uurloon verdiend wordt door mensen met een opleiding uit de sector gezondheidszorg. Ook in het WO heeft de sector gezondheidszorg $(€ \mathrm{I} 6,8)$, samen met de sector economie $(€ \mathrm{I} 6,9)$, het hoogste bruto uurloon. Evenals in het $\mathrm{HBO}$ zijn het de afgestudeerden met een gevolgde opleiding op taal en cultuur gebied (WO: $€$ I3,85; HBO: $€$ IO,I5) die aan het kortste eind trekken wat betreft beloning. Overigens laat nader onderzoek zien dat het uurloon sterk samenhangt met de vraag of men op eigen niveau werkzaam is en of men in het eigen beroependomein werkzaam is. Zo verdienen bijvoorbeeld HBO- en WOafgestudeerden die werkzaam zijn op eigen niveau ongeveer IO\% meer dan hun studiegenoten die een baan op een lager niveau hebben aangenomen. Onder schoolverlaters van het MBOBOL loopt dit verschil zelfs op tot bijna 20\% (MBO-BOL niveau 3). Ook schoolverlaters die binnen het eigen beroependomein werken verdienen duidelijk meer dan hun studiegenoten die buiten het eigen beroependomein werken.

I6. Het gemiddelde bruto uursalaris van MBO-BBL niveau I schoolverlaters die op het moment van de enquête jonger dan 30 jaar zijn, ligt duidelijk lager, namelijk bij $€ 6.85$. 


\section{Figuur 5.23}

Beloning op basis van het gemiddelde bruto uurloon van werkzame schoolverlaters

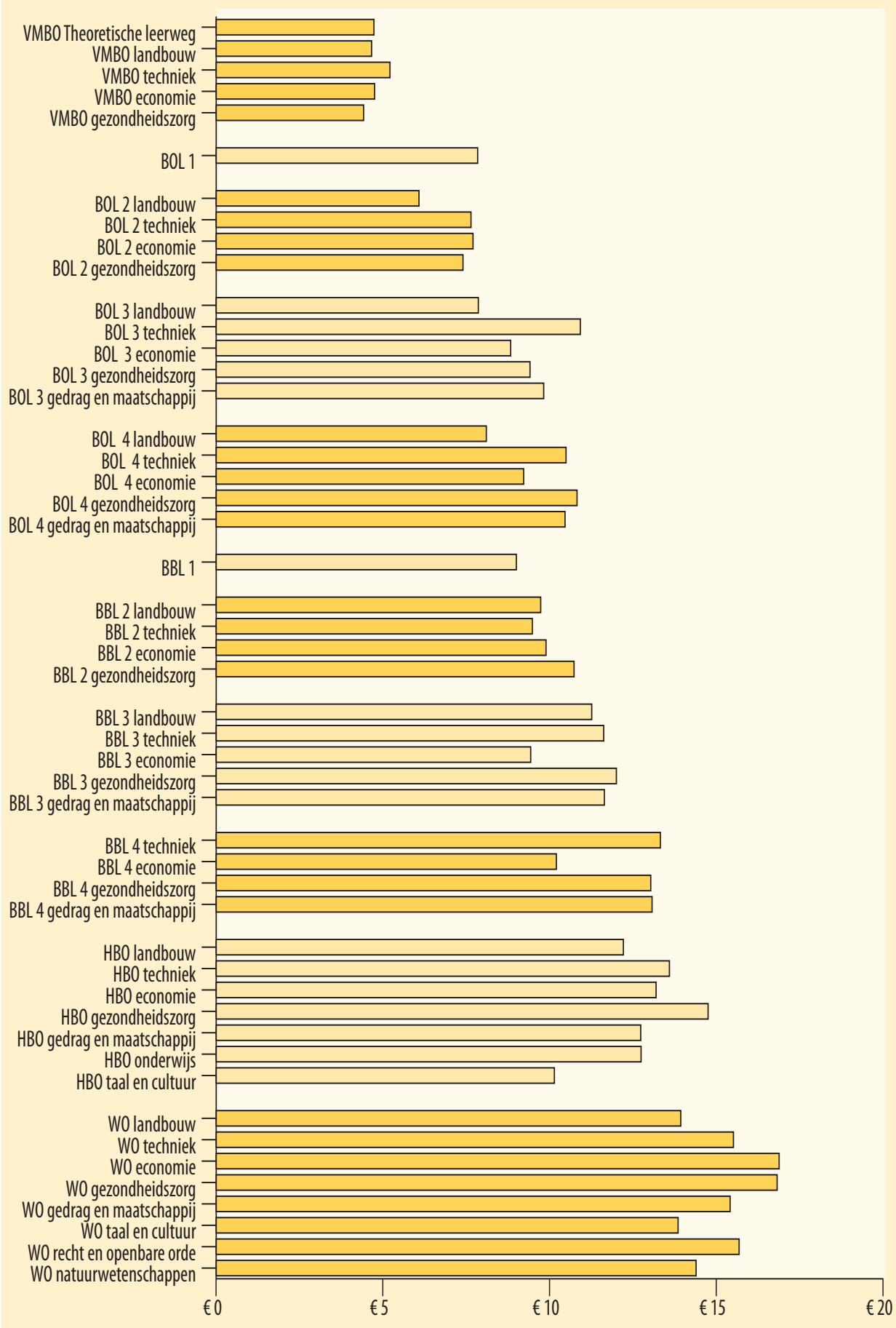

Zie ook Tabel A9.6 in de statistische bijlage. 


\section{Figuur 5.24}

Carrièreperspectieven in huidige functie: Percentage gediplomeerde schoolverlaters dat vindt goede tot heel goede carrièreperspectieven te hebben

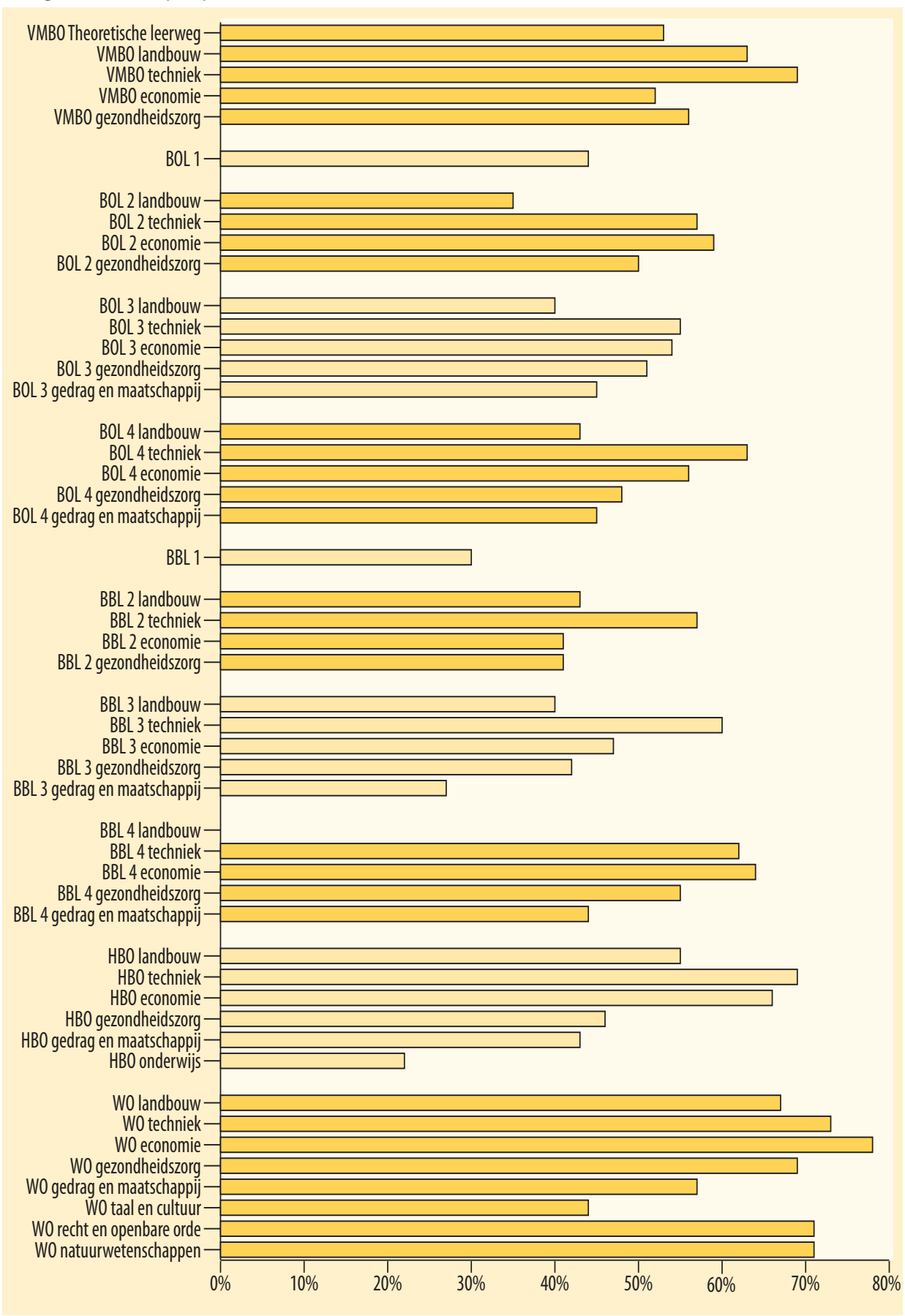

Zie ook Tabel A9.8 in de statistische bijlage. 
Een meer subjectief, maar niet onbelangrijk onderdeel, van een functie zijn de geboden toekomstperspectieven. Wat zijn de doorgroeimogelijkheden met betrekking tot werkzaamheden, salaris, promotie en persoonlijke ontplooiing? Alhoewel deze aspecten (nog) niet altijd meetbaar zijn, zal de kwaliteit van een functie toenemen naarmate de respondenten hier meer mogelijkheden zien. Tot slot van de discussie met betrekking tot het externe rendement van een opleiding geeft figuur 5.24 daarom het percentage werkende schoolverlaters weer dat van mening is dat hun huidige functie goede tot heel goede carrièreperspectieven biedt.

Iets meer dan de helft van alle werkende schoolverlaters vindt dat zijn of haar functie veel tot zeer veel carrièremogelijkheden biedt. Met name de WO afgestudeerden (66\%) zijn tevreden over dit aspect van hun werk. Ondanks dat ze geen startkwalificatie hebben zien de VMBO schoolverlaters relatief gezien ook nog veel mogelijkheden in hun werk (59\%). Dit geldt met name voor de VMBO sectoren landbouw en techniek. Deze, volgens de schoolverlaters, goede carrièremogelijkheden gelden ook voor de diverse BOL niveaus voor zover het de techniek en economie opleidingen betreft. Juist in tegenstelling met het VMBO vinden de BOL respondenten met een landbouwopleiding juist niet zo vaak dat er goede kansen liggen in hun huidige werk.

Ook in het duale onderwijs hebben de technici en de economie schoolverlaters volgens respondenten de meeste carrièremogelijkheden. In het algemeen zijn de BBL-ers echter iets minder tevreden over hun carrièrekansen dan de BOL uitstroom. De afgestudeerden van het $\mathrm{HBO}$ zijn met $54 \%$ minder vaak te spreken over hun carrièremogelijkheden dan hun WO collega's. De doorgroeimogelijkheden van de HBO leraren blijft een probleem. Ook in dit onderzoek ziet nog geen kwart van hen goede carrièremogelijkheden in de huidige functie. Deze huidige functie bestaat voor het overgrote deel uit (leraren-) functies in de onderwijssector. Van de werkende WO uitstroom zijn de economen het meest tevreden over hun mogelijkheden op het carrièrevlak, de taal en cultuurstudies doen het met $44 \%$ minder goed.

\section{Tevredenheid achteraf}

Tot slot is aan de schoolverlaters van het $\mathrm{MBO}$ en het hoger onderwijs die de arbeidsmarkt betreden de vraag voorgelegd of zij achteraf gezien opnieuw dezelfde opleiding zouden kiezen. Van alle respondenten zou $78 \%$ de opleiding opnieuw zijn gaan volgen. Dit betekent dat bijna één op de vier gediplomeerden achteraf liever een andere opleiding was gaan volgen. De minste spijt is er bij de WO afgestudeerden, $83 \%$ zou dezelfde studiekeuze maken. De $\mathrm{HBO}$ afgestudeerden zijn met $8 \mathrm{I} \%$ vrijwel dezelfde mening toegedaan. Zowel in het HBO als het WO zijn de gezondheidszorg gediplomeerden het meest tevreden met hun destijds gemaakte studiekeuze.

Binnen de BOL is de tevredenheid over de gevolgde opleiding op de niveau 3 en 4 opleidingen het grootst. $79 \%$ van de schoolverlaters met een niveau 4 opleiding zou de opleiding weer zijn gaan volgen, op niveau 3 is dit $76 \%$. De korte BOL opleidingen scoren iets minder goed met 66\% (niveau I) en 63\% (niveau 2). De respondenten met een economische opleidingsachtergrond zijn op beide niveaus het minst tevreden. In het BBL onderwijs zouden vier van de tien niveau I gediplomeerden liever een ander studie hebben gevolgd. Op de andere BBL niveaus is men meer tevreden, de BBL niveau 3 opleidingen zouden in $82 \%$ van de gevallen weer opnieuw worden gekozen. Op vrijwel alle niveaus hebben de schoolverlaters van de onderwijssector economie de meeste spijt over hun gemaakte studiekeuze. 


\section{Figuur 5.25}

Percentage werkzame schoolverlaters dat achteraf bezien dezelfde opleiding zou volgen

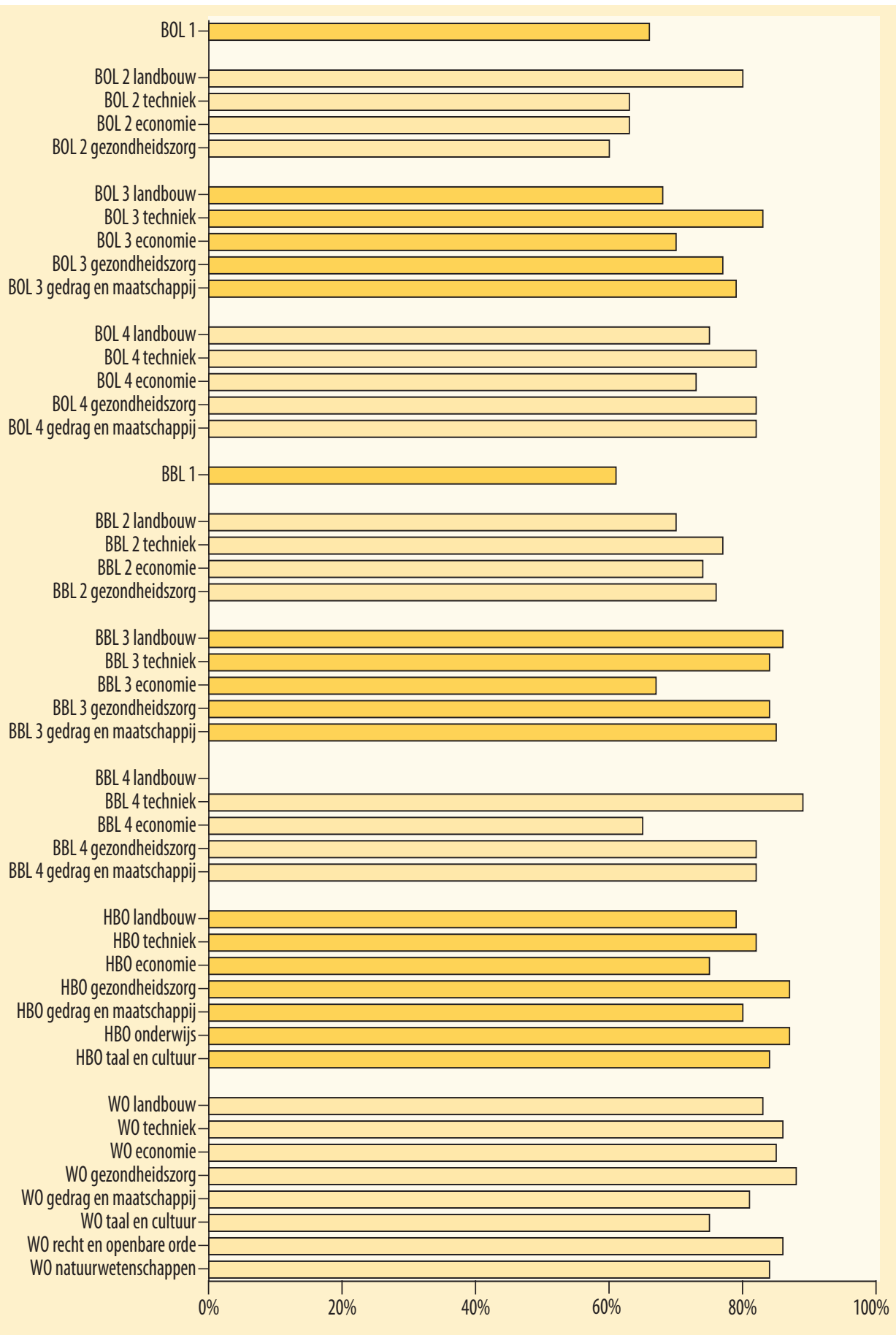

Zie ook Tabel A10.1 in de statistische bijlage. 


\section{Samenvattende totaalscores}

Op basis van een selectie van eerder in dit rapport beschreven indicatoren is voor alle vier hoofdaspecten, Kwalificatie, Selectie, Allocatie en Externe rendement, een totaalscore berekend. In tabel 6.I staan deze totaalscores ${ }^{17}$ voor de individuele onderwijssectoren weergegeven. Aan de hand van deze totaalscores wordt in dit hoofdstuk een samenvattend beeld van het gehele onderwijsveld gegeven.

\section{De kwalificatiefunctie}

De kwalificatiefunctie van het onderwijs draait om de vraag of het onderwijs de schoolverlaters afdoende heeft uitgerust met de competenties welke relevant zijn voor de doorstroming naar een vervolgopleiding of de arbeidsmarkt. De totaalscore voor dit onderdeel is gebaseerd op de vragen (I) of de opleiding een goede basis biedt om te starten op de arbeidsmarkt en (2) of de opleiding een goede basis biedt om kennis en vaardigheden verder te ontwikkelen. Voor elk van deze vragen is een score tussen de I en Io vastgesteld. Het gemiddelde van deze twee scores wordt in tabel 6.I vermeld als eindbeoordeling "kwalificatie".

De scores van het onderdeel "kwalificatie" liggen over alle onderwijssoorten niet ver uit elkaar, ze variëren van een 6,5 voor het $\mathrm{VMBO}$ tot een 7,2 voor de BBL en het WO. De VMBO theoretische leerweg scoort met een 6,I het laagste cijfer terwijl de technieksector van de BBL niveau 4 het uitzonderlijk goed doet met een 7,9 . De andere leerwegen van het VMBO hebben ook geen bijzonder goede totaalscore voor dit onderdeel. Binnen de BOL heeft de niveau 3 sector landbouw de laagste score voor het kwalificatieaspect namelijk een 6,4 . Dit is voor genoemde sector toch een verbetering ten opzichte van het vorig meetjaar. De beste score $(7,3)$ van alle BOL sectoren is ook een niveau 3 sector en wel de gezondheidszorgopleidingen. De duale opleidingen in het $\mathrm{MBO}$ doen het in het algemeen beter dan de $\mathrm{BOL}$ varianten. Het gemiddelde cijfer in de $\mathrm{BBL}$ is zoals gezegd een 7,2 tegenover een 6,9 voor het $\mathrm{BOL}$ als geheel. Het overgrote deel van de BBL sectoren heeft zelfs als eindoordeel een 7 of meer.

Ook in het $\mathrm{HBO}$ zijn de resultaten met betrekking tot het kwalificatieaspect goed te noemen. Zo hebben maar twee van de zeven sectoren een score onder de 7, landbouw een 6,9 en taal en cultuur een 6,8. Daarnaast is dit voor alle HBO sectoren behalve de landbouwsector een score die beter is dan het afgelopen meetjaar. Het WO scoort met een gemiddelde van 7,2 het beste van alle onderwijssoorten op het kwalificatie onderdeel. Tussen de onderliggende WO sectoren zijn er wel nog behoorlijk wat verschillen. Zo scoort de sector taal en cultuur slechts

17. Bijlage 2 geeft uitleg over de precieze berekening van de individuele totaalscores. 
een 6,2, terwijl de technici en de respondenten van gezondheidszorgopleidingen een goede beoordeling op dit onderdeel geven $(7,7)$. Evenals voor het HBO geldt voor het WO dat de cijfers gemiddeld iets beter zijn dan die van het afgelopen meetjaar.

\section{De selectiefunctie}

Zoals al uit hoofdstuk 3 bleek betreft de selectiefunctie het beoordelen van studenten op de aanwezige competenties en het op grond hiervan certificeren naar eindniveau. De totaalscore voor de selectiefunctie is gebaseerd op de individuele indicatoren (I) Strenge beoordeling van studenten, (2) Opleiding heeft uitdagend niveau, (3) Examens/opdrachten in het algemeen pittig en (4) Voldoende toetsen op inzicht. Voor elk van deze indicatoren is een score tussen de I en ro vastgesteld en het gemiddelde van deze scores wordt in tabel 6.I vermeld als eindbeoordeling "selectie".

Evenals verleden jaar zijn de scores met betrekking tot de selectiefunctie in het algemeen laag te noemen. De HBO afgestudeerden zijn het minst tevreden en scoren gemiddeld een 5,4. Het meest tevreden, maar slechts met een licht hogere score, zijn de gediplomeerden van het WO, zij waarderen hun opleiding gemiddeld met een 6,I.

Binnen het VMBO zijn ook bij de selectiefunctie de schoolverlaters van de theoretische leerweg met een cijfer van 5,6 het minst positief in hun beoordeling. De VMBO sector economie doet het met een 6 nog relatief goed ten opzichte van de andere VMBO sectoren. De BOL niveau 4 sector gedrag en maatschappij scoort het laagst $(5,2)$ van alle BOL sectoren. De BOL niveau I opleidingen halen binnen hun onderwijssoort de hoogste score namelijk een 6,2. Zowel binnen de BOL als de BBL halen de niveau I en 2 opleidingen gemiddeld een iets beter resultaat dan de niveau 3 en 4 opleidingen. Daarnaast is de gemiddelde score $(5,9)$ van de BBL op dit onderdeel iets beter dan het gemiddelde van 5,7 van de BOL. De verschillen tussen de onderliggende BBL sectoren zijn iets kleiner dan tussen de BOL sectoren onderling. Maar ook in de BOL zijn er geen echte uitschieters in positieve of negatieve zin.

Binnen het $\mathrm{HBO}$ is er geen enkele sector die een hogere score behaalt dan een 5,7 (gezondheidszorg). De HBO onderwijssector heeft zelfs het laagste cijfer $(5, \mathrm{I})$ van het gehele onderwijsveld. De cijfers lijken te suggereren dat men in het HBO de meeste moeite heeft met het goed beoordelen en selecteren van studenten op basis van hun competenties. De beoordeling van de WO sectoren is nog relatief het beste. Met name de sector taal en cultuur en de sector natuurwetenschappen krijgen op dit onderdeel een hoge waardering (beide een 6,4).

\section{De allocatiefunctie}

De allocatiefunctie van het onderwijs betreft de vraag of het onderwijs de schoolverlaters op een adequate wijze naar een vervolgopleiding of de arbeidsmarkt leidt. De totaalscore (I tot Io) voor de allocatiefunctie vervolgonderwijs is gebaseerd op (I) het percentage dat een vervolgopleiding in een verwante richting koos en (2) de tevredenheid met de aansluiting tussen gevolgde opleiding en vervolgopleiding. Het cijfer voor de allocatiefunctie arbeidsmarkt is gebaseerd op (I) de vraag of het functieniveau bij de opleiding past, (2) of de aansluiting tussen gevolgde opleiding en werk voldoende of goed is, (3) de benutting van de capaciteiten in de huidige functie en (4) de tevredenheid met de huidige functie. Tabel 6.I toont 
wat de resultaten zijn voor zowel de doorstroom naar de arbeidsmarkt als de doorstroom naar het vervolgonderwijs.

Wanneer naar de gemiddeldes per onderwijssoort gekeken wordt blijkt dat het WO het laagste cijfer heeft wat betreft de 'allocatiefunctie arbeidsmarkt'. Binnen zowel de BOL als de BBL zijn het de sector gedrag en maatschappij (niveau 3 en 4) en de niveau 4 opleidingen van de sector gezondheidszorg die de beste waardering voor deze indicator krijgen. Met name in de BBL zijn de scores goed te noemen. Van het gehele $\mathrm{MBO}$ is de enige onvoldoende voor de BOL niveau 2 sector landbouw (score 5,5 ).

Binnen het HBO komen de gediplomeerde leraren uit op de hoogste waardering voor hun opleidingen namelijk een 7,9 . De HBO landbouw sector en de sector gedrag en maatschappij doen het minder goed wat betreft de arbeidsmarktgerichte allocatiefunctie. Evenals in het MBO doet de sector gezondheidszorg het ook goed op WO niveau. Op dit niveau hebben deze opleidingen duidelijk de hoogste score namelijk een 7,8. Zeker in vergelijking met de taal en cultuur sector waar men niet verder komt dan een 5,5. Kortom, het lijkt erop dat met name de meer beroepsgerichte opleidingen voor deze indicator de hoogste waarderingen krijgen.

Zoals uit tabel 6.I blijkt zijn de scores voor de allocatiefunctie met betrekking tot de doorstroom naar het vervolgonderwijs slechts voor een aantal onderwijssoorten beschikbaar. Dit omdat de aantallen te laag zijn, oftewel de doorstroom naar het vervolgonderwijs te gering (BBL), of omdat deze indicator minder relevant is en de benodigde vragen niet aan de desbetreffende gediplomeerden gesteld zijn ( $\mathrm{HBO}$ en WO). Van de wel beschikbare cijfers liggen de gemiddeldes van de drie onderwijssoorten, AVO, VMBO en BOL, niet ver uit elkaar. De VMBO heeft het hoogste cijfer, een 7,6, de andere twee onderwijssoorten een 7,2. Binnen de VMBO doen met name de sectoren techniek en gezondheidszorg het goed, beide hebben een totaalscore van 8,o. De theoretische leerweg blijft met een 7,I een beetje achter bij de andere $\mathrm{VMBO}$ sectoren. Binnen de BOL krijgt de niveau 2 sector economie de hoogste totaalscore als het gaat om de allocatiefunctie met betrekking tot het vervolgonderwijs. Met een 8,4 doet de sector het beduidend beter dan de overige BOL sectoren. Het laagste cijfer, zowel binnen de BOL als voor alle onderwijssectoren, is voor de techniek opleidingen op niveau 4. De opleidingen uit deze sector komen gemiddeld niet verder dan een 6,4. 
Tabel 6.1

Totaalscores

$\begin{array}{cccc}\text { Kwalificatie } & \text { Selectie } & \begin{array}{r}\text { Allocatie: } \\ \text { arbeidsmarkt }\end{array} \\ \text { Totalscore } & \text { Totalscore } & \begin{array}{r}\text { Allocatie: } \\ \text { vervolgonderwijs }\end{array} & \begin{array}{r}\text { Externe rendement: } \\ \text { arbeidsmarkt }\end{array} \\ & \text { Totalscore } & \text { Totalscore } & \text { Totalscore }\end{array}$

\begin{tabular}{|c|c|c|c|c|c|}
\hline & \multicolumn{2}{|l|}{6,0} & \multicolumn{2}{|l|}{7,2} \\
\hline vwo & & 6,1 & & 7,2 & \\
\hline VMBO Theoretische leerweg & 6,1 & 5,6 & 7,1 & 7,1 & 5,4 \\
\hline VMBO landbouw & 6,4 & 5,9 & 7,5 & 7,6 & 5,7 \\
\hline VMBO techniek & 6,6 & 5,9 & 7,7 & 8,0 & 7,2 \\
\hline VMBO economie & 6,5 & 6,0 & 7,2 & 7,4 & 5,2 \\
\hline VMBO gezondheidszorg & 6,5 & 5,8 & 7,4 & 8,0 & 4,5 \\
\hline BOL niveau 1 & 6,8 & 6,2 & 6,6 & & 4,4 \\
\hline BOL niveau 2 landbouw & 6,7 & 5,5 & 5,5 & & 4,8 \\
\hline BOL niveau 2 techniek & 6,7 & 6,0 & 7,0 & 7,4 & 5,8 \\
\hline BOL niveau 2 economie & 6,7 & 5,8 & 6,5 & 8,4 & 4,8 \\
\hline BOL niveau 2 gezondheidszorg & 7,0 & 6,0 & 6,7 & & 4,7 \\
\hline BOL niveau 3 landbouw & 6,4 & 5,7 & 6,8 & & 5,9 \\
\hline BOL niveau 3 techniek & 6,9 & 5,6 & 7,3 & & 7,5 \\
\hline BOL niveau 3 economie & 6,7 & 5,7 & 7,0 & 7,1 & 6,0 \\
\hline BOL niveau 3 gezondheidszorg & 7,3 & 6,0 & 7,4 & 7,5 & 6,4 \\
\hline BOL niveau 3 gedrag en maatschappij & 7,0 & 5,7 & 7,8 & 7,5 & 6,6 \\
\hline BOL niveau 4 landbouw & 6,8 & 5,4 & 7,1 & & 4,9 \\
\hline BOL niveau 4 techniek & 7,0 & 5,5 & 7,3 & 6,4 & 6,6 \\
\hline BOL niveau 4 economie & 6,8 & 5,5 & 7,1 & 6,6 & 6,1 \\
\hline BOL niveau 4 gezondheidszorg & 7,1 & 5,7 & 8,2 & 7,3 & 7,7 \\
\hline BOL niveau 4 gedrag en maatschappij & 6,9 & 5,2 & 7,8 & 6,8 & 6,6 \\
\hline BBL 1 & 6,7 & 6,3 & 6,1 & & 4,8 \\
\hline BBL 2 landbouw & 6,9 & 5,9 & 6,6 & & 6,2 \\
\hline BBL 2 techniek & 7,3 & 6,1 & 6,9 & & 6,2 \\
\hline BBL 2 economie & 7,1 & 6,0 & 6,2 & & 5,7 \\
\hline BBL 2 gezondheidszorg & 7,1 & 6,0 & 7,4 & & 7,0 \\
\hline BBL 3 landbouw & 6,9 & 5,8 & 6,7 & & 6,3 \\
\hline BBL 3 techniek & 7,3 & 5,9 & 6,4 & & 7,7 \\
\hline BBL 3 economie & 7,1 & 5,7 & 6,9 & & 6,1 \\
\hline BBL 3 gezondheidszorg & 7,9 & 6,2 & 7,9 & & 7,7 \\
\hline BBL 3 gedrag en maatschappij & 7,3 & 6,2 & 8,0 & & 7,0 \\
\hline
\end{tabular}


Tabel 6.1

Totaalscores

\begin{tabular}{|c|c|c|c|c|}
\hline Kwalificatie & Selectie & $\begin{array}{r}\text { Allocatie: } \\
\text { arbeidsmarkt }\end{array}$ & $\begin{array}{r}\text { Allocatie: } \\
\text { vervolgonderwijs }\end{array}$ & $\begin{array}{r}\text { Externe rendement: } \\
\text { arbeidsmarkt }\end{array}$ \\
\hline Totaalscore & Totaalscore & Totaalscore & Totaalscore & Totaalscore \\
\hline
\end{tabular}

\begin{tabular}{|c|c|c|c|c|}
\hline BBL 4 techniek & 7,5 & 6,2 & 7,4 & 7,9 \\
\hline BBL 4 economie & 7,0 & 5,6 & 6,6 & 6,4 \\
\hline BBL 4 gezondheidszorg & 7,6 & 5,7 & 8,2 & 8,1 \\
\hline BBL 4 gedrag en maatschappij & 7,2 & 5,8 & 8,1 & 7,8 \\
\hline HBO landbouw & 6,9 & 5,6 & 6,7 & 6,5 \\
\hline $\mathrm{HBO}$ onderwijs & 7,1 & 5,1 & 7,9 & 6,2 \\
\hline HBO techniek & 7,2 & 5,5 & 7,5 & 8,3 \\
\hline HBO economie & 7,1 & 5,4 & 7,1 & 7,4 \\
\hline HBO gezondheidszorg & 7,1 & 5,7 & 7,5 & 7,4 \\
\hline HBO gedrag en maatschappij & 7,0 & 5,3 & 6,8 & 6,7 \\
\hline HBO taal en cultuur & 6,8 & & & 4,1 \\
\hline WO landbouw & 7,3 & 6,0 & 6,9 & 6,6 \\
\hline WO techniek & 7,7 & 6,2 & 7,1 & 8,1 \\
\hline W0 economie & 7,5 & 6,1 & 6,6 & 8,3 \\
\hline W0 gezondheidszorg & 7,7 & 5,7 & 7,8 & 8,0 \\
\hline W0 gedrag en maatschappij & 6,5 & 6,0 & 6,0 & 6,9 \\
\hline W0 taal en cultuur & 6,2 & 6,4 & 5,5 & 5,2 \\
\hline W0 recht en openbare orde & 7,2 & 6,2 & 7,2 & 7,6 \\
\hline W0 natuurwetenschappen & 7,5 & 6,4 & 6,9 & 7,3 \\
\hline
\end{tabular}

\section{Externe rendement}

Tot slot staan in tabel 6.I de totaalscores van het externe rendement met betrekking tot de arbeidsmarkt vermeld. De totaalscore is gebaseerd op drie onderdelen te weten: (I) de werkloosheid, (2) het bruto uurloon en (3) de carrièreperspectieven in de huidige functie. Om de looncijfers onderling vergelijkbaar te houden is voor het brutoloon rekening gehouden met de leeftijd en het aantal jaren gevolgde scholing.

Wanneer gekeken wordt naar het gemiddelde per onderwijssoort is er een duidelijk onderscheid tussen enerzijds $\operatorname{VMBO}(5,6)$ en $\mathrm{BOL}(5,9)$ en de andere onderwijssoorten die een 6,7 of hoger scoren op dit onderdeel. In het VMBO worden er behalve in de sector techniek $(7,2)$ alleen maar onvoldoendes gescoord op deze indicator. De sector gezondheidszorg heeft zelfs maar een 4,5. Ook bij de lage BOL niveaus (niveau I en 2) blijkt dat de studies eigenlijk niet geschikt zijn om een goede plek op de arbeidsmarkt te krijgen. Behalve op niveau 2 techniek 
$(5,8)$ scoren de BOL niveau I en 2 opleidingen allemaal een zware onvoldoende. De wat langere BOL opleidingen van niveau 3 en 4 hebben een aanzienlijk beter externe rendement op de arbeidsmarkt. De sector techniek niveau 3 heeft zelfs een totaalscore van 7,5 en de sector gezondheidszorg niveau 4 een 7,7 .

De BBL sectoren doen het in het algemeen iets beter dan de BOL varianten. Toch hebben ook hier de BBL niveau I opleidingen een bijzonder lage gemiddelde totaalscore voor dit onderdeel $(4,8)$. Alle BBL niveau 3 en 4 sectoren scoren een voldoende. De gemiddelde externe rendementscore van het $\mathrm{HBO}(6,7)$ ligt iets onder die van het WO $(7,2)$. Tussen de onderliggende $\mathrm{HBO}$ sectoren zijn er grote verschillen. Zo heeft de sector techniek een hele hoge totaalscore van 8,3 en de taal en cultuur sector nog niet de helft hiervan namelijk een 4,I. In het $\mathrm{WO}$ is het eveneens de taal en cultuur sector die een lage totaalscore krijgt $(5,2)$. Er zijn drie WO sectoren, techniek, economie en gezondheidszorg die een 8 of hoger scoren op dit onderdeel. 


\section{Regionale mobiliteit}

Ter afsluiting van dit rapport staan we stil bij de regionale mobiliteit van de scholieren en gediplomeerde schoolverlaters van het $\mathrm{MBO}$ en de studenten en afgestudeerden van het HBO. ${ }^{18}$ We doen dit aan de hand van de provincie waar de scholier/schoolverlater woonde en waar de schoolverlater werkt. Meer in detail, kijken we naar:

- Provincie waar men woonde toen men I5 jaar (MBO) of I6 jaar (HBO) oud was ('thuisprovincie');

- Provincie waar men woonde tijdens het laatste schooljaar (MBO) of studiejaar (HBO) ('studie-provincie');

- Provincie waar men woont op moment van enquête ('woon-provincie');

- Provincie waar men werkt op moment van enquête ('werk-provincie').

We beginnen bij de vraag of de 'studie-provincie' gelijk is aan de 'thuis-provincie' (initiële regionale mobiliteit). Tabel 7.2 laat zien dat slechts een klein percentage van de scholieren die een opleiding in het $\mathrm{MBO}$ kiezen, gedwongen of vrijwillig, van provincie verhuizen. Tussen de 6\% (MBO-BOL niveau I/2) en II\% (MBO-BBL niveau 3/4) van de respondenten woonde tijdens de $\mathrm{MBO}$-opleiding in een andere provincie dan voordat ze met de $\mathrm{MBO}$-opleiding zijn begonnen. Onder de studenten van het $\mathrm{HBO}$ is dit duidelijk hoger. In bijna een op de vier gevallen is de 'studie-provincie' anders dan de 'thuis-provincie'. Nader onderzoek laat zien dat de 'honkvastheid' onder de scholieren die voor een HBO-opleiding kiezen, ook verschilt tussen de regio's in Nederland. Van de 16 jarigen in de regio noord ${ }^{19}$ en oost volgde $67 \%$, respectievelijk $69 \%$ de $\mathrm{HBO}$-opleiding in de 'thuis-provincie'. In het zuiden en het westen van het land volgen scholieren iets vaker een HBO-opleiding in de 'thuis-provincie'. In het westen is het $82 \%$ en in het zuiden $8 \mathrm{I} \%$. Een vergelijkbaar beeld zien we bij de scholieren die voor het $\mathrm{MBO}$ kiezen. Ook hier kiezen scholieren in de regio zuid iets vaker dan gemiddeld voor een opleiding in de 'thuis-provincie'. De verschillen tussen de regio's zijn wel aanzienlijk kleiner onder de respondenten die voor een MBO-opleiding hebben gekozen. Zijn er dan nog verschillen tussen scholieren die voor een bepaalde opleidingsrichting in

I8. Voor de afgestudeerden van het WO zijn deze gegevens slechts gedeeltelijk beschikbaar. Zij worden daarom niet getoond. Verder worden buitenlandse studenten buiten de beschouwing gelaten. Hetzelfde geldt voor het klein percentage Nederlandse studenten die na het voltooien van de opleiding naar het buitenland verhuizen.

19. De regio noord omvat de provincies Groningen, Friesland en Drenthe. De regio oost omvat de provincies Overijssel en Gelderland, de regio west omvat de provincies Utrecht, Noord-Holland, Zuid-Holland en Zeeland, en de regio zuid omvat de provincies Noord-Brabant en Limburg. 
het $\mathrm{MBO}$ of het $\mathrm{HBO}$ hebben gekozen? Nader onderzoek laat zien dat er geen verschillen tussen de initiële regionale mobiliteit zijn als we de gekozen opleidingsrichting in het MBO (landbouw, techniek, economie, gezondheidszorg of gedrag en maatschappij) analyseren. In het $\mathrm{HBO}$ springt één sector eruit. $40 \%$ van de scholieren die voor een opleiding in de sector HBO landbouw kiest, verhuist ook daadwerkelijk naar de provincie waar deze opleiding aangeboden wordt. Deze regionale mobiliteit is daarbij niet echt verrassend. Immers, opleidingen in de sector landbouw worden slechts op een select aantal hogescholen aangeboden. Eenzelfde situatie zal zich waarschijnlijk voordoen bij scholieren die voor een opleiding in de kunstensector van het HBO kiezen. Door de afwijkende vragenlijst voor deze sector zijn hier echter geen gegevens beschikbaar.

Tabel 7.2

Woonplaats tijdens opleiding versus woonplaats toen men 15/16 jaar oud was

$\begin{array}{lrr} & \text { Zelfde provincie } & \text { Andere provincie } \\ \text { BOL } 1 / 2 & \% & \% \\ \text { BOL } 3 / 4 & 94 & 6 \\ \text { BBL } 1 / 2 & 93 & 7 \\ \text { BBL } 3 / 4 & 91 & 9 \\ \text { HBO } & 89 & 11 \\ \text { Bron: SIS } 2007 & 77 & 23\end{array}$

Nadat we vastgesteld hebben dat de 'initiële' regionale mobiliteit, de mobiliteit tussen de 'thuis-provincie' en de 'studie-provincie', relatief laag is, stelt zich de vraag of de regionale mobiliteit toeneemt na het behalen van het MBO- of het HBO-diploma. We concentreren ons daarbij op de respondenten die zich na het behalen van het diploma op de arbeidsmarkt aanbieden, en laten de gediplomeerde schoolverlaters die doorstromen naar een vervolgopleiding achterwege. Tabel 7.3 laat per opleidingsniveau het percentage zien dat:

- De opleiding in dezelfde provincie volgde als waar men woonde toen men $15 / 16$ jaar oud was en na het behalen van het diploma in dezelfde provincie blifft wonen: A $\rightarrow$ A $\rightarrow$ A.

- De opleiding in dezelfde provincie volgde als waar men woonde toen men $15 / 16$ jaar oud was en na het behalen van het diploma van provincie verhuisde: $\mathrm{A} \rightarrow \mathrm{A} \rightarrow \mathrm{B}$.

- De opleiding in een andere provincie volgde als waar men woonde toen men I5/16 jaar oud was maar na het behalen van het diploma terugkeerde naar de oude provincie: A -> B $\rightarrow$ A.

- De opleiding in een andere provincie volgde als waar men woonde toen men I5/16 jaar oud was en na het behalen van het diploma in de provincie van de studie bleef wonen: $\mathrm{A} \rightarrow \mathrm{B} \rightarrow \mathrm{B}$.

- De opleiding in een andere provincie volgde als waar men woonde toen men 15/16 jaar oud was en na het behalen van het diploma wederom van provincie wisselde: $\mathrm{A} \rightarrow \mathrm{B}$ $\rightarrow$ C. 
Tabel 7.3

$A \rightarrow A \rightarrow A \quad A-A \rightarrow B \quad A \rightarrow B-A \quad A \rightarrow B-B \quad B-C$

$\begin{array}{llllll}\text { BOL 1/2 } & 92 & 2 & 2 & 3 & 1 \\ \text { BOL 3/4 } & 87 & 6 & 2 & 4 & 1 \\ \text { BBL 1/2 } & 89 & 2 & 1 & 8 & 0 \\ \text { BBL 3/4 } & 85 & 4 & 1 & 9 & 1 \\ \text { HBO } & 71 & 6 & 7 & 11 & 5\end{array}$

Bron: SIS 2007

92\% van de gediplomeerde MBO-BOL niveau $\mathrm{I} / 2$ schoolverlaters is nooit van provincie veranderd. Zij volgden de MBO-opleiding in de thuis-provincie' en wonen op het moment van de enquête nog steeds in de 'thuis-provincie'. Onder de gediplomeerden van het MBOBOL niveau $3 / 4$ is men iets minder $(87 \%)$ loyaal aan de 'thuis-provincie'. Vergelijkbare cijfers vinden we voor de gediplomeerde schoolverlaters van het MBO-BBL. Voor de gediplomeerde schoolverlaters van de korte $\mathrm{MBO}-\mathrm{BBL}$ opleidingen geldt dat voor $89 \%$ de 'woon-provincie' gelijk is aan de 'studie-provincie' en gelijk is aan de 'thuis-provincie' Onder de gediplomeerde schoolverlaters van het MBO-BBL niveau 3/4 geldt dit voor $85 \%$. De consequentie van deze 'honkvastheid' onder de MBO schoolverlaters is dat slechts een klein percentage na het afronden van de opleiding de 'thuis-provincie' verlaat. $2 \%$ van de MBO-BOL en de MBO-BBL schoolverlaters van niveau $\mathrm{I} / 2$ die de opleiding in de 'thuis-provincie' volgde, verhuist daarna. Onder de schoolverlaters van het MBO-BBL niveau $3 / 4$ is het $4 \%$ en onder de schoolverlaters van het MBO-BOL niveau $3 / 4$ toch nog $6 \%$. Schoolverlaters van de langere MBO-opleidingen kennen hiermee een anzienlijke - maar nog steeds op een laag niveauregionale mobiliteit na het behalen van het diploma. Gedeeltelijk wordt deze 'braindrain' opgevangen door schoolverlaters die na het behalen van het diploma terugkeren naar de 'thuis-provincie' (A $\rightarrow$ B $\rightarrow$ A). Zo keert 33\% van de jongeren die een MBO-BOL niveau I/2 opleiding in een andere provincie gevolgd heeft terug naar de 'thuis-provincie'. Onder de jongeren van het MBO-BOL niveau $3 / 4$ is dit net iets minder dan $30 \%$. Onder de MBO-BBL schoolverlaters komt terugkeren naar de 'thuis-provincie' duidelijk minder voor. Zo blijft van alle MBO-BBL niveau $\mathrm{I} / 2$ schoolverlaters $8 \%$ in de 'studie-provincie' wonen. Onder de schoolverlaters van het MBO-BBL niveau $3 / 4$ is dit $9 \%$. Met andere woorden, zo'n $90 \%$ van de $\mathrm{MBO}-\mathrm{BBL}$ schoolverlaters die de opleiding niet in de 'thuis-provincie' volgen, keren niet terug naar de 'thuis-provincie'. Tot slot laat tabel 7.3 zien dat slechts een minimaal deel van de MBO-schoolverlaters 'echte globetrotters' zijn. Voor I\% van de MBO-BOL en de MBO$\mathrm{BBL}$ niveau $3 / 4$ schoolverlaters geldt dat ze ondertussen in een derde provincie wonen (A $\rightarrow$ $\mathrm{B}->\mathrm{C})$. Zijn er wat deze regionale mobiliteit betreft dan nog verschillen tussen de gekozen opleidingsrichting in het $\mathrm{MBO}$ of tussen de regio waarin de 'thuis-provincie' ligt. Nader onderzoek laat zien dat dit niet het geval is.

Hoewel we in tabel 7.2 hebben gezien dat de 'initiële' regionale mobiliteit onder de scholieren die voor een $\mathrm{HBO}$-opleiding kiezen duidelijk hoger is dan onder de scholieren die voor een MBO-opleiding kiezen, vinden we voor de $\mathrm{HBO}$-afgestudeerden in tabel 7.3 een vergelijkbaar patroon als voor de MBO-schoolverlaters. Zo blijft een duidelijke meerderheid (71\%) 
van de studenten/afgestudeerden zowel tijdens als na de studie in de 'thuis-provincie' wonen. $6 \%$ volgt de studie wel in de 'thuis-provincie' maar verhuist daarna. In tabel 7.2 hebben we al gezien dat zo'n $23 \%$ van de scholieren voor een HBO-studie in een andere dan de 'thuisprovincie' kiest. Tabel 7.3 laat nu zien hoe het met hun regionale mobiliteit na het behalen van het diploma staat. De $23 \%$ splitst zich op in $7 \%$ die na het behalen van het diploma terugkeren in de 'thuis-provincie', II\% die in de 'studie-provincie' blijven wonen en $5 \%$ die naar een 'derde' provincie verhuizen. Met andere woorden, zoals onder de schoolverlaters van het $\mathrm{MBO}$ zien we dat een groot deel van deze groep afgestudeerden in de 'studie-provincie' blijft wonen. Eerder hebben we aangegeven dat de "honkvastheid" van de jongeren die voor een $\mathrm{HBO}$-opleiding kiezen in het zuiden en het westen van het land hoger is. Nader onderzoek van de gegevens uit tabel 7.3 bevestigt dit resultaat nog een keer. Blijft in de regio's noord en oost 'slechts' $57 \%$, respectievelijk $61 \%$ tijdens en na de $\mathrm{HBO}$-studie in de 'thuis-provincie' wonen, is dit in het zuiden $75 \%$ en in het westen zelfs $77 \%$. Inclusief de jongeren die na het behalen van het HBO diploma weer terugkeren naar de 'thuis-provincie' woont daarmee $64 \%$ van de jongeren uit de regio noord en $69 \%$ van de jongeren uit de regio oost op moment van enquête in dezelfde provincie als met 16 jaar. In de regio zuid is het $81 \%$ en in de regio west zelfs $83 \%$.

Ten slotte kijken we nog naar eventuele (dagelijkse) mobiliteit tussen de 'woon-provincie' en de 'werk-provincie'. We doen dit apart voor drie groepen schoolverlaters: (I) de schoolverlaters die (weer) in de 'thuis-provincie' wonen, (2) de schoolverlaters die in de 'studie-provincie bleven wonen en (3) de schoolverlaters die in een derde provincie gingen wonen (zie Tabel $7 \cdot 4)$.

Tabel 7.4

$\%$ dat in dezelfde provincie werkt als ze wonen

$\begin{array}{lccc} & \text { 'thuis-provincie' } & \text { 'studie-provincie' } & \text { 'derde provincie' } \\ \text { BOL 1/2 } & 49 & 71 & 64 \\ \text { BOL 3/4 } & 68 & 83 & 58 \\ \text { BBL } 1 / 2 & 54 & 82 & 63 \\ \text { BBL 3/4 } & 72 & 87 & 56 \\ \text { HBO } & 68 & 77 & 57\end{array}$

Bron: SIS 2007

Zowel MBO schoolverlaters als $\mathrm{HBO}$ afgestudeerden die in de 'studie-provincie' blijven wonen, werken gemiddeld het vaakst ook in deze provincie. Tussen de $71 \%$ (MBO-BOL niveau $\mathrm{I} / 2$ ) en $87 \%$ (MBO-BBL niveau 3/4) werkt en woont in de 'studie-provincie'. Deels is dit zeker te verklaren doordat deze groep schoolverlaters wellicht door het snel vinden van werk in de 'studie-provincie' geen reden had om verder te verhuizen waardoor er sprake kan zijn van een relatief hoge selectiviteit. Interessant is dat dit ogenschijnlijk niet in geldt voor de schoolverlaters die na het behalen van het diploma in een 'derde' provincie gaan wonen. Van hen werkt tussen de 57\% (HBO) en 64\% (MBO-BOL niveau $\mathrm{r} / 2$ ) ook daadwerkelijk in deze provincie. Ten slotte zien we dat van de schoolverlaters die (weer) in de 'thuis-provincie' wonen tussen de $49 \%$ (MBO-BOL niveau I/2) en 72\% (MBO-BBL niveau 3/4) ook in de 'thuis-provincie' werkt. Overigens zijn er uiteraard ook veel schoolverlaters die vlakbij de 
provinciegrenzen wonen, waardoor het buiten de 'thuis-provincie' werken veel waarschijnlijker wordt.

Samenvattend kan vastgesteld worden dat zowel het $\mathrm{MBO}$ als ook het $\mathrm{HBO}$ een belangrijke leverancier van nieuwe arbeidskrachten voor met name de regionale arbeidsmarkt is. De grote meerderheid van de jongeren die een $\mathrm{MBO}$ of een $\mathrm{HBO}$ opleiding gaan volgen doen dit in de eigen provincie en blijven daarna ook in deze provincie wonen en werken. Slechts een klein percentage verhuist voor de opleiding. Wel blijft van hen een meerderheid daarna ook in de 'studie-provincie' wonen en werken. 


\section{Bijlage 1: Enkele centrale begrippen}

\section{Aansluitende functie naar niveau}

Een functie wordt als aansluitend naar niveau getypeerd indien het vereiste functieniveau ten minste gelijk is aan het genoten opleidingsniveau. Het functieniveau wordt bepaald aan de hand van de door de schoolverlaters beantwoorde vraag welk opleidingsniveau volgens de werkgever minimaal werd vereist.

\section{Aansluitende functie naar richting}

Een functie wordt als aansluitend naar richting getypeerd als de vereiste opleidingsrichting gelijk of verwant is aan de genoten opleidingsrichting. De vereiste opleidingsrichting wordt bepaald aan de hand van de door de schoolverlaters beantwoorde vraag welke opleidingsrichting volgens de werkgever werd vereist.

\section{Allocatiefunctie: Totaalscore arbeidsmarkt}

De totaalscore voor de allocatiefunctie arbeidsmarkt is gebaseerd op (I) de vraag of het functieniveau bij de opleiding past, (2) of de aansluiting tussen gevolgde opleiding en werk voldoende of goed is, (3) de benutting van de capaciteiten in de huidige functie en (4) de tevredenheid met de huidige functie.

\section{Allocatiefunctie: Totaalscore vervolgopleiding}

De totaalscore voor de allocatiefunctie vervolgonderwijs is gebaseerd op (I) het percentage dat een vervolgopleiding in een verwante richting koos en (2) de tevredenheid met de aansluiting tussen gevolgde opleiding en vervolgopleiding.

\section{Beroepsbevolking}

Tot de beroepsbevolking behoren:

- degenen die ten minste I2 uur per week werken of werk hebben aanvaard waardoor zij ten minste I2 uur per week gaan werken;

- degenen zonder werk (of met werk van minder dan I2 uur per week) die op zoek zijn naar werk.

In deze rapportage is tevens als voorwaarde gesteld dat de maatschappelijke positie niet scholier of student is. 


\section{Bruto uurloon}

Het bruto uurloon heeft betrekking op de hoofdfunctie, en is inclusief toeslagen maar exclusief inkomen uit overwerk. Het bruto uurloon is gelijk aan het bruto maandloon, gedeeld door het aantal arbeidsuren per week in de hoofdfunctie, vermenigvuldigd met de factor I2 $/ 52$.

\section{Externe rendement: Totaalscore arbeidsmarkt}

De totaalscore voor het externe rendement arbeidsmarkt is gebaseerd op de individuele indicatoren (I) werkloosheid, (2) bruto uurloon en (3) carrièreperspectieven in de huidige functie.

\section{Flexibele arbeidsrelatie}

Een flexibele arbeidsrelatie betreft een aanstelling als uitzendkracht, oproepkracht e.d. of een aanstelling in tijdelijke dienst.

\section{Kwalificatiefunctie: Totaalscore}

Het rapportcijfer voor de kwalificatiefunctie is gebaseerd op de individuele indicatoren (I) biedt de opleiding een goede basis om te starten op de arbeidsmarkt en (2) biedt de opleiding een goede basis om kennis en vaardigheden verder te ontwikkelen.

\section{Opleidingssector}

Binnen de onderwijssoorten is een onderverdeling gemaakt naar verschillende sectoren, bijvoorbeeld techniek, economie e.d.

\section{Onderwijssoort}

In het rapport worden de gediplomeerde schoolverlaters van de volgende onderwijssoorten onderscheiden:

AVO : algemeen voortgezet onderwijs, HAVO en VWO.

VMBO : voorbereidend middelbaar beroepsonderwijs.

BOL : beroepsopleidende leerweg van het secundair beroepsonderwijs.

Daarbinnen wordt een onderscheid gemaakt tussen niveau I (assistent

beroepsbeoefenaar $(\mathrm{AB})$ ) niveau 2 (beginnend beroepsbeoefenaar $(\mathrm{BB})$ ) niveau 3 (zelfstandig beroepsbeoefenaar (ZB)) en niveau 4 ((midden-)kaderfunctionaris (M)KF) of specialist).

$\mathrm{HBO}$ : hoger beroepsonderwijs.

WO : wetenschappelijk onderwijs. 


\section{Selectiefunctie: Totaalscore}

De totaalscore voor de selectiefunctie is gebaseerd op de individuele indicatoren (I) Strenge beoordeling van studenten, (2) Opleiding heeft uitdagend niveau, (3) Examens/opdrachten in het algemeen pittig en (4) Voldoende toetsen op inzicht.

\section{Werkloosheid}

In deze rapportage wordt uitgegaan van de definitie van werkloze beroepsbevolking: schoolverlaters zonder werk (of met werk van minder dan I2 uur per week) die op zoek zijn naar betaald werk. Daarbij is tevens als voorwaarde gesteld dat de maatschappelijke positie niet scholier of student is. 


\section{Bijlage 2: Kwaliteitsaspecten}

\section{A) Berekening scores en totaalscores}

Bij de berekening van de totaalscores hebben we de volgende uitgangspunten gehanteerd:

- Voor elk aspect - kwalificatie, selectie, allocatie en externe rendement - zijn meerdere indicatoren bepaald die gezamenlijk het begrip zo goed mogelijk afdekken.

- Voor indicatoren, gemeten op een 5-puntschaal, is de gemiddelde score met 2 vermenigvuldigd. Voor indicatoren, gemeten op een 4-puntschaal, is de gemiddelde score met 2,5 vermenigvuldigd.

- Voor de aansluiting opleiding-werk naar niveau, de aansluiting opleiding-vervolgopleiding naar richting en het bruto uurloon is een minimumwaarde bepaald. Waarden lager dan dit minimum geven aan dat de opleiding op dit aspect duidelijk onvoldoende scoort. Vervolgens is het percentage gediplomeerde schoolverlaters berekend dat op of boven het minimum zit. Dit percentage is vervolgens omgezet in een score. Hierbij hebben we als norm gehanteerd dat minimaal $75 \%$ op of boven het minimum moet zitten om een 6 te kunnen krijgen. De formule om het percentage om te zetten in een score is: Score $=10$ $-(($ IOO - Percentage $) * 4 / 25)$.

- De omzetting van het werkloosheidspercentage in een score is als volgt berekend: Score voor werkloosheid $=$ IO - Percentage ${ }^{*} 4 / 7,5$. Hierdoor scoort bijvoorbeeld $2 \%$ werkloosheid een 8,9; 5\% werkloosheid een 7,3 en I0\% werkloosheid een 4,7 .

- Om te voorkomen dat cijfers beneden de 6 zwaarder kunnen meewegen dan cijfers boven de 6, zijn alle cijfers lager dan 2 afgerond op 2,o.

- De uiteindelijke Totaalscore bedraagt het gemiddelde van de scores op de onderliggende indicatoren.

\section{B) Onderliggende Indicatoren}

\section{Kwalificatie:}

I) Starten op arbeidsmarkt:

In welke mate biedt uw opleiding een goede basis om te starten op de arbeidsmarkt? (I 'helemaal niet' $\mathrm{t} / \mathrm{m} 5$ 'in sterke mate').

2) Verder ontwikkelen van kennis en vaardigheden:

In welke mate biedt uw opleiding een goede basis voor het verder ontwikkelen van kennis en vaardigheden?

(I 'helemaal niet' $\mathrm{t} / \mathrm{m} 5$ 'in sterke mate'). 
Selectie:

I) Beoordeling leerlingen voldoende: streng:

Stelling: De docenten waren streng in de beoordeling van leerlingen

(I 'helemaal mee oneens' $\mathrm{t} / \mathrm{m} 5$ 'helemaal mee eens').

2) Opleiding heeft uitdagend niveau:

Stelling: De opleiding was uitdagend qua niveau

(I 'helemaal mee oneens' $\mathrm{t} / \mathrm{m} 5$ 'helemaal mee eens').

3) Examens/opdrachten voldoende pittig:

Stelling: De examens/opdrachten waren over het algemeen zeer pittig

(I 'helemaal mee oneens' t/m 5 'helemaal mee eens').

4) Voldoende toetsen op inzicht:

Stelling: In de opleiding werd voldoende getoetst op inzicht

(I 'helemaal mee oneens' $\mathrm{t} / \mathrm{m} 5$ 'helemaal mee eens').

Allocatie arbeidsmarkt:

I) Functieniveau past bij opleiding:

Wat is het opleidingsniveau dat vereist is door de werkgever?

2) Voldoende aansluiting opleiding-werk:

Hoe is de aansluiting tussen de gevolgde opleiding en de huidige functie? (I 'slecht' $\mathrm{t} / \mathrm{m} 4$ 'goed').

3) Voldoende benutting van kennis en vaardigheden:

In welke mate worden in uw huidige functie uw kennis en vaardigheden benut? (I 'helemaal niet' $t / m$ 's 'in sterke mate').

4) Tevreden met huidige functie:

Hoe tevreden bent $u$ met uw huidige functie?

(I 'zeer ontevreden' $\mathrm{t} / \mathrm{m} 5$ 'zeer tevreden'). 
Allocatie vervolgonderwijs:

I) Sector vervolgopleiding past bij opleidingssector:

Wat is de naam van deze (vervolg) opleiding?

2) Voldoende aansluiting met vervolgonderwijs:

Hoe is de aansluiting tussen de gevolgde opleiding en deze vervolgopleiding (I 'slecht' $\mathrm{t} / \mathrm{m} 4$ 'goed').

\section{Externe rendement arbeidsmarkt:}

I) Werkloosheid;

De werkloosheid is gemeten als het percentage oud-cursisten (behorend tot de beroepsbevolking) dat zoekt naar betaald werk en op dit moment minder dan I2 uur per week werkzaam is.

2) Bruto uurloon;

Het bruto uurloon is gelijk aan het bruto maandloon gedeeld door het aantal arbeidsuren per week, vermenigvuldigd met de factor $12 / 52$.

3) Voldoende carrièreperspectieven in huidige functie;

Biedt uw functie goede carrièremogelijkheden?

(I 'nauwelijks' t/m 5 'heel veel'). 
Bijlage 3: Kernindicatoren 1996-2007

Kernindicatoren 1996-2007

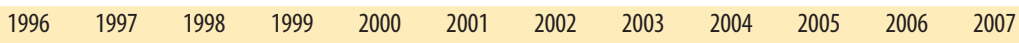

\begin{tabular}{llcccccccccccc}
\multicolumn{6}{l}{ Verder leren } & & & & & & & & \\
AV0 & $\%$ & 94 & 97 & 96 & 95 & 96 & 95 & 86 & 90 & 91 & 87 & 88 & 88 \\
VMB0 & $\%$ & 89 & 92 & 94 & 92 & 94 & 91 & 86 & 87 & 88 & 85 & 87 & 89 \\
BOL 1 & $\%$ & 48 & $*$ & $*$ & 44 & 51 & 51 & 36 & 53 & 38 & 34 & 45 & 23 \\
BOL2 & $\%$ & 48 & 42 & 50 & 51 & 46 & 52 & 45 & 52 & 49 & 36 & 63 & 32 \\
BOL 3 & $\%$ & 33 & 33 & 24 & 39 & 42 & 32 & 30 & 33 & 33 & 26 & 40 & 27 \\
BOL 4 & $\%$ & 43 & 45 & 46 & 49 & 50 & 49 & 51 & 52 & 56 & 55 & 56 & 55 \\
BBL 1 & $\%$ & - & - & - & - & - & - & - & - & - & - & - & 10 \\
BBL2 2 & $\%$ & - & - & - & - & - & - & - & - & - & - & - & 19 \\
BBL3 & $\%$ & - & - & - & - & - & - & - & - & - & - & - & 13 \\
BBL 4 & $\%$ & - & - & - & - & - & - & - & - & - & - & - & 15 \\
HB0 & $\%$ & 24 & 20 & 21 & 23 & 27 & 26 & 27 & 33 & 32 & 32 & 32 & 35 \\
W0 & $\%$ & 19 & 22 & 25 & 29 & 26 & 27 & 27 & 29 & 31 & 30 & 30 & 32
\end{tabular}

Werkloosheid

\begin{tabular}{|c|c|c|c|c|c|c|c|c|c|c|c|c|c|}
\hline AVO & $\%$ & 17 & 6 & 4 & 1 & * & 0 & 7 & 16 & 17 & 19 & 10 & 19 \\
\hline VMBO & $\%$ & 19 & 7 & 6 & 5 & 4 & 8 & 4 & 9 & 6 & 12 & 6 & 6 \\
\hline BOL 1 & $\%$ & 12 & * & * & 4 & 8 & 11 & 23 & 20 & 31 & 30 & 22 & 10 \\
\hline BOL 2 & $\%$ & 12 & 7 & 5 & 2 & 5 & 7 & 5 & 15 & 23 & 17 & 11 & 8 \\
\hline BOL 3 & $\%$ & 6 & 3 & 2 & 2 & 3 & 1 & 4 & 5 & 13 & 9 & 7 & 4 \\
\hline BOL 4 & $\%$ & 7 & 4 & 3 & 2 & 3 & 2 & 4 & 4 & 10 & 7 & 6 & 3 \\
\hline BBL 1 & $\%$ & - & - & - & - & - & - & - & - & - & - & - & 5 \\
\hline BBL 2 & $\%$ & - & - & - & - & - & - & - & - & - & - & - & 3 \\
\hline BBL 3 & $\%$ & - & - & - & - & - & - & - & - & - & - & - & 0 \\
\hline BBL 4 & $\%$ & - & - & - & - & - & - & - & - & - & - & - & 2 \\
\hline HBO & $\%$ & 7 & 5 & 4 & 3 & 4 & 3 & 4 & 6 & 6 & 5 & 5 & 3 \\
\hline WO & $\%$ & 5 & 3 & 3 & 3 & 3 & 3 & 3 & 5 & 5 & 4 & 4 & 3 \\
\hline
\end{tabular}

Flexibele aanstelling

\begin{tabular}{|c|c|c|c|c|c|c|c|c|c|c|c|c|}
\hline AVO & $\%$ & 37 & 33 & 32 & 28 & * & 25 & 47 & 40 & 37 & 53 & 63 \\
\hline VMBO & $\%$ & 24 & 26 & 22 & 18 & 11 & 19 & 27 & 32 & 44 & 54 & 48 \\
\hline BOL 1 & $\%$ & 41 & * & * & 21 & 17 & 23 & 46 & 25 & 48 & 47 & 74 \\
\hline BOL 2 & $\%$ & 34 & 32 & 26 & 22 & 22 & 21 & 26 & 35 & 47 & 46 & 51 \\
\hline BOL 3 & $\%$ & 28 & 24 & 20 & 20 & 16 & 12 & 20 & 28 & 38 & 43 & 49 \\
\hline BOL 4 & $\%$ & 26 & 24 & 19 & 18 & 16 & 14 & 22 & 31 & 40 & 43 & 42 \\
\hline
\end{tabular}


Bijlage 3: Kernindicatoren 1996-2006

Kernindicatoren 1996-2007

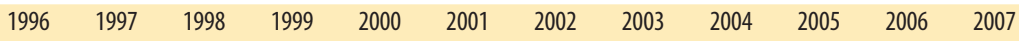

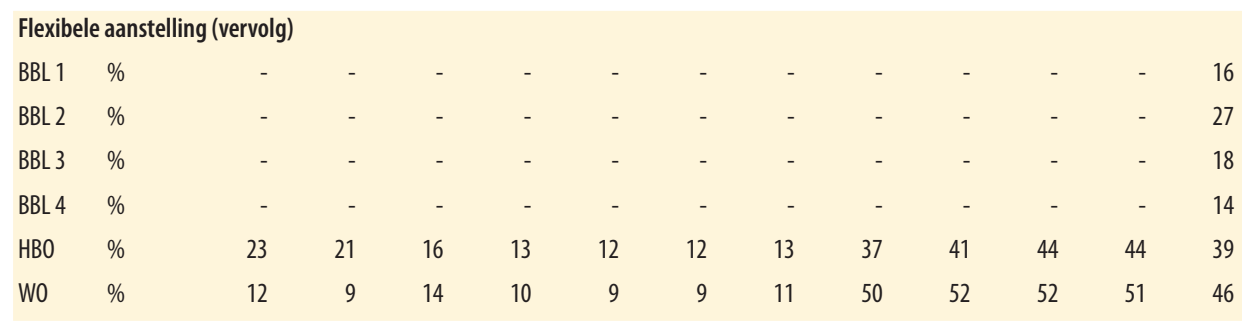

$\begin{array}{llrrrrrrrrrrrr}\text { Bruto uurloon } & & & & & & & & & & & & & \\ \text { AV0 } & € & 4.51 & 4.84 & 5.81 & 6.07 & * & 6.86 & 6.48 & 6.15 & 6.33 & 6.02 & 6.09 & 6.40 \\ \text { VMB0 } & € & 3.71 & 3.98 & 3.91 & 4.37 & 4.20 & 4.44 & 4.66 & 4.68 & 4.54 & 4.76 & 4.91 & 4.85 \\ \text { BOL 1 } & € & 4.69 & * & * & 5.54 & 5.86 & 6.51 & 7.06 & 5.64 & 6.41 & 6.69 & 5.55 & 7.85 \\ \text { BOL2 2 } & € & 5.19 & 5.11 & 5.87 & 6.10 & 6.15 & 7.20 & 6.74 & 6.54 & 6.88 & 6.94 & 6.86 & 7.60 \\ \text { BOL 3 } & € & 5.74 & 5.88 & 6.59 & 6.87 & 7.39 & 7.81 & 7.87 & 8.24 & 7.97 & 7.99 & 8.64 & 9.45 \\ \text { BOL 4 } & € & 6.37 & 6.60 & 7.42 & 7.90 & 8.15 & 8.91 & 8.44 & 8.52 & 8.68 & 8.75 & 9.45 & 10.10 \\ \text { BBL1 1 } & € & - & - & - & - & - & - & - & - & - & - & - & 9.00 \\ \text { BBL2 } & € & - & - & - & - & - & - & - & - & - & - & - & 9.80 \\ \text { BBL3 } & € & - & - & - & - & - & - & - & - & - & - & - & 11.40 \\ \text { BBL4 4 } & € & - & - & - & - & - & - & - & - & - & - & - & 12.65 \\ \text { HBO } & € & 8.78 & 9.30 & 10.19 & 10.89 & 11.37 & 11.59 & 11.90 & 12.05 & 11.70 & 11.74 & 12.68 & 13.10 \\ \text { W0 } & € & 10.39 & 10.99 & 11.88 & 12.00 & 13.24 & 13.29 & 13.83 & 14.06 & 14.14 & 14.39 & 14.76 & 15.60\end{array}$

\section{Minimaal eigen}

$\begin{array}{llrrrrrrrrrrrr}\text { AV0 } & \% & 52 & 54 & 64 & 60 & * & 94 & 57 & 54 & 58 & 49 & 66 & - \\ \text { VMB0 } & \% & 77 & 79 & 79 & 74 & 71 & 79 & 84 & 87 & 87 & 87 & 87 & 60 \\ \text { BOL 1 } & \% & 32 & * & * & 23 & 25 & 30 & 32 & 52 & 44 & 29 & 68 & 60 \\ \text { BOL2 } & \% & 55 & 51 & 53 & 61 & 56 & 49 & 64 & 68 & 63 & 61 & 63 & 64 \\ \text { BOL3 } & \% & 64 & 59 & 69 & 62 & 73 & 64 & 65 & 75 & 65 & 64 & 77 & 79 \\ \text { BOL 4 } & \% & 70 & 73 & 75 & 76 & 80 & 73 & 71 & 70 & 76 & 79 & 83 & 84 \\ \text { BBL 1 } & \% & - & - & - & - & - & - & - & - & - & - & - & 46 \\ \text { BBL2 2 } & \% & - & - & - & - & - & - & - & - & - & - & - & 64 \\ \text { BBL3 } & \% & - & - & - & - & - & - & - & - & - & - & - & 68 \\ \text { BBL4 } & \% & - & - & - & - & - & - & - & - & - & - & - & 87 \\ \text { HB0 } & \% & 77 & 80 & 80 & 81 & 80 & 79 & 77 & 76 & 75 & 77 & 82 & 85 \\ \text { W0 } & \% & 56 & 58 & 62 & 63 & 66 & 66 & 66 & 64 & 63 & 61 & 65 & 64\end{array}$

\begin{tabular}{|c|c|c|c|c|c|c|c|c|c|c|c|c|c|}
\hline \multicolumn{14}{|c|}{ Eigen/verwante richting } \\
\hline AVO & $\%$ & - & - & - & - & - & - & - & - & - & - & - & - \\
\hline VMBO & $\%$ & - & - & - & - & - & 53 & 62 & 62 & 64 & 58 & 62 & 48 \\
\hline BOL 1 & $\%$ & - & - & - & - & - & 37 & 46 & 38 & 56 & 49 & 51 & 37 \\
\hline BOL 2 & $\%$ & - & - & - & - & - & 57 & 62 & 58 & 64 & 53 & 57 & 50 \\
\hline BOL 3 & $\%$ & - & - & - & - & - & 76 & 71 & 78 & 70 & 67 & 74 & 73 \\
\hline
\end{tabular}


Kernindicatoren 1996-2007

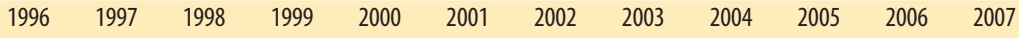

Eigen/verwante richting (vervolg)

\begin{tabular}{|c|c|c|c|c|c|c|c|c|c|c|c|c|}
\hline BOL 4 & $\%$ & - & - & - & - & - & 70 & 73 & 70 & 69 & 72 & 77 \\
\hline BBL 1 & $\%$ & - & 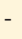 & - & - & - & - & - & - & - & - & - \\
\hline BBL 2 & $\%$ & - & - & - & - & - & - & - & - & - & - & - \\
\hline BBL 3 & $\%$ & - & - & - & - & - & - & - & - & - & - & - \\
\hline BBL 4 & $\%$ & - & 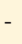 & - & - & - & - & - & - & - & - & - \\
\hline $\mathrm{HBO}$ & $\%$ & - & - & - & - & - & 76 & 78 & 79 & 78 & 76 & 80 \\
\hline Wo & $\%$ & - & - & 72 & 71 & 71 & 71 & 73 & 71 & 72 & 70 & 74 \\
\hline
\end{tabular}

\begin{tabular}{|c|c|c|c|c|c|c|c|c|c|c|c|c|c|}
\hline \multicolumn{14}{|c|}{ Zelfde opleiding opnieuw kiezen } \\
\hline AV0 & $\%$ & 75 & 80 & 79 & 82 & 83 & 81 & - & - & - & - & - & 96 \\
\hline VMBO & $\%$ & - & - & - & 79 & 79 & 80 & 76 & 86 & 84 & 85 & 88 & 84 \\
\hline BOL 1 & $\%$ & 52 & * & * & 65 & 55 & 69 & 68 & 55 & 60 & 63 & 66 & 61 \\
\hline BOL 2 & $\%$ & 59 & 59 & 62 & 66 & 72 & 63 & 64 & 73 & 62 & 60 & 67 & 64 \\
\hline BOL 3 & $\%$ & 69 & 60 & 66 & 72 & 74 & 77 & 72 & 79 & 76 & 71 & 74 & 75 \\
\hline BOL 4 & $\%$ & 75 & 74 & 75 & 80 & 81 & 79 & 78 & 82 & 77 & 78 & 77 & 80 \\
\hline BBL 1 & $\%$ & - & - & - & - & - & - & - & - & - & - & - & 61 \\
\hline BBL 2 & $\%$ & - & - & - & - & - & - & - & - & - & - & - & 74 \\
\hline BBL 3 & $\%$ & - & - & - & - & - & - & - & - & - & - & - & 81 \\
\hline BBL 4 & $\%$ & - & - & - & - & - & - & - & - & - & - & - & 80 \\
\hline HBO & $\%$ & 79 & 79 & 79 & 78 & 77 & 77 & 76 & 81 & 78 & 78 & 78 & 80 \\
\hline WO & $\%$ & 84 & 86 & 81 & 81 & 82 & 80 & 80 & 83 & 81 & 81 & 82 & 83 \\
\hline
\end{tabular}


Statistische Bijlage Tabellen naar opleidingssector 
Inhoud

Bladzijde

Voorwoord

Tabellen per opleidingssector

I Kernindicatoren

Ar.I Enkele kernindicatoren

2 Kenmerken van schoolverlaters

A2.I De uitstroom van schoolverlaters verbijzonderd naar geslacht, etniciteit en gemiddelde leeftijd op moment van enquête 85

$\begin{array}{lll}\text { A2.2 Vooropleiding van schoolverlaters } & 87\end{array}$

A2.3 Situatie op moment van enquête 88

3 Kwalficatie (hoe goed is men voorbereid op vervolgonderwijs of arbeidsmarkt?)

A3.I Oordeel van gediplomeerde schoolverlaters: breedte van gevolgde opleiding

A3.2 Oordeel van gediplomeerde schoolverlaters: diepgang van gevolgde opleiding

A3.3 Oordeel van gediplomeerde schoolverlaters: basis om kennis en vaardigheden verder te ontwikkelen

A3.4 Oordeel van gediplomeerde schoolverlaters: basis om te starten op arbeidsmarkt

4 Selectie (hoe streng is beoordeeld?)

A4.I Oordeel van gediplomeerde schoolverlaters: moeilijkheidsgraad van gevolgde opleiding

A4.2 Oordeel van gediplomeerde schoolverlaters: strenge beoordeling van studenten

A4.3 Oordeel van gediplomeerde schoolverlaters: uitdagend niveau IO2

A4.4 Oordeel van gediplomeerde schoolverlaters: pittige tentamens/opdrachten IO4

A4.5 Oordeel van gediplomeerde schoolverlaters: toetsen op inzicht I06

5 Doorstroom naar vervolgonderwijs: Allocatie (waar komt men terecht?)

A5.I Doorstroom van schoolverlaters naar vervolgonderwijs 
A5.2 Type vervolgonderwijs IIO

A5.3 Belangrijkste opleidingen van schoolverlaters die een vervolgopleiding zijn gaan volgen

A5.4 Doorstroom van schoolverlaters naar kenniscentrum beroepsonderwijs bedrijfsleven

A5.5 Oordeel van schoolverlaters over de aansluiting van de afgesloten opleiding met de vervolgopleiding

6 Doorstroom naar vervolgonderwijs: Rendement (wat levert het op?)

A6.I Uitvallers en studiewisselaars

7 Doorstroom naar vervolgonderwijs: Tevredenheid achteraf

A7.I Opleiding achteraf opnieuw kiezen: doorstroom naar vervolgonderwijs

8 Intrede op de arbeidsmarkt: Allocatie (waar komt men terecht?)

A8.I Belangrijkste bedrijfsgroepen waarin schoolverlaters werkzaam zijn

A8.2 Belangrijkste beroepsgroepen waarin schoolverlaters werkzaam zijn

A8.3 Grootte van de organisatie waarin schoolverlaters werkzaam zijn

A8.4 Vereist opleidingsniveau voor de huidige functie volgens de werkgever

A8.5 Vereiste opleidingsrichting voor de huidige functie volgens de werkgever

A8.6 Benutting van kennis en vaardigheden

A8.7 Kennis en vaardigheden schieten tekort

A8.8 Oordeel van de werkende schoolverlaters over de aansluiting tussen de afgesloten opleiding en de huidige functie

A8.9 Tevredenheid met huidige functie

9 Intrede op de arbeidsmarkt: Rendement (wat levert het op?)

A9.I Werkloosheid

A9.2 Werkloosheid tot eerste baan

A9.3 Percentage werkende schoolverlaters dat op zoek is naar een andere baan $\quad$ I53

A9.4 Aard van het dienstverband van werkende schoolverlaters $\quad$ I55

$\begin{array}{ll}\text { A9.5 Percentage werkende schoolverlaters met een flexibele aanstelling } & \text { I57 }\end{array}$

$\begin{array}{lll}\text { A9.6 Beloning van werkende schoolverlaters } & \text { I59 }\end{array}$

A9.7 Percentage werkende schoolverlaters met een deeltijdaanstelling en wekelijkse arbeidsduur

A9.8 Percentage werkende schoolverlaters waarvan huidige functie goede carrièremogelijkheden biedt

Io Intrede op de arbeidsmarkt: Tevredenheid achteraf

Aıo.I Opleiding achteraf opnieuw kiezen: intrede op de arbeidsmarkt

II Aantallen en respons

AIr.I Aantallen en respons 


\section{Voorwoord}

In deze Statistische Bijlage bij het rapport Schoolverlaters tussen onderwijs en arbeidsmarkt 2007 wordt een overzicht gegeven van de belangrijkste resultaten van de schoolverlatersonderzoeken die door het Researchcentrum voor Onderwijs en Arbeidsmarkt (ROA) in het najaar van 2007 zijn gehouden onder schoolverlaters en afgestudeerden van het school- of studiejaar 2005/2006. De gegevens bestrijken de volle breedte van het Nederlandse onderwijssysteem en hebben betrekking op de situatie van schoolverlaters en afgestudeerden ongeveer anderhalf jaar na het voltooien van de opleiding. Allereerst betreft het de VO-Monitor. Deze enquête is gericht op schoolverlaters van het algemeen voortgezet onderwijs (HAVO, VWO) en het voorbereidend beroepsonderwijs (VMBO). Vervolgens de BVE-Monitor, een enquête onder schoolverlaters van de beroepsopleidende (BOL) en beroepsbegeleidende leerweg (BBL) van het secundair beroepsonderwijs. Tot slot zijn gegevens opgenomen afkomstig uit de HBOMonitor en WO-Monitor. Dit zijn volledig vergelijkbare enquêtes gericht op afgestudeerden van het hoger onderwijs, die worden uitgevoerd onder toezicht van respectievelijk de HBOraad en de Vereniging van Samenwerkende Nederlandse Universiteiten (VSNU).

Voor alle getoonde gegevens geldt dat het gaat om gediplomeerde schoolverlaters en afgestudeerden. Bovendien betreft het alleen de uitstroom van voltijdopleidingen. In de statistische bijlage worden de belangrijkste gegevens per onderwijssoort en opleidingssector (bijvoorbeeld BOL niveau 2 techniek, HBO economie, WO gezondheidszorg) gepresenteerd. De tabellen uit deze statistische bijlage zijn voor de VO-Monitor en de BVE-Monitor ook op opleidingsniveau beschikbaar. Deze zijn te vinden op www.bvemonitor.nl en www.vomonitor.nl. Voor een gedetailleerd beeld van de resultaten voor het $\mathrm{HBO}$ wordt verwezen naar het Statistsch supplement van de HBO-Monitor 2007 (www.kengetallen.hbo.nl)

Er worden alleen voor die opleidingsrichtingen cijfers gepresenteerd waarvoor de resultaten voldoende betrouwbaar worden geacht. Daartoe is een ondergrens van 20 respondenten gehanteerd. Bij tabellen die betrekking hebben op de beroepsbevolking of op werkenden is de ondergrens gesteld op 20 respondenten die tot de beroepsbevolking behoren. Bij tabellen die betrekking hebben op vervolgopleidingen of cursussen is de ondergrens gelegd bij minimaal 20 respondenten die een vervolgopleiding respectievelijk cursus hebben gevolgd. Overigens kunnen de gepresenteerde percentages bij sommige tabellen - vanwege ontbrekende waarnemingen - op een geringer aantal respondenten zijn gebaseerd. Hiermee dient bij de interpretatie van de gegevens rekening te worden gehouden.

De opzet is als volgt: eerst worden enkele kernindicatoren gepresenteerd. Het tweede onderdeel biedt enkele achtergrondkenmerken van de schoolverlaters en geeft een beschrijving van de huidige situatie. De daaropvolgende twee onderdelen (Kwalificatie en Selectie) hebben betrekking op de gevolgde opleiding. Kwalificatie draait om de vraag of het onderwijs de schoolverlaters afdoende heeft toegerust met die competenties welke relevant zijn voor de doorstroming naar een vervolgopleiding of de arbeidsmarkt. Selectie betreft het beoordelen 
van studenten op de aanwezige competenties en het op grond hiervan certificeren naar eindniveau. Het vijfde tot zevende onderdeel gaat dieper in op de schoolverlaters die verder gaan leren. Eerst wordt gekeken waar men terecht is gekomen (Allocatie), daarna wordt dieper ingegaan op de vraag wat het opbrengt (Rendement) en tot slot wordt de Tevredenheid van deze groep schoolverlaters in kaart gebracht. De onderdelen acht tot en met tien gaan dieper in op de schoolverlaters die zich op de arbeidsmarkt aanbieden. Ook hier wordt eerst gekeken waar men terecht is gekomen (Allocatie), daarna wordt dieper ingegaan op de vraag wat het opbrengt (Rendement) en tot slot wordt de Tevredenheid van deze groep schoolverlaters in kaart gebracht. 
Tabel A1.1

Enkele kernindicatoren

\begin{tabular}{|c|c|c|c|c|c|c|c|c|c|}
\hline Opleidingssector & $\begin{array}{l}\text { benaderde } \\
\text { aantallen }\end{array}$ & $\begin{array}{l}\text { verder } \\
\text { leren }\end{array}$ & $\begin{array}{r}\text { zelfde } \\
\text { opleiding } \\
\text { opnieuw } \\
\text { kiezen }^{1)}\end{array}$ & $\begin{array}{r}\text { werk- } \\
\text { loosheid }\end{array}$ & $\begin{array}{r}\text { intrede } \\
\text { werk- } \\
\text { loosheid }\end{array}$ & $\begin{array}{r}\text { flexibele } \\
\text { aanstelling }\end{array}$ & $\begin{array}{r}\text { bruto } \\
\text { uurloon }\end{array}$ & $\begin{array}{r}\text { minimaal } \\
\text { eigen } \\
\text { niveau }\end{array}$ & $\begin{array}{r}\text { eigen/ } \\
\text { verwante } \\
\text { richting }\end{array}$ \\
\hline & & $\%$ & $\%$ & $\%$ & maanden & $\%$ & $€$ & $\%$ & $\%$ \\
\hline
\end{tabular}

\begin{tabular}{|c|c|c|c|c|c|c|c|c|}
\hline HAVO/VWO & 5.156 & 88 & 96 & 19 & $x$ & 65 & 6,42 & 60 \\
\hline HAVO & 2.909 & 88 & 95 & 17 & $x$ & 64 & 6,30 & 62 \\
\hline VWO & 2.247 & 88 & 98 & 23 & $x$ & 70 & 6,78 & 57 \\
\hline VMBO & 10.604 & 89 & 84 & 6 & 0,5 & 56 & 4,83 & 85 \\
\hline \multicolumn{9}{|l|}{ Naar leerweg } \\
\hline Theoretisch & 3.421 & 89 & 86 & 7 & 0,5 & 53 & 4,73 & 85 \\
\hline Gemengd & 793 & 94 & 86 & 2 & 0,6 & 61 & 4,90 & 83 \\
\hline Kaderberoepsgericht & 2.795 & 90 & 84 & 5 & 0,6 & 60 & 4,90 & 86 \\
\hline Basisberoepsgericht & 3.595 & 77 & 77 & 7 & 0,6 & 55 & 4,82 & 84 \\
\hline
\end{tabular}

\begin{tabular}{|c|c|c|c|c|c|c|c|c|c|}
\hline Naar sector & & & & & & & & & \\
\hline Landbouw & 2.047 & 89 & 81 & 5 & 0,3 & 54 & 4,66 & 84 & 60 \\
\hline Techniek & 1.855 & 80 & 75 & 3 & 0,3 & 56 & 5,21 & 86 & 58 \\
\hline Economie & 1.436 & 82 & 82 & 8 & 0,8 & 63 & 4,75 & 85 & 44 \\
\hline Gezondheidszorg & 1.845 & 84 & 86 & 10 & 0,9 & 55 & 4,42 & 85 & 43 \\
\hline BOL & 20.254 & 42 & 74 & 5 & 0,8 & 45 & 9,10 & 76 & 65 \\
\hline BoL niveau 1 & 1.283 & 23 & 61 & 10 & 1,9 & 72 & 7,84 & 60 & 37 \\
\hline BoL niveau 2 & 3.482 & 32 & 64 & 8 & 1,2 & 46 & 7,57 & 64 & 50 \\
\hline Landbouw & 143 & 26 & 72 & 13 & 0,5 & 55 & 6,08 & 50 & 33 \\
\hline Techniek & 885 & 31 & 64 & 4 & 1,3 & 43 & 7,64 & 72 & 59 \\
\hline Economie & 1.610 & 27 & 62 & 10 & 0,9 & 45 & 7,70 & 58 & 45 \\
\hline Gezondheidszorg & 841 & 41 & 65 & 10 & 1,9 & 51 & 7,40 & 65 & 52 \\
\hline BOL niveau 3 & 3.543 & 27 & 75 & 4 & 0,6 & 44 & 9,43 & 79 & 73 \\
\hline Landbouw & 244 & 16 & 68 & 1 & 0,5 & 32 & 7,86 & 65 & 60 \\
\hline Techniek & 321 & 20 & 75 & 0 & 0,2 & 40 & 10,92 & 75 & 83 \\
\hline Economie & 1.292 & 44 & 73 & 4 & 0,8 & 51 & 8,83 & 78 & 62 \\
\hline Gezondheidszorg & 723 & 16 & 76 & 4 & 0,2 & 41 & 9,41 & 78 & 76 \\
\hline Gedrag en maatschappij & 963 & 23 & 78 & 6 & 0,9 & 45 & 9,82 & 84 & 78 \\
\hline BOL niveau 4 & 11.946 & 55 & 80 & 3 & 0,4 & 40 & 10,06 & 84 & 76 \\
\hline Landbouw & 467 & 38 & 77 & 7 & 0,5 & 42 & 8,10 & 76 & 70 \\
\hline Techniek & 2.926 & 56 & 81 & 2 & 0,4 & 34 & 10,49 & 82 & 80 \\
\hline Economie & 4.505 & 59 & 75 & 3 & 0,6 & 44 & 9,22 & 79 & 62 \\
\hline Gezondheidszorg & 1.412 & 40 & 84 & 2 & 0,3 & 42 & 10,82 & 93 & 84 \\
\hline Gedrag en maatschappij & 2.636 & 61 & 84 & 4 & 0,4 & 39 & 10,46 & 91 & 84 \\
\hline BBL & 7.644 & 15 & 77 & 2 & 0,3 & 21 & 10,81 & 68 & 72 \\
\hline BBL niveau 1 & 598 & 10 & 61 & 5 & 0,7 & 16 & 9,00 & 46 & 52 \\
\hline BBL niveau 2 & 2.930 & 19 & 74 & 3 & 0,3 & 27 & 9,82 & 64 & 65 \\
\hline Landbouw & 248 & 18 & 69 & 0 & 0,1 & 13 & 9,73 & 67 & 59 \\
\hline Techniek & 1.382 & 27 & 76 & 2 & 0,2 & 25 & 9,48 & 65 & 71 \\
\hline Economie & 960 & 9 & 72 & 6 & 0,4 & 31 & 9,89 & 55 & 52 \\
\hline Gezondheidszorg & 340 & 15 & 76 & 2 & 0,3 & 27 & 10,73 & 75 & 71 \\
\hline
\end{tabular}


Tabel A1.1

Enkele kernindicatoren

\begin{tabular}{|c|c|c|c|c|c|c|c|c|c|}
\hline \multirow[t]{2}{*}{ Opleidingssector } & \multirow[t]{2}{*}{$\begin{array}{l}\text { benaderde } \\
\text { aantallen }\end{array}$} & \multirow[t]{2}{*}{$\begin{array}{r}\text { verder } \\
\text { leren }\end{array}$} & \multicolumn{2}{|l|}{$\begin{array}{r}\text { zelfde } \\
\text { opleiding } \\
\text { opnieuw } \\
\text { kiezen }{ }^{1)}\end{array}$} & \multirow[t]{2}{*}{$\begin{array}{r}\text { intrede } \\
\text { werk- } \\
\text { loosheid }\end{array}$} & \multirow[t]{2}{*}{$\begin{array}{r}\text { flexibele } \\
\text { aanstelling } \\
\%\end{array}$} & \multirow{2}{*}{$\begin{array}{r}\text { bruto } \\
\text { uurloon } \\
€\end{array}$} & \multirow{2}{*}{$\begin{array}{r}\text { minimaal } \\
\text { eigen } \\
\text { niveau } \\
\%\end{array}$} & \multirow{2}{*}{$\begin{array}{r}\text { eigen/ } \\
\text { verwante } \\
\text { richting } \\
\%\end{array}$} \\
\hline & & & $\%$ & $\%$ & & & & & \\
\hline BBL niveau 3 & 2.671 & 13 & 81 & 0 & 0,3 & 18 & 11,40 & 68 & 79 \\
\hline Landbouw & 164 & 5 & 83 & 0 & 0,2 & 18 & 11,26 & 59 & 69 \\
\hline Techniek & 1.034 & 20 & 83 & 0 & 0,2 & 18 & 11,62 & 52 & 75 \\
\hline Economie & 562 & 14 & 66 & 1 & 0,7 & 25 & 9,43 & 61 & 71 \\
\hline Gezondheidszorg & 692 & 7 & 84 & 0 & 0,0 & 13 & 12,00 & 83 & 87 \\
\hline Gedrag en maatschappij & 219 & 8 & 84 & 3 & 0,8 & 27 & 11,64 & 88 & 86 \\
\hline BBL niveau 4 & 1.445 & 15 & 80 & 2 & 0,1 & 14 & 12.63 & 87 & 84 \\
\hline Techniek & 332 & 19 & 86 & 6 & 0,0 & 12 & 13,32 & 82 & 90 \\
\hline Economie & 334 & 18 & 68 & 0 & 0,1 & 17 & 10,20 & 68 & 51 \\
\hline Gezondheidszorg & 398 & 16 & 82 & 0 & 0,1 & 13 & 13,03 & 93 & 94 \\
\hline Gedrag en maatschappij & 344 & 10 & 79 & 2 & 0,1 & 15 & 13,07 & 94 & 89 \\
\hline HBO & 37.085 & 35 & 80 & 3 & 0,9 & 39 & 13,06 & 85 & 82 \\
\hline Landbouw & 1.285 & 27 & 78 & 3 & 0,9 & 51 & 12,21 & 76 & 73 \\
\hline Onderwijs & 5.730 & 38 & 86 & 4 & 1,0 & 45 & 12,74 & 93 & 94 \\
\hline Techniek & 6.472 & 33 & 81 & 2 & 0.8 & 30 & 13,59 & 91 & 87 \\
\hline Economie & 13.777 & 42 & 74 & 4 & 0,9 & 38 & 13,19 & 84 & 69 \\
\hline Gezondheidszorg & 2.959 & 27 & 84 & 2 & 0,8 & 35 & 14,75 & 86 & 93 \\
\hline Gedrag en maatschappij & 4.143 & 29 & 79 & 4 & 1,1 & 45 & 12,73 & 73 & 85 \\
\hline Taal en cultuur & 2.719 & 24 & 84 & 7 & 1,1 & 48 & 10,14 & 81 & 100 \\
\hline W0 & 22.930 & 32 & 83 & 3 & 1,3 & 46 & 15,58 & 64 & 74 \\
\hline Landbouw & 961 & 30 & 82 & 6 & 1,6 & 56 & 13,93 & 70 & 83 \\
\hline Techniek & 2.572 & 19 & 85 & 2 & 1,3 & 36 & 15,51 & 72 & 80 \\
\hline Economie & 4.387 & 27 & 85 & 2 & 1,0 & 25 & 16,88 & 60 & 72 \\
\hline Gezondheidszorg & 2.774 & 49 & 87 & 3 & 1,0 & 62 & 16,82 & 85 & 87 \\
\hline Gedrag en maatschappij & 5.386 & 27 & 79 & 4 & 1,4 & 52 & 15,41 & 55 & 70 \\
\hline Taal en cultuur & 2.811 & 35 & 74 & 6 & 1,4 & 57 & 13,85 & 40 & 51 \\
\hline Recht en openbare orde & 2.438 & 40 & 85 & 3 & 1,2 & 50 & 15,68 & 79 & 78 \\
\hline Natuurwetenschappen & 1.601 & 40 & 83 & 4 & 1,1 & 49 & 14,39 & 67 & 81 \\
\hline Totaal & 103.673 & 58 & 83 & 4 & 0,7 & 40 & 10,69 & 75 & 69 \\
\hline
\end{tabular}

- = te weinig waarnemingen ; $\mathrm{x}=$ vraag niet opgenomen

1) voor het percentage voor verder lerenden zie tabel A7.1 en voor de werkenden zie tabel A10.1

Toelichting

Deze tabel geeft een samenvattend beeld. Zie ook de tabellen A11.1, A5.1, A9.1, A9.2, A9.5, A9.6, A8.4 en A8.5. 
Tabel A2.1

De uitstroom van schoolverlaters verbijzonderd naar geslacht, etniciteit en gemiddelde leeftijd op moment van enquête

\begin{tabular}{|c|c|c|c|c|c|}
\hline Opleidingssector & $\begin{array}{r}\text { vrouw } \\
\%\end{array}$ & $\begin{array}{r}\text { westerse allochtoon } \\
\%\end{array}$ & $\begin{array}{r}\text { niet-westerse allochtoon } \\
\%\end{array}$ & $\begin{array}{r}\text { autochtoon } \\
\%\end{array}$ & $\begin{array}{l}\text { leeftijd } \\
\text { gem. }\end{array}$ \\
\hline HAVO/VWO & 63 & 6 & 6 & 89 & 19,0 \\
\hline HAVO & 62 & 6 & 7 & 87 & 18,7 \\
\hline vW0 & 65 & 6 & 4 & 90 & 19,3 \\
\hline $\begin{array}{l}\text { VMBO } \\
\text { Naarleerweg }\end{array}$ & 58 & 5 & 12 & 83 & 17,6 \\
\hline Theoretisch & 62 & 4 & 10 & 87 & 17,6 \\
\hline Gemengd & 61 & 6 & 5 & 89 & 17,5 \\
\hline Kaderberoepsgericht & 58 & 6 & 13 & 81 & 17,6 \\
\hline Basisberoepsgericht & 51 & 7 & 17 & 76 & 17,8 \\
\hline
\end{tabular}

\begin{tabular}{|c|c|c|c|c|c|}
\hline \multicolumn{6}{|l|}{ Naar sector } \\
\hline Landbouw & 60 & 4 & 2 & 94 & 17,7 \\
\hline Techniek & 6 & 6 & 8 & 85 & 17,7 \\
\hline Economie & 57 & 7 & 27 & 66 & 17,8 \\
\hline Gezondheidszorg & 92 & 5 & 9 & 86 & 17,6 \\
\hline BOL & 60 & 6 & 16 & 79 & 22,7 \\
\hline BOL niveau 1 & 50 & 3 & 46 & 51 & 24,3 \\
\hline BOL niveau 2 & 54 & 8 & 19 & 73 & 22,0 \\
\hline Landbouw & 69 & 0 & 5 & 95 & 22,0 \\
\hline Techniek & 10 & 7 & 19 & 74 & 23,0 \\
\hline Economie & 52 & 10 & 18 & 72 & 21,3 \\
\hline Gezondheidszorg & 89 & 7 & 22 & 71 & 22,4 \\
\hline BOL niveau 3 & 72 & 5 & 13 & 82 & 23,0 \\
\hline Landbouw & 53 & 7 & 1 & 93 & 21,7 \\
\hline Techniek & 13 & 1 & 9 & 90 & 23,1 \\
\hline Economie & 52 & 6 & 19 & 75 & 22,0 \\
\hline Gezondheidszorg & 93 & 4 & 4 & 92 & 22,9 \\
\hline Gedrag en maatschappij & 95 & 6 & 17 & 77 & 24,1 \\
\hline BOL niveau 4 & 60 & 5 & 10 & 85 & 22,6 \\
\hline Landbouw & 55 & 6 & 1 & 93 & 21,9 \\
\hline Techniek & 24 & 4 & 6 & 90 & 22,5 \\
\hline Economie & 51 & 5 & 17 & 78 & 21,9 \\
\hline Gezondheidszorg & 88 & 3 & 6 & 91 & 23,0 \\
\hline Gedrag en maatschappij & 90 & 5 & 10 & 85 & 23,5 \\
\hline BBL & 47 & 5 & 9 & 86 & 30,6 \\
\hline BBL niveau 1 & 44 & 9 & 12 & 79 & 35,4 \\
\hline BBL niveau 2 & 37 & 5 & 11 & 84 & 29,4 \\
\hline Landbouw & 21 & 3 & 6 & 92 & 29,4 \\
\hline Techniek & 7 & 1 & 11 & 88 & 24,5 \\
\hline Economie & 52 & 11 & 11 & 78 & 31,1 \\
\hline Gezondheidszorg & 95 & 4 & 14 & 82 & 40,0 \\
\hline BBL niveau 3 & 52 & 5 & 7 & 88 & 30,0 \\
\hline Landbouw & 27 & 0 & 0 & 100 & 28,1 \\
\hline Techniek & 5 & 5 & 5 & 90 & 26,2 \\
\hline Economie & 47 & 4 & 4 & 91 & 26,2 \\
\hline Gezondheidszorg & 95 & 7 & 6 & 88 & 34,1 \\
\hline Gedrag en maatschappij & 94 & 7 & 24 & 69 & 37,0 \\
\hline
\end{tabular}


Tabel A2.1

De uitstroom van schoolverlaters verbijzonderd naar geslacht, etniciteit en gemiddelde leeftijd op moment van enquête

\begin{tabular}{|c|c|c|c|c|c|}
\hline Opleidingssector & $\begin{array}{r}\text { vrouw } \\
\%\end{array}$ & $\begin{array}{r}\text { westerse allochtoon } \\
\%\end{array}$ & $\begin{array}{r}\text { niet-westerse allochtoon } \\
\%\end{array}$ & $\begin{array}{r}\text { autochtoon } \\
\%\end{array}$ & $\begin{array}{l}\text { leeftijd } \\
\text { gem. }\end{array}$ \\
\hline BBL niveau 4 & 64 & 4 & 5 & 91 & 31,9 \\
\hline Techniek & 26 & 3 & 2 & 95 & 30,2 \\
\hline Economie & 59 & 5 & 4 & 91 & 26,2 \\
\hline Gezondheidszorg & 89 & 3 & 3 & 94 & 32,9 \\
\hline Gedrag en maatschappij & 72 & 5 & 12 & 83 & 37,2 \\
\hline HBO & 54 & 8 & 7 & 85 & 25,1 \\
\hline Landbouw & 45 & 3 & 3 & 95 & 24,6 \\
\hline Onderwijs & 81 & 3 & 4 & 93 & 25,2 \\
\hline Techniek & 12 & 6 & 7 & 87 & 25,0 \\
\hline Economie & 49 & 8 & 9 & 83 & 24,7 \\
\hline Gezondheidszorg & 81 & 7 & 3 & 90 & 25,9 \\
\hline Gedrag en maatschappij & 85 & 6 & 10 & 85 & 24,8 \\
\hline Taal en cultuur & 58 & 24 & 6 & 70 & 27,1 \\
\hline Wo & 54 & 9 & 5 & 86 & 27,3 \\
\hline Landbouw & 53 & 14 & 10 & 76 & 27,1 \\
\hline Techniek & 21 & 6 & 5 & 89 & 27,4 \\
\hline Economie & 28 & 11 & 7 & 82 & 26,8 \\
\hline Gezondheidszorg & 73 & 7 & 4 & 88 & 27,1 \\
\hline Gedrag en maatschappij & 73 & 9 & 4 & 88 & 27,4 \\
\hline Taal en cultuur & 72 & 11 & 2 & 87 & 28,3 \\
\hline Recht en openbare orde & 59 & 8 & 7 & 85 & 27,6 \\
\hline Natuurwetenschappen & 40 & 8 & 9 & 84 & 26,8 \\
\hline Totaal & 57 & 6 & 10 & 84 & 22,2 \\
\hline
\end{tabular}

Toelichting

Het betreft de leeftijd per onderzoeksdatum ongeveer anderhalf jaar na schoolverlaten.

Voor het WO zijn de resultaten met betrekking tot allochtonen gebaseerd op 12 universiteiten. 
Tabel A2.2

Vooropleiding van schoolverlaters

$\begin{array}{rrrrrrrrr}\text { Opleidingssector } & \text { MAVO } & \text { HAV0 } & \text { VW0 } & \text { VMBO } & \text { BOL } & \text { BBL } & \text { HBO } & \text { overig } \\ & \% & \% & \% & \% & \% & \% & \% & \%\end{array}$

HBO

Landbouw

Onderwijs

Techniek

Economie

Gezondheidszorg

Gedrag en maatschappij

Taal en cultuur

$\begin{array}{lll}46 & 19 & 0 \\ 45 & 13 & 0 \\ 52 & 14 & 0 \\ 40 & 17 & 0 \\ 50 & 21 & 0 \\ 45 & 25 & 0 \\ 49 & 13 & 0 \\ 26 & 33 & 0\end{array}$

$\begin{array}{rrrr}28 & 0 & 5 & 2 \\ 40 & 0 & 3 & 1 \\ 23 & 0 & 9 & 1 \\ 39 & 0 & 3 & 1 \\ 24 & 0 & 4 & 2 \\ 19 & 0 & 9 & 2 \\ 33 & 0 & 4 & 1 \\ 16 & 0 & 14 & 8\end{array}$

wo

$\begin{array}{lll}0 & 1 & 67 \\ 0 & 1 & 52 \\ 0 & 1 & 77 \\ 0 & 1 & 67 \\ 0 & 0 & 7 \\ 0 & 2 & 5 \\ 0 & 2 & 62 \\ 0 & 1 & 75 \\ 0 & 1 & 7\end{array}$

67
52
77
61
74
59
62
75
76

$\begin{array}{rrrrr}0 & 0 & 0 & 22 & 10 \\ 0 & 0 & 0 & 30 & 18 \\ 0 & 0 & 0 & 18 & 4 \\ 0 & 0 & 0 & 28 & 11 \\ 0 & 0 & 0 & 13 & 13 \\ 0 & 0 & 0 & 29 & 10 \\ 0 & 0 & 0 & 21 & 15 \\ 0 & 0 & 0 & 14 & 9 \\ 0 & 0 & 0 & 17 & 7 \\ 2 & 15 & 1 & 11 & 7\end{array}$

Totaal

5

25

33

Toelichting

Cijfers alleen beschikbaar voor HBO en WO. 
Tabel A2.3

Situatie op moment van enquête Opleidingssector studie

$\%$ combinatie

werk-leren

$\%$

HAVO

vwo

\section{VMBO}

Naar leerweg

Theoretisch

Gemengd

Kaderberoepsgericht

Basisberoepsgericht

Naar sector

Landbouw

Techniek

Economie

Gezondheidszorg

BOL

BOL niveau 1

BoL niveau 2

Landbouw

Techniek

Economie

Gezondheidszorg

BOL niveau 3

Landbouw

Techniek

Economie

Gezondheidszorg

Gedrag en maatschappij

BOL niveau 4

Landbouw

Techniek

Economie

Gezondheidszorg

Gedrag en maatschappij

BBL

BBL niveau 1

BBL niveau 2

Landbouw

Techniek

Economie

Gezondheidszorg

BBL niveau 3

Landbouw

Techniek

Economie

Gezondheidszorg

Gedrag en maatschappij

\section{2}

14

$\begin{array}{rrrr}81 & 12 & 3 & 3 \\ 78 & 14 & 4 & 3 \\ 85 & 9 & 2 & 4 \\ 61 & & 11 & 4 \\ 73 & 23 & 6 & 3 \\ 70 & & 6 & 3 \\ 59 & 17 & 11 & 5 \\ 40 & 21 & 22 & 5\end{array}$

$\begin{array}{lll}28 & 11 & 3 \\ 38 & 20 & 4 \\ 23 & 14 & 6 \\ 24 & 13 & 5\end{array}$

$\begin{array}{lll}14 & 48 & 7\end{array}$

$25 \quad 55$

11

20

20

27

19

30

16

$\begin{array}{rr}48 & 10 \\ 48 & 6 \\ 49 & 6 \\ 51 & 10 \\ 42 & 12\end{array}$

$\begin{array}{rll}12 & 66 & 6 \\ 11 & 73 & 6 \\ 11 & 72 & 0 \\ 14 & 51 & 5 \\ 13 & 70 & 7 \\ 9 & 74 & 7\end{array}$

$\begin{array}{rll}11 & 41 & 5 \\ 11 & 53 & 6 \\ 9 & 38 & 4 \\ 12 & 37 & 5 \\ 11 & 55 & 4 \\ 10 & 36 & 7\end{array}$

16

76

6

12

74

13

$\begin{array}{ll}74 & 6 \\ 81 & 6 \\ 70 & 4 \\ 78 & 4 \\ 73 & 9\end{array}$

$\begin{array}{rr}81 & 4 \\ 93 & 0 \\ 79 & 2 \\ 77 & 3 \\ 84 & 5 \\ 77 & 15\end{array}$


Tabel A2.3

Situatie op moment van enquête Opleidingssector

studie combinatie

werk-leren

$\%$

$\%$

BBL niveau 4

Techniek

Economie

Gezondheidszorg

Gedrag en maatschappij

HBO

Landbouw

Onderwijs

Techniek

Economie

Gezondheidszorg

Gedrag en maatschappij

Taal en cultuur

Wo

Landbouw

Techniek

Economie

Gezondheidszorg

Gedrag en maatschappij

Taal en cultuur

Recht en openbare orde

Natuurwetenschappen

Totaal

41

$\begin{array}{rr}3 & 17 \\ 0 & 16 \\ 10 & 11 \\ 2 & 24 \\ 2 & 15\end{array}$

16

11

24
15

17

11

14

10

$17-74$

5

79

79

68

77

betaald werk

anders

$\%$

5

1

77

6

74

76

77

76

82

77

70

9

8

9

$\mathrm{x}=$ vraag niet opgenomen 
Tabel A3.1

Oordeel van gediplomeerde schoolverlaters: breedte van gevolgde opleiding

Opleidingssector

te smal te breed

$\%$

\begin{tabular}{lrr} 
HAVO/VWO & 3 & 9 \\
HAVO & 3 & 7 \\
VWO & 2 & 12 \\
& & 6 \\
VMBO & 8 & 5 \\
Naar leerweg & 8 & 8 \\
Theoretisch & 9 & 6 \\
Gemengd & 7 & 8 \\
Kaderberoepsgericht & 7 & 6 \\
Basisberoepsgericht & 6 & 9 \\
\hline
\end{tabular}

Naar sector

Landbouw

Techniek

Economie

Gezondheidzorg

$\begin{array}{rr}4 & 12 \\ 8 & 7 \\ 8 & 7 \\ 7 & 6\end{array}$

BOL

BOL niveau 1

8 8

BOL niveau 2

Landbouw

Techniek

Economie

Gezondheidszorg

12

16

11

13

10

BOL niveau 3

Landbouw

Techniek

Economie

Gezondheidszorg

Gedrag en maatschappij

$\begin{array}{rl}9 & 7 \\ 15 & 4 \\ 6 & 4 \\ 10 & 7 \\ 7 & 9 \\ 9 & 7\end{array}$

B0L niveau 4

Landbouw

Techniek

Economie

Gezondheidszorg

Gedrag en maatschappij

$\begin{array}{rr}8 & 9 \\ 8 & 6 \\ 8 & 9 \\ 7 & 9 \\ 7 & 11 \\ 9 & 10\end{array}$

BBL

BBL niveau 1

BBL niveau 2

Landbouw

Techniek

Economie

Gezondheidszorg

$\begin{array}{rr}6 & 7 \\ 3 & 6 \\ 5 & 8 \\ 6 & 6 \\ 7 & 10\end{array}$

BBL niveau 3

Landbouw

Techniek

Economie

Gezondheidszorg

Gedrag en maatschappij

$\begin{array}{rr}4 & 8 \\ 8 & 3 \\ 4 & 6 \\ 6 & 10 \\ 3 & 10 \\ 5 & 7\end{array}$


Tabel A3.1

Oordeel van gediplomeerde schoolverlaters: breedte van gevolgde opleiding

Opleidingssector

te smal

te breed

BBL niveau 4

$7 \quad 12$

Techniek

Economie

Gezondheidszorg

Gedrag en maatschappij

12

4

8

9

HBO

Landbouw

Onderwijs

Techniek

Economie

Gezondheidszorg

Gedrag en maatschappij

W0

Landbouw

Techniek

Economie

Gezondheidszorg

Gedrag en maatschappij

Taal en cultuur

Recht en openbare orde

Natuurwetenschappen

Totaal

$\begin{array}{rr}5 & 19 \\ 3 & 22 \\ 14 & 8 \\ 4 & 16 \\ 2 & 26 \\ 6 & 13 \\ 4 & 23\end{array}$

3

210

10

$1-15$

11

$3-16$

610

Toelichting

Wat is uw oordeel over uw gevolgde opleiding met betrekking tot de breedte van de opleiding (1 'veel te smal' tot 7'veel te breed'). Vermeld is percentage van antwoordcategorie 1 en 2 (te smal) en antwoordcategorie 6 en 7 (te breed). 
Tabel A3.2

Oordeel van gediplomeerde schoolverlaters: diepgang van gevolgde opleiding

Opleidingssector

HAVO

VW0

VMBO

Naar leerweg

Theoretisch

Gemengd

Kaderberoepsgericht

Basisberoepsgericht

Naar sector

Landbouw

Techniek

Economie

Gezondheidszorg

BOL

BOL niveau 1

BOL niveau 2

Landbouw

22

Techniek

Economie

Gezondheidszorg

BOL niveau 3

Landbouw

Techniek

Economie

Gezondheidszorg

Gedrag en maatschappij

B0L niveau 4

Landbouw

Techniek

Economie

Gezondheidszorg

Gezondheidszorg

BBL

BBL niveau 1

BBL niveau 2

Landbouw

Techniek

Economie

Gezondheidszorg

BBL niveau 3

Landbouw

Techniek

Economie

Gezondheidszorg

Gedrag en maatschappij 
Tabel A3.2

Oordeel van gediplomeerde schoolverlaters: diepgang van gevolgde opleiding

Opleidingssector

BBL niveau 4

Techniek

Economie

Gezondheidszorg

Gedrag en maatschappij

HBO

Landbouw

Onderwijs

Techniek

Economie

Gezondheidszorg

Gedrag en maatschappij

Wo

Landbouw

Techniek

Economie

Gezondheidszorg

Gedrag en maatschappij

Taal en cultuur

Recht en openbare orde

Natuurwetenschappen

Totaal

Toelichting

Wat is uw oordeel over uw gevolgde opleiding met betrekking tot de diepgang van de opleiding (1 'te weinig' tot 7 'te veel'). Vermeld is percentage van antwoordcategorie 1 en 2 (te weinig). 
Tabel A3.3

Oordeel van gediplomeerde schoolverlaters: basis om kennis en vaardigheden verder te ontwikkelen

Opleidingssector

VMB0

Naar leerweg

Theoretisch

Gemengd

Kaderberoepsgericht

Basisberoepsgericht

Naar sector

Landbouw

Techniek

Economie

Gezondheidszorg

BOL niveau 1

BOL niveau 2

Landbouw

Techniek

Economie

Gezondheidszorg

BOL niveau 3

Landbouw

Techniek

Economie

Gezondheidszorg

Gedrag en maatschappij

BoL niveau 4

Landbouw

Techniek

Economie

Gezondheidszorg

Gedrag en maatschappij

BBL

BBL niveau 1

BBL niveau 2

Techniek

Economie

Gezondheidszorg

BBL niveau 3

BBL niveau 3

Landbouw

Techniek

Economie

Gezondheidszorg

Gedrag en maatschappij 
Tabel A3.3

Oordeel van gediplomeerde schoolverlaters: basis om kennis en vaardigheden verder te ontwikkelen

Opleidingssector

BBL niveau 4

Techniek

69

Economie

50

Gezondheidszorg

Gedrag en maatschappij

HBO

Landbouw

Onderwijs

Techniek

Economie

Gezondheidszorg

Gedrag en maatschappij

Taal en cultuur

WO

Landbouw

Techniek

Economie

Gezondheidszorg

Gedrag en maatschappij

Taal en cultuur

Recht en openbare orde

Natuurwetenschappen

Totaal

Toelichting

In welke mate biedt uw gevolgde opleiding een goede basis om kennis en vaardigheden verder te ontwikkelen ( 1 'helemaal niet' tot 5 'in sterkte mate'). Vermeld is het percentage van antwoordcategorie 4 en 5. 
Tabel A3.4

Oordeel van gediplomeerde schoolverlaters: basis om te starten op arbeidsmarkt

$\begin{array}{lr}\text { Opleidingssector } & \% \\ \text { VMBO } & 24 \\ \text { Naarleerweg } & 20 \\ \text { Theoretisch } & 22 \\ \text { Gemengd } & 27 \\ \text { Kaderberoepsgericht } & 30 \\ \text { Basisberoepsgericht } & 30\end{array}$

Naar sector

Landbouw

Techniek

Economie

Gezondheidszorg

BOL

BoL niveau 1

BOL niveau 2

Techniek

Economie

Gezondheidszorg

BOL niveau 3

Landbouw

Techniek

Economie

Gezondheidszorg

Gedrag en maatschappij

B0L niveau 4

Landbouw

Techniek

Economie

Gezondheidszorg

Gedrag en maatschappij

BBL

BBL niveau 1

BBL niveau 2

Techniek

Economie

Gezondheidszorg

BBL niveau 3

Techniek

Economie

Gezondheidszorg

Gedrag en mat

BBL niveau 4

Techniek

Economie

Gezondheidszorg

Gedrag en maatschappij 
Tabel A3.4

Oordeel van gediplomeerde schoolverlaters: basis om te starten op arbeidsmarkt

Opleidingssector

HBO

Landbouw

Onderwijs

Techniek

Economie

Gezondheidszorg

Gedrag en maatschappij

Taal en cultuur

Wo

Landbouw

Techniek

Economie

Gezondheidszorg

Gedrag en maatschappij

Taal en cultuur

Recht en openbare orde

Natuurwetenschappen

Totaal

Toelichting

Vraag in de enquête:

In welke mate biedt uw gevolgde opleiding een goede basis om te starten op de arbeidsmarkt ( 1 'helemaal niet' tot 5 'in sterke mate'). Vermeld is het percentage van antwoordcategorie 4 en 5. 
Tabel A4.1

Oordeel van gediplomeerde schoolverlaters: moeilijkheidsgraad van gevolgde opleiding

$\begin{array}{lrr}\text { Opleidingssector } & \text { te makkelijk } & \text { te moeilijk } \\ & \% & \\ \text { HAVO/VWO } & & 5 \\ \text { HAVO } & 11 & 5 \\ \text { VWO } & 9 & 5 \\ \text { VMBO } & 13 & 4 \\ \text { Naar leerweg } & 18 & 2 \\ \text { Theoretisch } & & 3 \\ \text { Gemengd } & 22 & 3 \\ \text { Kaderberoepsgericht } & 14 & 6 \\ \text { Basisberoepsgericht } & 16 & \\ \end{array}$

\begin{tabular}{|c|c|c|}
\hline \multicolumn{3}{|l|}{ Naar sector } \\
\hline Landbouw & 11 & 2 \\
\hline Techniek & 17 & 6 \\
\hline Economie & 16 & 5 \\
\hline Gezondheidszorg & 14 & 4 \\
\hline BOL & 22 & 5 \\
\hline BoL niveau 1 & 14 & 9 \\
\hline BOL niveau 2 & 20 & 8 \\
\hline Landbouw & 21 & 10 \\
\hline Techniek & 16 & 10 \\
\hline Economie & 24 & 5 \\
\hline Gezondheidszorg & 16 & 12 \\
\hline B0L niveau 3 & 19 & 4 \\
\hline Landbouw & 18 & 5 \\
\hline Techniek & 23 & 1 \\
\hline Economie & 19 & 5 \\
\hline Gezondheidszorg & 14 & 2 \\
\hline Gedrag en maatschappij & 21 & 3 \\
\hline BoL niveau 4 & 26 & 3 \\
\hline Landbouw & 23 & 1 \\
\hline Techniek & 24 & 4 \\
\hline Economie & 26 & 3 \\
\hline Gezondheidszorg & 19 & 3 \\
\hline Gedrag en maatschappij & 34 & 1 \\
\hline BBL & 15 & 5 \\
\hline BBL niveau 1 & 14 & 6 \\
\hline BBL niveau 2 & 14 & 7 \\
\hline Landbouw & 16 & 10 \\
\hline Techniek & 11 & 8 \\
\hline Economie & 16 & 3 \\
\hline Gezondheidszorg & 20 & 9 \\
\hline BBL niveau 3 & 12 & 4 \\
\hline Landbouw & 17 & 0 \\
\hline Techniek & 9 & 3 \\
\hline Economie & 16 & 4 \\
\hline Gezondheidszorg & 10 & 6 \\
\hline Gedrag en maatschappij & 20 & 5 \\
\hline
\end{tabular}


Tabel A4.1

Oordeel van gediplomeerde schoolverlaters: moeilijkheidsgraad van gevolgde opleiding

$\begin{array}{lrr}\text { Opleidingssector } & \text { te makkelijk } & \text { te moeilijk } \\ & \% & \% \\ & & 21 \\ \text { BBL niveau 4 } & 17 & 3 \\ \text { Techniek } & 21 & 1 \\ \text { Economie } & 18 & 2 \\ \text { Gezondheidszorg } & 31 & 0 \\ \text { Gedrag en maatschappij } & & 21 \\ \text { HBO } & 21 \\ \text { Landbouw } & 19 & 2 \\ \text { Onderwijs } & 28 & 1 \\ \text { Techniek } & 17 & 3 \\ \text { Economie } & 22 & 2 \\ \text { Gezondheidszorg } & 14 & 3 \\ \text { Gedrag en maatschappij } & 22 & 1\end{array}$

W0

Landbouw

Techniek

Economie

Gezondheidszorg

Gedrag en maatschappij

Taal en cultuur

Recht en openbare orde

Natuurwetenschappen

Totaal

17

Toelichting

Vraag in de enquête:

Wat is uw oordeel over uw gevolgde opleiding met betrekking tot de moeilijkheidsgraad van de opleiding ( 1 'veel te laag' tot 7 'veel te hoog'). Vermeld is het percentage van antwoordcategorie 1 en 2 (te makkelijk) en 6 en 7 (te moeilijk). 
Tabel A4.2

Oordeel van gediplomeerde schoolverlaters: strenge beoordeling van studenten

$\begin{array}{lr}\text { Opleidingssector } & \text { (helemaal) } \mathrm{m} \\ & \text { eens } \\ \text { HAV0/VwO } & \\ \text { HAVO } & 21 \\ \text { VWO } & 22 \\ \text { VMBO } & \\ \text { Naar leerweg } & \\ \text { Theoretisch } & 19 \\ \text { Gemengd } & \\ \text { Kaderberoepsgericht } & \\ \text { Basisberoepsgericht } & \end{array}$

$\begin{array}{rr}\text { mee } & \text { (helemaal) mee } \\ \text { oneens } \\ \% & \% \\ 21 & 35 \\ 21 & 35 \\ 22 & 36 \\ 19 & \\ & 37 \\ 19 & \\ 22 & 39 \\ 19 & 31 \\ 19 & 35 \\ \end{array}$

\begin{tabular}{|c|c|c|}
\hline \multicolumn{3}{|l|}{ Naar sector } \\
\hline Landbouw & 17 & 37 \\
\hline Techniek & 17 & 39 \\
\hline Economie & 26 & 32 \\
\hline Gezondheidszorg & 16 & 37 \\
\hline BOL & 17 & 44 \\
\hline BOL niveau 1 & 27 & 45 \\
\hline BOL niveau 2 & 21 & 38 \\
\hline Landbouw & 16 & 40 \\
\hline Techniek & 21 & 46 \\
\hline Economie & 22 & 35 \\
\hline Gezondheidszorg & 19 & 37 \\
\hline BOL niveau 3 & 17 & 43 \\
\hline Landbouw & 16 & 35 \\
\hline Techniek & 13 & 63 \\
\hline Economie & 20 & 42 \\
\hline Gezondheidszorg & 17 & 36 \\
\hline Gedrag en maatschappij & 14 & 44 \\
\hline BOL niveau 4 & 14 & 47 \\
\hline Landbouw & 12 & 50 \\
\hline Techniek & 15 & 45 \\
\hline Economie & 15 & 44 \\
\hline Gezondheidszorg & 15 & 45 \\
\hline Gedrag en maatschappij & 12 & 51 \\
\hline BBL & 16 & 44 \\
\hline BBL niveau 1 & 19 & 42 \\
\hline BBL niveau 2 & 18 & 42 \\
\hline Landbouw & 14 & 39 \\
\hline Techniek & 23 & 36 \\
\hline Economie & 14 & 46 \\
\hline Gezondheidszorg & 12 & 51 \\
\hline BBL niveau 3 & 15 & 44 \\
\hline Landbouw & 17 & 44 \\
\hline Techniek & 15 & 45 \\
\hline Economie & 9 & 59 \\
\hline Gezondheidszorg & 16 & 36 \\
\hline Gedrag en maatschappij & 19 & 46 \\
\hline
\end{tabular}


Tabel A4.2

Oordeel van gediplomeerde schoolverlaters: strenge beoordeling van studenten

\begin{tabular}{|c|c|c|}
\hline Opleidingssector & $\begin{array}{r}\text { (helemaal) mee } \\
\text { eens } \\
\%\end{array}$ & $\begin{array}{r}\text { (helemaal) mee } \\
\text { oneens } \\
\%\end{array}$ \\
\hline BBL niveau 4 & 14 & 49 \\
\hline Techniek & 14 & 57 \\
\hline Economie & 11 & 52 \\
\hline Gezondheidszorg & 16 & 45 \\
\hline Gedrag en maatschappij & 16 & 44 \\
\hline HBO & 15 & 46 \\
\hline Landbouw & 20 & 45 \\
\hline Onderwijs & 13 & 50 \\
\hline Techniek & 17 & 44 \\
\hline Economie & 15 & 46 \\
\hline Gezondheidszorg & 20 & 40 \\
\hline Gedrag en maatschappij & 11 & 50 \\
\hline wo & 22 & 40 \\
\hline Landbouw & 23 & 42 \\
\hline Techniek & 26 & 38 \\
\hline Economie & 26 & 36 \\
\hline Gezondheidszorg & 17 & 48 \\
\hline Gedrag en maatschappij & 19 & 44 \\
\hline Taal en cultuur & 24 & 39 \\
\hline Recht en openbare orde & 25 & 30 \\
\hline Natuurwetenschappen & 22 & 40 \\
\hline Totaal & 19 & 40 \\
\hline
\end{tabular}

Toelichting

Vraag in de enquête:

De docenten waren streng in de beoordeling van cursisten ( 1 'helemaal mee oneens' tot 5 'helemaal mee eens'). Vermeld is het percentage van antwoordcategorie 4 en 5 (helemaal mee eens) en 1 en 2 (helemaal mee oneens). 
Tabel A4.3

Oordeel van gediplomeerde schoolverlaters: uitdagend niveau

Opleidingssector
HAVO/VWO
HAVO
VWO
VMBO
Naarleerweg
Theoretisch
Gemengd
Kaderberoepsgericht
Basisberoepsgericht

$\begin{array}{rr}r & \text { (helemaal) mee oneens } \\ \% & \% \\ 33 & 35 \\ 31 & 36 \\ 35 & 34 \\ & \\ 24 & 40 \\ 20 & \\ 23 & 47 \\ 28 & 43 \\ 27 & 33\end{array}$

Naar sector
Landbouw
Techniek
Economie
Gezondheidszorg

BOL

$\begin{array}{ll}27 & 32 \\ 27 & 33 \\ 30 & 33 \\ 25 & 36\end{array}$

BoL niveau 1

BOL niveau 2

38

Techniek

Economie

Gezondheidszorg

BOL niveau 3

Landbouw

Techniek

Economie

Gezondheidszorg

Gedrag en maatschappij

36

41

42

BOL niveau 4

Landbouw

Techniek

Economie

Gezondheidszorg

Gedrag en maatschappij

BBL

BBL niveau 1

BBL niveau 2

Landbouw

Techniek

Economie

Gezondheidszorg

BBL niveau 3

Landbouw

Techniek

Economie

Gezondheidszorg

Gedrag en maatschappij 
Tabel A4.3

Oordeel van gediplomeerde schoolverlaters: uitdagend niveau

\begin{tabular}{|c|c|c|}
\hline Opleidingssector & $\begin{array}{r}\text { (helemaal) mee eens } \\
\%\end{array}$ & $\begin{array}{r}\text { (helemaal) mee oneens } \\
\%\end{array}$ \\
\hline BBL niveau 4 & 34 & 34 \\
\hline Techniek & 46 & 24 \\
\hline Economie & 27 & 45 \\
\hline Gezondheidszorg & 34 & 36 \\
\hline Gedrag en maatschappij & 30 & 33 \\
\hline HBO & 32 & 37 \\
\hline Landbouw & 31 & 34 \\
\hline Onderwijs & 23 & 47 \\
\hline Techniek & 37 & 32 \\
\hline Economie & 31 & 37 \\
\hline Gezondheidszorg & 46 & 28 \\
\hline Gedrag en maatschappij & 30 & 38 \\
\hline wo & 55 & 20 \\
\hline Landbouw & 59 & 18 \\
\hline Techniek & 66 & 14 \\
\hline Economie & 57 & 18 \\
\hline Gezondheidszorg & 51 & 23 \\
\hline Gedrag en maatschappij & 49 & 23 \\
\hline Taal en cultuur & 54 & 21 \\
\hline Recht en openbare orde & 47 & 19 \\
\hline Natuurwetenschappen & 66 & 13 \\
\hline Totaal & 32 & 35 \\
\hline
\end{tabular}

Toelichting

Vraag in de enquête:

De opleiding was uitdagend met betrekking tot niveau ( 1 'helemaal mee oneens' tot 5 'helemaal mee eens'). Vermeld is het percentage van antwoordcategorie 4 en 5 (helemaal mee eens) en 1 en 2 (helemaal mee oneens). 
Tabel A4.4

Oordeel van gediplomeerde schoolverlaters: pittige tentamens/opdrachten

\begin{tabular}{|c|c|c|}
\hline Opleidingssector & $\begin{array}{r}\text { (helemaal) mee eens } \\
\%\end{array}$ & $\begin{array}{r}\text { (helemaal) mee oneens } \\
\%\end{array}$ \\
\hline HAVO/VWO & 32 & 29 \\
\hline HAVO & 30 & 30 \\
\hline VW0 & 36 & 29 \\
\hline VMBO & 24 & 39 \\
\hline Naar leerweg & & \\
\hline Theoretisch & 24 & 42 \\
\hline Gemengd & 34 & 30 \\
\hline Kaderberoepsgericht & 23 & 37 \\
\hline Basisberoepsgericht & 23 & 41 \\
\hline Naar sector & & \\
\hline Landbouw & 23 & 39 \\
\hline Techniek & 22 & 40 \\
\hline Economie & 25 & 37 \\
\hline Gezondheidszorg & 26 & 36 \\
\hline BOL & 23 & 40 \\
\hline BoL niveau 1 & 35 & 34 \\
\hline BOL niveau 2 & 28 & 36 \\
\hline Landbouw & 9 & 34 \\
\hline Techniek & 32 & 30 \\
\hline Economie & 23 & 39 \\
\hline Gezondheidszorg & 33 & 35 \\
\hline BOL niveau 3 & 27 & 35 \\
\hline Landbouw & 25 & 29 \\
\hline Techniek & 23 & 43 \\
\hline Economie & 24 & 35 \\
\hline Gezondheidszorg & 36 & 30 \\
\hline Gedrag en maatschappij & 25 & 38 \\
\hline BOL niveau 4 & 18 & 46 \\
\hline Landbouw & 19 & 47 \\
\hline Techniek & 21 & 42 \\
\hline Economie & 18 & 45 \\
\hline Gezondheidszorg & 22 & 38 \\
\hline Gedrag en maatschappij & 14 & 55 \\
\hline BBL & 31 & 29 \\
\hline BBL niveau 1 & 24 & 30 \\
\hline BBL niveau 2 & 34 & 28 \\
\hline Landbouw & 25 & 28 \\
\hline Techniek & 37 & 23 \\
\hline Economie & 37 & 28 \\
\hline Gezondheidszorg & 27 & 39 \\
\hline BBL niveau 3 & 31 & 28 \\
\hline Landbouw & 29 & 37 \\
\hline Techniek & 30 & 28 \\
\hline Economie & 36 & 31 \\
\hline Gezondheidszorg & 33 & 26 \\
\hline Gedrag en maatschappij & 26 & 25 \\
\hline
\end{tabular}


Tabel A4.4

Oordeel van gediplomeerde schoolverlaters: pittige tentamens/opdrachten

\begin{tabular}{|c|c|c|}
\hline Opleidingssector & $\begin{array}{r}\text { (helemaal) mee eens } \\
\%\end{array}$ & $\begin{array}{r}\text { (helemaal) mee oneens } \\
\%\end{array}$ \\
\hline BBL niveau 4 & 27 & 32 \\
\hline Techniek & 32 & 21 \\
\hline Economie & 28 & 31 \\
\hline Gezondheidszorg & 28 & 39 \\
\hline Gedrag en maatschappij & 18 & 33 \\
\hline HBO & 20 & 41 \\
\hline Landbouw & 20 & 37 \\
\hline Onderwijs & 16 & 50 \\
\hline Techniek & 24 & 36 \\
\hline Economie & 20 & 41 \\
\hline Gezondheidszorg & 30 & 35 \\
\hline Gedrag en maatschappij & 15 & 47 \\
\hline wo & 30 & 32 \\
\hline Landbouw & 27 & 33 \\
\hline Techniek & 36 & 27 \\
\hline Economie & 37 & 26 \\
\hline Gezondheidszorg & 26 & 38 \\
\hline Gedrag en maatschappij & 23 & 37 \\
\hline Taal en cultuur & 30 & 33 \\
\hline Recht en openbare orde & 33 & 26 \\
\hline Natuurwetenschappen & 36 & 25 \\
\hline Totaal & 27 & 36 \\
\hline
\end{tabular}

Toelichting

Vraag in de enquête:

De examens/opdrachten waren over het algemeen zeer pittig ( 1 'helemaal mee oneens' tot 5 'helemaal mee eens'). Vermeld is het percentage van antwoordcategorie 4 en 5 (helemaal mee eens) en 1 en 2 (helemaal mee oneens). 
Tabel A4.5

Oordeel van gediplomeerde schoolverlaters: toetsen op inzicht

$\begin{array}{lcr}\text { Opleidingssector } & \text { (helemaal) mee eens } & \text { (helemaal) mee oneen } \\ & \% & 22 \\ \text { HAV0/VwO } & 45 & 24 \\ \text { HAVO } & 40 & 19 \\ \text { VWO } & 51 & 22 \\ \text { VMBO } & 40 & 25 \\ \text { Naar leerweg } & & 18 \\ \text { Theoretisch } & 38 & 19 \\ \text { Gemengd } & 38 & 19 \\ \text { Kaderberoepsgericht } & 42 & \\ \text { Basisberoepsgericht } & 43 & \end{array}$

Naar sector

Landbouw

Techniek

Economie

Gezondheidszorg

$\begin{array}{ll}45 & 20 \\ 43 & 17 \\ 43 & 18 \\ 40 & 21\end{array}$

BOL

BoL niveau 1

48

BOL niveau 2

Landbouw

Techniek

Economie

Gezondheidszorg

$\begin{array}{ll}36 & 27 \\ 25 & 28 \\ 38 & 27 \\ 34 & 28 \\ 38 & 27\end{array}$

BOL niveau 3

$36 \quad 29$

Landbouw

Techniek

Economie

Gezondheidszorg

Gedrag en maatschappij

2

BOL niveau 4

Landbouw

Techniek

Economie

Gezondheidszorg

Gedrag en maatschappij

$\begin{array}{ll}36 & 29 \\ 30 & 30 \\ 38 & 38 \\ 33 & 31 \\ 37 & 27 \\ 40 & 26\end{array}$

BBL

BBL niveau 1

$50 \quad 11$

BBL niveau 2

$43 \quad 21$

Landbouw

Techniek

Economie

Gezondheidszorg

$\begin{array}{ll}42 & 27 \\ 40 & 23\end{array}$

$\begin{array}{ll}40 & 23 \\ 46 & 21\end{array}$

$45 \quad 14$

BBL niveau 3

Landbouw

Techniek

Economie

Gezondheidszorg

Gedrag en maatschappij

$\begin{array}{ll}44 & 22 \\ 39 & 24 \\ 43 & 21 \\ 35 & 27 \\ 49 & 19 \\ 52 & 27\end{array}$


Tabel A4.5

Oordeel van gediplomeerde schoolverlaters: toetsen op inzicht

\begin{tabular}{|c|c|c|}
\hline Opleidingssector & $\begin{array}{r}\text { (helemaal) mee eens } \\
\%\end{array}$ & (helemaal) mee oneen \\
\hline BBL niveau 4 & 35 & 25 \\
\hline Techniek & 40 & 19 \\
\hline Economie & 32 & 25 \\
\hline Gezondheidszorg & 33 & 33 \\
\hline Gedrag en maatschappij & 34 & 19 \\
\hline $\mathrm{HBO}$ & 32 & 31 \\
\hline Landbouw & 35 & 26 \\
\hline Onderwijs & 27 & 36 \\
\hline Techniek & 34 & 30 \\
\hline Economie & 31 & 31 \\
\hline Gezondheidszorg & 37 & 31 \\
\hline Gedrag en maatschappij & 35 & 30 \\
\hline WO & 48 & 24 \\
\hline Landbouw & 50 & 19 \\
\hline Techniek & 51 & 24 \\
\hline Economie & 47 & 24 \\
\hline Gezondheidszorg & 37 & 34 \\
\hline Gedrag en maatschappij & 46 & 27 \\
\hline Taal en cultuur & 54 & 8 \\
\hline Recht en openbare orde & 44 & 22 \\
\hline Natuurwetenschappen & 63 & \\
\hline Totaal & 40 & \\
\hline
\end{tabular}

Toelichting

Vraag in de enquête:

In de opleiding werd voldoende getoetst op inzicht ( 1 helemaal mee oneens' tot 5 'helemaal mee eens'). Vermeld is het percentage van antwoordcategorie 4 en 5 (helemaal mee eens) en 1 en 2 (helemaal mee oneens). 
Tabel A5.1

Doorstroom van schoolverlaters naar vervolgonderwijs

$\begin{array}{lr}\text { Opleidingssector } & \text { verder leren } \\ & \% \\ \text { HAVO/NWO } & \mathbf{8 8} \\ \text { HAVO } & 88 \\ \text { VWO } & 88 \\ \text { VMBO } & \mathbf{8 9} \\ \text { Naarleerweg } & 93 \\ \text { Theoretisch } & 94 \\ \text { Gemengd } & 90 \\ \text { Kaderberoepsgericht } & 77 \\ \text { Basisberoepsgericht } & 77\end{array}$

Naar sector

Landbouw

Techniek

Economie

Gezondheidszorg

BOL

BOL niveau 1

BOL niveau 2

Techniek

Economie

31

Gezondheidszorg

BOL niveau 3

Techniek

Economie

Gezondheidszorg

Gedrag en maatschappij

BOL niveau 4

Landbouw

Techniek

Economie

Gezondheidszorg

Gedrag en maatschappij

BBL

BBL niveau 1

BBL niveau 2

Landbouw

Techniek

Economie

Gezondheidszorg

BBL niveau 3

Landbouw

Techniek

Economie

Gezondheidszorg

Gedrag en maatschappij 
Tabel A5.1

Doorstroom van schoolverlaters naar vervolgonderwijs

$\begin{array}{lr}\text { Opleidingssector } & \text { verderleren } \\ \%\end{array}$

$\begin{array}{ll}\text { BBL niveau } 4 & 15\end{array}$

$\begin{array}{lr}\text { Techniek } & 19\end{array}$

Economie $\quad 18$

Gezondheidszorg $\quad 16$

Gedrag en maatschappij $\quad 10$

HBO

\begin{tabular}{ll} 
Onderwijs & 27 \\
\hline 38 & 33
\end{tabular}

Techniek

\begin{tabular}{ll} 
Economie & 42 \\
\hline
\end{tabular}

$\begin{array}{ll}\text { Gezondheidszorg } & 27\end{array}$

$\begin{array}{lr}\text { Gedrag en maatschappij } & 29\end{array}$

$\begin{array}{ll}\text { Taal en cultuur } & 24\end{array}$

W0 32

\begin{tabular}{lr} 
Landbouw & 30 \\
\hline
\end{tabular}

$\begin{array}{lr}\text { Techniek } & 19\end{array}$

$\begin{array}{ll}\text { Economie } & 27\end{array}$

$\begin{array}{lr}\text { Gezondheidszorg } & 49\end{array}$

$\begin{array}{ll}\text { Gedrag en maatschappij } & 27\end{array}$

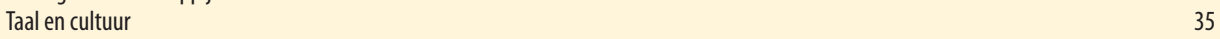

$\begin{array}{lr}\text { Recht en openbare orde } & 40\end{array}$

$\begin{array}{lr}\text { Natuurwetenschappen } & 40\end{array}$

$\begin{array}{ll}\text { Totaal } & 58\end{array}$

De cijfers met betrekking tot 'verder leren' wijken vooral bij de schoolverlaters van de opleidingen op MBO niveau 1, 2 en 3 nogal af van de cijfers zoals gepresenteerd in de publicatie 'Kerncijfers 2003-2007' van het Ministerie van Onderwijs. De reden hiervoor is dat de respons onder de schoolverlaters die binnen het MBO doorstromen naar een hoger opleidingsniveau duidelijk lager ligt dan de respons onder de schoolverlaters die zich op de arbeidsmarkt aanbieden. 
Tabel A5.2

Type vervolgonderwijs

\begin{tabular}{|c|c|c|c|c|c|c|c|c|c|c|c|}
\hline \multirow[t]{2}{*}{ 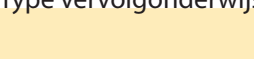 } & HAVO & vwo & VMBO & $\mathrm{BOL}$ & BOL & BBL & BBL & HBO & post & wo & post \\
\hline & & & & niv. $1 / 2$ & niv. $3 / 4$ & niv. $1 / 2$ & niv. $3 / 4$ & & HBO & & wo \\
\hline Opleidingssector & $\%$ & $\%$ & $\%$ & $\%$ & $\%$ & $\%$ & $\%$ & $\%$ & $\%$ & $\%$ & $\%$ \\
\hline HAVO/VWO & 0 & 1 & 0 & 0 & 2 & 0 & 0 & 53 & 0 & 30 & 0 \\
\hline HAVO & 0 & 1 & 0 & 0 & 4 & 0 & 1 & 80 & 0 & 1 & 0 \\
\hline VW0 & 0 & 0 & 0 & 0 & 0 & 0 & 0 & 19 & 0 & 68 & 0 \\
\hline VMBO & 4 & 0 & 0 & 14 & 56 & 8 & 5 & 0 & 0 & 0 & 0 \\
\hline Naar leerweg & & & & & & & & & & & \\
\hline Theoretisch & 10 & 0 & 0 & 4 & 71 & 2 & 5 & 0 & 0 & 0 & 0 \\
\hline Gemengd & 0 & 0 & 0 & 3 & 83 & 2 & 5 & 0 & 0 & 0 & 0 \\
\hline Kaderberoepsgericht & 0 & 0 & 0 & 10 & 65 & 8 & 6 & 0 & 0 & 0 & 0 \\
\hline Basisberoepsgericht & 0 & 0 & 0 & 40 & 11 & 19 & 5 & 0 & 0 & 0 & 0 \\
\hline
\end{tabular}

\begin{tabular}{|c|c|c|c|c|c|c|c|c|c|c|}
\hline Naar sector & & & & & & & & & & \\
\hline Landbouw & 0 & 0 & 0 & 26 & 45 & 11 & 11 & 0 & 0 & 0 \\
\hline Techniek & 0 & 0 & 0 & 17 & 33 & 28 & 4 & 0 & 0 & 0 \\
\hline Economie & 0 & 0 & 1 & 22 & 49 & 8 & 4 & 1 & 0 & 0 \\
\hline Gezondheidszorg & 0 & 0 & 0 & 23 & 52 & 4 & 6 & 0 & 0 & 0 \\
\hline
\end{tabular}

BOL

BoL niveau 1

$\begin{array}{lllllllllll}0 & 0 & 0 & 1 & 7 & 1 & 3 & 29 & 0 & 0 & 0\end{array}$

$\begin{array}{llllllllllll}\text { BOL niveau } 2 & 0 & 0 & 0 & 1 & 19 & 1 & 8 & 2 & 0 & 0 & 0\end{array}$

Techniek

Economie

Gezondheidszorg

\begin{tabular}{|c|c|c|c|c|c|c|c|c|c|c|c|}
\hline B0L niveau 3 & 0 & 0 & 0 & 0 & 7 & 0 & 2 & 16 & 0 & 0 & 0 \\
\hline Economie & 0 & 0 & 0 & 1 & 8 & 0 & 1 & 31 & 0 & 0 & 0 \\
\hline Gezondheidszorg & 0 & 0 & 0 & 0 & 6 & 0 & 3 & 5 & 0 & 0 & 0 \\
\hline Gedrag en maatschappij & 0 & 0 & 0 & 0 & 8 & 0 & 2 & 13 & 0 & 0 & 0 \\
\hline BOL niveau 4 & 0 & 0 & 0 & 0 & 2 & 0 & 1 & 52 & 0 & 0 & 0 \\
\hline Landbouw & 0 & 0 & 0 & 0 & 1 & 1 & 1 & 34 & 0 & 0 & 0 \\
\hline Techniek & 0 & 0 & 0 & 0 & 2 & 0 & 1 & 51 & 1 & 0 & 0 \\
\hline Economie & 0 & 0 & 0 & 0 & 1 & 0 & 0 & 57 & 0 & 0 & 0 \\
\hline Gezondheidszorg & 0 & 0 & 0 & 0 & 3 & 0 & 0 & 36 & 0 & 0 & 0 \\
\hline Gedrag en maatschappij & 0 & 0 & 0 & 0 & 2 & 0 & 1 & 58 & 0 & 0 & 0 \\
\hline BBL & 0 & 0 & 0 & 0 & 2 & 1 & 8 & 3 & 0 & 0 & 0 \\
\hline BBL niveau 2 & 0 & 0 & 0 & 1 & 2 & 2 & 13 & 1 & 0 & 0 & 0 \\
\hline BBL niveau 3 & 0 & 0 & 0 & 0 & 2 & 0 & 6 & 3 & 0 & 0 & 0 \\
\hline BBL niveau 4 & 0 & 0 & 0 & 0 & 1 & 0 & 3 & 11 & 0 & 0 & 0 \\
\hline HBO & 0 & 0 & 0 & 0 & 0 & 0 & 0 & 8 & 0 & 21 & 0 \\
\hline Landbouw & 0 & 0 & 0 & 0 & 0 & 0 & 0 & 6 & 0 & 18 & 0 \\
\hline Onderwijs & 0 & 0 & 0 & 0 & 0 & 0 & 0 & 18 & 0 & 11 & 0 \\
\hline Techniek & 0 & 0 & 0 & 0 & 0 & 0 & 0 & 4 & 0 & 24 & 0 \\
\hline Economie & 0 & 0 & 0 & 0 & 0 & 0 & 0 & 6 & 0 & 31 & 0 \\
\hline Gezondheidszorg & 0 & 0 & 0 & 0 & 0 & 0 & 0 & 8 & 0 & 12 & 0 \\
\hline Gedrag en maatschappij & 0 & 0 & 0 & 0 & 0 & 0 & 0 & 6 & 0 & 18 & 0 \\
\hline Taal en cultuur & 0 & 0 & 0 & 0 & 0 & 0 & 0 & 12 & 3 & 5 & 0 \\
\hline
\end{tabular}


Statistische Bijlage

Tabel A5.2

$\begin{array}{lrrrrrrrrrrr}\text { Type vervolgonderwijs } & & & & & & & & & \\ & \text { HAVO } & \text { VWO } & \text { VMBO } & \text { BOL } & \text { BOL } & \text { BBL } & \text { BBL } & \text { HBO } & \text { post } & \text { W0 } & \text { post } \\ \text { Opleidingssector } & \% & \% & \% & \% & \% & \% & \% & \% & \% & \% & \%\end{array}$

W0

Landbouw

Techniek

Economie

Gezondheidszorg

Gedrag en maatschappij

Taal en cultuur

Recht en openbare orde

Natuurwetenschappen

$\begin{array}{rrrrrrrrrrr}0 & 0 & 0 & 0 & 0 & 0 & 0 & 2 & 0 & 9 & 14 \\ 0 & 0 & 0 & 0 & 0 & 0 & 0 & 0 & 0 & 5 & 21 \\ 0 & 0 & 0 & 0 & 0 & 0 & 0 & 1 & 0 & 2 & 10 \\ 0 & 0 & 0 & 0 & 0 & 0 & 0 & 1 & 0 & 7 & 11 \\ 0 & 0 & 0 & 0 & 0 & 0 & 0 & 2 & 0 & 8 & 33 \\ 0 & 0 & 0 & 0 & 0 & 0 & 0 & 3 & 0 & 11 & 6 \\ 0 & 0 & 0 & 0 & 0 & 0 & 0 & 4 & 0 & 18 & 5 \\ 0 & 0 & 0 & 0 & 0 & 0 & 0 & 1 & 0 & 11 & 19 \\ 0 & 0 & 0 & 0 & 0 & 0 & 0 & 1 & 0 & 9 & 24 \\ 1 & 0 & 0 & 4 & 17 & 2 & 3 & 18 & 0 & 9 & 1\end{array}$

Totaal 
Tabel A5.3

Belangrijkste opleidingen van schoolverlaters die een vervolgopleiding zijn gaan volgen

HAVO

HBO B Opleiding leraar basisonderwijs

$\begin{array}{lr}\text { HBO B Opleiding tot Verpleegkundige } & 7\end{array}$

Vwo

WO B Geneeskunde

WO B Psychologie

VMBO theoretische leerweg

HAVO

VMBO landbouw

BOL BB Dierverzorging

VMBO gezondheidszorg

BOL ZB Sociaal-pedagogisch werk

BOL BB Helpende (welzijn)

BOL ZB Verzorgende

BOL ZB All-round kapper

BOL MKF Sociaal-pedagogisch werk

BOL niveau 1 totaal

BOL BB Autotechnicus

BOL BB Secretarieel

BBL ZB Verzorgende

BOL niveau 2 techniek

BOL MKF ICT beheerder servicedesk

BBL ZB Voortgezette timmerkracht

BOL ZB Informatietechniek

BBL BB Chauffeur goederenvervoer

BOL niveau 2 economie

BBL ZB Zelfstandig werkend kok

BOL niveau 2 gezondheidszorg

BOL ZB Sociaal-pedagogisch werk

-

\begin{tabular}{lr}
$B B L$ ZBV Verzorgende & 7 \\
\hline
\end{tabular}

BOL niveau 3 economie

HBO B Bedrijfseconomie

BOL niveau 3 gezondheidszorg

BOL MKF Verpleegkundige

BBL MKF Verpleegkundige

BOL ZB Uiterlijke verzorging

BOL niveau 3 gedrag en maatschappij

HBO B Maatschappelijk Werk en Dienstverlening 14

HBO B Opleiding leraar basisonderwijs $\quad 12$

BOL MKF Sociaal-pedagogisch werk $\quad 10$

BOL MKF Onderwijsassistent

HBO B Sociaal Pedagogische Hulpverlening

HBO Leraar basisonderwijs 
Tabel A5.3

Belangrijkste opleidingen van schoolverlaters die een vervolgopleiding zijn gaan volgen

BOL niveau 4 landbouw

$\mathrm{HBO} B$ Dier- en veehouderij

$H B O B$ Bedrijfskunde en Agribusiness

HBO B Tuin- en landschapsinrichting

BOL niveau 4 techniek

HBO B Bouwkunde

HBO B Elektrotechniek

HBO B Werktuigbouwkunde

HBO B Technische Bedrijfskunde

BOL niveau 4 economie

HBO B Commerciële Economie

$\mathrm{HBO}$ B Bedrijfseconomie

HBO B Management, Economie en Recht

BOL niveau 4 gezondheidszorg

HBO B Opleiding tot Verpleegkundige

HBO B Opl. tot Fysiotherapeut

HBO B Sport en Bewegen

BOL niveau 4 gedrag en maatschappij

HBO B Opleiding leraar basisonderwijs

HBO B Sociaal Pedagogische Hulpverlening

HBO B Maatschappelijk Werk en Dienstverlening

BBL niveau 2 totaal

BBL ZB Voortgezette timmerkracht

BBL ZB Verzorgende

BBL niveau 3 totaal

BBL ZB Verzorgende bij inst. voor gezinsverz.

BBL niveau 4 totaal

HBO B Opleiding tot Verpleegkundige

BBL MKF Detailhandel/ambulante handel

HBO B Ruimtelijke Ordening en Planologie

HBO B Sociaal Pedagogische Hulpverlening

HBO landbouw

WO M Animal Sciences and Aquaculture

WO Pre Master Opleiding

$\mathrm{HBO}$ onderwijs

HBO Master Onderwijs

WO Pre Master Opleiding

HBO B Sport en Bewegingseducatie

WO B Pedagogische Wetenschappen

\section{HBO techniek}

WO Pre Master Opleiding

$\mathrm{HBO}$ economie

WO Pre Master Opleiding

$\mathrm{HBO}$ gezondheidszorg

WO Pre Master Opleiding

WO B Psychologie 
Tabel A5.3

Belangrijkste opleidingen van schoolverlaters die een vervolgopleiding zijn gaan volgen

HBO gedrag en maatschappij

WO Pre Master Opleiding

WO B Nederlands Recht

WO B Psychologie

HBO taal en cultuur

HBO M Muziek

HBO 2e Fase Muziek

W0 landbouw

AlO/010

W0 Kort Onderwijs

W0 techniek

AlO/0I0

W0 economie

Post-doct. beroepsopl. Registeraccountant 13

AI0/0I0

Post-doct. beroepsopl. Accountant

W0 gezondheidszorg

Al0/010

Post-doct. beroepsopl. Huisarts

WO M Geneeskunde

Post-doct. beroepsopl. Interne geneeskunde

W0 gedrag en maatschappij

Al0/0I0

WO Kort Onderwijs

W0 taal en cultuur

WO Kort Onderwijs

AlO/0I0

W0 recht en openbare orde

Post-doct. beroepsopl. Advocatuur

Post-doct. beroepsopl. Belastingadviseur

Al0/0I0

Post-doct. beroepsopl. Kandidaat notaris opleiding

WO natuurwetenschappen

Al0/010

WO Kort Onderwijs

Toelichting

In de tabel zijn alleen die opleidingen opgenomen die door ten minste 5\% van de schoolverlaters worden gevolgd. 
Tabel A5.4

Doorstroom van schoolverlaters naar kenniscentrum beroepsonderwijs bedrijfsleven

HAVO

Calibris

Stichting ECABO

Kenniscentrum GOC

KC Handel

Innovam Groep

vwo

Stichting ECABO

VMBO theoretische leerweg

Calibris

Stichting ECABO

Stichting Kenwerk

KOC Nederland

KC Handel

VMBO landbouw

AEQUOR

Calibris

Stichting Kenwerk

Stichting ECABO

VMBO techniek

Kenteq

Fundeon

Stichting ECABO

Innovam Groep

VMBO economie

Stichting ECABO

Stichting Kenwerk

Calibris

KC Handel

KOC Nederland

VMBO gezondheidszorg

Calibris

KOC Nederland

Stichting Kenwerk

BOL niveau 1 totaal

Stichting ECABO

Calibris

Innovam Groep

Stichting Kenwerk

Savantis

Kenteq

KC Handel

BOL niveau 2 techniek

Kenteq

24

Fundeon

Stichting ECABO

Kenniscentrum $\mathrm{GOC}$

Innovam Groep

VTL 
Tabel A5.4

Doorstroom van schoolverlaters naar kenniscentrum beroepsonderwijs bedrijfsleven

BOL niveau 2 economie

Stichting ECABO

Stichting Kenwerk

KC Handel

Calibris

BOL niveau 2 gezondheidszorg

Calibris

KOC Nederland

BOL niveau 3 economie

Stichting ECABO

Kenniscentrum $\mathrm{GOC}$

KC Handel

Calibris

BOL niveau 3 gezondheidszorg

Calibris

KOC Nederland

BOL niveau 3 gedrag en maatschappij

Calibris

Stichting ECABO

BOL niveau 4 landbouw

AEQUOR

BOL niveau 4 techniek

Kenteq

SH\&M

Innovam Groep

Kenniscentrum PMLF

BOL niveau 4 economie

Stichting ECABO

KC Handel

Calibris

Stichting Kenwerk

BOL niveau 4 gezondheidszorg

Calibris

Fundeon

SVGB

BOL niveau 4 gedrag en maatschappij

Calibris

Stichting ECABO

KC Handel

BBL niveau 2 totaal

Kenteq

Fundeon

Calibris

Innovam Groep

Kenniscentrum VOC

SH\&M 
Tabel A5.4

Doorstroom van schoolverlaters naar kenniscentrum beroepsonderwijs bedrijfsleven

BBL niveau 3 totaal

Kenteq

23

Calibris

Fundeon

Stichting ECABO

BBL niveau 4 totaal

KC Handel

Calibris

Innovam Groep

Toelichting

In de tabel zijn alleen die kenniscentra opgenomen die door ten minste $5 \%$ van de schoolverlaters worden gevolgd. 
Tabel A5.5

Oordeel van schoolverlaters over de aansluiting van de afgesloten opleiding met de vervolgopleiding

\begin{tabular}{|c|c|c|c|c|}
\hline Opleidingssector & $\begin{array}{r}\text { goed } \\
\%\end{array}$ & $\begin{array}{r}\text { voldoende } \\
\%\end{array}$ & $\begin{array}{r}\text { matig } \\
\%\end{array}$ & $\begin{array}{r}\text { slecht } \\
\%\end{array}$ \\
\hline HAVO/VWO & 30 & 41 & 24 & 6 \\
\hline HAVO & 26 & 42 & 25 & 7 \\
\hline VW0 & 35 & 39 & 22 & 4 \\
\hline VMBO & 39 & 38 & 16 & 6 \\
\hline Naarleerweg & & & & \\
\hline Theoretisch & 38 & 38 & 18 & 6 \\
\hline Gemengd & 37 & 36 & 21 & 6 \\
\hline Kaderberoepsgericht & 37 & 42 & 14 & 7 \\
\hline Basisberoepsgericht & 45 & 35 & 14 & 7 \\
\hline \multicolumn{5}{|l|}{ Naar sector } \\
\hline Landbouw & 32 & 44 & 16 & 8 \\
\hline Techniek & 41 & 37 & 15 & 7 \\
\hline Economie & 37 & 40 & 15 & 8 \\
\hline Gezondheidszorg & 44 & 37 & 14 & 6 \\
\hline $\mathrm{BOL}$ & 30 & 39 & 20 & 11 \\
\hline BoL niveau 1 & 56 & 22 & 9 & 13 \\
\hline B0L niveau 2 & 42 & 37 & 14 & 7 \\
\hline Techniek & 33 & 46 & 13 & 7 \\
\hline Economie & 46 & 34 & 15 & 6 \\
\hline Gezondheidszorg & 43 & 35 & 14 & 8 \\
\hline B0L niveau 3 & 30 & 39 & 20 & 11 \\
\hline Economie & 27 & 39 & 24 & 9 \\
\hline Gezondheidszorg & 30 & 40 & 12 & 18 \\
\hline Gedrag en maatschappij & 32 & 41 & 20 & 7 \\
\hline B0L niveau 4 & 25 & 40 & 23 & 12 \\
\hline Landbouw & 23 & 44 & 21 & 12 \\
\hline Techniek & 22 & 43 & 23 & 12 \\
\hline Economie & 27 & 37 & 23 & 12 \\
\hline Gezondheidszorg & 24 & 41 & 27 & 9 \\
\hline Gedrag en maatschappij & 25 & 40 & 22 & 12 \\
\hline BBL & 51 & 30 & 14 & 5 \\
\hline BBL niveau 2 & 58 & 30 & 10 & 2 \\
\hline BBL niveau 3 & 45 & 32 & 14 & 9 \\
\hline BBL niveau 4 & 38 & 26 & 28 & 8 \\
\hline Totaal & 35 & 39 & 19 & 7 \\
\hline
\end{tabular}

Toelichting

Vraag in de enquête:

Hoe is de aansluiting tussen de gevolgde [...] opleiding en deze vervolgopleiding? 
Tabel A6.1

Uitvallers en studiewisselaars

\begin{tabular}{|c|c|c|}
\hline Opleidingssector & $\begin{array}{r}\text { vervolgopleiding voortijdig } \\
\text { verlaten } \\
\%\end{array}$ & studiewisselaar \\
\hline HAVO/VWO & 14 & 11 \\
\hline HAVO & 15 & 12 \\
\hline vw0 & 13 & 11 \\
\hline VMBO & 11 & 7 \\
\hline Naarleerweg & & \\
\hline Theoretisch & 10 & 8 \\
\hline Gemengd & 6 & 5 \\
\hline Kaderberoepsgericht & 13 & 8 \\
\hline Basisberoepsgericht & 10 & 6 \\
\hline Naar sector & & \\
\hline Landbouw & 10 & 6 \\
\hline Techniek & 11 & 6 \\
\hline Economie & 14 & 9 \\
\hline Gezondheidszorg & 10 & 6 \\
\hline BOL & 11 & 3 \\
\hline B0L niveau 1 & 14 & 3 \\
\hline BOL niveau 2 & 7 & 2 \\
\hline Techniek & 5 & 0 \\
\hline Economie & 7 & 2 \\
\hline Gezondheidszorg & 9 & 3 \\
\hline BOL niveau 3 & 13 & 4 \\
\hline Economie & 12 & 5 \\
\hline Gezondheidszorg & 9 & 0 \\
\hline Gedrag en maatschappij & 15 & 5 \\
\hline BOL niveau 4 & 12 & 4 \\
\hline Landbouw & 14 & 5 \\
\hline Techniek & 11 & 4 \\
\hline Economie & 13 & 5 \\
\hline Gezondheidszorg & 9 & 2 \\
\hline Gedrag en maatschappij & 12 & 3 \\
\hline BBL & 8 & 2 \\
\hline BBL niveau 2 & 7 & 2 \\
\hline BBL niveau 3 & 7 & 1 \\
\hline BBL niveau 4 & 8 & 2 \\
\hline HBO & 8 & 1 \\
\hline Landbouw & 7 & 0 \\
\hline Onderwijs & 6 & 1 \\
\hline Techniek & 10 & 1 \\
\hline Economie & 7 & 1 \\
\hline Gezondheidszorg & 7 & 0 \\
\hline Gedrag en maatschappij & 8 & 0 \\
\hline Taal en cultuur & 5 & 1 \\
\hline
\end{tabular}


Statistische Bijlage

Tabel A6.1

Uitvallers en studiewisselaars

Opleidingssector

vervolgopleiding voortijdig

verlaten

studiewisselaar

$\%$

$\%$

W0

Landbouw

Techniek

Economie

Gezondheidszorg

Gedrag en maatschappij

Taal en cultuur

Recht en openbare orde

Natuurwetenschappen

$\begin{array}{ll}5 & 0 \\ 1 & 0 \\ 4 & 0 \\ 5 & 0 \\ 2 & 0 \\ 6 & 0 \\ 8 & 0 \\ 5 & 1 \\ 5 & 0 \\ 11 & 0\end{array}$

Totaal 
Tabel A7.1

Opleiding achteraf opnieuw kiezen: doorstroom naar vervolgonderwijs

\begin{tabular}{|c|c|c|c|}
\hline Opleidingssector & $\begin{array}{r}\text { zelfde } \\
\text { opleiding } \\
\%\end{array}$ & $\begin{array}{r}\text { andere } \\
\text { opleiding } \\
\%\end{array}$ & $\begin{array}{r}\text { geen } \\
\text { opleiding } \\
\%\end{array}$ \\
\hline VMBO & 85 & 15 & 0 \\
\hline Naarleerweg & & & \\
\hline Theoretisch & 88 & 12 & 0 \\
\hline Gemengd & 87 & 13 & 0 \\
\hline Kaderberoepsgericht & 84 & 16 & 0 \\
\hline Basisberoepsgericht & 81 & 19 & 0 \\
\hline Naar sector & & & \\
\hline Landbouw & 82 & 18 & 0 \\
\hline Techniek & 78 & 22 & 0 \\
\hline Economie & 84 & 16 & 0 \\
\hline Gezondheidszorg & 87 & 13 & 0 \\
\hline $\mathrm{BOL}$ & 80 & 18 & 2 \\
\hline BoL niveau 1 & 80 & 12 & 8 \\
\hline BOL niveau 2 & 71 & 22 & 8 \\
\hline Techniek & 62 & 23 & 14 \\
\hline Economie & 76 & 22 & 2 \\
\hline Gezondheidszorg & 72 & 20 & 8 \\
\hline BOL niveau 3 & 78 & 20 & 2 \\
\hline Economie & 78 & 20 & 2 \\
\hline Gezondheidszorg & 76 & 24 & 0 \\
\hline Gedrag en maatschappij & 84 & 14 & 2 \\
\hline BoL niveau 4 & 82 & 17 & 1 \\
\hline Landbouw & 85 & 15 & 0 \\
\hline Techniek & 81 & 18 & 1 \\
\hline Economie & 78 & 20 & 2 \\
\hline Gezondheidszorg & 86 & 13 & 1 \\
\hline Gedrag en maatschappij & 86 & 14 & 0 \\
\hline BBL & 80 & 16 & 4 \\
\hline BBL niveau 2 & 85 & 9 & 7 \\
\hline BBL niveau 3 & 80 & 19 & 1 \\
\hline BBL niveau 4 & 67 & 31 & 2 \\
\hline HBO & 78 & 21 & 0 \\
\hline Landbouw & 77 & 22 & 2 \\
\hline Onderwijs & 85 & 15 & 0 \\
\hline Techniek & 79 & 20 & 1 \\
\hline Economie & 75 & 25 & 0 \\
\hline Gezondheidszorg & 80 & 20 & 0 \\
\hline Gedrag en maatschappij & 76 & 23 & 0 \\
\hline Taal en cultuur & 81 & 17 & 2 \\
\hline WO & 83 & 17 & 0 \\
\hline Landbouw & 80 & 20 & 0 \\
\hline Techniek & 82 & 18 & 0 \\
\hline Economie & 86 & 14 & 1 \\
\hline Gezondheidszorg & 90 & 10 & 0 \\
\hline Gedrag en maatschappij & 77 & 23 & 0 \\
\hline
\end{tabular}


Statistische Bijlage

Tabel A7.1

Opleiding achteraf opnieuw kiezen: doorstroom naar vervolgonderwijs

Opleidingssector

zelfde

opleiding

andere

opleiding

geen

$\%$

$\%$

opleiding

WO (vervolg)

Taal en cultuur

76

76
88

Recht en openbare orde

Natuurwetenschappen

82

23

11

17

83

16

1

Totaal

1 
Tabel A8.1

Belangrijkste bedrijfsgroepen waarin schoolverlaters werkzaam zijn

HAVO

Gezondheidszorg

Supermarkten, warenhuizen

Overheidsdiensten

Restaurants/cafetaria's/snackbars ed

Welzijnszorg

Winkels gespecialiseerd in overige artikelen

Ov. zakelijke dienstverlening n.e.g.

VW0

Rechtsk. dienstverl./account./belastingconsul./holdings ed 12

Winkels farmac./med. art./parfum/cosmetica 10

$\begin{array}{ll}\text { Winkels gespecialiseerd in overige artikelen } & 10\end{array}$

Overheidsdiensten

Supermarkten, warenhuizen

Grooth. ov. Consumentenartikelen

Ov. zakelijke dienstverlening n.e.g.

VMBO theoretische leerweg

Winkels gespecialiseerd in overige artikelen 11

$\begin{array}{ll}\text { Supermarkten, warenhuizen } & 10\end{array}$

Restaurants/cafetaria's/snackbars ed $\quad 10$

$\begin{array}{ll}\text { Overheidsdiensten } & 10\end{array}$

Gezondheidszorg $\quad 8$

Ov. dienstverlening

VMBO landbouw

Winkels gespecialiseerd in overige artikelen 12

Dienstverlening tbv landbouw 11

Bouwrijp maken terreinen $\quad 9$

\begin{tabular}{lr} 
Welzijnszorg & 8 \\
\hline
\end{tabular}

Supermarkten, warenhuizen $\quad 5$

VMBO techniek

Burgerlijke en utiliteitsbouw grond-/water-/wegenbouw 13

Afwerken gebouwen $\quad 10$

$\begin{array}{lr}\text { Bouwinstallatie } & 8\end{array}$

Vervaardiging metalen constructiew./ramen/deuren/kozijnen $\quad 6$

Overheidsdiensten

\section{VMBO economie}

Supermarkten, warenhuizen

Restaurants/cafetaria's/snackbars ed

Winkels gespecialiseerd in overige artikelen

\section{VMBO gezondheidszorg}

Ov. dienstverlening

Supermarkten, warenhuizen

Winkels gespecialiseerd in overige artikelen

BOL niveau 1 totaal

Overheidsdiensten 
Tabel A8.1

Belangrijkste bedrijfsgroepen waarin schoolverlaters werkzaam zijn

BOL niveau 2 landbouw

Winkels gespecialiseerd in overige artikelen

Fokken/houden dieren

BOL niveau 2 techniek

Bouwinstallatie

Burgerlijke en utiliteitsbouw grond-/water-/wegenbouw

Handel in, reparatie van auto's (1)

BOL niveau 2 economie

Overheidsdiensten

Restaurants/cafetaria's/snackbars ed

Beveiliging/opsporing

BOL niveau 2 gezondheidszorg

Welzijnszorg

Ov. dienstverlening

Supermarkten, warenhuizen

Overheidsdiensten

Hotels/pensions/conferentie-0orden

Gezondheidszorg

BOL niveau 3 landbouw

Dienstverlening tbv landbouw

Winkels gespecialiseerd in overige artikelen

Fokken/houden dieren

Akker-/tuinbouw

Sport

Welzijnszorg

BOL niveau 3 techniek

Vervoer over water

Overig amusement/kunst

Visserij/kweken vis/schaaldieren

Vervaardiging meubels

Binnenvaart

BOL niveau 3 economie

Reisorganisatie/-bemiddeling, informatieverstrekking toerisme

BOL niveau 3 gezondheidszorg

Gezondheidszorg

BOL niveau 3 gedrag en maatschappij

Welzijnszorg

BOL niveau 4 landbouw

Winkels gespecialiseerd in overige artikelen $\quad 17$

Dienstverlening tbv landbouw

Fokken/houden dieren

Cult. uitl.centra/openb. arch./musea/dieren-/plantentuin ed

BOL niveau 4 techniek 
Tabel A8.1

Belangrijkste bedrijfsgroepen waarin schoolverlaters werkzaam zijn

BOL niveau 4 techniek (vervolg)

Winkels gespecialiseerd in overige artikelen

Burgerlijke en utiliteitsbouw grond-/water-/wegenbouw

Vervoer over weg

Architecten-/ingenieurs-/ov. techn.ontw.-/teken-/adviesbureau

BOL niveau 4 economie

Rechtsk. dienstverl./account//belastingconsul./holdings ed

Winkels gespecialiseerd in overige artikelen

BOL niveau 4 gezondheidszorg

Gezondheidszorg

Welzijnszorg

Winkels farmac./med. art./parfum/cosmetica

BOL niveau 4 gedrag en maatschappij

Welzijnszorg

Gezondheidszorg

Primair onderwijs voor leerplichtingen en speciaal onderwijs

BBL niveau 1 totaal

Vervaardiging ov. goederen n.e.g.

Welzijnszorg

Handel in, reparatie van auto's (1)

BBL niveau 2 landbouw

Dienstverlening tbv landbouw

Vervaardiging ov. goederen n.e.g.

Winkels gespecialiseerd in overige artikelen

Fokken/houden dieren

Slachterijen/vleesverwerking

BBL niveau 2 techniek

Burgerlijke en utiliteitsbouw grond-/water-/wegenbouw

Bouwinstallatie

Afwerken gebouwen

Handel in, reparatie van auto's (1)

Vervoer over weg

BBL niveau 2 economie

Supermarkten, warenhuizen

Beveiliging/opsporing

Overheidsdiensten

Winkels farmac./med. art./parfum/cosmetica

Winkels gespecialiseerd in overige artikelen

Restaurants/cafetaria's/snackbars ed

BBL niveau 2 gezondheidszorg

Welzijnszorg

Ov. dienstverlening

Gezondheidszorg

BBL niveau 3 landbouw

Dienstverlening tbv landbouw

Winkels gespecialiseerd in overige artikelen

Vervaardiging zuivelprodukten

Vervaardiging voedingsmiddelen (overig)

Grooth. voedings-/genotmiddelen

Openbaar bestuur 
Tabel A8.1

Belangrijkste bedrijfsgroepen waarin schoolverlaters werkzaam zijn

BBL niveau 3 techniek

Burgerlijke en utiliteitsbouw grond-/water-/wegenbouw 21

Bouwinstallatie $\quad 19$

Handel in, reparatie van auto's (1) $\quad 7$

$\begin{array}{ll}\text { Afwerken gebouwen } & 5\end{array}$

BBL niveau 3 economie

Restaurants/cafetaria's/snackbars ed $\quad 20$

Supermarkten, warenhuizen $\quad 14$

Winkels gespecialiseerd in overige artikelen $\quad 11$

Hotels/pensions/conferentie-oorden $\quad 10$

$\begin{array}{lr}\text { Kampeerterreinen/ov. voorzien. recreat. verblijf n.e.g. } & 7\end{array}$

BBL niveau 3 gezondheidszorg

Welzijnszorg

Ov. dienstverlening

BBL niveau 3 gedrag en maatschappij

Welzijnszorg

Primair onderwijs voor leerplichtingen en speciaal onderwijs

BBL niveau 4 techniek

Burgerlijke en utiliteitsbouw grond-/water-/wegenbouw

Bouwinstallatie

Handel in, reparatie van auto's (1)

Welzijnszorg

Architecten-/ingenieurs-/ov. techn.ontw.-/teken-/adviesbureau

BBL niveau 4 economie

$\begin{array}{lr}\text { Winkels gespecialiseerd in overige artikelen } & 28\end{array}$

Supermarkten, warenhuizen 12

Architecten-/ingenieurs-/ov. techn.ontw.-/teken-/adviesbureau 9

BBL niveau 4 gezondheidszorg

Gezondheidszorg

BBL niveau 4 gedrag en maatschappij

Welzijnszorg

Gezondheidszorg

Primair onderwijs voor leerplichtingen en speciaal onderwijs

Overheidsdiensten

HBO landbouw

Architecten-/ingenieurs-/ov. techn.ontw.-/teken-/adviesbureau

Rechtsk. dienstverl./account./belastingconsul./holdings ed

Openbaar bestuur

Secundair onderwijs en educatie

$\mathrm{HB} 0$ onderwijs

Primair onderwijs voor leerplichtingen en speciaal onderwijs

\section{HBO techniek}

Architecten-/ingenieurs-/ov. techn.ontw.-/teken-/adviesbureau 
Tabel A8.1

Belangrijkste bedrijfsgroepen waarin schoolverlaters werkzaam zijn

HBO economie

Rechtsk. dienstverl./account./belastingconsul./holdings ed

Uitzendbur./uitleenbedr./arbeidsbemid./testen/werven/selectie

Geldscheppende financiele instellingen

HBO gezondheidszorg

Gezondheidszorg

Welzijnszorg

$\mathrm{HBO}$ gedrag en maatschappij

Welzijnszorg

Gezondheidszorg

Uitzendbur./uitleenbedr./arbeidsbemid./testen/werven/selectie

HBO taal en cultuur

Overig amusement/kunst

Reclamebureaus ed

$0 v$. zakelijke dienstverlening n.e.g.

Secundair onderwijs en educatie

wo landbouw

Tertiair onderwijs

Architecten-/ingenieurs-/ov. techn.ontw.-/teken-/adviesbureau

Natuurwetenschappelijk speur-/ontwikkelingswerk

Openbaar bestuur

Gezondheidszorg

Rechtsk. dienstverl./account//belastingconsul./holdings ed

\section{W0 techniek}

Architecten-/ingenieurs-/ov. techn.ontw.-/teken-/adviesbureau

Tertiair onderwijs

Ontwikkelen/produceren/uitgeven software, softwareconsultancy

Rechtsk. dienstverl./account./belastingconsul./holdings ed

\section{(1)}

w0 economie

Rechtsk. dienstverl./account./belastingconsul./holdings ed

Geldscheppende financiele instellingen

W0 gezondheidszorg

Gezondheidszorg

Tertiair onderwijs

W0 gedrag en maatschappij

Gezondheidszorg

Welzijnszorg

Rechtsk. dienstverl./account//belastingconsul./holdings ed

Openbaar bestuur

Tertiair onderwijs

Overheidsdiensten

WO taal en cultuur

Tertiair onderwijs

Rechtsk. dienstverl./account./belastingconsul./holdings ed

Uitgeverijen

Openbaar bestuur

Secundair onderwijs en educatie

Levensbesch-, politieke -, ideele organisaties 
Tabel A8.1

Belangrijkste bedrijfsgroepen waarin schoolverlaters werkzaam zijn

W0 recht en openbare orde

Rechtsk. dienstverl./account./belastingconsul./holdings ed 49

Overheidsdiensten $\quad 16$

$\begin{array}{lr}\text { Openbaar bestuur } & 9\end{array}$

W0 natuurwetenschappen

$\begin{array}{ll}\text { Winkels farmac./med. art./parfum/cosmetica } & 7\end{array}$

$\begin{array}{ll}\text { Tertiair onderwijs } & 21\end{array}$

$\begin{array}{lr}\text { Rechtsk. dienstverl./account./belastingconsul./holdings ed } & 9\end{array}$

Ontwikkelen/produceren/uitgeven software, softwareconsultancy $\quad 10$

Natuurwetenschappelijk speur-/ontwikkelingswerk $\quad 5$

$\begin{array}{ll}\text { Gezondheidszorg } & 9\end{array}$

Toelichting

De bedrijven waarin de schoolverlaters werkzaam zijn, zijn geclassificeerd volgens de Standaard Bedrijfs Indeling van het CBS. Op het hier gepresenteerde niveau van bedrijfsgroepen worden in totaal 211 categorieën onderscheiden.

In de tabel zijn alleen die bedrijfsgroepen weergegeven waarin ten minste $5 \%$ van de schoolverlaters werkzaam is. 
Tabel A8.2

Belangrijkste beroepsgroepen waarin schoolverlaters werkzaam zijn

HAVO

Elementaire beroepen

Verkopers

Hulpkrachten horeca en verzorging

Productieplanners

Politieagenten, onderofficieren en beveiligingsemployés

Verpleeghulpen en leerling-verpleegkundigen

Verplegenden en doktersassistenten

VWO

Elementaire beroepen

Assistent accountants

Commercieel employés

Receptionisten en administratieve employés

VMBO theoretische leerweg

Verkopers

Elementaire beroepen

Hulpkrachten horeca en verzorging

Aspirant politieagenten, soldaten en beveiligingshulpkrachten

Verzorgend personeel

\section{VMBO landbouw}

Verkopers

Elementaire beroepen

Agrarische arbeider

Hulpkrachten horeca en verzorging

Weg- en waterbouwkundige vakkrachten

Verzorgend personeel

VMBO techniek

Bouwvakkers

-

\begin{tabular}{ll} 
Elementaire beroepen & 10 \\
\hline
\end{tabular}

Metaalarbeiders $\quad 9$

Assembleurs

Monteurs

Aspirant politieagenten, soldaten en beveiligingshulpkrachten

VMBO economie

Verkopers

Elementaire beroepen

Verzorgend personee

Hulpkrachten horeca en verzorging

VMBO gezondheidszorg

Verkopers

Hulpkrachten horeca en verzorging $\quad 20$

Verzorgend personeel

BOL niveau 1 totaal

Elementaire beroepen

Aspirant politieagenten, soldaten en beveiligingshulpkrachten

Bouwvakkers

Hulpkrachten horeca en verzorging

Verzorgend personeel

Verkopers 
Tabel A8.2

Belangrijkste beroepsgroepen waarin schoolverlaters werkzaam zijn

BOL niveau 2 landbouw

Agrarische arbeider

Agrarische vakkrachten

BOL niveau 2 techniek

Elementaire beroepen

Bouwvakkers

Monteurs

Chauffeurs

Bankwerkers en lassers

BOL niveau 2 economie

Aspirant politieagenten, soldaten en beveiligingshulpkrachten $\quad 25$

Boekhouders en secretaresses $\quad 12$

\begin{tabular}{ll} 
Verkopers & 10 \\
\hline
\end{tabular}

$\begin{array}{lr}\text { Hulpkrachten horeca en verzorging } & 8\end{array}$

Elementaire beroepen

Receptionisten en administratieve employés

BOL niveau 2 gezondheidszorg

Verzorgend personeel

Hulpkrachten horeca en verzorging

Elementaire beroepen

Verkopers

Aspirant politieagenten, soldaten en beveiligingshulpkrachten

BOL niveau 3 landbouw

Agrarische arbeider

Agrarische bedrijfshoofden

Agrarische vakkrachten

Verkopers

Hulpkrachten horeca en verzorging

BOL niveau 3 techniek

Schippers en conducteurs

Elektromonteurs

Weg- en waterbouwkundige vakkrachten

Landbouwmachinebestuurders en vissers

Laboranten

Aannemers en installateurs

Procestechnische beroepen (mid)

Chauffeurs

Grafische vakkrachten

BOL niveau 3 economie

Boekhouders en secretaresses

Commercieel employés

Receptionisten en administratieve employés

Programmeurs

BOL niveau 3 gezondheidszorg

Verzorgend personeel

Verplegenden en doktersassistenten

Verkopers 
Tabel A8.2

Belangrijkste beroepsgroepen waarin schoolverlaters werkzaam zijn

BOL niveau 3 gedrag en maatschappij

Verzorgend personeel

Activiteitenbegeleiders en medewerkers arbeidsbemiddeling

Hulpkrachten horeca en verzorging

BOL niveau 4 landbouw

Agrarische arbeider

18

Verplegenden en doktersassistenten

Verkopers

13

Agrarische vakkrachten

Agrarische bedrijfshoofden

BOL niveau 4 techniek

Monteurs

Productieplanners

Aannemers en installateurs

Elektromonteurs

Procestechnische beroepen (mid)

B0L niveau 4 economie

Boekhouders en secretaresses

Commercieel employés

Verkopers

Receptionisten en administratieve employés

Programmeurs

Winkeliers

BOL niveau 4 gezondheidszorg

Verplegenden en doktersassistenten

Apothekersassistenten en medisch laboranten

Verzorgend personeel

BOL niveau 4 gedrag en maatschappij

Verzorgend personeel

Activiteitenbegeleiders en medewerkers arbeidsbemiddeling

Verplegenden en doktersassistenten

BBL niveau 1 totaal

Elementaire beroepen

Chauffeurs

Hulpkrachten horeca en verzorging

Agrarische arbeider

Bouwvakkers

Verkopers

Procestechnische beroepen (mid)

BBL niveau 2 landbouw

Agrarische arbeider

Agrarische vakkrachten

Bouwvakkers

Procestechnische beroepen (mid)

Elementaire beroepen

Mechanisch operators

Verkopers

Agrarische bedrijfshoofden

BBL niveau 2 techniek

Aannemers en installateurs

Monteurs 
Tabel A8.2

Belangrijkste beroepsgroepen waarin schoolverlaters werkzaam zijn

BBL niveau 2 techniek (vervolg)

Bouwvakkers

Chauffeurs

Elementaire beroepen

Metaalarbeiders

Monteurs en controleurs elektrotechnische producten

BBL niveau 2 economie

Aspirant politieagenten, soldaten en beveiligingshulpkrachten 22

Verkopers

Winkeliers

Elementaire beroepen

Hulpkrachten horeca en verzorging

BBL niveau 2 gezondheidszorg

Verzorgend personeel

Hulpkrachten horeca en verzorging

Activiteitenbegeleiders en medewerkers arbeidsbemiddeling

BBL niveau 3 landbouw

Agrarische arbeider

Agrarische vakkrachten

Procestechnische beroepen (mid)

Bouwvakkers

Agrarische bedrijfshoofden

Chauffeurs

Verkopers

BBL niveau 3 techniek

Aannemers en installateurs

Monteurs

Bouwvakkers

Procestechnische beroepen (mid)

Elektromonteurs

Apothekersassistenten en medisch laboranten

BBL niveau 3 economie

Verzorgend personeel

Verkopers

Winkeliers

Hulpkrachten horeca en verzorging

Boekhouders en secretaresses

BBL niveau 3 gezondheidszorg

Verzorgend personeel

Ziekenverzorgenden

BBL niveau 3 gedrag en maatschappij

Verzorgend personeel

Activiteitenbegeleiders en medewerkers arbeidsbemiddeling

Hulpkrachten horeca en verzorging

BBL niveau 4 techniek

Monteurs

Aannemers en installateurs

Elektromonteurs

Bouwvakkers

Elektronicamonteurs

Productieplanners

Verzorgend personeel 
Tabel A8.2

Belangrijkste beroepsgroepen waarin schoolverlaters werkzaam zijn

BBL niveau 4 economie

Winkeliers

33

Boekhouders en secretaresses

Verkopers

Commercieel employés

Verzorgend personeel

BBL niveau 4 gezondheidszorg

Verplegenden en doktersassistenten

Apothekersassistenten en medisch laboranten

12

Verzorgend personeel

BBL niveau 4 gedrag en maatschappij

Activiteitenbegeleiders en medewerkers arbeidsbemiddeling 41

Verzorgend personeel

Verplegenden en doktersassistenten

HBO landbouw

Milieuhygienisten en agrarisch vertegenwoordigers

Commercieel medewerkers

Organisatie-adviseurs

Assistent accountants

Agrarische bedrijfshoofden

HBO onderwijs

Leraar basisonderwijs

Docenten talen en expressie

Docenten sociale vakken (2e en 3e gr.)

HBO techniek

Systeemanalisten

Architecten en bouwkundig projectleiders

Werktuigbouwkundig ontwerpers en hoofden technische dienst

Technisch systeemanalisten

Organisatie-adviseurs

HBO economie

Commercieel medewerkers

Assistent accountants

Commercieel employés

Organisatie-adviseurs

Systeemanalisten

Sociaal-cultureel werkers

\section{HBO gezondheidszorg}

Therapeuten en verpleegkundigen

Verplegenden en doktersassistenten

$\mathrm{HBO}$ gedrag en maatschappij

Sociaal-cultureel werkers

Activiteitenbegeleiders en medewerkers arbeidsbemiddeling

Verzorgend personeel

Organisatie-adviseurs

$\mathrm{HBO}$ taal en cultuur 
Tabel A8.2

Belangrijkste beroepsgroepen waarin schoolverlaters werkzaam zijn

WO landbouw

Natuurwetenschappers

Landbouwkundigen

Milieuhygienisten en agrarisch vertegenwoordigers

Artsen

17

W0 techniek

Weg- en waterbouwkundigen

Materiaalkundigen

Informatici

Systeemanalisten

Organisatiedeskundigen

Architecten en bouwkundig projectleiders

W0 economie

$\begin{array}{ll}\text { Commercieel medewerkers } & 18\end{array}$

Economen $\quad 13$

$\begin{array}{ll}\text { Organisatiedeskundigen } & 13\end{array}$

$\begin{array}{lr}\text { Accountants } & 10\end{array}$

Assistent accountants

Organisatie-adviseurs

Managers

W0 gezondheidszorg

Artsen

W0 gedrag en maatschappij

$\begin{array}{ll}\text { Sociaal-wetenschappelijk onderzoekers } & 17\end{array}$

Sociaal-cultureel werkers

Onderwijskundigen en pedagogen

Commercieel medewerkers

Organisatiedeskundigen

W0 taal en cultuur

Commercieel medewerkers

Journalisten

Docenten letteren (1e gr. en W0)

Taalkundigen

W0 recht en openbare orde

Juristen

Managers

Juridisch, bestuurlijk medewerkers

\section{W0 natuurwetenschappen}

Systeemanalisten

Natuurwetenschappers

Apothekers

Informatici

Organisatiedeskundigen

\section{Toelichting}

De beroepen waarin de schoolverlaters werkzaam zijn, zijn geclassificeerd volgens de Standaard Beroepenclassificatie 1992 van het CBS. Binnen de elementaire beroepen is hierbij door het ROA een nader onderscheid gemaakt. Bovendien zijn de namen van de beroepen verduidelijkt. Op het hier gepresenteerde niveau van beroepsgroepen worden in totaal 127 categorieën onderscheiden.

In de tabel zijn alleen die beroepsgroepen weergegeven waarin ten minste $5 \%$ van de schoolverlaters werkzaam is. 
Tabel A8.3

Grootte van de organisatie waarin schoolverlaters werkzaam zijn

\begin{tabular}{|c|c|c|c|c|c|c|c|}
\hline Opleidingssector & $\begin{array}{r}1 \mathrm{t} / \mathrm{m} 9 \\
\text { pers. } \\
\%\end{array}$ & $\begin{array}{r}10 \mathrm{t} / \mathrm{m} 24 \\
\text { pers. } \\
\%\end{array}$ & $\begin{array}{r}25 \mathrm{t} / \mathrm{m} 49 \\
\text { pers. } \\
\%\end{array}$ & $\begin{array}{r}50 \mathrm{t} / \mathrm{m} 99 \\
\text { pers. } \\
\%\end{array}$ & $\begin{array}{r}100 \text { t/m } 249 \\
\text { pers. } \\
\%\end{array}$ & $\begin{array}{r}250 \mathrm{t} / \mathrm{m} 999 \\
\text { pers. } \\
\%\end{array}$ & $\begin{array}{r}\geq 1000 \\
\text { pers } \\
\%\end{array}$ \\
\hline HAVO/VWO & 13 & 12 & 12 & 13 & 11 & 16 & 24 \\
\hline HAVO & 14 & 12 & 10 & 13 & 8 & 17 & 25 \\
\hline vwo & 10 & 10 & 15 & 11 & 20 & 12 & 22 \\
\hline $\begin{array}{l}\text { VMBO } \\
\text { Naarleerweg }\end{array}$ & 21 & 20 & 13 & 9 & 8 & 9 & 19 \\
\hline Theoretisch & 16 & 22 & 12 & 8 & 4 & 8 & 30 \\
\hline Gemengd & 19 & 15 & 5 & 9 & 13 & 17 & 22 \\
\hline Kaderberoepsgericht & 20 & 21 & 11 & 11 & 10 & 9 & 18 \\
\hline Basisberoepsgericht & 26 & 18 & 16 & 9 & 9 & 9 & 12 \\
\hline Naar sector & & & & & & & \\
\hline Landbouw & 23 & 20 & 7 & 15 & 10 & 8 & 17 \\
\hline Techniek & 25 & 23 & 13 & 7 & 9 & 9 & 15 \\
\hline Economie & 19 & 15 & 17 & 13 & 11 & 12 & 14 \\
\hline Gezondheidszorg & 24 & 18 & 13 & 9 & 9 & 10 & 16 \\
\hline BOL & 16 & 14 & 10 & 8 & 11 & 16 & 25 \\
\hline BOL niveau 1 & 21 & 11 & 12 & 3 & 16 & 17 & 21 \\
\hline BOL niveau 2 & 16 & 15 & 11 & 7 & 10 & 14 & 27 \\
\hline Landbouw & 24 & 33 & 14 & 5 & 5 & 5 & 14 \\
\hline Techniek & 25 & 11 & 16 & 10 & 9 & 12 & 17 \\
\hline Economie & 13 & 15 & 8 & 6 & 10 & 12 & 37 \\
\hline Gezondheidszorg & 11 & 18 & 11 & 6 & 11 & 22 & 21 \\
\hline BOL niveau 3 & 16 & 14 & 12 & 10 & 12 & 16 & 21 \\
\hline Landbouw & 57 & 7 & 9 & 8 & 5 & 4 & 10 \\
\hline Techniek & 35 & 16 & 11 & 8 & 14 & 10 & 5 \\
\hline Economie & 13 & 14 & 12 & 8 & 12 & 14 & 27 \\
\hline Gezondheidszorg & 11 & 11 & 9 & 10 & 9 & 22 & 28 \\
\hline Gedrag en maatschappij & 9 & 17 & 13 & 12 & 14 & 18 & 17 \\
\hline BOL niveau 4 & 15 & 13 & 9 & 8 & 10 & 17 & 27 \\
\hline Landbouw & 50 & 16 & 5 & 3 & 8 & 7 & 12 \\
\hline Techniek & 14 & 13 & 11 & 11 & 14 & 14 & 22 \\
\hline Economie & 19 & 12 & 8 & 10 & 10 & 14 & 27 \\
\hline Gezondheidszorg & 13 & 17 & 9 & 3 & 4 & 17 & 37 \\
\hline Gedrag en maatschappij & 6 & 11 & 10 & 8 & 10 & 26 & 29 \\
\hline $\mathrm{BBL}$ & 13 & 11 & 9 & 8 & 11 & 20 & 28 \\
\hline BBL niveau 1 & 11 & 7 & 6 & 8 & 15 & 26 & 28 \\
\hline BBL niveau 2 & 15 & 12 & 10 & 8 & 11 & 18 & 25 \\
\hline Landbouw & 20 & 17 & 10 & 3 & 12 & 12 & 25 \\
\hline Techniek & 20 & 17 & 13 & 10 & 10 & 14 & 15 \\
\hline Economie & 10 & 6 & 9 & 7 & 14 & 20 & 35 \\
\hline Gezondheidszorg & 7 & 10 & 3 & 5 & 8 & 31 & 36 \\
\hline BBL niveau 3 & 14 & 10 & 10 & 11 & 13 & 19 & 23 \\
\hline Landbouw & 28 & 11 & 17 & 6 & 22 & 11 & 6 \\
\hline Techniek & 20 & 17 & 14 & 12 & 12 & 11 & 13 \\
\hline Economie & 20 & 14 & 11 & 17 & 7 & 9 & 22 \\
\hline Gezondheidszorg & 6 & 1 & 5 & 8 & 13 & 29 & 38 \\
\hline Gedrag en maatschappij & 7 & 12 & 11 & 10 & 19 & 31 & 10 \\
\hline
\end{tabular}


Tabel A8.3

Grootte van de organisatie waarin schoolverlaters werkzaam zijn

\begin{tabular}{|c|c|c|c|c|c|c|c|}
\hline Opleidingssector & $\begin{array}{r}1 \mathrm{t} / \mathrm{m} 9 \\
\text { pers. } \\
\%\end{array}$ & $\begin{array}{r}10 \mathrm{t} / \mathrm{m} 24 \\
\text { pers. } \\
\%\end{array}$ & $\begin{array}{r}25 \mathrm{t} / \mathrm{m} 49 \\
\text { pers. } \\
\%\end{array}$ & $\begin{array}{r}50 \mathrm{t} / \mathrm{m} 99 \\
\text { pers. } \\
\%\end{array}$ & $\begin{array}{r}100 \mathrm{t} / \mathrm{m} 249 \\
\text { pers. } \\
\%\end{array}$ & $\begin{array}{r}250 \mathrm{t} / \mathrm{m} 999 \\
\text { pers. } \\
\%\end{array}$ & $\begin{array}{r}\geq 1000 \\
\text { pers } \\
\%\end{array}$ \\
\hline BBL niveau 4 & 8 & 9 & 6 & 4 & 6 & 24 & 44 \\
\hline Techniek & 17 & 16 & 7 & 9 & 9 & 14 & 27 \\
\hline Economie & 16 & 16 & 11 & 2 & 8 & 16 & 29 \\
\hline Gezondheidszorg & 1 & 5 & 3 & 1 & 2 & 25 & 64 \\
\hline Gedrag en maatschappij & 2 & 3 & 5 & 6 & 6 & 36 & 42 \\
\hline HBO & 10 & 11 & 11 & 9 & 13 & 18 & 28 \\
\hline Landbouw & 17 & 14 & 9 & 8 & 15 & 14 & 22 \\
\hline Onderwijs & 6 & 23 & 26 & 10 & 15 & 15 & 5 \\
\hline Techniek & 9 & 10 & 11 & 11 & 13 & 15 & 31 \\
\hline Economie & 10 & 9 & 9 & 9 & 13 & 17 & 35 \\
\hline Gezondheidszorg & 22 & 11 & 4 & 4 & 6 & 18 & 35 \\
\hline Gedrag en maatschappij & 3 & 5 & 6 & 10 & 14 & 32 & 30 \\
\hline Taal en cultuur & & & & & 60 & & 40 \\
\hline wo & 8 & 8 & 7 & 7 & 11 & 17 & 43 \\
\hline Landbouw & 6 & 7 & 9 & 6 & 10 & 15 & 48 \\
\hline Techniek & 11 & 9 & 7 & 8 & 8 & 11 & 46 \\
\hline Economie & 4 & 4 & 5 & 7 & 10 & 14 & 56 \\
\hline Gezondheidszorg & 11 & 6 & 3 & 3 & 6 & 18 & 53 \\
\hline Gedrag en maatschappij & 8 & 8 & 8 & 8 & 13 & 22 & 34 \\
\hline Taal en cultuur & 11 & 10 & 10 & 10 & 13 & 18 & 28 \\
\hline Recht en openbare orde & 7 & 10 & 8 & 7 & 14 & 22 & 32 \\
\hline Natuurwetenschappen & 4 & 10 & 7 & 6 & 11 & 13 & 50 \\
\hline Totaal & 14 & 12 & 10 & 8 & 11 & 17 & 28 \\
\hline
\end{tabular}

Toelichting

Het betreft hier de grootte van de totale organisatie (inclusief eventuele andere vestigingen). 
Tabel A8.4

Vereist opleidingsniveau voor de huidige functie volgens de werkgever

\begin{tabular}{|c|c|c|c|}
\hline Opleidingssector & $\begin{array}{r}\text { lager } \\
\%\end{array}$ & $\begin{array}{r}\text { zelfde } \\
\%\end{array}$ & $\begin{array}{r}\text { hoger } \\
\%\end{array}$ \\
\hline VMBO & 15 & 48 & 37 \\
\hline Naar leerweg & & & \\
\hline Theoretisch & 15 & 50 & 35 \\
\hline Gemengd & 17 & 45 & 38 \\
\hline Kaderberoepsgericht & 14 & 47 & 39 \\
\hline Basisberoepsgericht & 16 & 47 & 37 \\
\hline \multicolumn{4}{|l|}{ Naar sector } \\
\hline Landbouw & 16 & 36 & 48 \\
\hline Techniek & 15 & 44 & 42 \\
\hline Economie & 15 & 52 & 33 \\
\hline Gezondheidszorg & 16 & 53 & 32 \\
\hline $\mathrm{BOL}$ & 24 & 66 & 10 \\
\hline BOL niveau 1 & 40 & 47 & 13 \\
\hline BOL niveau 2 & 37 & 42 & 22 \\
\hline Landbouw & 50 & 50 & \\
\hline Techniek & 28 & 48 & 24 \\
\hline Economie & 43 & 35 & 23 \\
\hline Gezondheidszorg & 34 & 47 & 18 \\
\hline BOL niveau 3 & 21 & 77 & 2 \\
\hline Landbouw & 35 & 65 & \\
\hline Techniek & 25 & 75 & \\
\hline Economie & 22 & 73 & 5 \\
\hline Gezondheidszorg & 22 & 78 & 0 \\
\hline Gedrag en maatschappij & 16 & 83 & 1 \\
\hline BoL niveau 4 & 15 & 78 & 6 \\
\hline Landbouw & 24 & 71 & 5 \\
\hline Techniek & 18 & 76 & 6 \\
\hline Economie & 21 & 71 & 8 \\
\hline Gezondheidszorg & 7 & 88 & 5 \\
\hline Gedrag en maatschappij & 9 & 84 & 7 \\
\hline$B B L$ & 32 & 59 & 9 \\
\hline BBL niveau 1 & 54 & 44 & 2 \\
\hline BBL niveau 2 & 36 & 44 & 20 \\
\hline Landbouw & 34 & 53 & 14 \\
\hline Techniek & 35 & 44 & 21 \\
\hline Economie & 45 & 36 & 19 \\
\hline Gezondheidszorg & 25 & 54 & 21 \\
\hline BBL niveau 3 & 32 & 67 & 1 \\
\hline Landbouw & 42 & 56 & 3 \\
\hline Techniek & 47 & 52 & 0 \\
\hline Economie & 39 & 58 & 3 \\
\hline Gezondheidszorg & 17 & 83 & 0 \\
\hline Gedrag en maatschappij & 12 & 88 & \\
\hline BBL niveau 4 & 14 & 81 & 6 \\
\hline Techniek & 18 & 76 & 6 \\
\hline Economie & 33 & 64 & 4 \\
\hline
\end{tabular}


Tabel A8.4

Vereist opleidingsniveau voor de huidige functie volgens de werkgever

Opleidingssecto lager

$\%$
W0

Landbouw

Techniek

Economie

Gezondheidszorg

Gedrag en maatschappij

Taal en cultuur

Recht en openbare orde

Natuurwetenschappen

Totaal

Toelichting

Vraag in de enquête:

Welk opleidingsniveau werd door uw werkgever voor deze functie minimaal vereist? zelfde

$\%$

$\begin{array}{ll}86 & 7 \\ 88 & 6 \\ 83 & 2 \\ 75 & 1 \\ 92 & 1 \\ 89 & 2 \\ 81 & 3 \\ 85 & 1 \\ 72 & 1 \\ 76 & 5\end{array}$

hoger

$\%$

6

2

24

24
7

9

15

14

28

19

36

60

4

30

28

40

15

45

61

21

33

25

63
4
7
2
3
8
2
5
3
7
12

2

3

2

3

7 
Tabel A8.5

Vereiste opleidingsrichting voor de huidige functie volgens de werkgever

\begin{tabular}{|c|c|c|c|}
\hline Opleidingssector & $\begin{array}{r}\text { eigen/verwante } \\
\text { richting } \\
\%\end{array}$ & $\begin{array}{r}\text { andere } \\
\text { richting } \\
\%\end{array}$ & $\begin{array}{r}\text { geen } \\
\text { richting } \\
\%\end{array}$ \\
\hline VMBO & 48 & 3 & 49 \\
\hline Naar leerweg & & & \\
\hline Theoretisch & 39 & 3 & 59 \\
\hline Gemengd & 39 & 13 & 48 \\
\hline Kaderberoepsgericht & 49 & 1 & 49 \\
\hline Basisberoepsgericht & 53 & 3 & 44 \\
\hline \multicolumn{4}{|l|}{ Naar sector } \\
\hline Landbouw & 60 & 4 & 36 \\
\hline Techniek & 58 & 1 & 41 \\
\hline Economie & 44 & 5 & 51 \\
\hline Gezondheidszorg & 43 & 2 & 55 \\
\hline BOL & 65 & 4 & 30 \\
\hline B0L niveau 1 & 37 & 12 & 51 \\
\hline BOL niveau 2 & 50 & 4 & 46 \\
\hline Landbouw & 33 & 5 & 62 \\
\hline Techniek & 59 & 7 & 34 \\
\hline Economie & 45 & 3 & 52 \\
\hline Gezondheidszorg & 52 & 3 & 45 \\
\hline B0L niveau 3 & 73 & 3 & 24 \\
\hline Landbouw & 60 & 8 & 32 \\
\hline Techniek & 83 & 2 & 15 \\
\hline Economie & 62 & 4 & 33 \\
\hline Gezondheidszorg & 76 & 2 & 22 \\
\hline Gedrag en maatschappij & 78 & 3 & 19 \\
\hline BOL niveau 4 & 76 & 3 & 21 \\
\hline Landbouw & 70 & 5 & 25 \\
\hline Techniek & 80 & 2 & 18 \\
\hline Economie & 62 & 6 & 32 \\
\hline Gezondheidszorg & 84 & 2 & 14 \\
\hline Gedrag en maatschappij & 84 & 3 & 13 \\
\hline BBL & 72 & 4 & 24 \\
\hline BBL niveau 1 & 52 & 4 & 44 \\
\hline BBL niveau 2 & 65 & 5 & 30 \\
\hline Landbouw & 59 & 12 & 29 \\
\hline Techniek & 71 & 3 & 26 \\
\hline Economie & 52 & 8 & 41 \\
\hline Gezondheidszorg & 71 & 5 & 24 \\
\hline BBL niveau 3 & 79 & 2 & 18 \\
\hline Landbouw & 69 & 11 & 20 \\
\hline Techniek & 75 & 3 & 22 \\
\hline Economie & 71 & 1 & 28 \\
\hline Gezondheidszorg & 87 & 2 & 11 \\
\hline Gedrag en maatschappij & 86 & 2 & 12 \\
\hline BBL niveau 4 & 84 & 3 & 13 \\
\hline Techniek & 90 & 1 & 9 \\
\hline Economie & 51 & 10 & 39 \\
\hline
\end{tabular}


Tabel A8.5

Vereiste opleidingsrichting voor de huidige functie volgens de werkgever

\begin{tabular}{|c|c|c|c|}
\hline Opleidingssector & $\begin{array}{r}\text { eigen/verwante } \\
\text { richting } \\
\%\end{array}$ & $\begin{array}{r}\text { andere } \\
\text { richting } \\
\%\end{array}$ & $\begin{array}{r}\text { geen } \\
\text { richting } \\
\%\end{array}$ \\
\hline
\end{tabular}

BBL niveau 4 (vervolg)

\section{Gezondheidszorg}

Gedrag en maatschappij

HBO

Landbouw

Onderwijs

Techniek

Economie

Gezondheidszorg

Gedrag en maatschappij

Taal en cultuur

94
89
82
73
94
87
69
93
85
100

W0

Landbouw

Techniek

Economie

Gezondheidszorg

Gedrag en maatschappij

Taal en cultuur

Recht en openbare orde

Natuurwetenschappen

Totaal
1

2

4

6

2

2

5

2

5

\section{5}

20

5

11

26

5

11

Toelichting

Vraag in de enquête:

Welke opleidingsrichting werd door uw werkgever voor deze functie vereist? 
Tabel A8.6

Benutting van kennis en vaardigheden

Opleidingssector

Naar leerweg

Theoretisch

Gemengd

Kaderberoepsgericht

Basisberoepsgericht

Naar sector

Landbouw

Techniek

Economie

Gezondheidszorg

BOL

BOL niveau 1

BOL niveau 2

Landbouw

Techniek

Economie

Gezondheidszorg

BOL niveau 3

Landbouw

68

Techniek

Economie

Gezondheidszorg

Gedrag en maatschappij

BoL niveau 4

Landbouw

Techniek

Economie

Gezondheidszorg

Gedrag en maatschappij

BBL

BBL niveau 1

BBL niveau 2

Techniek

Economie

Gezondheidszor

BBL niveau 3

Techniek

Economie

Gezondheidszorg

BBL niveau 4

Techniek 
Tabel A8.6

Benutting van kennis en vaardigheden

Opleidingssector

HBO

Landbouw

58

Onderwijs

Techniek

Economie

Gezondheidszorg

Gedrag en maatschappij

Taal en cultuur

wO

Landbouw

Techniek

Economie

71

Gezondheidszorg

Gedrag en maatschappi

Taal en cultuur

Recht en openbare orde

48

Natuurwetenschappen

Totaal

Toelichting

Vraag in de enquête:

In welke mate worden in uw huidige functie uw kennis en vaardigheden benut (1 'helemaal niet' tot en met 5 'in sterke mate'). Vermeld is het percentage van antwoordcategorie 4 en 5. 
Tabel A8.7

Kennis en vaardigheden schieten tekort

Opleidingssector

Naarleerweg

Theoretisch

Gemengd

Kaderberoepsgericht

Basisberoepsgericht

Naar sector

Landbouw

Techniek

Economie

Gezondheidszorg

BOL

B0L niveau 1

BOL niveau 2

Landbouw

Techniek

Economie

Gezondheidszorg

BOL niveau 3

Landbouw

Techniek

Economie

Gezondheidszorg

Gedrag en maatschappij

BoL niveau 4

Landbouw

Techniek

Economie

Gezondheidszorg

Gedrag en maatschappij

BBL

BBL niveau 1

BBL niveau 2

Landbouw

Techniek

Economie

Gezondheidszorg

BBL niveau 3

Techniek

Economie

Gezondheidszorg

Gedrag en maatschappij

BBL niveau 4

Techniek

Economie

Gezondheidszorg

Gedrag en maatschappij 
Tabel A8.7

Kennis en vaardigheden schieten tekort

Opleidingssector

HBO

Landbouw

Onderwijs

Techniek

Economie

Gezondheidszorg

Gedrag en maatschappij

Taal en cultuur

WO

Landbouw

Techniek

Economie

Gezondheidszorg

Gedrag en maatschappij

Taal en cultuur

Recht en openbare orde

Natuurwetenschappen

\section{5}

Totaal

Toelichting

Vraag in de enquête:

In welke mate schieten uw kennis en vaardigheden tekort voor uw huidige functie (1 'helemaal niet' tot en met 5 'in sterke mate')? Vermeld is het percentage van antwoordcategorie 4 en 5. 
Tabel A8.8

Oordeel van de werkende schoolverlaters over de aansluiting tussen de afgesloten opleiding en de huidige functie

\begin{tabular}{|c|c|c|c|c|}
\hline Opleidingssector & $\begin{array}{r}\text { goed } \\
\%\end{array}$ & $\begin{array}{r}\text { voldoende } \\
\%\end{array}$ & $\begin{array}{r}\text { matig } \\
\%\end{array}$ & $\begin{array}{r}\text { slecht } \\
\%\end{array}$ \\
\hline $\begin{array}{l}\text { VMBO } \\
\text { Naar leerweg }\end{array}$ & 28 & 42 & 19 & 11 \\
\hline Theoretisch & 24 & 40 & 22 & 14 \\
\hline Gemengd & 21 & 38 & 37 & 4 \\
\hline Kaderberoepsgericht & 26 & 44 & 17 & 13 \\
\hline Basisberoepsgericht & 33 & 42 & 17 & 9 \\
\hline Naar sector & & & & \\
\hline Landbouw & 27 & 42 & 21 & 10 \\
\hline Techniek & 33 & 45 & 16 & 7 \\
\hline Economie & 28 & 33 & 20 & 19 \\
\hline Gezondheidszorg & 26 & 48 & 18 & 8 \\
\hline BOL & 28 & 47 & 16 & 9 \\
\hline BoL niveau 1 & 28 & 51 & 11 & 10 \\
\hline BoL niveau 2 & 28 & 44 & 15 & 13 \\
\hline Landbouw & 20 & 40 & 25 & 15 \\
\hline Techniek & 24 & 44 & 18 & 14 \\
\hline Economie & 30 & 49 & 11 & 10 \\
\hline Gezondheidszorg & 33 & 34 & 16 & 17 \\
\hline BOL niveau 3 & 31 & 47 & 15 & 8 \\
\hline Landbouw & 25 & 53 & 12 & 10 \\
\hline Techniek & 25 & 53 & 18 & 4 \\
\hline Economie & 25 & 46 & 20 & 9 \\
\hline Gezondheidszorg & 31 & 50 & 12 & 6 \\
\hline Gedrag en maatschappij & 37 & 42 & 13 & 8 \\
\hline BoL niveau 4 & 26 & 48 & 18 & 8 \\
\hline Landbouw & 28 & 44 & 17 & 11 \\
\hline Techniek & 25 & 50 & 18 & 8 \\
\hline Economie & 24 & 46 & 20 & 9 \\
\hline Gezondheidszorg & 29 & 46 & 18 & 7 \\
\hline Gedrag en maatschappij & 27 & 50 & 17 & 7 \\
\hline BBL & 37 & 46 & 12 & 5 \\
\hline BBL niveau 1 & 37 & 45 & 9 & 9 \\
\hline BBL niveau 2 & 35 & 46 & 13 & 6 \\
\hline Landbouw & 29 & 48 & 14 & 9 \\
\hline Techniek & 33 & 49 & 12 & 6 \\
\hline Economie & 31 & 44 & 18 & 7 \\
\hline Gezondheidszorg & 49 & 40 & 6 & 5 \\
\hline BBL niveau 3 & 43 & 44 & 10 & 3 \\
\hline Landbouw & 53 & 24 & 12 & 12 \\
\hline Techniek & 34 & 48 & 13 & 6 \\
\hline Economie & 43 & 41 & 14 & 2 \\
\hline Gezondheidszorg & 49 & 44 & 7 & \\
\hline Gedrag en maatschappij & 53 & 38 & 7 & 2 \\
\hline
\end{tabular}


Tabel A8.8

Oordeel van de werkende schoolverlaters over de aansluiting tussen de afgesloten opleiding en de huidige functie

$\begin{array}{lrrrr} & & & \text { matig } & \text { soldoende } \\ \text { Opleidingssector } & \text { goed } & \% & \% & \%\end{array}$

\begin{tabular}{|c|c|c|c|c|}
\hline BBL niveau 4 & 29 & 49 & 17 & 5 \\
\hline Techniek & 28 & 59 & 9 & 5 \\
\hline Economie & 29 & 38 & 21 & 12 \\
\hline Gezondheidszorg & 31 & 48 & 18 & 3 \\
\hline Gedrag en maatschappij & 28 & 50 & 18 & 4 \\
\hline HBO & 31 & 47 & 17 & 5 \\
\hline Landbouw & 31 & 44 & 16 & 9 \\
\hline Onderwijs & 39 & 46 & 11 & 4 \\
\hline Techniek & 28 & 49 & 20 & 4 \\
\hline Economie & 26 & 48 & 20 & 5 \\
\hline Gezondheidszorg & 36 & 46 & 14 & 4 \\
\hline Gedrag en maatschappij & 31 & 45 & 18 & 6 \\
\hline Taal en cultuur & 43 & 34 & 13 & 10 \\
\hline W0 & 37 & 41 & 16 & 6 \\
\hline Landbouw & 42 & 40 & 13 & 5 \\
\hline Techniek & 43 & 42 & 12 & 2 \\
\hline Economie & 37 & 46 & 14 & 3 \\
\hline Gezondheidszorg & 54 & 35 & 8 & 3 \\
\hline Gedrag en maatschappij & 28 & 42 & 22 & 9 \\
\hline Taal en cultuur & 23 & 35 & 24 & 18 \\
\hline Recht en openbare orde & 36 & 45 & 15 & 5 \\
\hline Natuurwetenschappen & 45 & 37 & 12 & 5 \\
\hline Totaal & 32 & 45 & 16 & 7 \\
\hline
\end{tabular}

Toelichting

Vraag in de enquête:

Hoe vindt $u$ de aansluiting tussen uw [...] opleiding en uw huidige functie? 
Tabel A8.9

Tevredenheid met huidige functie

Opleidingssector

Naarleerweg

Theoretisch

Gemengd

Kaderberoepsgericht

Basisberoepsgericht

Naar sector

Landbouw

Techniek

Economie

Gezondheidszorg

BOL

BOL niveau 1

BOL niveau 2

Landbouw

Techniek

Economie

Gezondheidszorg

B0L niveau 3

Landbouw

Techniek

69

Economie

Gezondheidszorg

Gedrag en maatschappi

BOL niveau 4

Landbouw

69

Techniek

Economie

Gezondheidszorg

Gedrag en maatschappij

BBL

BBL niveau 1

BBL niveau 2

Techniek

Economie

Gezondheidszorg

BBL niveau 3

Landbouw

Techniek

Economie

Gezondheidszorg

BBL niveau 4

Techniek

Gezondheidszorg 
Tabel A8.9

Tevredenheid met huidige functie

Opleidingssector

HBO

Landbouw

Onderwijs

65

Techniek

Economie

Gezondheidszorg

Gedrag en maatschappij

Taal en cultuur

WO 70

Landbouw

Techniek 76

Economie

Gezondheidszorg

Gedrag en maatschappij

Taal en cultuur 57

Recht en openbare orde

Natuurwetenschappen

Totaal

Toelichting

Vraag in de enquête:

Hoe tevreden bent u met uw huidige functie ( 1 'zeer ontevreden' tot en met 5 'zeer tevreden'. Vermeld is het percentage van antwoordcategorie 4 en 5. 
Tabel A9.1

Werkloosheid

aanbieden op arbeidsmarkt

HAVO

VW0

VMBO

Naar leerweg

Theoretisch

Gemengd

Kaderberoepsgericht

Basisberoepsgericht

Naar sector

Landbouw

Techniek

Economie

Gezondheidszorg

BOL

BOL niveau 1

BOL niveau 2

Landbouw

Techniek

Economie

Gezondheidszorg

BOL niveau 3

Landbouw

Techniek

Economie

Gezondheidszorg

Gedrag en maatschappij

B0L niveau 4

Landbouw

Techniek

Economie

Gezondheidszorg

Gedrag en maatschappi

BBL

BBL niveau 1

BBL niveau 2

Landbouw

Techniek

Economie

Gezondheidszorg

BBL niveau 3

Landbouw

Techniek

Economie

Gezondheidszorg

Gedrag en maatschappij

(2)

werkloosheid

$\begin{array}{ll}80 & 4 \\ 89 & 1 \\ 86 & 0 \\ 66 & 0 \\ 88 & 4 \\ 84 & 4 \\ & 6\end{array}$

$\begin{array}{ll}97 & 0 \\ 97 & 0 \\ 99 & 0 \\ 95 & 1 \\ 97 & 0 \\ 98 & 3\end{array}$


Tabel A9.1

Werkloosheid

BBL niveau 4

$\begin{array}{rr}97 & 2 \\ 100 & 6 \\ 93 & 0 \\ 98 & 0 \\ 98 & 2\end{array}$

Techniek

Economie

Gezondheidszorg

Gedrag en maatschappij

$\begin{array}{ll}82 & 3 \\ 82 & 3 \\ 89 & 3 \\ 80 & 4 \\ 76 & 2 \\ 91 & 4 \\ 85 & 2 \\ 87 & 4 \\ & 7\end{array}$

HBO

Landbouw

Onderwijs

Techniek

Economie

Gezondheidszorg

Gedrag en maatschappij

Taal en cultuur

W0

$93 \quad 3$

Landbouw

Techniek

Economie

Gezondheidszorg

Gedrag en maatschappij

Taal en cultuur

Recht en openbare orde

Natuurwetenschappen

Totaal

92
97

$96 \quad 2$

$88-3$

$\begin{array}{ll}93 & 4 \\ 89 & 6\end{array}$

89

95

92

56

4

Toelichting

Het werkloosheidspercentage heeft betrekking op de werkloze beroepsbevolking: schoolverlaters zonder werk (of met werk van minder dan 12 uur per week) die op zoek zijn naar betaald werk. Daarbij is tevens als voorwaarde gesteld dat de maatschappelijke positie niet scholier of student is. 
Tabel A9.2

Werkloosheid tot eerste baan

Opleidingssector

$$
\begin{array}{rrrrr}
0 \text { mnd. } & 1-3 \text { mnd. } & 4-6 \text { mnd. } & 7-12 \text { mnd. } & \geq 13 \text { mnd. } \\
\% & \% & \% & \% & \%
\end{array}
$$

VMBO

Naarleerweg

Theoretisch

Gemengd

Kaderberoepsgericht

Basisberoepsgericht

Naar sector

Landbouw

Techniek

Economie

Gezondheidszorg

BOL

BOL niveau 1

BOL niveau 2

Landbouw

Techniek

Economie

Gezondheidszorg

BOL niveau 3

Landbouw

Techniek

Economie

Gezondheidszorg

Gedrag en maatschappij

$\begin{array}{ll}88 & 7 \\ 90 & 5 \\ 90 & 2 \\ 88 & 8 \\ 88 & 7\end{array}$

$\begin{array}{ll}2 & 2 \\ 3 & 3 \\ 3 & 5 \\ 2 & 1 \\ 2 & 3\end{array}$

BOL niveau 4

Landbouw

Techniek

Economie

Gezondheidszorg

Gedrag en maatschappij

BBL

BBL niveau 1

BBL niveau 2

Landbouw

Techniek

Economie

Gezondheidszorg

90
94
80
84

87

76

$82 \quad 8$

81

81

84

79

88
91
96
85
93
85

90
88
90
88
94
92

95

92

95

95
97

95

93

96

BBL niveau 3

Landbouw

Techniek

Economie

Gezondheidszorg

Gedrag en maatschappi

96
97
95
93
100
88

maanden

\section{0}

0,5

$\begin{array}{cc}\% & \text { maanden } \\ 0 & 0,5 \\ 0 & \\ 0 & 0,5 \\ 1 & 0,6 \\ 0 & 0,6 \\ & 0,6\end{array}$

0,6

0,3

0,3

0,8

0,9

0,8

1,9

1,2

0,5

1,3

0,9

1,9

0,6

0,5

0,2

0,8

0,2

0,9

0,4

0,5

0,4

0,6

0,3

0,4

0,3

0,7

0,3

0,1

0,2

0,4

0,3

0,3

0,2

0,2

0,7

0,0

0,0
0,8 
Tabel A9.2

Werkloosheid tot eerste baan

\begin{tabular}{|c|c|c|c|c|c|c|}
\hline Opleidingssector & $\begin{array}{r}0 \text { mnd. } \\
\%\end{array}$ & $\begin{array}{r}1-3 \text { mnd. } \\
\%\end{array}$ & $\begin{array}{r}4-6 \text { mnd. } \\
\%\end{array}$ & $\begin{array}{r}7-12 \text { mnd. } \\
\%\end{array}$ & $\begin{array}{r}\geq 13 \text { mnd. } \\
\%\end{array}$ & maanden \\
\hline BBL niveau 4 & 97 & 2 & 1 & 0 & 0 & 0,1 \\
\hline Techniek & 99 & 1 & 0 & 0 & 0 & 0,0 \\
\hline Economie & 98 & 1 & 0 & 1 & 0 & 0,1 \\
\hline Gezondheidszorg & 96 & 2 & 1 & 0 & 0 & 0,1 \\
\hline Gedrag en maatschappij & 97 & 2 & 2 & 0 & 0 & 0,1 \\
\hline HBO & 75 & 17 & 5 & 2 & 1 & 0,9 \\
\hline Landbouw & 70 & 23 & 5 & 2 & 0 & 0,9 \\
\hline Onderwijs & 77 & 15 & 4 & 2 & 2 & 1,0 \\
\hline Techniek & 76 & 16 & 5 & 2 & 0 & 0,8 \\
\hline Economie & 74 & 18 & 6 & 2 & 0 & 0,9 \\
\hline Gezondheidszorg & 79 & 14 & 5 & 1 & 1 & 0,8 \\
\hline Gedrag en maatschappij & 72 & 18 & 6 & 4 & 1 & 1,1 \\
\hline Taal en cultuur & 77 & 13 & 7 & 3 & 0 & 1,1 \\
\hline wo & 69 & 19 & 8 & 4 & 1 & 1,3 \\
\hline Landbouw & 61 & 24 & 9 & 5 & 1 & 1,6 \\
\hline Techniek & 64 & 23 & 9 & 4 & 0 & 1,3 \\
\hline Economie & 71 & 17 & 10 & 2 & 0 & 1,0 \\
\hline Gezondheidszorg & 71 & 22 & 5 & 2 & 1 & 1,0 \\
\hline Gedrag en maatschappij & 69 & 17 & 8 & 5 & 1 & 1,4 \\
\hline Taal en cultuur & 69 & 17 & 8 & 5 & 1 & 1,4 \\
\hline Recht en openbare orde & 69 & 17 & 9 & 4 & 0 & 1,2 \\
\hline Natuurwetenschappen & 74 & 16 & 6 & 3 & 1 & 1,1 \\
\hline Totaal & 84 & 10 & 4 & 2 & 1 & 0,7 \\
\hline
\end{tabular}


Tabel A9.3

Percentage werkende schoolverlaters dat op zoek is naar een andere baan

Opleidingssector

HAVO/VWO

HAVO

VWO

VMBO

leerweg

Theoretisch

Kaderberoepsgericht

Basisberoepsgericht

Naar sector

Landbouw

Techniek

Economie

Gezondheidszorg

BOL

B0L niveau 1

BOL niveau 2

Landbouw

Techniek

Economie

Gezondheidszorg

BOL niveau 3

Techniek

Economie

Gezondheidszorg

Gedrag en maatschappi

BOL niveau 4

Landbouw

Techniek

Economie

Gezondheidszorg

Gedrag en maatschappij

BBL

BBL niveau 2

Techniek

Economie

Gezondheidszorg

BBL niveau 3

Techniek

Economie

Gezondheidszorg 
Tabel A9.3

Percentage werkende schoolverlaters dat op zoek is naar een andere baan

Opleidingssector

BBL niveau 4

Techniek

Economie

11

Gezondheidszorg

12

Gedrag en maatschappij

HBO

Landbouw

Onderwijs

17

Techniek

Economie

Gezondheidszorg

Gedrag en maatschappij

Taal en cultuur

Wo 20

Landbouw

Techniek

Economie

Gezondheidszorg

Gedrag en maatschappij

Taal en cultuur

Recht en openbare orde

Natuurwetenschappen 
Tabel A9.4

Aard van het dienstverband van werkende schoolverlaters

\begin{tabular}{|c|c|c|c|c|c|}
\hline Opleidingssector & $\begin{array}{r}\text { leer/werk- } \\
\text { overeenkomst } \\
\%\end{array}$ & $\begin{array}{r}\text { uitzend-, } \\
\text { oproepkracht } \\
\%\end{array}$ & $\begin{array}{r}\text { loondienst } \\
\text { werkgever } \\
\%\end{array}$ & $\begin{array}{r}\text { bedrijf ouders/ } \\
\text { partner } \\
\%\end{array}$ & $\begin{array}{r}\text { eigen bedrijf/free- } \\
\text { lance } \\
\%\end{array}$ \\
\hline HAVO/VWO & 18 & 18 & 61 & 3 & 0 \\
\hline HAVO & 23 & 21 & 54 & 2 & 0 \\
\hline VW0 & 6 & 11 & 78 & 5 & 0 \\
\hline VMBO & 38 & 8 & 51 & 1 & 1 \\
\hline Naar leerweg & & & & & \\
\hline Theoretisch & 32 & 12 & 54 & 1 & 1 \\
\hline Gemengd & 33 & 12 & 51 & 0 & 4 \\
\hline Kaderberoepsgericht & 42 & 6 & 50 & 0 & 1 \\
\hline Basisberoepsgericht & 39 & 8 & 50 & 1 & 1 \\
\hline Naar sector & & & & & \\
\hline Landbouw & 36 & 9 & 52 & 1 & 2 \\
\hline Techniek & 50 & 4 & 43 & 1 & 1 \\
\hline Economie & 30 & 13 & 56 & 0 & 1 \\
\hline Gezondheidszorg & 35 & 6 & 57 & 1 & 1 \\
\hline $\mathrm{BOL}$ & 7 & 9 & 81 & 1 & 2 \\
\hline BOL niveau 1 & 12 & 20 & 64 & 1 & 2 \\
\hline BOL niveau 2 & 12 & 11 & 73 & 2 & 2 \\
\hline Landbouw & 20 & 5 & 65 & 10 & 0 \\
\hline Techniek & 18 & 16 & 61 & 2 & 3 \\
\hline Economie & 10 & 10 & 76 & 2 & 2 \\
\hline Gezondheidszorg & 9 & 6 & 83 & 0 & 1 \\
\hline BOL niveau 3 & 4 & 7 & 86 & 0 & 2 \\
\hline Landbouw & 4 & 6 & 80 & 1 & 9 \\
\hline Techniek & 3 & 5 & 86 & 0 & 7 \\
\hline Economie & 4 & 11 & 83 & 1 & 1 \\
\hline Gezondheidszorg & 6 & 6 & 86 & 0 & 2 \\
\hline Gedrag en maatschappij & 3 & 6 & 90 & 0 & 1 \\
\hline BOL niveau 4 & 4 & 6 & 88 & 1 & 1 \\
\hline Landbouw & 4 & 8 & 79 & 6 & 3 \\
\hline Techniek & 3 & 4 & 89 & 1 & 3 \\
\hline Economie & 4 & 8 & 85 & 1 & 2 \\
\hline Gezondheidszorg & 6 & 6 & 88 & 0 & 0 \\
\hline Gedrag en maatschappij & 4 & 5 & 91 & 0 & 0 \\
\hline BBL & 12 & 2 & 84 & 1 & 1 \\
\hline BBL niveau 1 & 6 & 2 & 92 & 0 & 0 \\
\hline BBL niveau 2 & 13 & 4 & 81 & 1 & 1 \\
\hline Landbouw & 11 & 4 & 86 & 0 & 0 \\
\hline Techniek & 15 & 4 & 77 & 3 & 1 \\
\hline Economie & 7 & 3 & 91 & 0 & 0 \\
\hline Gezondheidszorg & 19 & 3 & 76 & 0 & 1 \\
\hline BBL niveau 3 & 11 & 2 & 85 & 0 & 2 \\
\hline Landbouw & 3 & 3 & 86 & 0 & 8 \\
\hline Techniek & 6 & 2 & 88 & 1 & 3 \\
\hline Economie & 9 & 0 & 90 & 0 & 1 \\
\hline Gezondheidszorg & 18 & 1 & 80 & 0 & 2 \\
\hline Gedrag en maatschappij & 7 & 5 & 87 & 0 & 2 \\
\hline
\end{tabular}


Tabel A9.4

Aard van het dienstverband van werkende schoolverlaters

\begin{tabular}{|c|c|c|c|c|c|}
\hline Opleidingssector & $\begin{array}{r}\text { leer/werk- } \\
\text { overeenkomst } \\
\%\end{array}$ & $\begin{array}{r}\text { uitzend-, } \\
\text { oproepkracht } \\
\%\end{array}$ & $\begin{array}{r}\text { loondienst } \\
\text { werkgever } \\
\%\end{array}$ & $\begin{array}{r}\text { bedrijf ouders/ } \\
\text { partner } \\
\%\end{array}$ & $\begin{array}{r}\text { eigen bedriif/free- } \\
\text { lance } \\
\%\end{array}$ \\
\hline BBL niveau 4 & 13 & 1 & 83 & 2 & 1 \\
\hline Techniek & 3 & 0 & 88 & 7 & 2 \\
\hline Economie & 11 & 4 & 82 & 4 & 0 \\
\hline Gezondheidszorg & 22 & 2 & 76 & 0 & 0 \\
\hline Gedrag en maatschappij & 10 & 0 & 88 & 0 & 2 \\
\hline HBO & 0 & 5 & 89 & 1 & 6 \\
\hline Landbouw & 0 & 10 & 82 & 3 & 6 \\
\hline Onderwijs & 0 & 8 & 91 & 0 & 1 \\
\hline Techniek & 0 & 3 & 94 & 1 & 3 \\
\hline Economie & 0 & 4 & 92 & 1 & 3 \\
\hline Gezondheidszorg & 0 & 3 & 93 & 0 & 4 \\
\hline Gedrag en maatschappij & 0 & 5 & 93 & 0 & 1 \\
\hline Taal en cultuur & 0 & 3 & 45 & 0 & 52 \\
\hline WO & 0 & 3 & 93 & 0 & 3 \\
\hline Landbouw & 0 & 5 & 93 & 1 & 2 \\
\hline Techniek & 0 & 1 & 95 & 0 & 4 \\
\hline Economie & 0 & 1 & 97 & 0 & 2 \\
\hline Gezondheidszorg & 0 & 2 & 91 & 0 & 6 \\
\hline Gedrag en maatschappij & 0 & 5 & 93 & 0 & 2 \\
\hline Taal en cultuur & 0 & 8 & 86 & 0 & 6 \\
\hline Recht en openbare orde & 0 & 2 & 96 & 0 & 2 \\
\hline Natuurwetenschappen & 0 & 2 & 97 & 0 & 1 \\
\hline Totaal & 10 & 6 & 81 & 1 & 3 \\
\hline
\end{tabular}


Tabel A9.5

Percentage werkende schoolverlaters met een flexibele aanstelling

Opleidingssector

HAVO/VWO

HAVO

VWO

VMBO

Naar leerweg

Theoretisch

Gemengd

Kaderberoepsgericht

Basisberoepsgericht

Naar sector

Landbouw

Techniek

Economie

Gezondheidszorg

BOL

B0L niveau 1

72

BOL niveau 2

Landbouw

Techniek

Economie

Gezondheidszorg

BOL niveau 3

Landbouw

Techniek

40

Economie

Gezondheidszorg

Gedrag en maatschappi

BOL niveau 4

Landbouw

Techniek

Economie

Gezondheidszorg

42

Gedrag en maatschappij

BBL

BBL niveau 1

BBL niveau 2

Techniek

Economie

Gezondheidszorg

BBL niveau 3

Techniek

Economie

Gezondheidszorg 
Tabel A9.5

Percentage werkende schoolverlaters met een flexibele aanstelling

Opleidingssector

BBL niveau 4

Techniek

Economie

12

Gezondheidszorg

Gedrag en maatschappij

HBO

Landbouw

Onderwijs

Techniek

Economie

Gezondheidszorg

Gedrag en maatschappij

Taal en cultuur

Wo

Landbou

Techniek

Economie

Gezondheidszorg

51

Gedrag en maatschappij

Taal en cultuur

Recht en openbare orde

Natuurwetenschappen

Totaal

Toelichting

Een flexibele aanstelling betreft een aanstelling als uitzendkracht, oproepkracht e.d. of een aanstelling in tijdelijke dienst. 
Tabel A9.6

Beloning van werkende schoolverlaters

\begin{tabular}{|c|c|c|}
\hline Opleidingssector & $\begin{array}{r}\text { gemiddeld } \\
\text { bruto maandloon }\end{array}$ & $\begin{array}{r}\text { gemiddeld } \\
\text { bruto uurloon }\end{array}$ \\
\hline & $€$ & $€$ \\
\hline HAVO/VWO & 729 & 6,42 \\
\hline HAVO & 724 & 6,30 \\
\hline VWo & 743 & 6,78 \\
\hline $\begin{array}{l}\text { VMBO } \\
\text { Naarleerweg }\end{array}$ & 678 & 4,83 \\
\hline Theoretisch & 651 & 4,73 \\
\hline Gemengd & 684 & 4,90 \\
\hline Kaderberoepsgericht & 693 & 4,90 \\
\hline Basisberoepsgericht & 682 & 4,82 \\
\hline Naar sector & & \\
\hline Landbouw & 653 & 4,66 \\
\hline Techniek & 797 & 5,21 \\
\hline Economie & 633 & 4,75 \\
\hline Gezondheidszorg & 561 & 4,42 \\
\hline $\mathrm{BOL}$ & 1.305 & 9,10 \\
\hline BoL niveau 1 & 1.102 & 7,84 \\
\hline BOL niveau 2 & 1.110 & 7,57 \\
\hline Landbouw & 901 & 6,08 \\
\hline Techniek & 1.229 & 7,64 \\
\hline Economie & 1.150 & 7,70 \\
\hline Gezondheidszorg & 908 & 7,40 \\
\hline BOL niveau 3 & 1.299 & 9,43 \\
\hline Landbouw & 1.230 & 7,86 \\
\hline Techniek & 1.823 & 10,92 \\
\hline Economie & 1.387 & 8,83 \\
\hline Gezondheidszorg & 1.186 & 9,41 \\
\hline Gedrag en maatschappij & 1.201 & 9,82 \\
\hline BoL niveau 4 & 1.462 & 10,06 \\
\hline Landbouw & 1.223 & 8,10 \\
\hline Techniek & 1.715 & 10,49 \\
\hline Economie & 1.409 & 9,22 \\
\hline Gezondheidszorg & 1.445 & 10,82 \\
\hline Gedrag en maatschappij & 1.304 & 10,46 \\
\hline BBL & 1.573 & 10,81 \\
\hline BBL niveau 1 & 1.284 & 9,00 \\
\hline BBL niveau 2 & 1.471 & 9,82 \\
\hline Landbouw & 1.572 & 9,73 \\
\hline Techniek & 1.574 & 9,48 \\
\hline Economie & 1.437 & 9,89 \\
\hline Gezondheidszorg & 1.197 & 10,73 \\
\hline BBL niveau 3 & 1.630 & 11,40 \\
\hline Landbouw & 1.793 & 11,26 \\
\hline Techniek & 1.922 & 11,62 \\
\hline Economie & 1.423 & 9,43 \\
\hline Gezondheidszorg & 1.444 & 12,00 \\
\hline Gedrag en maatschappij & 1.401 & 11,64 \\
\hline
\end{tabular}


Tabel A9.6

Beloning van werkende schoolverlaters

$\begin{array}{rr}\text { Opleidingsector } & \begin{array}{r}\text { gemiddeld } \\ \text { bruto maandloon } \\ \text { gemiddeld } \\ \text { bruto uurloon } \\ €\end{array}\end{array}$

\begin{tabular}{|c|c|c|}
\hline BBL niveau 4 & 1.814 & 12,63 \\
\hline Techniek & 2.165 & 13,32 \\
\hline Economie & 1.602 & 10,20 \\
\hline Gezondheidszorg & 1.755 & 13,03 \\
\hline Gedrag en maatschappij & 1.749 & 13,07 \\
\hline HBO & 1.990 & 13,06 \\
\hline Landbouw & 1.982 & 12,21 \\
\hline Onderwijs & 1.827 & 12,74 \\
\hline Techniek & 2.259 & 13,59 \\
\hline Economie & 2.139 & 13,19 \\
\hline Gezondheidszorg & 1.920 & 14,75 \\
\hline Gedrag en maatschappij & 1.775 & 12,73 \\
\hline Taal en cultuur & 1.363 & 10,14 \\
\hline W0 & 2.479 & 15,58 \\
\hline Landbouw & 2.172 & 13,93 \\
\hline Techniek & 2.612 & 15,51 \\
\hline Economie & 2.845 & 16,88 \\
\hline Gezondheidszorg & 2.722 & 16,82 \\
\hline Gedrag en maatschappij & 2.283 & 15,41 \\
\hline Taal en cultuur & 2.007 & 13,85 \\
\hline Recht en openbare orde & 2.585 & 15,68 \\
\hline Natuurwetenschappen & 2.389 & 14,39 \\
\hline Totaal & 1.596 & 10,69 \\
\hline
\end{tabular}

Toelichting

Dit betreft het bruto inkomen in de hoofdfunctie. Dit is inclusief toeslagen maar exclusief inkomen uit overwerk. Er is hier niet gecorrigeerd voor verschillen in leeftijd van de schoolverlaters. 
Tabel A9.7

Percentage werkende schoolverlaters met een deeltijdaanstelling en wekelijkse arbeidsduur

\begin{tabular}{|c|c|c|}
\hline Opleidingssector & $\begin{array}{r}\text { deeltijdaanstelling } \\
\%\end{array}$ & $\begin{array}{l}\text { wekelijkse } \\
\text { arbeidsduur uren }\end{array}$ \\
\hline HAVO/VWO & 60 & 27,1 \\
\hline HAVO & 62 & 26,8 \\
\hline VW0 & 54 & 27,8 \\
\hline VMBO & 53 & 31,9 \\
\hline Naarleerweg & & \\
\hline Theoretisch & 54 & 30,2 \\
\hline Gemengd & 61 & 31,1 \\
\hline Kaderberoepsgericht & 52 & 32,6 \\
\hline Basisberoepsgericht & 51 & 32,5 \\
\hline Naar sector & & \\
\hline Landbouw & 60 & 31,4 \\
\hline Techniek & 41 & 35,1 \\
\hline Economie & 54 & 31,2 \\
\hline Gezondheidszorg & 67 & 29,6 \\
\hline BOL & 41 & 33,4 \\
\hline BoL niveau 1 & 37 & 33,2 \\
\hline BOL niveau 2 & 36 & 33,8 \\
\hline Landbouw & 48 & 33,0 \\
\hline Techniek & 18 & 37,2 \\
\hline Economie & 33 & 34,3 \\
\hline Gezondheidszorg & 64 & 28,9 \\
\hline B0L niveau 3 & 50 & 32,3 \\
\hline Landbouw & 23 & 36,4 \\
\hline Techniek & 4 & 40,4 \\
\hline Economie & 23 & 36,2 \\
\hline Gezondheidszorg & 70 & 29,9 \\
\hline Gedrag en maatschappij & 70 & 28,6 \\
\hline BOL niveau 4 & 40 & 33,7 \\
\hline Landbouw & 32 & 35,5 \\
\hline Techniek & 15 & 37,9 \\
\hline Economie & 27 & 35,2 \\
\hline Gezondheidszorg & 54 & 31,2 \\
\hline Gedrag en maatschappij & 72 & 29,1 \\
\hline BBL & 37 & 33,8 \\
\hline BBL niveau 1 & 37 & 33,0 \\
\hline BBL niveau 2 & 31 & 34,7 \\
\hline Landbouw & 15 & 37,1 \\
\hline Techniek & 6 & 38,6 \\
\hline Economie & 38 & 33,3 \\
\hline Gezondheidszorg & 88 & 25,9 \\
\hline BBL niveau 3 & 41 & 33,3 \\
\hline Landbouw & 8 & 36,8 \\
\hline Techniek & 5 & 38,6 \\
\hline Economie & 30 & 34,6 \\
\hline Gezondheidszorg & 78 & 28,0 \\
\hline Gedrag en maatschappij & 81 & 28,2 \\
\hline
\end{tabular}


Tabel A9.7

Percentage werkende schoolverlaters met een deeltijdaanstelling en wekelijkse arbeidsduur

\begin{tabular}{|c|c|c|}
\hline Opleidingssector & $\begin{array}{r}\text { deeltijdaanstelling } \\
\%\end{array}$ & $\begin{array}{l}\text { wekelijkse } \\
\text { arbeidsduur uren }\end{array}$ \\
\hline BBL niveau 4 & 44 & 33,3 \\
\hline Techniek & 15 & 37,4 \\
\hline Economie & 22 & 35,8 \\
\hline Gezondheidszorg & 59 & 31,4 \\
\hline Gedrag en maatschappij & 61 & 30,9 \\
\hline HBO & 27 & 36,6 \\
\hline Landbouw & 17 & 38,4 \\
\hline Onderwijs & 39 & 34,7 \\
\hline Techniek & 6 & 39,3 \\
\hline Economie & 12 & 38,2 \\
\hline Gezondheidszorg & 58 & 32,3 \\
\hline Gedrag en maatschappij & 54 & 33,2 \\
\hline Taal en cultuur & 49 & 37,4 \\
\hline wo & 20 & 37,3 \\
\hline Landbouw & 14 & 37,7 \\
\hline Techniek & 6 & 39,4 \\
\hline Economie & 4 & 39,0 \\
\hline Gezondheidszorg & 20 & 37,6 \\
\hline Gedrag en maatschappij & 37 & 35,3 \\
\hline Taal en cultuur & 38 & 35,2 \\
\hline Recht en openbare orde & 10 & 38,2 \\
\hline Natuurwetenschappen & 10 & 38,3 \\
\hline Totaal & 36 & 34,4 \\
\hline
\end{tabular}

Toelichting

De arbeidsduur betreft zowel het aantal uren in de hoofdfunctie als het aantal uren in eventuele nevenfuncties (HBO en WO).

Een deeltijdaanstelling is een aanstelling met minder dan 33 arbeidsuren per week. 
Tabel A9.8

Percentage werkende schoolverlaters waarvan huidige functie goede carrièremogelijkheden biedt

Opleidingssector

VMBO

Naar leerweg

Theoretisch

Gemengd

Kaderberoepsgericht

Basisberoepsgericht

Naar sector

Landbouw

Techniek

Economie

Gezondheidszorg

BOI

BOL niveau 1

BOL niveau 2

Landbouw

Techniek

Economie

Gezondheidszorg

BOL niveau 3

Landbouw

Techniek

Economie

Gezondheidszorg

Gedrag en maatschappi

BOL niveau 4

Landbouw

Techniek

Economie

Gezondheidszorg

Gedrag en maatschappij

BBL

BBL niveau 1

BBL niveau 2

Techniek

57

Economie

Gezondheidszorg

BBL niveau 3

Techniek

Economie

Gezondheidszorg

42

Gedrag en maatschappij

BBL niveau 4

Techniek 
Tabel A9.8

Percentage werkende schoolverlaters waarvan huidige functie goede carrièremogelijkheden biedt

Opleidingssector

HBO

Landbouw

Onderwijs

Techniek

Economie

Gezondheidszorg

Gedrag en maatschappij

Taal en cultuur

WO

Landbouw

Techniek

Economie

Gezondheidszorg

Gedrag en maatschappij

Taal en cultuur

Recht en openbare orde

Natuurwetenschappen

Totaal

Toelichting

Vraag in de enquête:

Biedt uw functie goede carrièremogelijkheden? (1 'nauwelijks' tot en met 5 'heel veel'). Vermeld is het percentage van antwoordcategorie 4 en 5. 
Tabel A10.1

Opleiding achteraf opnieuw kiezen: intrede op de arbeidsmarkt

\begin{tabular}{|c|c|c|c|}
\hline Opleidingssector & $\begin{array}{r}\text { zelfde } \\
\text { opleiding } \\
\%\end{array}$ & $\begin{array}{r}\text { andere } \\
\text { opleiding } \\
\%\end{array}$ & $\begin{array}{r}\text { geen } \\
\text { opleiding } \\
\%\end{array}$ \\
\hline VMBO & 80 & 20 & 0 \\
\hline Naar leerweg & & & \\
\hline Theoretisch & 83 & 17 & 0 \\
\hline Gemengd & 89 & 11 & 0 \\
\hline Kaderberoepsgericht & 78 & 22 & 0 \\
\hline Basisberoepsgericht & 78 & 22 & 0 \\
\hline \multicolumn{4}{|l|}{ Naar sector } \\
\hline Landbouw & 72 & 28 & 0 \\
\hline Techniek & 78 & 22 & 0 \\
\hline Economie & 79 & 21 & 0 \\
\hline Gezondheidszorg & 83 & 17 & 0 \\
\hline BOL & 73 & 21 & 5 \\
\hline BOL niveau 1 & 66 & 25 & 8 \\
\hline BOL niveau 2 & 63 & 27 & 10 \\
\hline Landbouw & 80 & 20 & 0 \\
\hline Techniek & 63 & 26 & 11 \\
\hline Economie & 60 & 29 & 11 \\
\hline Gezondheidszorg & 68 & 25 & 7 \\
\hline BOL niveau 3 & 76 & 20 & 4 \\
\hline Landbouw & 68 & 25 & 7 \\
\hline Techniek & 83 & 17 & 0 \\
\hline Economie & 70 & 23 & 7 \\
\hline Gezondheidszorg & 77 & 20 & 3 \\
\hline Gedrag en maatschappij & 79 & 17 & 4 \\
\hline BOL niveau 4 & 79 & 18 & 3 \\
\hline Landbouw & 75 & 21 & 4 \\
\hline Techniek & 82 & 16 & 2 \\
\hline Economie & 73 & 23 & 4 \\
\hline Gezondheidszorg & 82 & 18 & 1 \\
\hline Gedrag en maatschappij & 82 & 15 & 3 \\
\hline $\mathrm{BBL}$ & 77 & 15 & 8 \\
\hline BBL niveau 1 & 61 & 10 & 29 \\
\hline BBL niveau 2 & 76 & 15 & 9 \\
\hline Landbouw & 70 & 19 & 11 \\
\hline Techniek & 77 & 13 & 9 \\
\hline Economie & 74 & 18 & 8 \\
\hline Gezondheidszorg & 76 & 15 & 9 \\
\hline BBL niveau 3 & 82 & 13 & 5 \\
\hline Landbouw & 86 & 9 & 6 \\
\hline Techniek & 84 & 12 & 4 \\
\hline Economie & 67 & 21 & 12 \\
\hline Gezondheidszorg & 84 & 12 & 4 \\
\hline Gedrag en maatschappij & 85 & 13 & 2 \\
\hline
\end{tabular}


Tabel A10.1

Opleiding achteraf opnieuw kiezen: intrede op de arbeidsmarkt

\begin{tabular}{|c|c|c|c|}
\hline Opleidingssector & $\begin{array}{r}\text { zelfde } \\
\text { opleiding } \\
\%\end{array}$ & $\begin{array}{r}\text { andere } \\
\text { opleiding } \\
\%\end{array}$ & $\begin{array}{r}\text { geen } \\
\text { opleiding } \\
\%\end{array}$ \\
\hline
\end{tabular}

\begin{tabular}{|c|c|c|c|}
\hline BBL niveau 4 & 80 & 17 & 3 \\
\hline Techniek & 89 & 8 & 4 \\
\hline Economie & 65 & 29 & 6 \\
\hline Gezondheidszorg & 82 & 16 & 2 \\
\hline Gedrag en maatschappij & 82 & 17 & 1 \\
\hline HBO & 81 & 19 & 1 \\
\hline Landbouw & 79 & 21 & 1 \\
\hline Onderwijs & 87 & 12 & 1 \\
\hline Techniek & 82 & 17 & 1 \\
\hline Economie & 75 & 24 & 0 \\
\hline Gezondheidszorg & 87 & 13 & 0 \\
\hline Gedrag en maatschappij & 80 & 19 & 0 \\
\hline Taal en cultuur & 84 & 14 & 2 \\
\hline Wo & 83 & 16 & 1 \\
\hline Landbouw & 83 & 16 & 1 \\
\hline Techniek & 86 & 13 & 1 \\
\hline Economie & 85 & 14 & 1 \\
\hline Gezondheidszorg & 88 & 11 & 1 \\
\hline Gedrag en maatschappij & 81 & 18 & 1 \\
\hline Taal en cultuur & 75 & 25 & 1 \\
\hline Recht en openbare orde & 86 & 13 & 1 \\
\hline Natuurwetenschappen & 84 & 15 & 1 \\
\hline Totaal & 79 & 18 & 3 \\
\hline
\end{tabular}


Tabel A11.1

Aantallen en respons

\begin{tabular}{|c|c|c|c|c|}
\hline Opleidingssector & benaderde aantallen & responspercentage & ongewogen aantallen") & gewogen aantallen \\
\hline HAVO/VWO & 5.156 & 38 & 1.806 & 67.479 \\
\hline HAVO & 2.909 & 37 & 966 & 38.152 \\
\hline VW0 & 2.247 & 40 & 840 & 29.327 \\
\hline $\begin{array}{l}\text { VMBO } \\
\text { Naarleerweg }\end{array}$ & 10.604 & 35 & 3.789 & 98.246 \\
\hline Theoretisch & 3.421 & 42 & 1.347 & 41.274 \\
\hline Gemengd & 793 & 43 & 351 & 6.059 \\
\hline Kaderberoepsgericht & 2.795 & 35 & 1.021 & 27.811 \\
\hline Basisberoepsgericht & 3.595 & & 1.070 & 23.102 \\
\hline Naar sector & & & & \\
\hline Landbouw & 2.047 & 24 & 499 & 5.768 \\
\hline Techniek & 1.855 & 30 & 585 & 14.906 \\
\hline Economie & 1.436 & 32 & 520 & 17.580 \\
\hline Gezondheidszorg & 1.845 & 44 & 838 & 18.718 \\
\hline $\mathrm{BOL}$ & 20.254 & 31 & 5.818 & 75.639 \\
\hline BoL niveau 1 & 1.283 & 20 & 213 & 6.616 \\
\hline BOL niveau 2 & 3.482 & 24 & 748 & 18.842 \\
\hline Landbouw & 143 & 26 & 37 & 527 \\
\hline Techniek & 885 & 21 & 162 & 4.434 \\
\hline Economie & 1.610 & 23 & 339 & 8.331 \\
\hline Gezondheidszorg & 841 & 29 & 210 & 5.550 \\
\hline BOL niveau 3 & 3.543 & 33 & 1.050 & 13.640 \\
\hline Landbouw & 244 & 45 & 110 & 687 \\
\hline Techniek & 321 & 25 & 74 & 1.146 \\
\hline Economie & 1.292 & 27 & 308 & 4.224 \\
\hline Gezondheidszorg & 723 & 37 & 237 & 3.121 \\
\hline Gedrag en maatschappij & 963 & 37 & 321 & 4.462 \\
\hline BOL niveau 4 & 11.946 & 33 & 3.807 & 36.541 \\
\hline Landbouw & 467 & 44 & 205 & 1.570 \\
\hline Techniek & 2.926 & 32 & 903 & 9.057 \\
\hline Economie & 4.505 & 28 & 1.216 & 11.298 \\
\hline Gezondheidszorg & 1.412 & 40 & 546 & 5.161 \\
\hline Gedrag en maatschappij & 2.636 & 37 & 937 & 9.455 \\
\hline BBL & 7.644 & 30 & 2.183 & 44.710 \\
\hline BBL niveau 1 & 598 & 24 & 137 & 3.968 \\
\hline BBL niveau 2 & 2.930 & 26 & 715 & 17.913 \\
\hline Landbouw & 248 & 29 & 72 & 970 \\
\hline Techniek & 1.382 & 22 & 294 & 8.342 \\
\hline Economie & 960 & 25 & 227 & 5.573 \\
\hline Gezondheidszorg & 340 & 38 & 122 & 3.029 \\
\hline BBL niveau 3 & 2.671 & 31 & 790 & 15.115 \\
\hline Landbouw & 164 & 27 & 45 & 537 \\
\hline Techniek & 1.034 & 29 & 282 & 5.660 \\
\hline Economie & 562 & 25 & 131 & 2.248 \\
\hline Gezondheidszorg & 692 & 40 & 266 & 5.382 \\
\hline Gedrag en maatschappij & 219 & 31 & 66 & 1.288 \\
\hline
\end{tabular}


Tabel A11.1

Aantallen en respons

$\begin{array}{lrrrr}\text { Opleidingssector } & \text { benaderde aantallen } & \text { responspercentage } & \text { ongewogen aantallen }{ }^{1)} & \text { gewogen aantallen } \\ \text { BBL niveau 4 } & & & & \\ \text { Landbouw } & 1.445 & 38 & 541 & 7.713 \\ \text { Techniek } & 35 & 46 & 16 & 165 \\ \text { Economie } & 332 & 34 & 109 & 1.755 \\ \text { Gezondheidszorg } & 334 & 31 & 105 & 1.490 \\ \text { Gedrag en maatschappij } & 398 & 45 & 175 & 2.428 \\ & 344 & 40 & 136 & 1.876 \\ \text { HBO } & & & & \\ \text { Landbouw } & 37.085 & 38 & 13.258 & 42.740 \\ \text { Onderwijs } & 1.285 & 44 & 532 & 1.581 \\ \text { Techniek } & 5.730 & 37 & 1.965 & 6.374 \\ \text { Economie } & 6.472 & 40 & 2.396 & 8.443 \\ \text { Gezondheidszorg } & 13.777 & 35 & 4.513 & 14.843 \\ \text { Gedrag en maatschappij } & 2.959 & 43 & 1.234 & 3.582 \\ \text { Taal en cultuur } & 4.143 & 42 & 1.668 & 5.216 \\ & 2.719 & 39 & 950 & 2.701 \\ \text { W0 }{ }^{2)} & & & & \\ \text { Landbouw } & 22.930 & 40 & 9.988 & 28.841 \\ \text { Techniek } & 961 & 52 & 467 & 1.348 \\ \text { Economie } & 2.572 & 48 & 1.376 & 3.973 \\ \text { Gezondheidszorg } & 4.387 & 33 & 1.593 & 4.600 \\ \text { Gedrag en maatschappij } & 2.774 & 45 & 1.340 & 3.869 \\ \text { Taal en cultuur } & 5.386 & 42 & 2.551 & 7.366 \\ \text { Recht en openbare orde } & 2.811 & 3.158 & 3.344 \\ \text { Naturwetenschappen } & 2.438 & 33 & 2.466 \\ & 1.601 & 39 & 649 & 1.874 \\ \text { Totaal } & & & & 357.655\end{array}$

1) het aantal ingevulde vragenlijsten dat in het onderzoeksbestand is opgenomen.

${ }^{2)}$ exclusief de universiteiten van Nijmegen, Groningen en Twente. 